\title{
Natürliche Waldentwicklung unter dem Einfluss des Borkenkäfers im Nationalpark Berchtesgaden
}

\author{
Bestandesstruktur und Biodiversität \\ im Verlauf von Störung und Sukzession
}

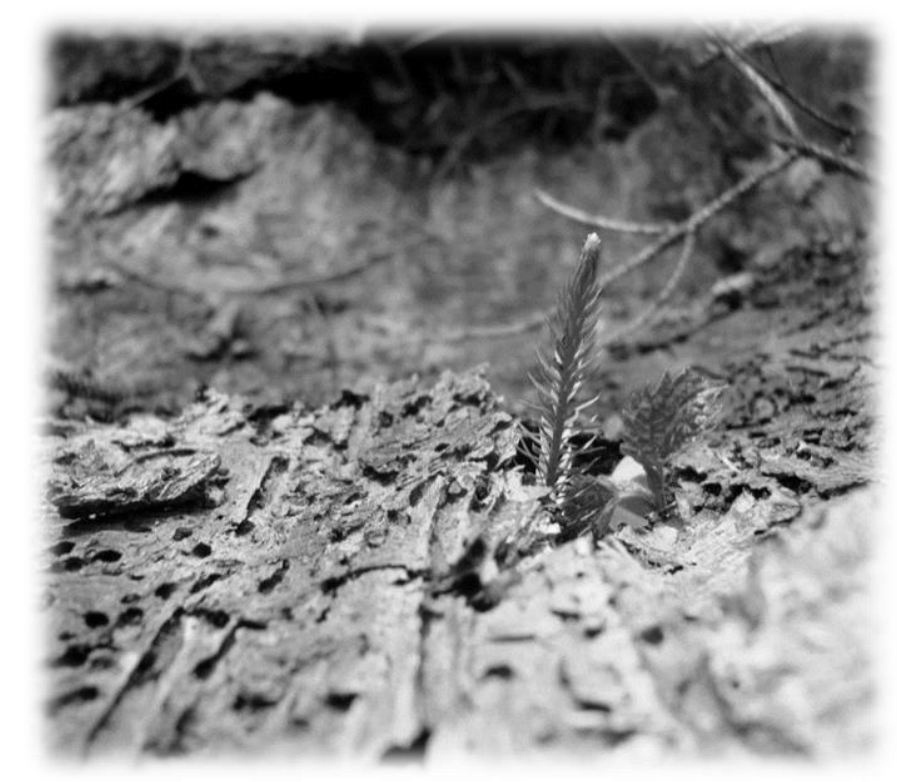

\begin{abstract}
Dissertation zur Erlangung des Doktorgrades

der Fakultät für Forstwissenschaften und Waldökologie der Georg-August-Universität Göttingen vorgelegt von
\end{abstract}

M.Sc.

Maria-Barbara Winter

geboren in Heilbronn 
Erstgutachter:

Prof. Dr. Christian Ammer

Abteilung Waldbau und Waldökologie der gemäßigten Zonen

Fakultät für Forstwissenschaften und Waldökologie

Georg-August Universität Göttingen

Zweitgutachter:

Prof. Dr. Jörg Müller

Ökologische Station Fabrikschleichach

Lehrstuhl für Tierökologie und Tropenbiologie

Biozentrum

Universität Würzburg

Tag der mündlichen Prüfung: 17.06.2016 
„Mut zur Wildnis, das ist auch der Mut zur Selbstbeherrschung.

Zum Schauen statt zum Tun.“

Hubert Weinzierl, 1998 



\section{Vorwort}

Aufgrund aktuellen Anlasses - verstärktem Borkenkäferbefall nach dem Wintersturm Kyrill (2007) und Unsicherheit über die weitere Entwicklung der Waldbestände im Nationalpark Berchtesgaden wurde diese Studie 2011 von der Nationalparkverwaltung Berchtesgaden initiiert und dankenswerter Weise vom Bayerischen Staatsministerium für Umwelt und Verbraucherschutz (StMUV) finanziert.

Den Hauptteil dieser kumulativen Arbeit bilden im Ergebnisteil zwei bereits publizierte und ein zur Veröffentlichung eingereichter Artikel. Diese gehen den Fragen nach, welche Standortveränderungen sich nach Absterben der Fichtenaltbestände durch den Borkenkäferbefall in den Waldbeständen ergeben und welchen Einfluss diese Veränderungen auf die weitere Waldentwicklung - Verjüngung, Artenzusammensetzung und Artenvielfalt von Gefäßpflanzen, Arthropoden, Mollusken und totholzbesiedelnden Pilzen - ausüben. Der Ergebnisteil wird durch zwei weitere Teilaspekte ergänzt, die nicht in den Publikationen integriert sind: einer Untersuchung zum Einfluss der Flächenausdehnung des Borkenkäferbefalls auf die anschließende Verjüngung und eine Analyse zum Einfluss von Flächenräumung und unterstützender Pflanzung auf Artenvielfalt und Verjüngung im Maßnahmenbereich Borkenkäferbekämpfung des Nationalparks. Die beiden Teilaspekte wurden in geringerer Intensität bearbeitet als die Hauptfragen und ermöglichen daher nur einen Einblick, aber keine abschließende Bewertung dieser Themen.

Dem Ergebnisteil ist eine Einführung in die Thematik und das Untersuchungsgebiet, sowie eine Übersicht über die Methoden der Studie vorangestellt. Abschließend erfolgt in der Diskussion eine Zusammenführung und Erörterung der einzelnen Ergebnisse. Die Artikel im Ergebnisteil sind in Englisch verfasst, aber um deutsche Übersetzungen von Zusammenfassung, Tabellenüberschriften und Abbildungsunterschriften ergänzt. In gleicher Weise sind die Tabellenüberschriften und Abbildungsunterschriften im deutschsprachigen Teil um die englischen Übersetzungen ergänzt. Für das Verständnis relevant erscheinende englische Fachbegriffe werden im deutschen Text (kursiv) erwähnt. 


\section{Inhalt}

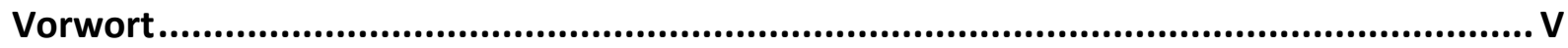

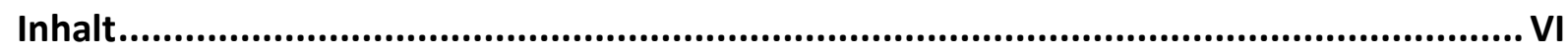

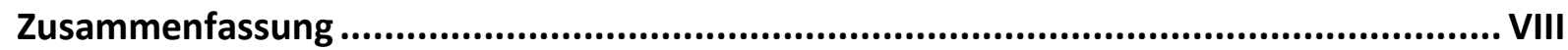

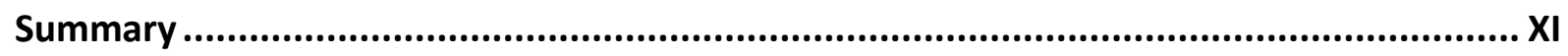

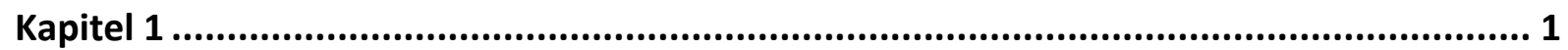

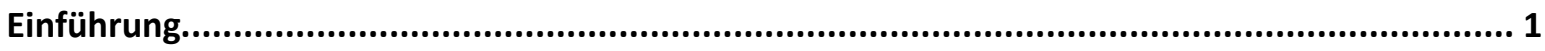

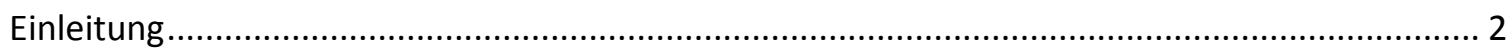

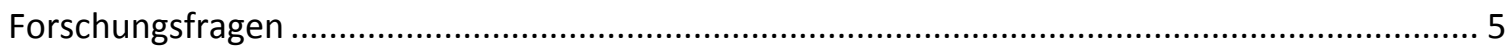

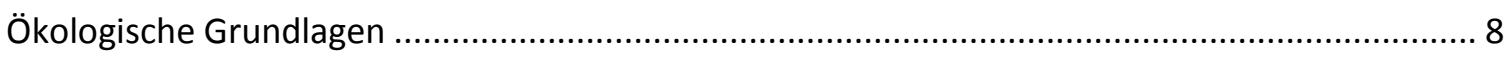

Untersuchungsgebiet Nationalpark Berchtesgaden .......................................................... 13

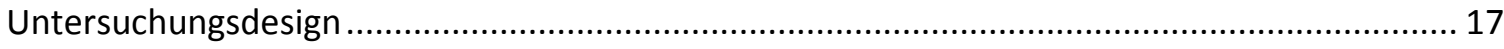

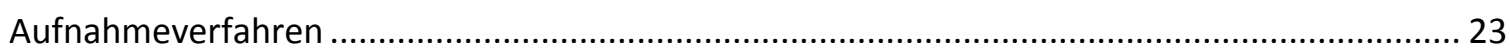

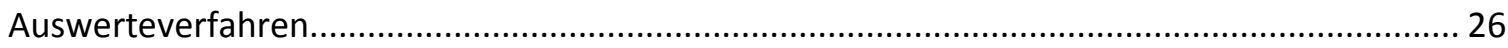

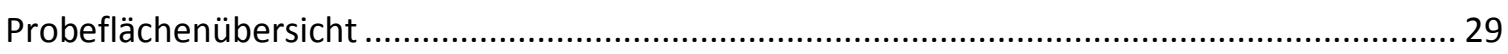

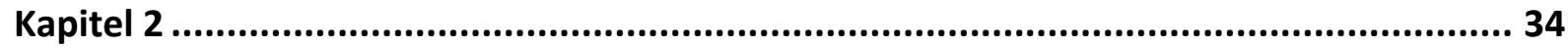

Regeneration dynamics and resilience of unmanaged mountain forests in the Northern Limestone Alps following bark beetle-induced spruce dieback ................................................ 34

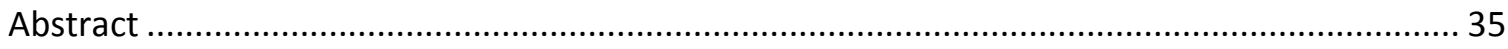

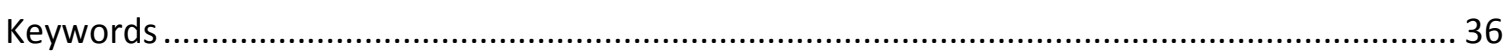

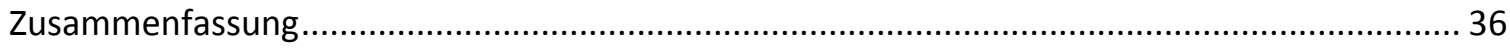

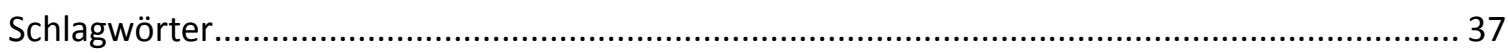

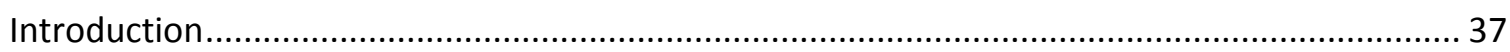

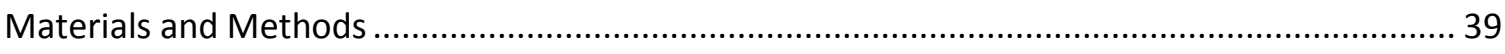

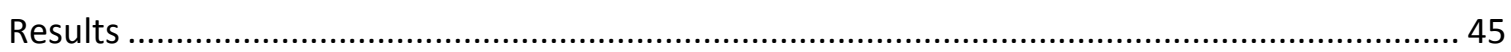

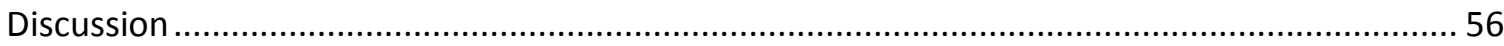

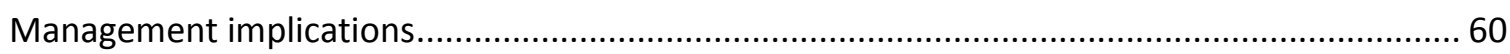

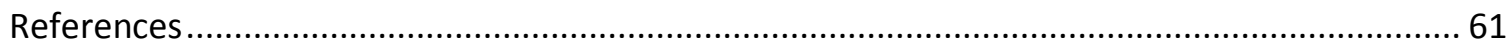

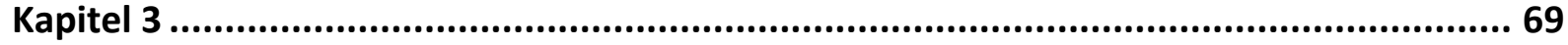

Multi-taxon alpha diversity following severe bark beetle disturbance: Evaluating multi-decade persistence of a diverse early-seral phase...............................................................................69 69

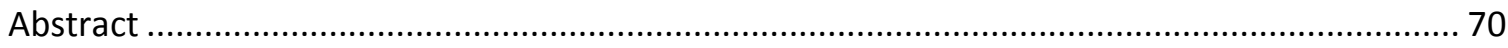

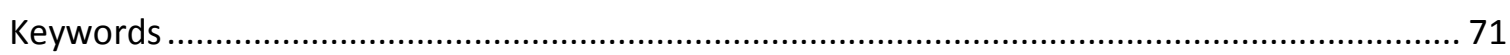

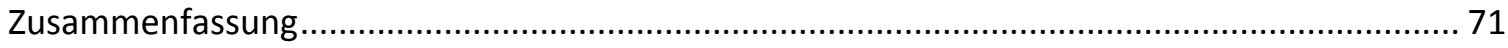

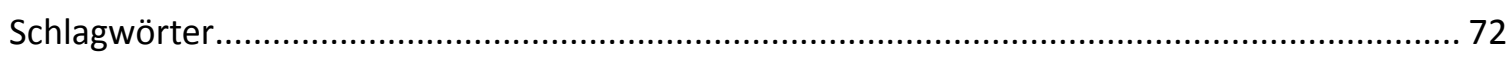

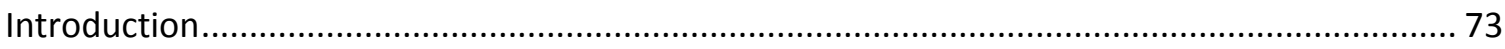

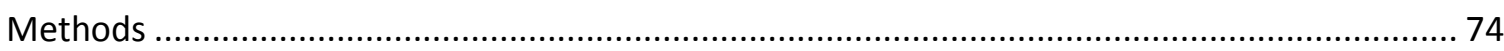

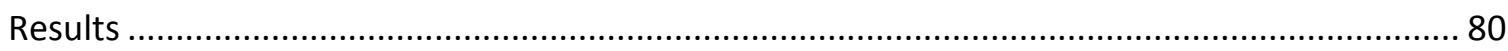

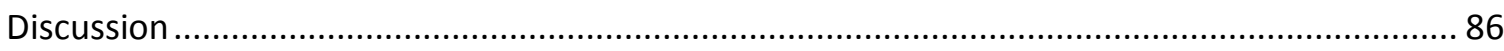

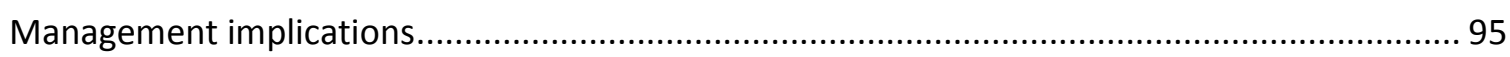

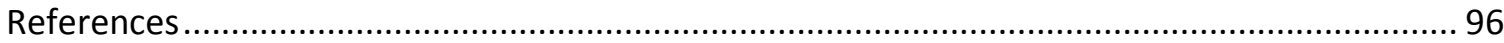




\section{Kapitel 4}

High spatial heterogeneity of early-seral forest ecosystems affects diversity of producers, consumers and decomposers differently

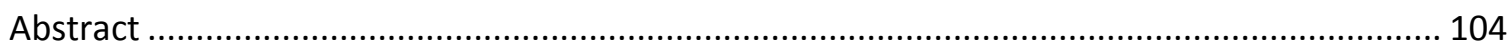

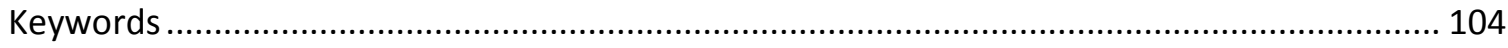

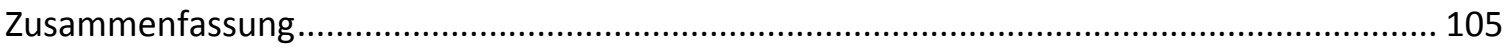

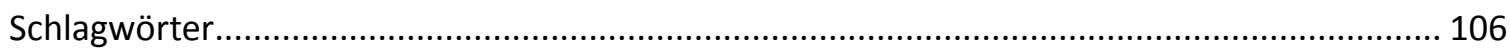

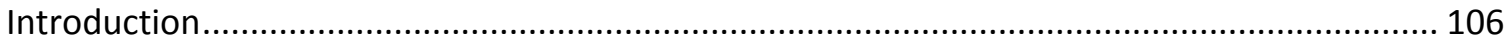

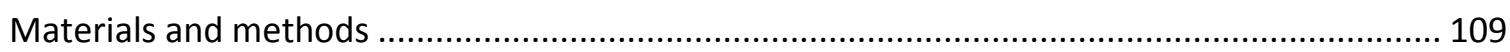

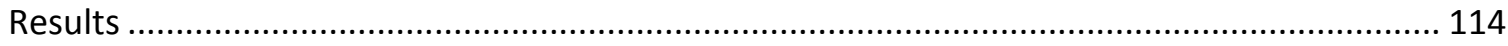

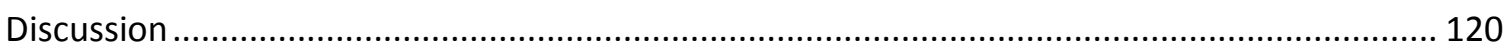

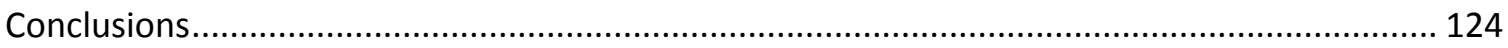

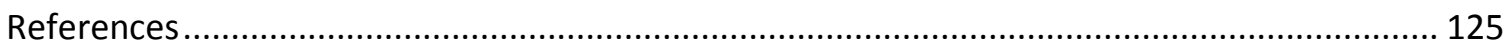

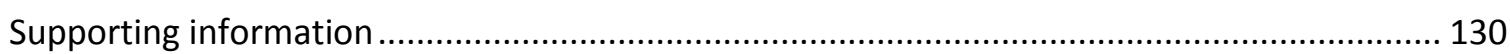

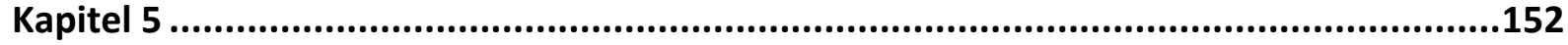

Einfluss von Befallsflächengröße, Flächenräumung und Pflanzung auf Verjüngung und

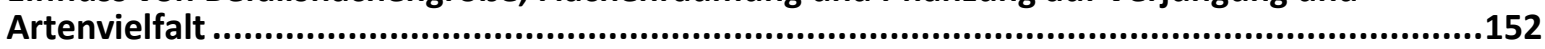

Einfluss der Flächenausdehnung des Borkenkäferbefalls auf die Verjüngung ........................... 153

Einfluss von Flächenräumung und Pflanzung auf Verjüngung und Artenvielfalt........................ 159

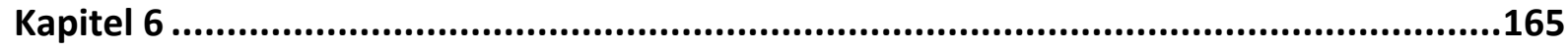

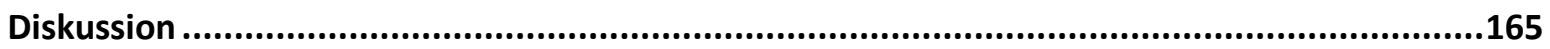

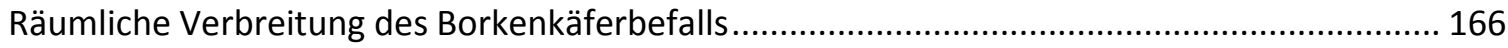

Veränderung der Standort- und Bestandesverhältnisse ......................................................... 167

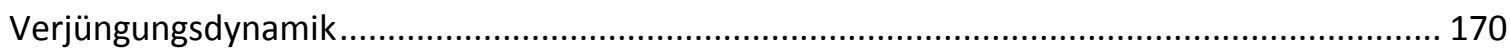

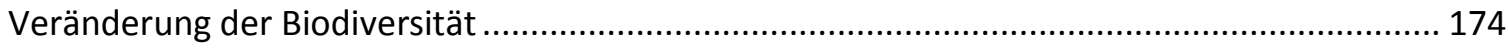

Einfluss von Flächenräumung und unterstützender Pflanzung............................................... 179

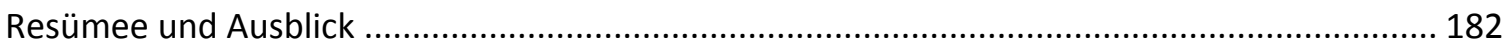

Schlussfolgerungen für die forstliche und naturschutzfachliche Praxis..................................... 184

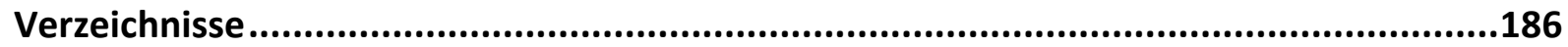

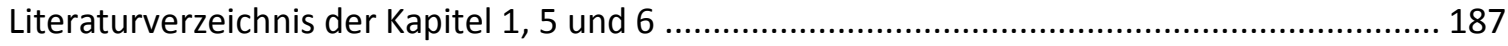

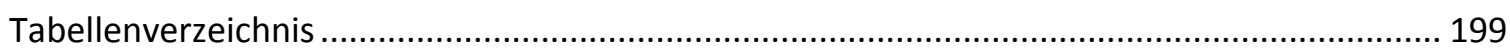

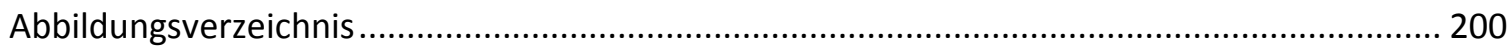

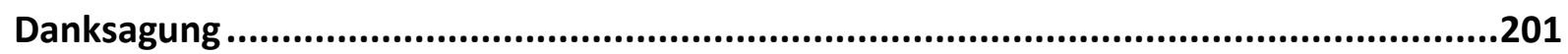

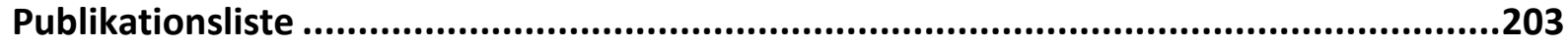

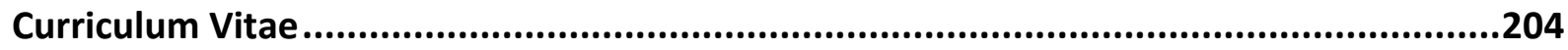




\section{Zusammenfassung}

Störungen sind ein integraler Bestandteil von Waldökosystemen. Von einzelbaumweiser Seneszenz bis hin zu großflächigem Windwurf, Waldbrand oder Insektenbefall prägen sie natürlicherweise Artenzusammensetzung, Generationswechsel und Verjüngungsprozesse von Waldbeständen. Aufgrund wirtschaftsbedingt hoher Anteile an sekundären reinen Nadelholzbeständen und sich ändernden klimatischen Bedingungen ist der Einfluss großflächiger Störungen im letzten Jahrhundert in Mitteleuropa angestiegen und wird vermutlich auch zukünftig weiter an Bedeutung gewinnen. Das ökosystemare Verständnis über die Wirkung dieser Störungsereignisse auf Artenzusammensetzung und natürliche Waldentwicklung ist wesentlich für eine nachhaltige Waldbewirtschaftung. Im Wirtschaftswald kann der Einfluss natürlicher Störungen aufgrund stetiger Einflussnahme durch Räumung, Pflanzung und Durchforstungen schwerlich untersucht werden. Großflächige Schutzgebiete mit dem Prozessschutz dienenden unbewirtschafteten Kernzonen bieten hingegen diese Möglichkeit.

Am Beispiel des Nationalparks Berchtesgaden im südlichen Oberbayern (Deutschland) wurde daher exemplarisch für die Nördlichen Kalkalpen die natürliche Waldentwicklung unter dem Einfluss des Borkenkäfers und die Veränderungen von Bestandesstrukturen und Biodiversität im Verlauf von Störung und Sukzession untersucht. Durch den großen Holzbedarf der regional ansässigen Salinenindustrie ab dem 16. Jahrhundert, der jahrhundertelangen Kahlschlagswirtschaft und den hohen Wilddichten im Bayerischen Hofjagdgebiet wurden die natürlicherweise in den montane Lagen stockenden Bergmischwälder aus Europäischer Buche, Weißtanne und Gemeiner Fichte in überwiegend reine, sekundäre Fichtenwälder umgewandelt. Seit Einrichtung des Nationalparks Berchtesgaden 1978 kam es besonders nach den Winterstürmen Vivian/Wiebcke 1990 und Kyrill 2007 zu stärkerem Borkenkäferbefall. Luftbildauswertungen belegen ein zerstreutes und eher kleinflächiges Befallsgeschehen außerhalb des Maßnahmenbereichs Borkenkäferbekämpfung. Mittlere Befallsflächengrößen lagen bei 0,07 ha (1990-1997) und 0,29 ha (2007-2012); die Gesamtbefallsflächen betrugen 30 ha (1990-1997) und 260 ha (2007-2012). Mit der Methodik einer unechten Zeitreihe konnte auf 140 Probeflächen die Entwicklung unbefallener Fichtenaltbestände über das beginnende frühsukzessionale Stadium (1-5 Jahre nach Borkenkäferbefall) hin zum fortgeschrittenen frühsukzessionalen Stadium (17-25 Jahre nach Borkenkäferbefall) von montaner bis subalpiner Höhenstufe in sonn- und schattseitigen Lagen erfasst werden.

Das Absterben der Fichtenaltbestände durch den Borkenkäferbefall führte zu einer signifikanten Reduktion der Bestandesvolumina und der Kronenüberschirmung auf den Befallsflächen bei gleichzeitig massiver Zunahme an stehendem Totholz. Erhebliche Anteile des stehenden Totholzes 
brachen bei fortschreitender Zersetzung im Verlauf der untersuchten etwa 20-jährigen Sukzession zusammen. Humusabbau und signifikante Veränderungen des Mesoklimas durch die Störung waren nicht nachzuweisen. Die durch das Absterben des Kronendachs erhöhten Anteile an direkter Strahlung am Waldboden führten zu einer zunehmenden Deckung und Höhe der Bodenvegetation.

Trotz der verstärkten Konkurrenzsituation mit der Bodenvegetation kam es, besonders in montaner Lage, zu einer zügigen Verjüngung der Befallsflächen mit Jungwuchsdichten von im Median rund 5.000 Pflanzen $>50 \mathrm{~cm}$ Höhe und weiteren etwa 5.000 Pflanzen $<50 \mathrm{~cm}$ Höhe pro Hektar, zwei Jahrzehnte nach dem Borkenkäferbefall. Hochmontan war diese Entwicklung verzögert zu beobachten. Hier nahm Bedeutung des Totholzes als Keim- und Wuchssubstrat mit zunehmender Zersetzung zu. Der Jungwuchs wurde von Gemeiner Fichte, Bergahorn und Vogelbeere dominiert. Die natürlichen Hauptbaumarten des Bergmischwaldes - Europäische Buche und Weißtanne - fehlten jedoch aufgrund der historischen Bewirtschaftung und mangelnden Samenbäumen auch im Jungwuchs weitgehend. Die Störung führte unter anderem durch das räumlich unregelmäßige Aufkommen des Jungwuchses zu einer erhöhten strukturellen Heterogenität auf Bestandes- und Landschaftsebene. Entgegen der Erwartungen spielte die Vorausverjüngung für die Verjüngung nach dem Störungsereignis eine vernachlässigbar geringe Rolle. Mehr als 90 \% der Jungwuchsindividuen waren nach dem Störungsereignis gekeimt und bestätigten damit eine große Resilienz der Bergwälder nach mittelgroßen Störungsereignissen unter der Voraussetzung angepasster Schalenwildbestände.

Bei den untersuchten epigäischen Artengruppen waren keine Veränderungen (Käfer, Spinnentiere, Mollusken), bzw. ein Rückgang der Artenvielfalt (Springschwänze) aufgrund fehlender Streunachlieferung nach der Störung zu beobachten. Die licht-, nährstoff- und totholzbedürftigen Arten profitierten hingegen von den temporären Lückenbedingungen und reagierten überwiegend mit einem Anstieg der Artenvielfalt im Verlauf der Sukzession. Dieser Anstieg war auch zwei Jahrzehnte nach dem Störungsereignis trotz zunehmender Verjüngungsdichten noch zu beobachten. Dies verdeutlicht die Relevanz von sich langsam schließenden Bestandesöffnungen für eine vollständige Entwicklung der Biodiversität heliophiler Artengruppen in Waldökosystemen. Durch das Mosaik verschiedener, kleinräumig verbreiteter Sukzessionsstadien auf Landschaftsebene zeigten besonders die totholzbesiedelnden Pilze und Käfer eine hohe Gamma-Diversität im Gebiet. Die Artengemeinschaften der Gefäßpflanzen ähnelten sich hingegen stark in ihrer Artenzusammensetzung in den drei untersuchten Sukzessionsstadien und zeichneten sich mehr durch eine Verschiebung der Dominanzverhältnisse aus. 
Räumung und Pflanzung auf Befallsflächen innerhalb des Maßnahmenbereichs Borkenkäferbekämpfung führten im Vergleich zu den unbehandelten Befallsflächen nicht zu einer Erhöhung der Jungwuchsdichten im beginnenden frühsukzessionalen Stadium, aber zu einer Steigerung der Anteile an Weißtanne und Europäischer Buche im Jungwuchs. Mollusken, Wanzen und bestäubende Käferarten reagierten auf die tendenziell höheren Strahlungsmengen am Waldboden und zeigten höhere Artenzahlen auf den geräumten Flächen. Zeitgleich veränderte die Räumung des befallenen Totholzes die Artenzusammensetzung vieler der untersuchten Artengruppen und reduzierte die Artenvielfalt der xylobionten Käfer.

Der forstlichen und naturschutzfachlichen Praxis wird aus den Ergebnissen dieser Untersuchung heraus empfohlen, die durch natürlichen Störungen entstandenen Lücken und Strukturen zu nutzen, um den Erhalt von licht-, nährstoff- und totholzbedürftigen Artengruppen zu fördern und, soweit aus Gründen des Lawinen- und Forstschutzes möglich, auf Räumung und direkte Bepflanzung der Flächen zu verzichten. Wo es das Ziel ist, die natürliche Baumartenzusammensetzung der Bergmischwälder kurzfristig wieder herzustellen, müssen Buche und Tanne bei einem Mangel an Samenbäumen künstlich eingebracht werden. Ansonsten weisen die im Gebiet stockenden Bergwälder unter der Voraussetzung angepasster Wildbestände bei mittelgroßen Störungsereignissen eine große Resilienz auf und lassen ein Schließen der Bestandeslücken durch Naturverjüngung erwarten. 


\section{Summary}

Disturbances are an integral part of forest ecosystems. Integrating single-tree dynamics to large-scale disturbances as windthrows, fire or insect calamities, disturbances influence natural species composition and regeneration processes of forest stands. Management-related high shares of pure secondary coniferous stands and changing climatic conditions have increased the impact of largescale disturbances over the last century and it is likely that they are further going to increase in the future. Ecological knowledge about the impact of these disturbances on species composition and natural forest succession is essential for a sustainable forest management. Due to steady interventions with salvage-logging, planting and thinning activities, natural dynamics can hardly be studied in managed forests. However, large strictly protected areas enable such investigations.

Therefore, natural forest succession following bark beetle-induced spruce dieback and the related changes in stand structure and biodiversity were studied in the Berchtesgaden National Park (Germany) in the Northern Limestone Alps. Centuries of intensive timber extraction, mainly due to salt mining, and intentionally high ungulate populations heavily altered the forest structures and species composition of the Berchtesgaden National Park from natural mixed mountain forests dominated by European beech, silver fir and Norway spruce towards homogenous stands consisting purely or predominantly of Norway spruce. Following the establishment of the national park in 1978, severe bark beetle infestations occurred especially after the winter storms Vivian/Wiebcke in 1990 and Kyrill in 2007. Evaluations of aerial photographs revealed a scattered and rather small-scale development of the bark beetle infestations. Mean gap sizes comprised 0.07 ha (1990-1997) and 0.29 ha (2007-2012) and total infestation areas covered 30 ha (1990-1997) and 260 ha (2007-2012). Applying a chronosequence of 140 study plots of undisturbed secondary spruce stands (mature stage), stands affected by bark beetles within the last five years (initial early-seral stage) and stands infested in the 1990s (advanced early-seral stage) forest succession could be surveyed in montane to subalpine altitudinal zones, on south- and north-facing slopes.

The bark beetle-induced dieback of the mature spruce stands caused a significant reduction of stand volumes and crown cover, but initiated a huge emergence of standing deadwood. Large shares of the standing deadwood broke down due to decomposition during the first two decades of succession. Humus degradation and significant changes in mesoclimatic conditions could not be detected. The significantly increased shares of direct radiation at the forest floor induced by the spruce dieback, increased cover and height of the ground vegetation. 
Albeit the intensified competition with the ground vegetation, the gaps got regenerated rather fast. Around 5.000 regeneration individuals (> $50 \mathrm{~cm}$ height) could be found in median per hectare in the montane zone two decades after the bark beetle infestation. This development was slightly protracted in high montane zones, where the importance of deadwood as growing substrate increased with altitude and decay stage. Natural regeneration was dominated by Norway spruce, sycamore maple and rowan. European beech and silver fir would naturally dominate the mixed mountain forests, but where found in very little shares as seed trees and as regeneration individuals in this study, due to historical forest management. The disturbance and the scattered patterns of the post-disturbance regeneration initiated an increase of structural heterogeneity on stand and landscape level. The importance of advance regeneration for the regeneration process was almost negligible. Contrary to the expectations, more than $90 \%$ of the seedlings did germinate after the disturbance event. This indicates a high resilience of the mountain forests after medium-scale disturbance, if present ungulate densities enable the survival of the natural regeneration.

The studied epigaic species groups showed no changes (Coleoptera, Arachnida, Mollusca) as well as decreasing species densities (Collembola) due to missing litter supply after the disturbance. Contrary, the light, nutrient and dead wood dependent species did profit from the temporary gap conditions and revealed a significant increase in species densities during succession. The findings suggest that in unmanaged forests after bark beetle attack, a structurally complex phase prior to tree canopy closure can last several decades, and that many aspects of early-seral biodiversity and ecosystem function only fully develop given this extended time period. The mosaic of the different small-scale successional stages revealed a high gamma diversity, especially for wood-inhabiting fungi and saproxylic beetles. The species compositions of vascular plants did not vary significantly among the successional stages on landscape scale. Differences among the stages got rather visible as shifts in species dominances.

Salvage-logging and planting in the infested stands of the bark beetle management zone did not lead to higher regeneration densities than in unmanaged stands during the initial early-seral stage. However, the planting activities increased the shares of European beech and silver fir in the managed parts of the national park. Mollusks, true bugs and pollinating beetle species showed a positive response on the slightly higher radiation amounts in the salvage-logged gaps and revealed higher species densities on these sites. At the same time, the logging changed the species composition of many species groups and significantly decreased the species densities of the saproxylic beetles inside the bark beetles management zone. 
Where management of moutain forests includes objectives for sustaining biodiversity, accommodating the protracted early-seral stage is important to supporting the full range of organisms and functions associated with canopy-opening disturbances. European beech and silver fir need to be planted in managed forests, where involvement of these species is of prime importance and seed trees are missing. However, under comparable post-disturbance conditions, the high resilience of the mountain forests is expected to lead to fair natural regeneration densities, if ungulates are managed accordingly. 


\title{
Kapitel 1
}

\author{
Einführung
}

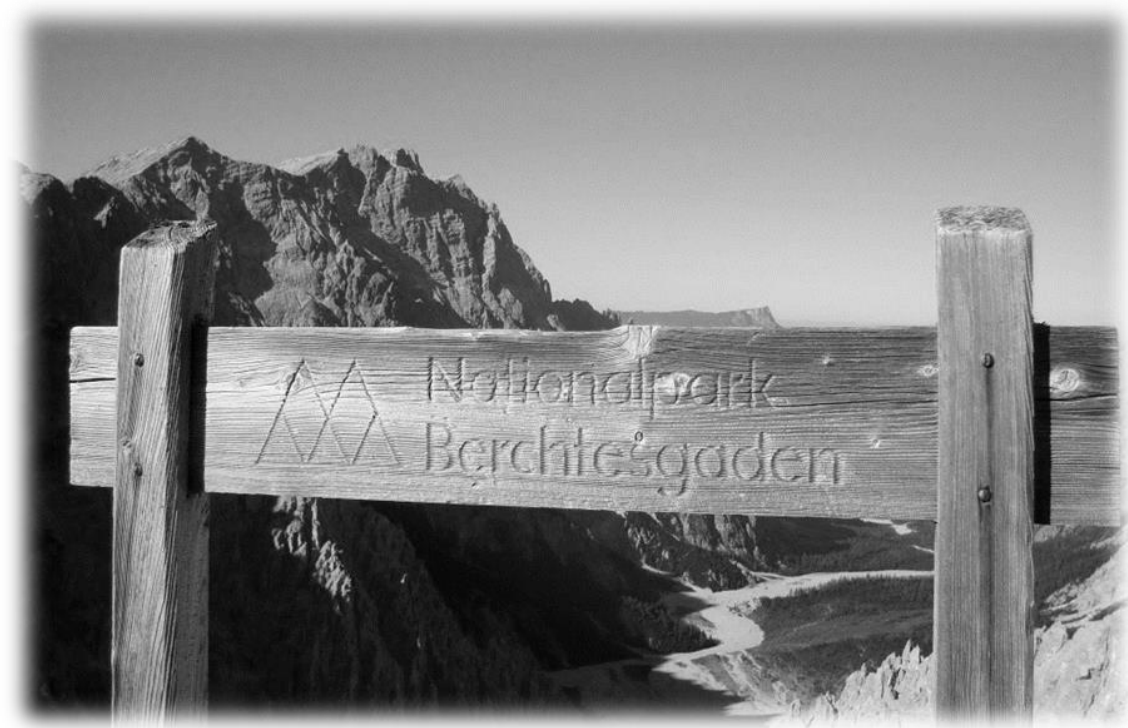

Der Nationalpark Berchtesgaden erstreckt sich von der submontanen zur alpinen Höhenstufe und ist durch eine Vielzahl verschiedener Vegetationseinheiten geprägt (Foto: M.B. Winter). 


\section{Einleitung}

Ein integraler Bestandteil von Waldökosystemen sind natürliche Störungen wie Stürme, Insektenbefall oder Feuer (Attiwill 1994, Franklin et al. 2002, Ellenberg und Leuschner 2010), deren Einfluss im letzten Jahrhundert jedoch zunehmend an Bedeutung gewonnen hat (Schelhaas et al. 2003, Seidl et al. 2014, Kärvemo et al. 2014). Zwischen 1950 und 2000 führte in den europäischen Wäldern allein der Befall durch Borkenkäfer (Curculionidae: Scolytinae, hauptsächlich Großer Buchdrucker (Ips typographus L.) und Kupferstecher (Pitogenes chalcographus L.)) zu einem Anfall von jährlich etwa 2,9 Millionen $\mathrm{m}^{3}$ Totholz (Schelhaas et al. 2003). Bewirtschaftungsbedingte Waldzustände und sich ändernde klimatische Bedingungen werden den Einfluss natürlicher Störungen auf die Wälder in den kommenden Jahrzehnten sehr wahrscheinlich noch verstärken (Seidl et al. 2011, 2014). Im 19. und 20. Jahrhundert wurden viele der über weite Teile Europas natürlicherweise stockenden Mischwälder in überwiegend reine Fichtenwälder überführt. Auch in den Alpen haben die Jahrhunderte intensivster Holznutzung (z.B. für die Salinenindustrie) und die hohen Wilddichten die Waldstrukturen und Baumartenzusammensetzung massiv zu Gunsten der Gemeinen Fichte (Picea abies (L.) Karst) verändert (Knott et al. 1988). Die Mehrzahl dieser Bestände sind nun weitaus instabiler gegenüber Störungen durch Sturm oder Insektenbefall als es die Wälder waren, die ersetzt wurden (Seidl et al. 2011). Dies wird in zweifacher Weise durch den Klimawandel verstärkt: Erstens erschließen sich durch die Erwärmung für Borkenkäferpopulationen bislang ungeeignete Habitate in höheren geographischen Breiten und Höhenlagen (Krehan und Steyrer 2006, Seidl et al. 2009). Und zweitens führen die durch den Klimawandel in Häufigkeit und Intensität zunehmenden Extremwetterereignisse wie Stürme oder Dürreperioden (Frich et al. 2002, Beniston et al. 2007) zu geschädigten oder geschwächten und damit bei Borkenkäferbefall bereits prädisponierten Beständen (Overbeck und Schmidt 2012, Hartl-Meier et al. 2014).

Dennoch haben natürliche Störungen bereits im Laufe der Evolution die wesentlichen Prozesse von Waldökosystemen mit beeinflusst, und die Mehrzahl der heute in Wäldern vorzufindenden Arten entwickelte sich durch Anpassung an natürliche Störungsregime der Vergangenheit (Sousa 1984, Bengtsson et al. 2000). Nach der Habitat-Heterogenitäts-Hypothese (habitat heterogeneity hypothesis) ist Artenvielfalt positiv mit Habitatkomplexität korreliert (Tews et al. 2004, McElhinny et al. 2005, Stein et al. 2014). Damit lässt sich durch die in vielen Fällen große strukturelle Heterogenität von störungsbeeinflussten frühsukzessionalen Waldbeständen (Swanson et al. 2011, Donato et al. 2012) auch einen Anstieg der Artenvielfalt nach Störungen erwarten (Bouget und Duelli 2004). Großflächiger Borkenkäferbefall führt durch das Absterben der Altbäume zu einer signifikanten Reduktion des Kronendaches und der lebenden Phytomasse und damit zu erhöhter Besonnung des Waldbodens, extremeren Temperaturen und Temperaturschwankungen, größerer Deckung und 
Höhe der Bodenvegetation und häufig zu beschleunigten Nährstoffflüssen im Boden (Sousa 1984, Roberts 2004, Swanson et al. 2011). Gleichzeitig entstehen große Mengen an stehendem Totholz (Donato et al. 2013). Bei unterbleibenden waldbaulichen Eingriffen durch Holzaufarbeitung oder Pflanzung lässt sich damit besonders für licht-, nährstoff- und totholzbedürftige Arten zumindest temporär eine Begünstigung erwarten (Müller et al. 2008, 2010). Die dieses frühsukzessionale Stadium prägenden Strukturmerkmale - horizontale und vertikale Bestandesheterogenität, große Mengen an stehendem dickem Totholz und das Nebeneinander von Schatt- und Lichtbaumarten weisen starke Parallelen zur Zerfallsphase alter Wälder auf (Remmert 1991). Wie lange sich eine solche temporär struktur- und artenreiche Phase nach natürlichen Störungen halten wird, und ob sie die Bestandesstrukturen eventuell sogar über die frühsukzessionalen Stadien hinaus prägen wird, ist Gegenstand der aktuellen wissenschaftlichen Diskussion (Donato et al. 2012, Campbell und Donato 2014).

Viele der ökologischen Funktionen von Bergwäldern, wie Erosions- und Lawinenschutz, Kohlenstoffspeicherung und Holzproduktion sind an die Kontinuität stabiler Waldbestände gebunden (Otto 1994). Stabilität kann im Hinblick auf Störungen mit den Konzepten der Widerstandsfähigkeit (resistance) und der Erholungsfähigkeit oder Resilienz (resilience) von Beständen charakterisiert werden (Kräuchi et al. 2000, Brang 2001, Dorren et al. 2004). Unter Widerstandkraft wird dabei die Fähigkeit eines Bestandes verstanden, trotz des Einwirkens von Störungsfaktoren im Wesentlichen unverändert zu bestehen (Grimm und Wissel 1997), während Resilienz die Fähigkeit eines Bestandes beschreibt, sich nach einer Störung selbstständig wieder zum Ausgangzustand hin zu entwickeln (Dorren et al. 2004). Etliche Studien haben in den letzten Jahrzehnten Ideen entwickelt, um die Widerstandsfähigkeit von Bergwäldern gegen Störungen, wie Stürme, Insektenbefall oder Witterungsereignisse zu verbessern (z.B. Papaik und Canham 2006, Bruelheide und Luginbühl 2009, Höllerl 2009a). Da solche Konzepte in waldbaulich vernachlässigten, älteren sekundären Fichtenbeständen jedoch an ihre Grenzen stoßen, hat sich ein verstärktes Interesse am Verständnis der Resilienz europäischer Bergwaldökosysteme entwickelt (Dorren et al. 2004).

Erfolgreiche Naturverjüngung gilt als wesentlichster Bestandteil von Resilienz (Brang 2001). Zahlreiche Studien legen dabei nahe, dass eine erfolgreiche Naturverjüngung nach großflächigen Störungen - seien diese natürlich, wie bei Borkenkäferbefall, oder wirtschaftsbedingt im Falle intensiver Holzerntemaßnahmen - stark an das Vorhandensein von Vorausverjüngung (advance regeneration), d.h. bereits vor Absterben oder Entfernen des Altbestandes aufgekommener Jungwuchs, gebunden ist (Bauer 2002, Rammig et al. 2006, El Kateb et al. 2009, Wild et al. 2014, Zeppenfeld et al. 2015). Die durch das rasche Verschwinden des Altbestandes verursachten beschriebenen Strukturveränderungen (u.a. extremere Temperaturschwankungen und größere 
Dominanz der Bodenvegetation) können die erfolgreiche Naturverjüngung verhindern oder zumindest verzögern (Ammer 1996b, Brang et al. 2003, Ammer et al. 2011) und damit die Kontinuität wichtiger Waldökosystemfunktionen wie den Schutz gegen Naturgefahren beinträchtigen. Neben Samenverfügbarkeit und angepassten Wildbeständen ist speziell in Bergwäldern die Keimung und Etablierung vieler Baumarten zusätzlich an bestimmte Mikrostandorte und Substrate, wie dicke Humusauflagen und Totholzmoder, oder erhöhte Positionen gebunden (siehe Ammer 1998, Brang et al. 2003, Baier et al. 2007). Es ist zu erwarten, dass solchen Spezialstandorten unter den widrigeren Bedingungen der Störungsflächen noch größere Bedeutung für die Naturverjüngung beizumessen ist.

Urwälder, an denen sich der Effekt von Störungen auf Bestandesstrukturen, Verjüngung und Stabilität natürlicher Wälder beobachten ließe, sind in Mitteleuropa bis auf wenige und oft sehr kleinflächige Ausnahmen nicht mehr vorhanden (Ellenberg und Leuschner 2010). Selbst heute strikt geschützte Gebiete sind in Mitteleuropa überwiegend von intensiver anthropogener Nutzung und nicht selten von Übernutzung in der Vergangenheit geprägt (Pechmann 1932, Meister 1969, Knott et al. 1988, Wäldchen et al. 2011). Es hat sich aber gezeigt, dass sich Wälder in Prozessschutzgebieten unter bestimmten Bedingungen in ihren Strukturen und ihrer Baumartenzusammensetzung wieder ursprünglichen Ausgangsbeständen annähern können (Meyer 2013), und diese Entwicklung durch natürliche Störungen in manchen Fällen sogar beschleunigt werden kann (Müller et al. 2008). Die Zeitdauer dieses Prozesses und das Ausmaß der Entwicklung hin zum Ausgangszustand bezüglich Artenzusammensetzung und Struktur sind jedoch noch weitgehend unbekannt.

Auch wenn die Bestände der heutigen mitteleuropäischen Schutzgebiete eine lange Nutzungstradition aufweisen, bieten sie dennoch eine wertvolle Grundlage, um den Effekt des Nutzungsverzichts und die Entwicklung zur natürlichen Walddynamik wissenschaftlich zu beobachten. Darüber hinaus lassen Studien in ungenutzten, störungsbeeinflussten Bergwäldern Erkenntnisse für die forstliche Praxis erwarten. In vielen Fällen ist bei waldbaulichen Eingriffen zur Umwandlung reiner sekundärer Fichtenbestände in strukturiertere Mischbestände auch mit einer ökonomischen Rentabilität zu rechnen (Höllerl 2009b). Wo dies unter Umständen nicht der Fall ist, z.B. in abgelegenen und spärlich erschlossenen Gebieten, ist es wesentlich zu wissen, wie und wie weit erwünschte Änderungen in Artenzusammensetzung und Bestandesstruktur auch unter Ausnutzung natürlicher Prozesse erreicht werden können. Die außerhalb der mitteleuropäischen Alpen unter anderem in Nordamerika (u.a. Franklin et al. 2002, Turner 2010, Swanson et al. 2011, Donato et al. 2012, Campbell und Donato 2014), dem Harz (Keidel et al. 2008), dem Bayerischen Wald (u.a. Bauer 2002, Müller et al. 2008, Bässler et al. 2012, Lehnert et al. 2013, Beudert et al. 2015) und dem daran angrenzenden Böhmerwald in der Tschechischen Republik (Jonášová und Prach 2004, Svoboda und Pouska 2008, Jonášová et al. 2010) durchgeführten Untersuchungen verdeutlichen die 
Relevanz der Erkenntnisse für das Verständnis natürlicher Waldentwicklungsprozesse und dem Einfluss von Störungen auf die Biodiversität. In mitteleuropäischen Berg- und Schutzwäldern beziehen sich die bisherigen wissenschaftlichen Ergebnisse zur natürlichen Walddynamik nach großflächigen Störungsereignissen jedoch ausschließlich auf Windwurfflächen oder Untersuchungen einzelner Bestände (Kupferschmid Albisetti 2003, Puettmann und Ammer 2007, Priewasser 2013, Brang et al. 2015, Wohlgemuth und Kramer 2015).

\section{Forschungsfragen}

Diese Arbeit widmet sich darum der Untersuchung natürlicher Waldentwicklung nach Borkenkäferbefall in dem in den nördlichen Kalkalpen gelegenen Nationalpark Berchtesgaden. Anhand einer unechten Zeitreihe von unbefallenen Fichtenaltbeständen, über das beginnende frühsukzessionale Stadium (ca. 3 Jahre nach Borkenkäferbefall) hin zum fortgeschrittenen frühsukzessionalen Stadium (ca. 20 Jahre nach Borkenkäferbefall), wurden von der montanen zur subalpinen Höhenstufe auf 140 Probeflächen folgende Forschungsfragen untersucht:

I. Welche standortspezifischen Veränderungen ergeben sich durch den Borkenkäferbefall in den Waldbeständen?

Kapitel 2

II. Welchen Einfluss haben diese Veränderungen auf die Verjüngung und wie läuft diese ab?

Kapitel 2 und 4

III. Welche Konsequenzen ergeben sich durch die veränderten Standortverhältnisse für die Artenzusammensetzung und Artenvielfalt von verschiedenen Artengruppen von Pflanzen, Tieren und Pilzen?

Kapitel 3 und 4

IV. Welchen Einfluss hat die Flächenausdehnung des Borkenkäferbefalls auf die Verjüngung im beginnenden frühsukzessionalen Stadium?

Wie unterscheiden sich Standortbedingungen und Verjüngungssituation nach Borkenkäferbefall auf großen Befallsflächen (> 1 ha) im Vergleich zu den kleineren Befallsflächen $(<1$ ha)? Und welche Unterschiede sind zwischen den einzelnen Positionen (Nord-, Ost-, Süd-, Westrand, Mittelbereich) innerhalb der großen Befallsflächen zu erkennen?

Kapitel 5

V. Welchen Einfluss üben Flächenräumung und unterstützende Pflanzung im Maßnahmenbereich Borkenkäferbekämpfung auf Verjüngung und Artenvielfalt im beginnenden frühsukzessionalen Stadium aus?

Kapitel 5 
Die Fragen IV und V stellen lediglich Teilaspekte der Gesamtstudie dar, die aufgrund der örtlichen Begebenheiten (Vorhandensein nur einzelner vergleichbarer Befallsflächen im Maßnahmenbereich Borkenkäferbekämpfung und nur weniger Befallsflächen $>1$ ha) mit deutlich geringerer Gewichtung untersucht wurden. Die Ergebnisse ermöglichen daher nur einen kleinen Einblick aber keine abschließende Bewertung der beiden Fragestellungen.

Im Detail werden folgende Hypothesen innerhalb der drei Hauptkapitel überprüft:

Standortveränderungen und Verjüngungsdynamik - Kapitel 2

Die Standortbedingungen werden durch den Borkenkäferbefall erheblich verändert, verhindern jedoch nicht den natürlichen Verjüngungsprozess

Der Jungwuchs wird überwiegend aus Vorausverjüngung bestehen. Nach dem Störungsereignis keimender Jungwuchs ist auf spezielle Mikrohabitate beschränkt.

Das durch den Borkenkäferbefall ausgelöste Absterben der Fichtenaltbestände verändert die Baumartenzusammensetzung und die Bestandesstrukturen von strukturell homogenen reinen Fichtenbeständen in Richtung naturnäherer, stärker strukturierter Mischbestände.

Entwicklung der Alpha-Diversität der untersuchten Artengruppen - Kapitel 3

Durch den Borkenkäferbefall und das Absterben der Fichtenaltbestände ausgelöste Veränderungen von struktureller Heterogenität und Artenvielfalt verschiedener funktioneller Gruppen von Pflanzen, Tieren und Pilzen führen im beginnenden frühsukzessionalen Stadium zu größter Diversität, gehen aber in den darauffolgenden zwei Jahrzehnten durch Kronenschluss des Jungwuchses wieder zurück (closed-canopy pathway). Die AlternativHypothese geht davon aus, dass bei längerfristig unterbleibendem Kronenschluss des Jungwuchses strukturelle Heterogenität und Artenvielfalt über mehrere Jahrzehnte erhöht bleiben (open-canopy pathway).

\section{Entwicklung der Beta-Diversität von Struktur und Artenzusammensetzung - Kapitel 4}

Das durch den Borkenkäferbefall ausgelöste Absterben der Fichtenaltbestände wird im beginnenden frühsukzessionalen Stadium auf lokaler und regionaler Ebene zu einer Heterogenisierung der Bestandesstrukturen und zu erhöhter Beta-Diversität der Artengemeinschaften und deren phylogenetischer und funktioneller Ausstattung führen. Diese erhöhte Beta-Diversität der Strukturen und Artengemeinschaften wird sich auch im Verlauf der Sukzession bis zum fortgeschrittenen frühsukzessionalen Stadium halten und damit die von 
Donato et al. (2012) formulierte These der heterogenen Sukzessionsdynamik nach natürlichen Störungen (homologous precocity pathway) unterstützen und die Bedeutung dieser Stadien für den Erhalt der Biodiversität verdeutlichen. Zusätzlich wird eine erhöhte Gamma-Diversität bei Betrachtung aller drei Sukzessionsstadien erwartet, die in den unbewirtschafteten Wäldern des Nationalparks nicht nur eine zeitliche Dynamik, sondern auch ein räumliches Mosaik auf Landschaftsebene darstellen. 


\section{Ökologische Grundlagen}

Die Literatur über den Einfluss natürlicher Störungen auf Wälder der gemäßigten Zone und über methodische Ansätze zur Erfassung von Biodiversität ist zahlreich und vielfältig und in Lehrbüchern und Reviews bereits mehrfach zusammengestellt und aufbereitet (z.B. Whittaker 1972, Sousa 1984, Attiwill 1994, Bengtsson et al. 2000, Whittaker et al. 2001, Gotelli und Colwell 2001, Schelhaas et al. 2003, Magurran 2004, Leyer und Wesche 2007, Turner 2010). Diese kurze Einführung soll lediglich dem ökologischen Grundverständnis für die nachfolgenden Methoden und Ergebnisse dieser Studie dienen.

\section{Störungsdynamik in Wäldern der gemäßigten Zonen}

Waldökosysteme sind dynamische Systeme, deren Artengemeinschaften und Strukturen einem steten Wandel unterworfen sind (Sousa 1984). Die Dynamik ergibt sich durch eine Vielzahl an Prozessen in verschiedensten zeitlichen und räumlichen Maßstäben und reicht von kleinsträumigen Konkurrenzverhältnissen bis hin zu klimatischen Veränderungen im Laufe vergangener Jahrtausende (Kraus et al. 2013). Störungen, wie Feuer, Stürme, Fluten, Insekten- oder Pilzbefall, gelten mit als wesentlichste Faktoren für die Dynamik von Waldökosystemen (Turner et al. 2003). Störungen unabhängig davon, ob diese anthropogen verursacht oder natürlich sind - werden dabei als „einzelne, zeitlich abgrenzbare Ereignisse, die in ein Ökosystem, die Biozönose oder die Populationsstruktur eingreifen und die Ressourcen, die Substratverfügbarkeit oder das abiotische Umfeld verändern" definiert (White und Pickett 1985). Störung ist damit in ihrem ökologischen Verständnis, im Gegensatz zu Schädigung oder Kalamität, ein wertneutraler Begriff und wird in dieser Studie in diesem ökologischen Sinne verwendet.

Es gibt verschiedene Ansätze, um Störungen in Wäldern zu klassifizieren (Sousa 1984). Roberts (2004) beschreibt drei Klassen natürlicher Störungen, wobei die Erste, zu der Insektenbefall und Stürme zu rechnen sind, vorwiegend den Kronenraum beeinflusst, die Zweite (u.a. Bodenfeuer und Pflanzenfresser) primär Einfluss auf die untere Bestandesschicht (understory) bzw. Bodenvegetation nimmt und die Dritte durch starke Veränderung des gesamten Waldbodens, z.B. durch Hangrutsch, Erosion oder heiße (Kronen-)Feuer, Einfluss auf alle drei Komponenten eines Bestandes ausübt (Abb. 1.1). Darüber hinaus kann es durch Kombination oder zeitliche Abfolge mehrerer Störungen zu kumulativen Effekten kommen (Frelich 2002, Turner et al. 2003). Insektenbefall, wie der Befall durch den Großen Buchdrucker, führt durch das Absterben des Hauptbestandes primär zu Veränderungen im Kronenraum (Abb. 1.1). Durch die Störung selbst kommt es kaum zu einer direkten Störung der Bodenvegetation oder des Waldbodens, auch wenn der indirekte Effekt auf die Bodenvegetation, z.B. durch verstärkte Strahlung am Waldboden, erheblich sein kann (Swanson et al. 2014). 


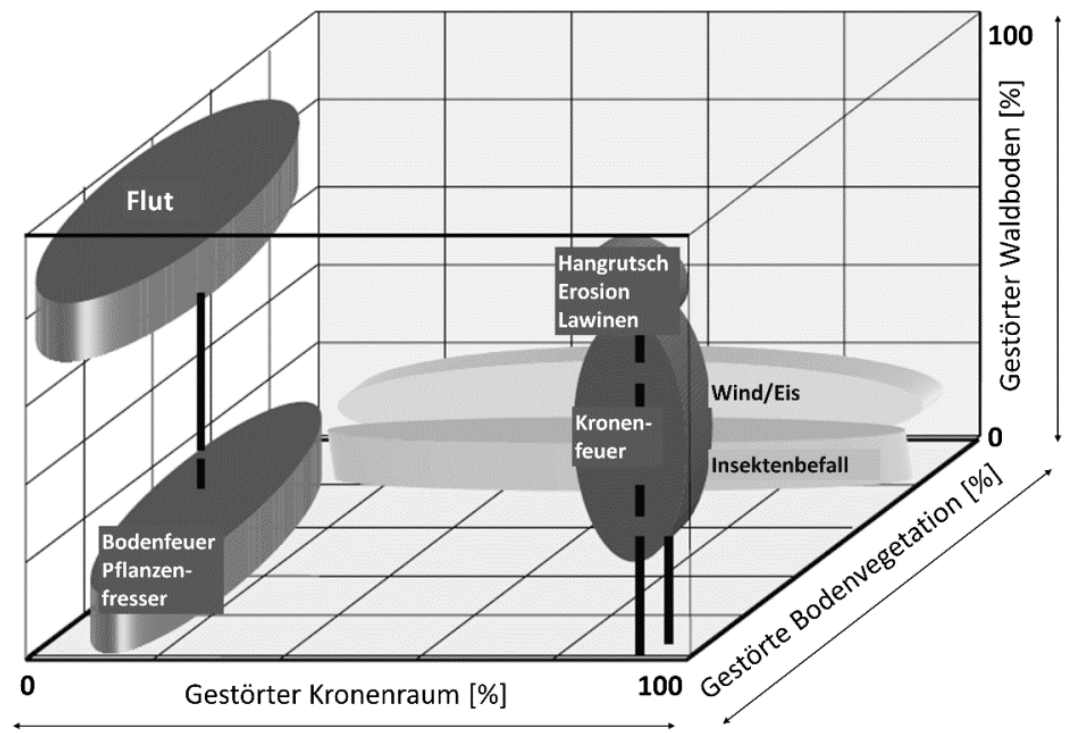

Abb. 1.1 Modelkonzept des Störungseinflusses auf die drei vertikalen Ebenen von Waldökosystemen: Kronenraum, Bodenvegetation und Waldboden. Die Polygone kennzeichnen den direkten Einflussbereich der häufigsten Störungsarten auf die drei Ebenen (nach Roberts 2004).

Fig. 1.1 Conceptual model describing disturbance severity and its impact on the three major vertical layers of forest ecosystem (forest canopy, understory vegetation, forest floor and soil). Polygons represent the ranges in conditions created by the common types of natural disturbances (following Roberts 2004).

Um den Einfluss von Störungen auf Waldökosysteme zu analysieren ist es darum sinnvoll zwischen unmittelbaren, direkten und nachfolgenden Effekten zu differenzieren (Halpern und Spies 1995). Unmittelbare Veränderungen beinhalten beispielsweise die direkte Schädigung existierender Arten, den temporären Verlust der Pflanzendecke, Veränderungen der Mikrotopographie durch Wurzelteller, Veränderungen des Mikroklimas, und das Entstehen von Totholzsubstraten (Abb. 1.2). Nachfolgende Effekte sind meist Teil der Sukzessionsdynamik und wirken indirekt durch Veränderung der Bestandesstruktur (Baumartenzusammensetzung, Bestandesdichte und räumliche Verteilung der Bestandesglieder) und Auswirkungen der Bestandesstruktur auf Parameter wie Bodenstreu, Zersetzungsgrad der Totholzobjekte und Verfügbarkeit von Samen bzw. Sporen. Bei stark gestörten Beständen bestimmt die Flächenausdehnung, ob die Wiederbesiedlung der Störungsfläche durch Ausbreitung der die Störung überdauerter Bestandesglieder (legacies) stattfindet, oder ob die Einwanderung aus ungestörten Nachbarflächen dominiert (Turner 2010). Störungsart, -intensität, -ausdehnung und -häufigkeit beeinflussen damit, neben anderen wesentlichen Parametern, wie dem Artenpool einer Region (Ewald 2002), die Artenzusammensetzung eines Waldökosystems (Abb. 1.2, Roberts 2004). Während sich sehr seltene und sehr häufige Störereignisse dabei kaum diversitätssteigend auswirken, führen mäßig starke Störungen in regelmäßiger Wiederkehr meist zu einer Steigerung der Arten- und Strukturvielfalt (Scherzinger 1996). 


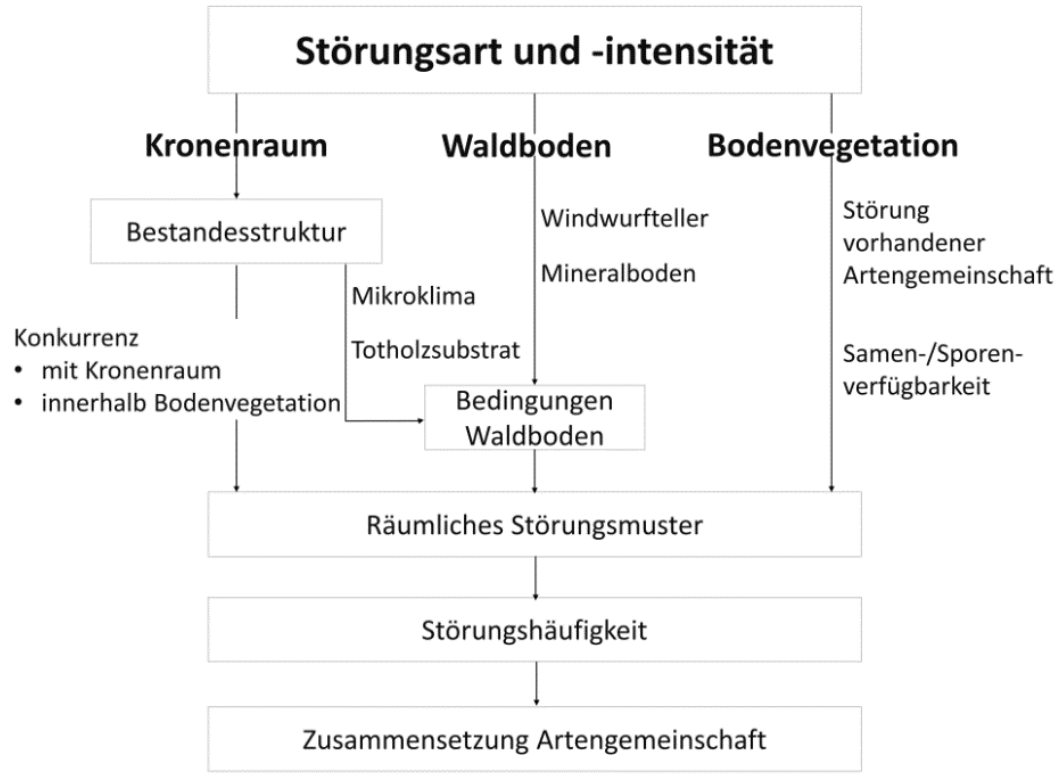

Abb. 1.2 Einflussparameter natürlicher Störungen auf die Artenzusammensetzung von Wäldern (nach Roberts 2004).

Fig. 1.2 Parameters of natural disturbances affecting species composition of forests (following Roberts 2004).

\section{Erfassung von Biodiversität}

Nach der Biodiversitäts-Konvention von 1992 (Convention on Biological Diversity, CBD) bezeichnet Biologische Diversität „die Variabilität unter lebenden Organismen jeglicher Herkunft, darunter unter anderem Land-, Meeres- und sonstige aquatische Ökosysteme und die ökologischen Komplexe, zu denen sie gehören. Sie umfasst die Vielfalt innerhalb von Arten [genetische Vielfalt], zwischen den Arten, sowie die Vielfalt der Ökosysteme“ (United Nations 1992). Die Bezeichnung Biodiversität ist eine auf Rosen (1985) zurückgehende Wortkreation mit identischer Bedeutung zu biologischer Diversität bzw. Vielfalt (Magurran 2004).

Es ist so gut wie ausgeschlossen, die Artenvielfalt eines Gebietes fehlerfrei zu ermitteln, da die beobachteten Arten fast immer nur einen Teilausschnitt der gesamten Artengemeinschaft eines Gebietes darstellen (Gotelli und Colwell 2001). Allein für den Aspekt der Vielfalt zwischen Arten, nachfolgend Artenvielfalt genannt, besteht darum eine schier unüberschaubare Vielzahl verschiedener Messgrößen, Indizes und Modelle im Bestreben sich der Ermittlung der tatsächlichen Artenvielfalt anzunähern (Ricotta 2005). Eine Anzahl beobachteter Arten einer Artengemeinschaft kann je nach Größe, zu der sie in Bezug gesetzt wird - der Beobachtungsfläche, dem Beobachtungszeitraum, der Anzahl an Individuen - zu unterschiedlichen Ergebnissen führen (Gotelli und Colwell 2001). Werden Artenzahlen in Bezug zu einer Anzahl an Individuen angegeben, spricht man von Artenreichtum (species richness), betrachtet man Artenzahlen in Bezug zu einer Flächengröße oder -einheit, spricht man von Artendichten (species density, Magurran 2004). Da in 
dieser Studie identische Bezugseinheiten für den Vergleich zwischen verschiedenen Sukzessionsstadien zu Grunde liegen $-500 \mathrm{~m}^{2}$ große Probeflächen für Gefäßpflanzen und totholzbesiedelnde Pilze bzw. baugleiche Fallensysteme für Arthropoden und Mollusken - wird in dieser Studie hauptsächlich die Messgröße der Artendichten verwendet. Als reine Artenzahl ist diese, im Gegensatz zum mathematischen berechneten Artenreichtum, intuitiv verständlich.

Zusätzlich kann durch die Evenness der Grad der Gleichverteilung von Individuen auf die Arten in einer Lebensgemeinschaft angegeben werden (Gotelli und Colwell 2001). Zahlreiche Indizes und Modelle kombinieren Artendichte/Artenreichtum und Evenness durch mathematische Formeln; die bekanntesten Beispiele sind Shannon und Simpson-Index (Magurran 2004). Die Erkenntnis, dass nicht allein das Wissen um taxonomische Artenzahlen relevant für das Verständnis von Funktionalität oder Anpassungsfähigkeit eines Ökosystems sein kann, erweiterte den Ansatz der Artenvielfalt in den letzten Jahrzehnten verstärkt um Methoden zur Ermittlung phylogenetischer und funktioneller Diversität (Magurran 2004). Phylogenetische Vielfalt misst dabei die Variation innerhalb der Taxonomie (des Stammbaums) der Artengemeinschaften, während funktionelle Diversität meist als Heterogenität innerhalb eines aus Merkmalswerten der Arten (z.B. Größe, Ausbreitungsmechanismus, Ernährungstyp) konstruierten Dendrogramms berechnet wird, und ein aussagekräftiges Instrument zur Verdeutlichung der Konsequenzen von Artaussterbeprozessen auf Ebene der Ökosystemfunktionen darstellt (Magurran 2004).

Whittaker (1972) entwickelte erstmals ein differenziertes System zur Klassifizierung der Biodiversität in unterschiedliche Maßstabsebenen und führte die Bezeichnungen Punkt- und Pattern-, Alpha-, Beta-, Gamma-, Delta- und Epsilon-Diversität ein (Tabelle 1.1). Dabei dient die Alpha-Diversität als Begriff für die Artenvielfalt innerhalb eines Habitats. Die Gamma-Diversität ergibt sich aus der Summe der Alpha-Diversität innerhalb einer größeren Raumeinheit und kennzeichnet die gesamte Vielfalt einer Landschaft. Im Gegensatz zum Zustandsmaß der Alpha- oder Gamma-Diversität ergibt sich die Beta-Diversität als ein Vergleichsmaß zwischen Habitaten. Mehrere Habitate können jeweils durch eine hohe Artenvielfalt (Alpha-Diversität) geprägt sein, sich in ihrer Artengemeinschaft untereinander aber kaum unterscheiden und damit eine geringe Beta-Diversität aufweisen. BetaDiversität ist dimensionslos und wird über (Un-)Ähnlichkeitswerte ausgedrückt (Magurran 2004). Sie gibt Aufschluss über den Artenwechsel zwischen verschiedenen Habitaten (Whittaker 1972) und ermöglicht damit z.B. die Untersuchung der Heterogenität von Artengemeinschaften in verschiedenen Sukzessionsstadien auf Landschaftsebene. Alpha-, Beta- und Gamma-Diversität sind die gebräuchlichsten Werte innerhalb der Klassifizierung von Whittaker und werden auch in dieser Studie wiederholt verwendet. Die genaue Berechnung der einzelnen Biodiversitätsmaße wird in der jeweiligen Methodik der Ergebniskapitel erläutert. 
Tabelle 1.1 Kategorien der Diversität in Abhängigkeit des Erhebungsmaßstabs (Magurran 2004 nach Whittaker 1972).

Table 1.1 Categories of diversity as a function of surveying scale (Magurran 2004 following Whittaker 1972).

\begin{tabular}{lll}
\hline Maßstab & Aufnahme-Diversität & Differenzierungs-Diversität \\
\hline $\begin{array}{l}\text { Innerhalb Stichprobe } \\
\text { Zwischen Stichproben, innerhalb Habitat } \\
\text { Innerhalb Habitat }\end{array}$ & Punkt-Diversität & Pattern-Diversität \\
$\begin{array}{l}\text { Zwischen Habitaten, innerhalb Landschaft } \\
\text { Innerhalb Landschaft }\end{array}$ & Alpha-Diversität & Beta-Diversität \\
$\begin{array}{l}\text { Zwischen Landschaften } \\
\text { Innerhalb biogeographischer Region }\end{array}$ & Gamma-Diversität & Delta-Diversität \\
\hline
\end{tabular}




\section{Untersuchungsgebiet Nationalpark Berchtesgaden}

Der Naturraum und die forstgeschichtlichen Hintergründe des Nationalparks Berchtesgaden wurden bereits ausführlich in der Literatur beschrieben (z.B. Knott et al. 1988, Spandau 1988, Kral und Rall 1990, Konnert und Siegrist 2000). Die folgende Einführung in das Untersuchungsgebiet beschränkt sich daher auf Informationen, die für das Verständnis dieser Studie unmittelbar relevant sind. Bei tiefergehendem Interesse am Gebiet sei an den Nationalparkplan und die darin genannte Literatur verwiesen (Nationalpark Berchtesgaden 2001).

Der Nationalpark Berchtesgaden wurde 1978 gegründet und erweiterte damit den 1910 ausgewiesenen Pflanzenschonbezirk Berchtesgadener Alpen und das 1921 verankerte Naturschutzgebiet Königssee (Nationalpark Berchtesgaden 2001). Das Nationalparkgebiet umfasst 20.808 ha von der submontanen bis zur alpinen Stufe und liegt, ca. 30 km südlich von Salzburg, im südöstlichsten Teil Deutschlands (Abb. 1.3).

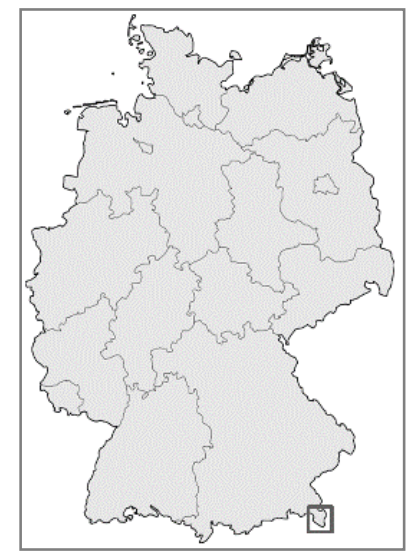

Abb. 1.3 Lage des Nationalparks Berchtesgaden im südöstlichsten Teil Deutschlands.

Fig. 1.3 Location of the Berchtesgaden National Park in south-eastern Germany.

Klimatisch liegt der Nationalpark Berchtesgaden im Übergangsbereich von atlantischer zu kontinentaler Prägung (Nationalparkverwaltung Berchtesgaden 2003). Die Jahresmitteltemperatur variiert je nach Höhenlage zwischen $+7{ }^{\circ} \mathrm{C}$ und $-2{ }^{\circ} \mathrm{C}$, der mittlere Jahresniederschlag liegt zwischen 1.500 und $2.600 \mathrm{~mm}$ (Referenzperiode 2001-2010, Kraller et al. 2012). Die durchschnittliche Schneedeckendauer steigt von etwa 110 Tagen in den Tälern, auf 200 Tage auf $1.500 \mathrm{~m}$ ü. NN und auf 270 Tage auf $2.000 \mathrm{~m}$ ü. NN an (Nationalpark Berchtesgaden 2001).

Geologisch wird das Gebiet im Wesentlichen durch Sedimentgesteine der Trias bestimmt. Landschaftsprägend sind Dachsteinkalk und Ramsaudolomit, wobei der überwiegend aus Calciumkarbonat $\left(\mathrm{CaCO}_{3}\right)$ bestehende Dachsteinkalk durch Lösungsverwitterung wenig zur Bodenbildung beiträgt und der vorwiegend aus Calcium-Magnesium-Karbonat $\left(\mathrm{CaMg}\left(\mathrm{CO}_{3}\right)_{2}\right)$ aufgebaute Ramsaudolomit durch physikalische Verwitterung schuttbildend in Erscheinung tritt (Kolb 2013). Vereinzelt treten Mergelschichten an die Oberfläche, die durch ihren höheren Tonanteil leichter verwittern und sich meist zu tiefgründigeren und fruchtbareren Böden entwickeln. Sehr 
selten finden sich Standorte mit sauer verwitternden Kieselgesteinen (Kolb 2013). Die häufigsten Bodentypen sind Rendzinen mit mittleren und flachgründigen Horizonten, Tangel-Felshumusböden, mit organischen Humusauflagen von $>15 \mathrm{~cm}-35 \mathrm{~cm}$ besonders in höheren Lagen und an steilen Hängen, und verschiedene Formen der Braunerde in den tieferen Lagen (Kolb 2013).

Etwa 10.000 ha, d.h. 48 \%, der Nationalparkfläche sind von Wald bestockt. (Nationalpark Berchtesgaden 2001). Die potentielle natürliche Vegetation entspricht submontan Buchenwäldern mit Beimischungen von Edellaubhölzern, montan und hochmontan Bergmischwäldern aus Europäischer Buche, Gemeiner Fichte und Weißtanne und subalpin Hochlagenwäldern mit Gemeiner Fichte, Europäischer Lärche (Larix decidua Mill.) und Zirbe (Pinus cembra L.). Etwa ein Viertel der Waldfläche nimmt subalpin und schuttbesiedelnd die Bergkiefer (Pinus mugo Turra) ein (Köstler und Mayer 1974). Jahrhunderte intensivster Holznutzung für die Salinenindustrie haben die natürlichen Wälder jedoch stark überprägt. Durch bessere Flößeigenschaften und gleichmäßigeres Brennverhalten der Gemeinen Fichte bei gleichzeitig geringerer Verbissbelastung durch Wild- und Nutztiere führte der menschliche Einfluss in erreichbaren Lagen überwiegend zu reinen Fichtenbeständen (Knott et al. 1988, Konnert und Siegrist 2000). Durch jahrhundertelange Holznutzung kam es durch Nährstoffentzug und Kahlschlagswirtschaft zu einer deutlichen Reduktion der Humusauflagen in den Waldbeständen und damit, besonders auf den Tangel-Felshumusböden, zu reduzierter Nährstoffverfügbarkeit und Wüchsigkeit (Bochter et al. 1981, Knott et al. 1988, Christophel et al. 2013, Prietzel und Christophel 2014). Zusätzlich reduzierten die hohen Schalenwildbestände, besonders seit Einrichtung des Hofjagdbezirkes 1810, über knapp zwei Jahrhunderte erheblich die natürliche Regenerationsfähigkeit der Waldbestände im Nationalparkgebiet (Knott et al. 1988).

Um den verschiedenen Ansprüchen an den Nationalpark - Schutz der Naturgüter, Erhalt der Kulturlandschaft, Förderung von Forschung, Umweltbildung und Erholung - gemäß der Nationalparkverordnung (Bayerisches Staatsministerium für Landesentwicklung und Umweltfragen 1987) gerecht zu werden, ist die Nationalparkfläche in folgende Managementzonen unterteilt (Abb. 1.4):

Permanente Pflegezone: 23,5 \% Flächenanteil = 4.884 ha, davon 3.400 ha Waldfläche Vorrangiges Ziel in der permanenten Pflegezone ist die Pflege der Kulturlandschaft, insbesondere durch den Erhalt der Almwirtschaft. Auch Bereiche, die stark durch die Erholungsnutzung frequentiert werden, wie Königssee und St. Bartholomä, liegen innerhalb der permanenten Pflegezone. Die Waldflächen der permanenten Pflegezone werden mehrheitlich durch folgende Maßnahmenbereiche abgedeckt: 
Der Maßnahmenbereich Borkenkäferbekämpfung liegt mit 1.911 ha vollständig innerhalb der permanenten Pflegezone am Randbereich des Nationalparks. Nur hier finden Maßnahmen der Borkenkäferbekämpfung zum Schutz angrenzender Wirtschaftswälder durch Entnahme oder Entrindung befallener Bäume statt.

Der Maßnahmenbereich Waldpflege überschneidet sich auf großer Fläche mit dem Maßnahmenbereich Borkenkäferbekämpfung und liegt mit 2.130 ha ebenfalls vollständig in der permanenten Pflegezone. Hier finden Maßnahmen zur Wiederherstellung standortheimischer Waldgesellschaften statt, z.B. durch Einbringen von Jungpflanzen der Europäischen Buche und der Weißtanne in den sekundären Fichtenwäldern der tieferen Lagen nach femelartiger Durchforstung oder Borkenkäferbefall.

Temporäre Pflegezone: 9,9 \% Flächenanteil = 2.064 ha, davon 1.618 ha Waldfläche

In der temporären Pflegezone wurden, zeitlich begrenzt, ausschließlich Maßnahmen zur Wildbestandsregulierung von Rotwild (Cervus elaphus L.), Rehwild (Capreolus capreolus L.) und Gamswild (Rupicapra rupicapra L.) durchgeführt. Seit 2014 hat die Nationalparkverwaltung die Wildbestandsregulierung in der temporären Pflegezone versuchsweise eingestellt. Mittelfristig sollen diese Bereiche zur Kernzone übergehen.

Kernzone: 66,6 \% Flächenanteil = 13.860 ha, davon 5.058 ha Waldfläche

Mit Ausnahme von Erholungsnutzung und vereinzelten Aktivitäten von Bundeswehr und Bundespolizei finden in der Kernzone keine Nutzungen statt.

Im Anschluss an die Winterstürme Vivian und Wiebke im Februar 1990 (mit, nach eigenen CIRAuswertungen, ca. 140 ha Windwurffläche), kam es im Gebiet erstmals seit Gründung des Nationalparks zu großflächigerem Befall durch Borkenkäfer (besonders durch Ips typographus, Nationalpark Berchtesgaden 2001). Nur im Maßnahmenbereich Borkenkäferbekämpfung am Randbereich des Nationalparks wurden zum Schutz des angrenzenden Wirtschaftswald befallene Fichten geräumt oder entrindet. Außerhalb des Maßnahmenbereichs Borkenkäferbekämpfung, auf ca. 8.000 ha Waldfläche unterblieben derartige Eingriffe. Ende der 1990er Jahre ging der jährliche Neubefall durch Borkenkäfer auch außerhalb des Maßnahmenbereichs Borkenkäferbekämpfung natürlicherweise zurück. Erst nach dem Wintersturm Kyrill im Februar 2007 und dem 2008 nachfolgenden Sturm Emma (mit insgesamt ca. 100 ha Windwurffläche) kam es erneut zu großflächigem Borkenkäferbefall. In Fischunkel am Obersee und auf dem Hochplateau der Regenalm, südöstlich des Königssees vergrößerte ein Föhnsturm im November 2010 die Windwurfflächen um weitere etwa 30 ha. Während der Schwerpunkt des Windwurfs, und damit auch des darauffolgenden Borkenkäferbefalls, in den 1990er Jahren in montaner und hochmontaner Höhenstufe zu finden war 
und die Befallsflächen nur sehr vereinzelt Größen von einem Hektar überschritten, lagen die Windwurfflächen von 2007, 2008 und 2010 in allen Höhenlagen. Damit breitete sich der Borkenkäferbefall nach 2007 bis in die subalpine Höhenstufe aus und erreichte in mehreren Fällen Dimensionen von mehreren Hektar Befallsfläche (Winter und Becker 2015).

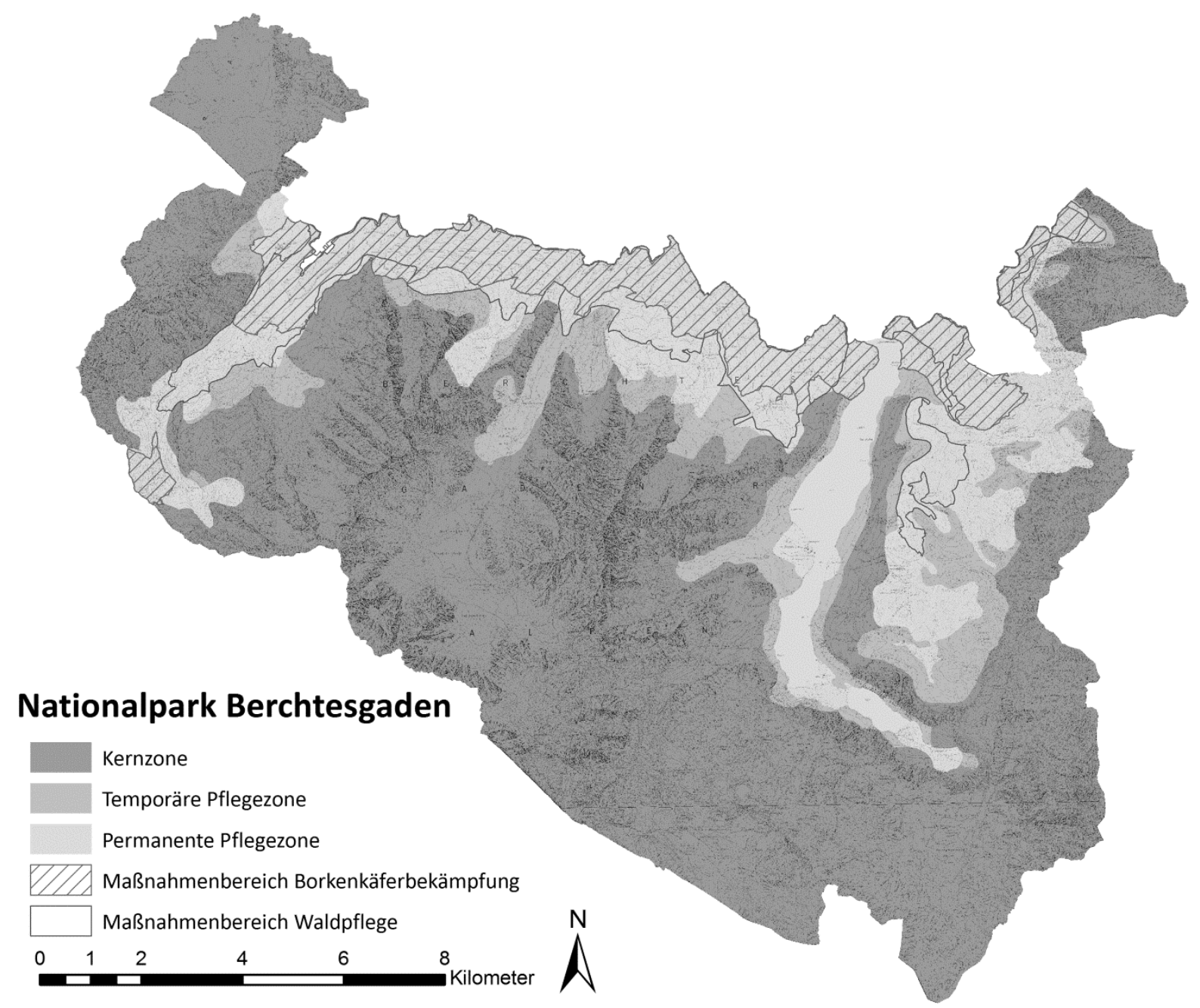

Abb. 1.4 Zonierung des Nationalparks Berchtesgaden (verändert nach Nationalpark Berchtesgaden 2001).

Fig. 1.4 Zonation of the Berchtesgaden National Park (modified following Nationalpark Berchtesgaden 2001). 


\section{Untersuchungsdesign}

\section{Konzept der unechten Zeitreihe}

Das Absterben der sekundären Fichtenwälder durch Borkenkäferbefall wird die künftige Waldentwicklung über mehrere Baumgenerationen hinweg prägen (Kupferschmid 2003). Um langfristige Entwicklungen verstehen zu können, benötigt es langfristige Beobachtungszeiträume (Gadow 2003). Fundierte Aussagen liefern echte Zeitreihen (time series), d.h. stichprobenbasierte Messreihen von Beständen, deren Zustand periodisch immer wieder erhoben wird, um deren Entwicklung zu untersuchen und $\mathrm{zu}$ dokumentieren. Diese Methodik bedingt jedoch die Notwendigkeit von wenigstens zwei Aufnahmen zu verschiedenen Zeitpunkten, um eine Aussage über die Entwicklung treffen zu können. Da aus dem Zeitraum des ersten großflächigeren Borkenkäferbefalls im Nationalpark in den 1990er Jahren keine Informationen zu den damaligen Bestandesbedingungen vorlagen, basiert diese Studie auf dem Konzept einer unechten Zeitreihe (chronosequence). Bei dem Konzept einer unechten Zeitreihe werden zu einem Zeitpunkt verschiedene Entwicklungsstadien aufgenommen, die sich aus einem vergleichbaren Ausgangzustand heraus entwickelt haben und im Laufe der Entwicklung vergleichbaren Einflussgrößen unterlagen (Gadow 2003). Dies bedeutet in dieser Studie, dass auf vergleichbaren Standorten stichprobenbasiert Bestände ausgewählt wurden, die sich zum Zeitpunkt der Aufnahmen 2012 und 2013 in unterschiedlichen Entwicklungsstadien vor bzw. nach Borkenkäferbefall befanden. Die Charakterisierung der Standorte beinhaltete digital vorliegende Informationen zu Höhenlage, Exposition, Bodentyp und potentiell natürlicher Vegetation (Nationalpark Berchtesgaden 2001).

Die ausgewählten Entwicklungsstadien waren:

Fichtenaltbestände (mature spruce stands): Lebende, weitgehend reine, sekundäre Fichtenaltbestände, die potentiell von Borkenkäfern befallbar sind. D.h., Fichtenbestände, die auf einer Fläche von 0,05 ha mindestens fünf Fichten mit einem Alter $>80$ Jahre aufwiesen.

Beginnendes frühsukzessionales Stadium (initial early-seral stage): Durch Borkenkäferbefall im Nachgang an Kyrill (2007) abgestorbene Fichtenaltbestände, die sich zum Zeitpunkt der Aufnahmen 1 bis 5 Jahre nach Absterben des Bestandes am Beginn der Sukzession befanden. Dieses Stadium wird im Folgenden zur vereinfachten Lesbarkeit beginnende Sukzession genannt.

Fortgeschrittenes frühsukzessionales Stadium (advanced early-seral stage): Durch Borkenkäferbefall im Nachgang an Vivian/Wiebke (1990) abgestorbene Fichtenaltbestände, 
die sich zum Zeitpunkt der Aufnahmen 17-25 Jahre nach Absterben des Bestandes bereits in einem fortgeschrittenen Sukzessionsstadium befanden. Dieses Stadium wird im Folgenden zur vereinfachten Lesbarkeit fortschreitende Sukzession genannt.

In Anbetracht der langen Zeit, die der Borkenkäferbefall die Bestände in ihrer weiteren Entwicklung voraussichtlich prägen wird, sind die untersuchten knapp 30 Jahre ein kurzes Zeitfenster. Bestände mit länger als 25 Jahre zurückliegendem Borkenkäferbefall waren vereinzelt im Gebiet zu finden, aber nicht in ausreichender Menge, um daraus verlässliche Ergebnisse ableiten zu können. Vom Ausgangszustand der unbefallenen Fichtenaltbestände, bis zum vereinzelt bereits stattfindenden Kronenschluss im Jungwuchs deckt diese Studie dennoch einen wesentlichen Zeitraum für das Verständnis künftiger Entwicklung und relevanter Einflussgrößen nach dem Störungsereignis ab. Die im Rahmen dieser Studie erhobenen Probeflächen sind darüber hinaus als Dauerprobeflächen angelegt und werden durch künftige Aufnahmen und dem dadurch entstehenden Gewinn echter Zeitreihen neue und erweiterte Auswertungsmöglichkeiten bieten.

Für die Forschungsfragen I bis III wurden außerhalb des Maßnahmenbereichs Borkenkäfer in montaner (ca. 700-1.200 m ü. NN), hochmontaner (ca. 1.200-1.400 m ü. NN) und subalpiner Lage (ca. 1.400-1.800 $\mathrm{m}$ ü. $\mathrm{NN})$, sonnseitig $\left(112,5^{\circ}-292,5^{\circ}\right)$ und schattseitig $\left(292,5^{\circ}-112,5^{\circ}\right)$, je sechs Probeflächen je Variante angelegt. Der Borkenkäferbefall in den 1990er Jahre fand schwerpunktmäßig in tieferen Höhenstufen statt und führte überwiegend zu Befallsflächen mit weniger als einem Hektar Flächenausdehnung. Aus diesem Grund konnten keine Flächen der fortschreitenden Sukzession in der subalpinen Lage erfasst werden. Zudem wurden zur Vergleichbarkeit der Ergebnisse sämtliche Probeflächen der beginnenden und fortschreitenden Sukzession in Befallsflächen mit maximal einem Hektar Flächenausdehnung angelegt. Insgesamt wurden zur Bearbeitung von Fragestellung I bis III 96 Probeflächen erfasst (Abb. 1.5, weißer Hintergrund).

Im Nachgang an Kyrill erreichte der Borkenkäferbefall in einigen Fällen Dimensionen von mehreren Hektar Befallsfläche im Nationalpark. Da sich bei zunehmender Größe der Störungsflächen deutliche Veränderungen der bestandesklimatischen Bedingungen, des Samenangebots, des Humusabbaus und des physikalischen Gefährdungspotentials des Jungwuchses (z.B. durch steigendes Risiko durch Schneegleiten, Lawinen und Steinschlag) erwarten lassen (Dorren et al. 2004, Roberts 2004), wurden außerhalb des Maßnahmenbereichs Borkenkäferbekämpfung zusätzlich in drei Gebieten des Nationalparks jeweils zwei Borkenkäfer-Befallsflächen $>1$ ha Flächenausdehnung der beginnenden Sukzession in schattseitiger montan/hochmontaner und subalpiner Lage ausgewählt. Innerhalb dieser Borkenkäfer-Befallsflächen wurde anhand eines Stichprobenrasters und stratifizierter Zufallsauswahl jeweils eine Probefläche am Nord-, Ost-, Süd- und Westrand der Befallsfläche und je 
nach Flächenausdehnung mehrere Probeflächen im Mittelbereich der Befallsfläche angelegt. Das Stichprobenraster entsprach mit 25,24 x 25,24 m dem Durchmesser der Probekreise. Eine Probefläche repräsentierte dabei 0,4 ha Befallsfläche. Insgesamt wurden damit auf 6 Befallsflächen 38 Probeflächen angelegt (Abb. 1.5, dunkelgrauer Hintergrund). Diese Teiluntersuchung wurde schwerpunktmäßig im Rahmen von zwei Bachelorarbeiten der Hochschule Weihenstephan-Triesdorf von Karin Beer und Tobias Wiepcke durchgeführt (Beer und Wiepcke 2014). Zur Auswertung wurden neben den 38 Probeflächen in den großen Befallsflächen, die vergleichbaren Probeflächen in den kleinen Befallsflächen herangezogen, d.h. jene in der beginnenden Sukzession in montaner, hochmontaner und subalpiner, schattseitiger Lage.

Innerhalb des Maßnahmenbereichs Borkenkäferbekämpfung erfolgt zum Schutz angrenzender Wirtschaftswälder die vollständige Räumung oder Entrindung des von Borkenkäfern befallenen Fichtenholzes mit anschließender unterstützender Pflanzung von Europäischer Buche und Weißtanne (Nationalpark Berchtesgaden 2001). Als Nebenaspekt dieser Studie wurde der Einfluss des Managements auf die Jungwuchsdichten, auf Baumartenzusammensetzung und Artenvielfalt durch Vergleich von Flächen außerhalb und innerhalb des Maßnahmenbereichs Borkenkäferbekämpfung untersucht. Aufgrund des räumlichen Schwerpunktes des Maßnahmenbereichs bezieht sich diese Untersuchung nur auf schattseitige montane Lagen der beginnenden Sukzession. Zur Untersuchung von Fragestellung $\mathrm{V}$ (Einfluss der Flächenräumung) wurden daher zusätzlich innerhalb des Maßnahmenbereichs Borkenkäferbekämpfung in montaner schattseitiger Lage sechs Probeflächen der beginnenden Sukzession eingerichtet (Abb. 1.5, hellgrauer Hintergrund). 


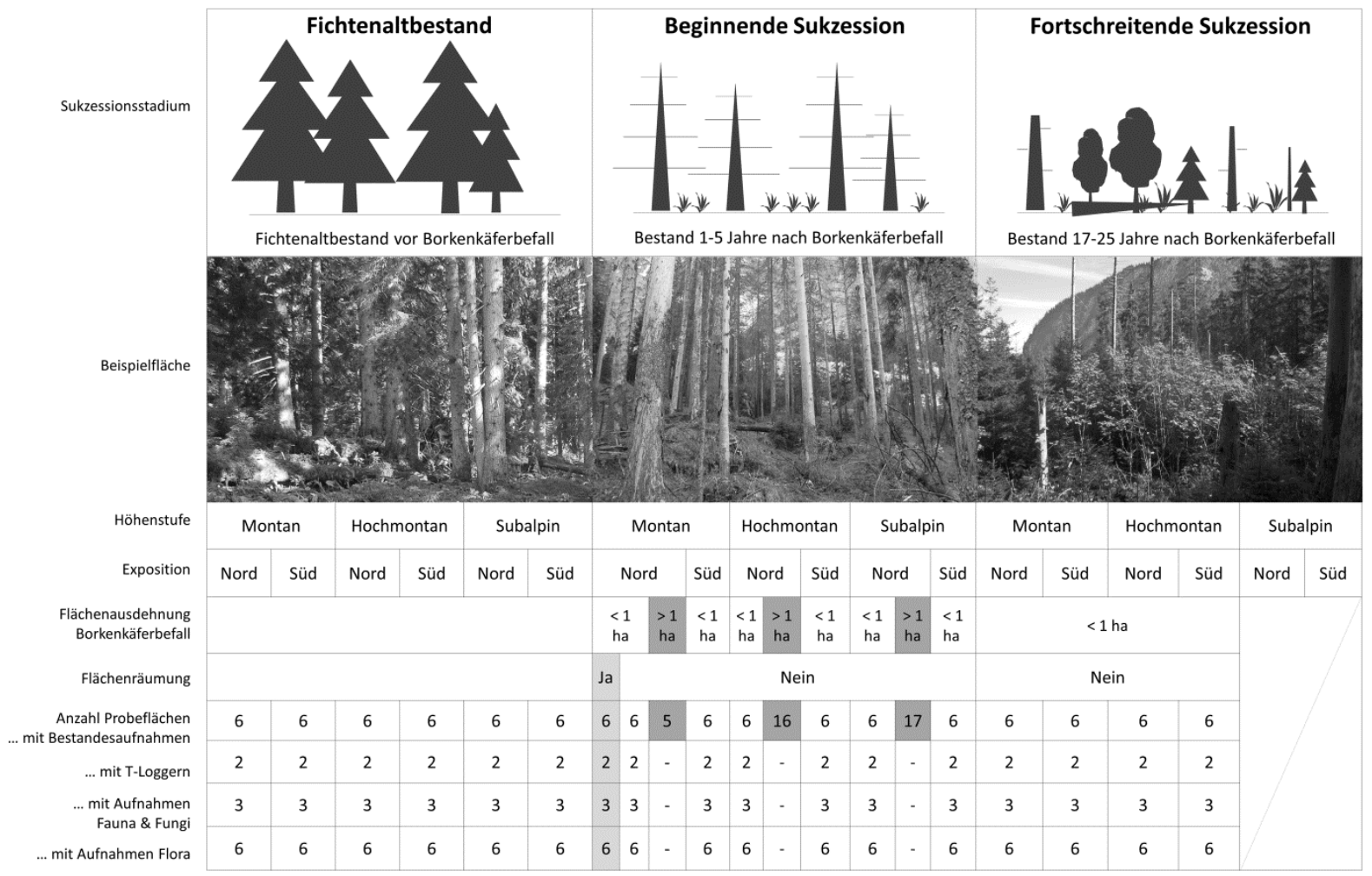

Abb. 1.5 Konzept der unechten Zeitreihe und des Untersuchungsdesigns. Die grau hinterlegten Flächen kennzeichnen die zusätzlich für Fragestellung IV (Einfluss der Flächenausdehnung des Borkenkäferbefalls, dunkelgrau) und V (Einfluss der Flächenräumung, hellgrau) angelegten Probeflächen.

Fig. 1.5 Concept of chronosequence and study design. Colored cells mark study plots installed for research question IV (Effect of gap size, dark grey) and V (Effect of salvage logging, light grey).

Die Auswahl der einzelnen Probeflächen erfolgte anhand von CIR-Luftbildern des Nationalparkgebiets der Jahre 1990, 1997, 2009 und 2012, auf denen die durch Borkenkäferbefall abgestorbenen stehenden Bestände der beiden Befallszeiträume geographisch lokalisiert werden konnten. Die Auswahl wurde im Gelände verifiziert. Für die Stadien der beginnenden und fortschreitenden Sukzession, mit 90-100 \% Mortalität des Hauptbestandes, wurden die Probeflächen jeweils in der geographischen Mitte der Störungsflächen eingerichtet. Probeflächen der Fichtenaltbestände wurden vorrangig auf dem Stichprobenraster $\left(\begin{array}{llllll}100 & \text { x } & 200 & \mathrm{~m}\end{array}\right)$ der nationalparkinternen Waldinventur (Konnert und Siegrist 2000) angelegt. Wo in Einzelfällen keine der Definition entsprechenden Fichtenaltbestände auf dem Stichprobenraster in der Nähe der Störungsflächen zu finden waren, wurden die Probeflächen unabhängig vom Stichprobenraster der Waldinventur in entsprechende nahgelegene und standörtlich vergleichbare Fichtenaltbestände gelegt. Die Probeflächen verteilten sich über die gesamte fichtendominierte Fläche des Nationalparks (Abb. 1.6). 


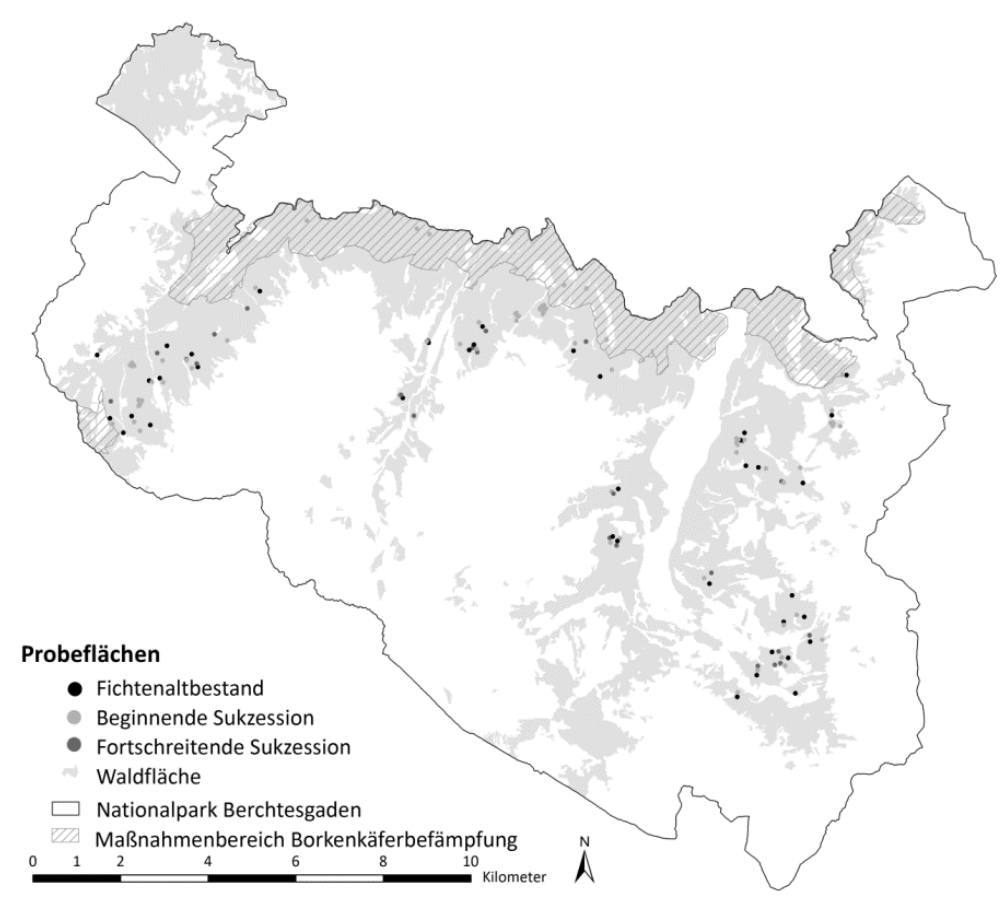

Abb. 1.6 Lage der Probeflächen im Nationalpark.

Fig. 1.6 Location of the study plots in the national park.

\section{Probeflächendesign}

Für die Aufnahmen wurden, in Anlehnung an die Methodik der nationalparkinternen Waldinventur (Konnert und Siegrist 2000), $500 \mathrm{~m}^{2}$-große kreisförmige Probeflächen im Gelände eingemessen. Durch die im Gelände durchgeführte Hangkorrektur entspricht die Flächengröße $500 \mathrm{~m}^{2}$ bei horizontaler Betrachtung. Abhängig von den Aufnahmeparametern variierte die Größe der tatsächlichen Aufnahmefläche innerhalb der Probefläche (Abb. 1.7). Die geographischen Koordinaten der Probeflächenmittelpunkte wurden mit Trimble-GPS-Gerät erfasst und im Nachgang mit den Daten der auf dem Dach der Nationalparkverwaltung in Berchtesgaden installierten Referenzstation korrigiert. Die Probeflächenmittelpunkte wurde mit Bodenmagnet in ca. $10 \mathrm{~cm}$ Bodentiefe dauerhaft festgelegt und zusätzlich für die Dauer der Aufnahmen, ebenso wie die Mittelpunkte der $1 \mathrm{~m}^{2}$ Kleinflächen und die Außengrenze des Probekreises mit Bambusstangen markiert (Abb. 1.7). 


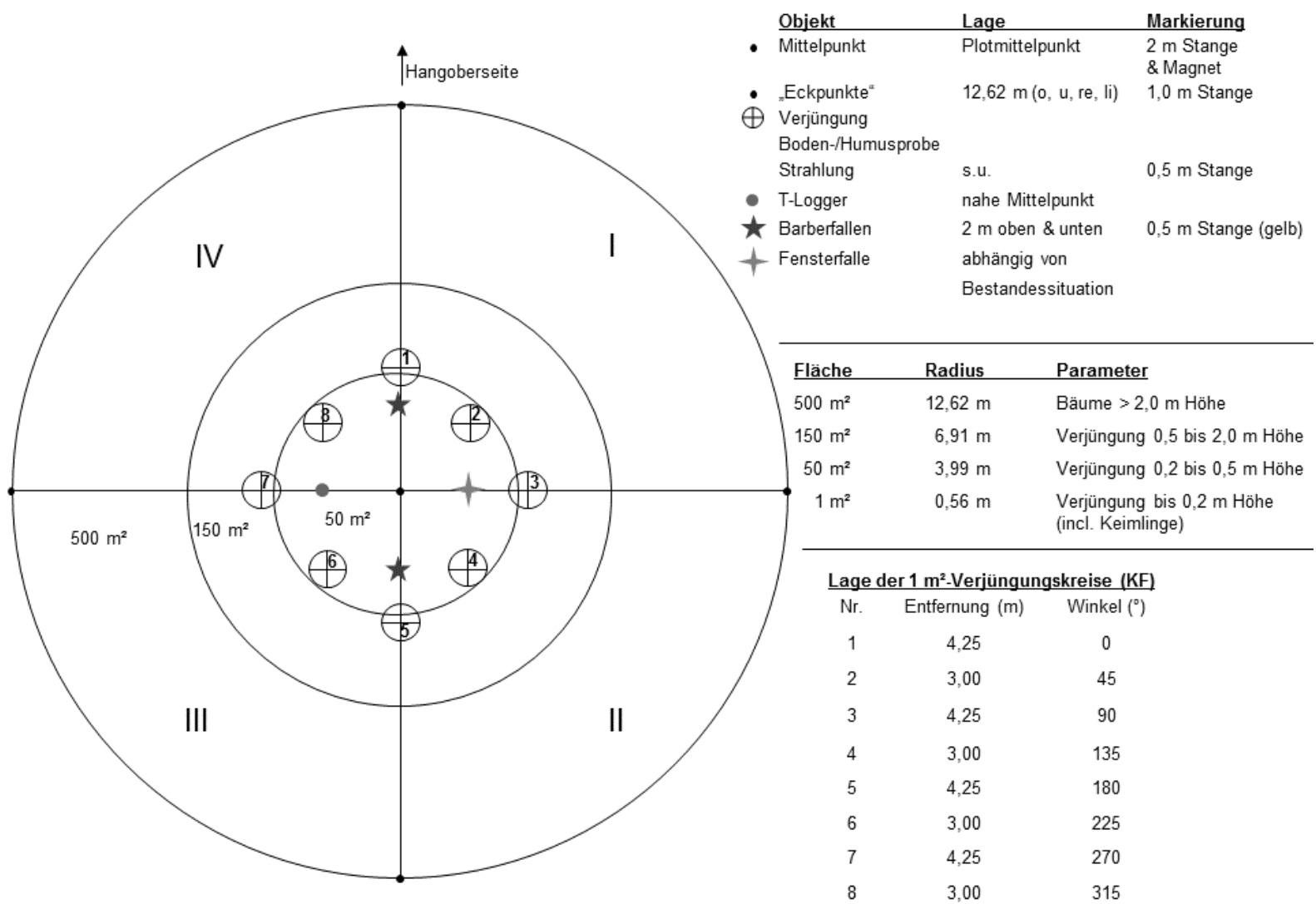

Abb. 1.7 Kombiniertes Probeflächendesign mit den für die verschiedenen Aufnahmeattribute variierenden Aufnahmeflächen.

Fig. 1.7 Design of study plots combining varying plot sizes depending on survey attributes. 


\section{Aufnahmeverfahren}

\section{Befallsflächen}

Zur Erfassung der räumlichen Ausdehnung des Borkenkäferbefalls nach 1990 und 2007 wurden sämtliche Befallsflächen außerhalb des Maßnahmenbereichs Borkenkäferbekämpfung in einer GISAnalyse in ArcGIS 10.0 anhand der CIR-Luftbilder von 1997 und 2012 manuell digitalisiert. Methodik und Ergebnisse dieser Analyse sind im Artikel in Kapitel 2 publiziert.

\section{Standort}

Die geographische Höhe der Probeflächenmittelpunkte wurde im digitalen Geländemodell (DEM, $<1 \mathrm{~m}$ Auflösung) in ArcGIS 10.0 ermittelt. Die topographischen Parameter Exposition und Hangneigung wurden mit Suunto Kompass und Neigungsmesser im Gelände erhoben.

\section{Temperatur}

Zur Quantifizierung der Temperaturunterschiede auf den Probeflächen in Abhängigkeit vom Entwicklungsstadium wurden auf jeweils zwei der sechs Wiederholungen je Variante ein Datenlogger mit zwei externen Temperatursensoren installiert (HOBO Pro v2; siehe Abb. 1.5). Dabei wurde jeweils ein Sensor zur Messung der Bodentemperatur in $5 \mathrm{~cm}$ Bodentiefe eingebaut. Der zweite Sensor zur Erfassung der Lufttemperatur wurde im Strahlungsschutz (HOBO Sonnenschutzvorrichtung) in einem Meter Höhe über Grund installiert. Beide Sensoren speicherten die halbstündlichen erfassten Messwerte im integrierten Datenlogger, der halbjährlich ausgelesen wurde.

\section{Boden}

Zur Erfassung von Humusform und -mächtigkeit wurde neben jeder $1 \mathrm{~m}^{2}$-Kleinfläche, mit möglichst vergleichbaren Bedingungen zur Situation innerhalb der Kleinfläche, ein Humusprofil entnommen und L-, Of- und Oh-Auflage getrennt angesprochen und deren Mächtigkeit erfasst. Am selben Standort erfolgten am Bohrstockeinschlag die Erfassung der Mächtigkeit der Bodenhorizonte und die Ansprache des Bodentyps.

\section{Strahlung}

Der relative Anteil an direkter Strahlung auf den Probeflächen im Vergleich zu einer unbestockten Freifläche (direct site factor - DSF) wurde durch Hemisphärenfotografie geschätzt. Bei gleichmäßig bedecktem Himmel wurden, mit einer Objektivhöhe von einem Meter, über jeder der acht Kleinflächen mit Nikon Coolpix 995 mit Fischaugenobjektiv und selbstnivellierendem Stativ digitale Hemisphärenfotos erstellt. 
Die Bilder wurden im Softwareprogramm WinScanopy (Pro 2003d, Regent Instruments) analysiert. Die Festlegung der Grauwert-Schwellenwerte zur Klassifikation der Fotopixel in Himmel- und Kronenbzw. Hangpixel erfolgte manuell über kalibrierte Segmentierung (Wagner 1998, 2001).

\section{Bestand und Totholz}

Als Bestand wurden sämtliche lebenden Bäume ab einer Höhe von 2,0 m auf der Gesamtprobefläche von $500 \mathrm{~m}^{2}$ erfasst. Von jedem Einzelbaum wurde Baumart, Lage auf der Probefläche mit Entfernung und Azimut, Brusthöhendurchmesser, Höhe und das Auftreten von Schadmerkmalen (u.a. Schälschäden, Terminal- und Seitentriebverbiss, Wind-/Schneebruch, Befall durch Käfer/Pilze) dokumentiert.

Abgestorbene Bäume und Baumteile wurden auf der Gesamtprobefläche von $500 \mathrm{~m}^{2}$ ab einem Durchmesser von $20 \mathrm{~cm}$ am starken Ende und einer Mindestlänge von $50 \mathrm{~cm}$ als Totholz aufgenommen. Von jedem Totholzobjekt wurde Baumart, Lage auf der Probefläche (Entfernung und Azimut von beiden Enden, bzw. von den Punkten, an denen das Totholz den Probekreis verlassen hat), Durchmesser am dicken und am dünnen Ende, Höhe/Länge, Zersetzungsgrad (von 0: im Absterben begriffen bis 5: überwiegend zersetzt) und vermuteter Ausscheidungsgrund dokumentiert.

\section{Jungwuchs}

Abhängig von der Höhe des Jungwuchses wurde dieser auf unterschiedlich großen Aufnahmeflächen innerhalb der $500 \mathrm{~m}^{2}$-Probefläche erhoben. Keimlinge und Anwuchs (bis $20 \mathrm{~cm}$ Höhe, small regeneration) wurde auf den acht $1 \mathrm{~m}^{2}$-großen Kleinflächen erfasst, Aufwuchs (20-50 cm Höhe, medium regeneration) auf 52,99 $\mathrm{m}^{2}$ (50 $\mathrm{m}^{2}$ innerhalb 3,99 m Radius um Probeflächenmittelpunkt und darüber hinausragende Fläche der Kleinflächen 1, 3, 5 und 7) und Aufwuchs (50-200 cm Höhe, large regeneration) auf $150 \mathrm{~m}^{2}$ (siehe Abb. 1.7).

Von jedem Individuum wurden Baumart, Wuchssubstrat, durch Auszählen der Astquirle ermitteltes Alter, Wurzelhalsdurchmesser, Höhe, Höhenzuwachs der vorangegangenen 5 Jahre, das Auftreten von Schadmerkmalen und das vermutete Schadalter dokumentiert.

Standort (mit Ausnahme der Temperatur), Bestand, Totholz und Jungwuchs wurden auf allen 140 Probeflächen während der Vegetationsperiode 2012 oder 2013 erfasst. Methodik und Ergebnisse der Auswertung sind vorwiegend im Artikel in Kapitel 2 publiziert. 


\section{Flora}

Die einmalige Kartierung der Gefäßpflanzen erfolgte zwischen Juni und August 2012 und 2013 nach der Methode von Braun-Blanquet (1964) als Vollaufnahme auf den $500 \mathrm{~m}^{2}$-Probeflächen. Zusätzlich wurden die acht $1 \mathrm{~m}^{2}$-Kleinflächen (siehe Abb. 1.7) zur Erfassung der räumlichen Verteilung der Bodenvegetation und des Einflusses der Bodenvegetation auf die Naturverjüngung separat kartiert. Die Gefäßpflanzen wurden auf 102 Probeflächen erfasst (siehe Abb. 1.5).

\section{Fauna}

Die Erfassung verschiedener faunistischer Artengruppen erfolgte während der Vegetationsperiode von Mai bis September 2012 durch die Nutzung von jeweils zwei Barber- und einer Fensterfalle je Probefläche. Die Fallen wurden monatlich geleert und folgende Artengruppen durch die genannten Experten auf Artniveau bestimmt: Käfer (Coleptera; Alexander Szallies), Wanzen (Heteroptera; Martin Goßner), Stechimmen (Aculeata; Johannes Voith), Spinnen (Arachnida: Araneae; Theo Blick, Arachnida: Opiliones \& Pseudoscorpiones; Christoph Muster), Springschwänze (Collembola; Jörg Salamon) und Mollusken (Mollusca; Christian Strätz). Die Erfassung der verschiedenen faunistischen Artengruppen erfolgte auf jeweils drei der sechs Wiederholungen je Variante (excl. Probeflächen von Fragestellung IV), auf insgesamt 51 Probeflächen (siehe Abb. 1.5).

\section{Fungi}

Die Kartierung der totholzbesiedelnden Pilze erfolgte in einer dreiwöchigen Aufnahmekampagne im August und September 2013. Die makroskopische Erhebung der Fruchtkörper wurde durch die Artspezialisten Peter Karasch und Andreas Gminder zeitstandardisiert mit 90 Minuten Kartierungszeit je Probefläche durchgeführt. Erfasst wurden Pilzart, Wuchssubstrat und Deckung. Die Bestimmung auf Artniveau erfolgte im Gelände oder im Labor. Die Kartierung der totholzbesiedelnden Pilze wurde, wie für die faunistischen Artengruppen, auf jeweils drei der sechs Wiederholungen je Variante (excl. Probeflächen von Fragestellung IV), auf insgesamt 51 Probeflächen ausgeführt (siehe Abb. 1.5).

Details zur Methodik der Erfassung und Auswertung von Gefäßpflanzen, faunistischen Artengruppen und totholzbesiedelnden Pilzen, sowie die dazugehörigen Ergebnisse sind in den Artikeln der Kapitel 3 und 4 publiziert. 


\section{Auswerteverfahren}

Die Auswertung geographischer Informationen und die Erstellung kartographischer Darstellungen erfolgten in ArcGIS 10.0 (ESRI, Kanada). Sämtliche statistischen Auswertungen und die Mehrzahl der Graphiken wurden in R 3.1.0 (R Core Team 2013) unter Nutzung zusätzlicher Erweiterungspakete erstellt.

Eine ausführliche Darstellung der Auswertungsmethodik der Forschungsfragen I bis III ist in den Kapiteln 2 bis 4 dokumentiert. Im Folgenden wird lediglich ein kurzer Überblick über die genutzten Methoden skizziert und auf die Auswertungsschritte für die Forschungsfragen IV (Einfluss der Flächenausdehnung des Borkenkäferbefalls auf die Verjüngung) und V (Einfluss der Flächenräumung auf Verjüngung und Artenvielfalt) eingegangen.

I. Welche standortspezifischen Veränderungen ergeben sich durch den Borkenkäferbefall in den Waldbeständen?

Humus- und Bodenparameter, Strahlung, Temperaturschwankungen, Dauer der Schneebedeckung und der Vegetationsperiode, Bestandesvolumen, räumliche Verteilung des Bestandes und Entfernung potentieller Samenbäume wurden mit mehrfachen Wiederholungstests (resampling-based multiple scaling) und Tukey-post-hoc-Test auf signifikante Unterschiede zwischen den Sukzessionsstadien und Höhenstufen getestet (Kapitel 2).

II. Welchen Einfluss haben diese Veränderungen auf die Verjüngung und wie läuft diese ab?

Zur Ermittlung der vom Jungwuchs präferierten Keimsubstrate wurden potentiell zur Verfügung stehende und tatsächlich als Keimbett genutzte Substrate gegenübergestellt. Um den Einfluss der gemessenen Standortparameter auf Baumartenzusammensetzung und Jungwuchsdichten zu ermitteln, wurde der Jungwuchs der fortschreitenden Sukzession mittels nicht-metrischer multidimensionaler Skalierung (NMDS) ordiniert und zu den mit der Ordination korrelierenden Kovariablen in Beziehung gesetzt. Signifikante Unterschiede in den Jungwuchsdichten zwischen den drei Sukzessionsstadien wurden mit mehrfachen Wiederholungstests und Tukey-post-hoc-Test ermittelt. Eine Gegenüberstellung von Keimzeitpunkt der Jungwuchs- und Bestandesindividuen der beginnenden und fortschreitenden Sukzession und Zeitpunkt der Störung ermöglichte die Berechnung des Anteils an Vorausverjüngung (advance regeneration) (Kapitel 2). 
III. Welche Konsequenzen ergeben sich durch die veränderten Standortverhältnisse für die Artenzusammensetzung und Artenvielfalt von verschiedenen Artengruppen von Pflanzen, Tieren und Pilzen?

Die untersuchten Artengruppen wurden entsprechend ihrer ökologischen Ansprüche in folgende funktionelle Gruppen unterteilt: Primärproduzenten (autotrophs), Bodenbesiedler (epigeics), Pflanzenfresser (phytophagous), Bestäuber (pollinators) und Totholzbesiedler (saproxylics) und auf signifikante Unterschiede der Artenzahlen (Alpha-Diversität) zwischen den drei Sukzessionsstadien getestet. Durch Artensättigungskurven (species accumulation curve) wurden die Artenzahlen auf mögliche Verzerrungen durch unterschiedliche Abundanzen (Anzahl der beobachteten Individuen einer Art) überprüft. Eine Auswertung der mittleren Ellenberg-Indikatorwerte für Licht- und Stickstoff der Gefäßpflanzen und eine Indikatorarten-Analyse (Indicator Species Analysis) aller Artengruppen diente der Analyse möglicher Änderungen der Artenzusammensetzung im Verlauf der Sukzession. Zusammenhänge zwischen Standortparametern und Artenzahlen der verschiedenen Artengruppen wurden mittels Rangkorrelation (Spearman rank correlation) getestet (Kapitel 3).

Zusätzlich wurde die Beta-Diversität bzgl. Artenzusammensetzung, phylogenetischer und funktioneller Vielfalt für Gefäßpflanzen, totholzbesiedelnde Pilze und totholzbesiedelnde Käfer mit mehrfachen Wiederholungstests (resampling-based multiple scaling, Westfall und Young 1993) und Tukey-post-hoc-Test auf signifikante Unterschiede zwischen den drei Sukzessionsstadien untersucht. Durch nicht-metrische multidimensionale Skalierung (NMDS, Legendre und Legendre 1998) wurden die Zusammenhänge zwischen Artenzusammensetzung und Bestandesstrukturen analysiert. Die Gamma-Diversität der Untersuchungsflächen wurde durch Extrapolation der Artenzahlen geschätzt (Kapitel 4).

IV. Welchen Einfluss hat die Flächenausdehnung des Borkenkäferbefalls auf die Verjüngung in der beginnenden Sukzession?

Humusmächtigkeit, Strahlung, Entfernung potentieller Samenbäume, Jungwuchsdichten, Baumartenanteile und Höhenzuwachs wurden mit mehrfachen Wiederholungstests (resamplingbased multiple scaling, Westfall und Young 1993) und Tukey-post-hoc-Test auf signifikante Unterschiede zwischen den Aufnahmepositionen (Nord-, Ost-, Süd-, Westrand, Mittelbereich) innerhalb der großen Störungsflächen der beginnenden Sukzession und auf signifikante Unterschiede zwischen standörtlich vergleichbaren Befallsflächen $<1$ ha und $>1$ ha getestet (Funktion oneway-test in Zusatzpaket coin). Gegenübergestellt wurden die 38 Probeflächen der sechs Befallsflächen $>1$ ha mit den 18 Probeflächen der beginnenden Sukzession in montan bis subalpiner schattseitiger Lage auf Befallsflächen $<1$ ha. Bei direktem Vergleich zwischen großen und kleinen Befallsflächen wurden 
die einzelnen Probeflächen der verschiedenen Aufnahmepositionen in den großen Befallsflächen zunächst gemittelt um eine Verzerrung der Ergebnisse durch Pseudoreplikation aufgrund des gruppierten Probeflächendesigns zu vermeiden, ebenso wurden die Daten bei mehreren Probeflächen in mittlerer Position vor weiteren Berechnungsschritten gemittelt. Die Auswertung des Höhenzuwachses basiert auf Messungen des Höhenzuwachses des Jahres 2011 an knapp 800 Fichtenjungwüchsen ohne Terminaltriebverbiss. Der Jahrestrieb von 2011 war bei den Aufnahmen im Sommer 2012 vollständig verholzt und war auf allen Probeflächen unter den bereits bestehenden Bedingungen der Lückensituation entstanden. Die Ergebnisse greifen nicht auf die Resultate der Bachelorarbeit von Karin Beer und Tobias Wiepcke zurück (Beer und Wiepcke 2014), sondern stellen eigenständige erweiterte Auswertungen dar (Kapitel 5).

V. Welchen Einfluss übt Flächenräumung und unterstützende Pflanzung im Maßnahmenbereich Borkenkäferbekämpfung auf Verjüngung und Artenvielfalt in der beginnenden Sukzession aus?

Standort- und Bestandesattribute, Baumartenzusammensetzung und Jungwuchsdichten wurden mit mehrfachen Wiederholungstests (resampling-based multiple scaling, Westfall und Young 1993) und Tukey-post-hoc-Test (Funktion oneway-test in Zusatzpaket coin), die Artenzahlen der untersuchten funktionellen Artengruppen mit Quasi-Poisson-Modellen und Post-hoc-Test (Funktion $\mathrm{g} / \mathrm{m}$ in Zusatzpaket multcomp, siehe auch Methodik in Kapitel 3) auf signifikante Unterschiede zwischen den Probeflächen der beginnenden Sukzession innerhalb und außerhalb des Maßnahmenbereichs Borkenkäferbekämpfung in montaner schattseitiger Lage getestet (NMN_R_01-06 vs. NMN_01-06). Die unterschiedlichen Artenzusammensetzungen wurden als Venn-Diagramm interpretiert (Kapitel 5). 


\section{Probeflächenübersicht}

Wesentliche Standortattribute der 140 Probeflächen sind in den Tabellen 1.2 bis 1.5 zusammengefasst. Inhaltlich stehen diese, mit dem Vorgriff auf Teilergebnisse dieser Studie, zwischen Methoden- und Ergebnisteil. Da die vier Ergebnis-Kapitel durch unterschiedliche Fragestellungen auf verschiedenen Teilgesamtheiten der 140 Probeflächen basieren und keine Gesamtübersicht liefern, scheint diese Darstellung für die Gesamteinordnung der nachfolgenden Ergebnisse jedoch als wesentlich.

Die dreistellige Buchstaben-Kodierung der Probeflächen in Störungsflächen $<1$ ha (Tabellen 1.2-1.4) beschreibt an erster Stelle das jeweilige Entwicklungsstadium (Referenz: Fichtenaltbestand, Neu: beginnende Sukzession, Alt: fortschreitende Sukzession), an zweiter Stelle die Höhenstufe (Montan: ca. 700-1.200 m ü. NN, Hochmontan: ca. 1.200-1.400 m ü. NN, Subalpin: >1.400 m ü. NN), und an dritter Stelle die Exposition (Nord: schattseitig, 292,5 $-112,5^{\circ}$, Süd: sonnseitig, $112,5^{\circ}-292,5^{\circ}$ ). Die Buchstaben-Kodierung der Probeflächen in Störungsflächen $>1$ ha (Tabelle 1.5) beschreibt Höhenstufe, Gebiet (Klausbachtal, Watzmann, Priesberg) und Lage innerhalb der Störungsfläche (Nord-, Ost-, Süd- Westrand und Mittelfläche).

Nach Anlage der ersten Probeflächen im Frühjahr 2012 kam es in zwei Fällen auf den in Fichtenaltbeständen angelegten Probeflächen zu Borkenkäferbefall. Die Daten dieser Flächen wurden in keine Auswertungen integriert, stattdessen wurden Aufnahmen in Ersatz-Probeflächen unbefallener Fichtenaltbeständen durchgeführt und für die Auswertung herangezogen (Tabelle 1.2, _Ersatz). Vereinzelt kam es nach Anlage von Probeflächen in Störungsflächen der beginnenden Sukzession zur weiteren Ausbreitung des Borkenkäferbefalls, so dass die Störungsflächen die ursprüngliche Flächenausdehnung von maximal einem Hektar nach Abschluss der Aufnahmen teilweise überschritten haben (Tabelle 1.3, Flächenausdehnung $>10.000 \mathrm{~m}^{2}$ ). 


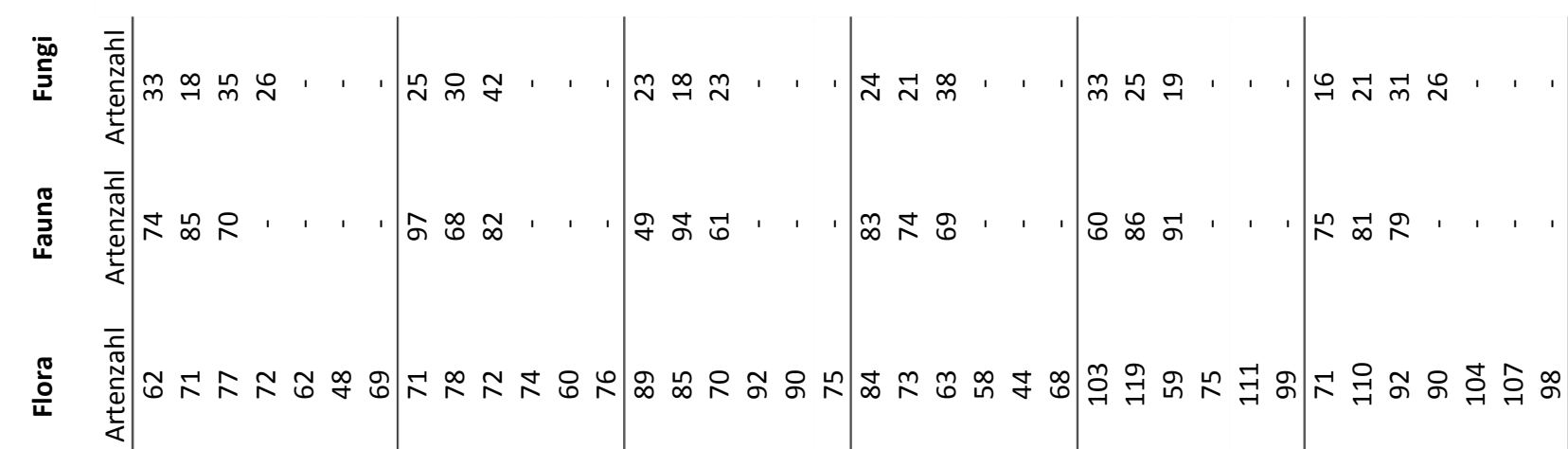

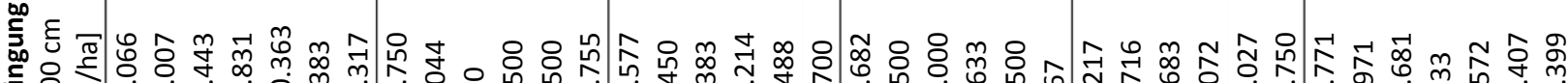
事家

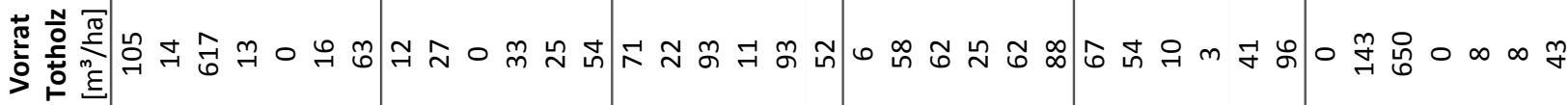
范焉离

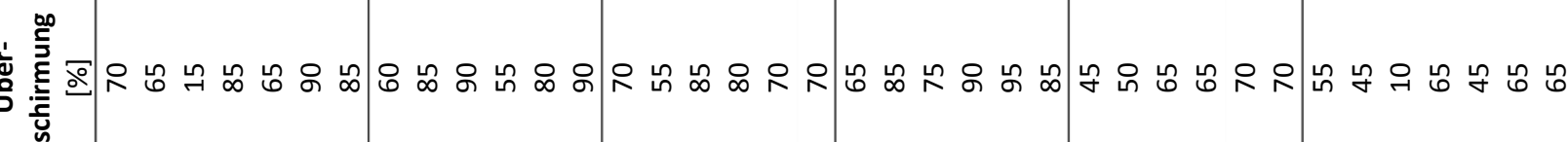

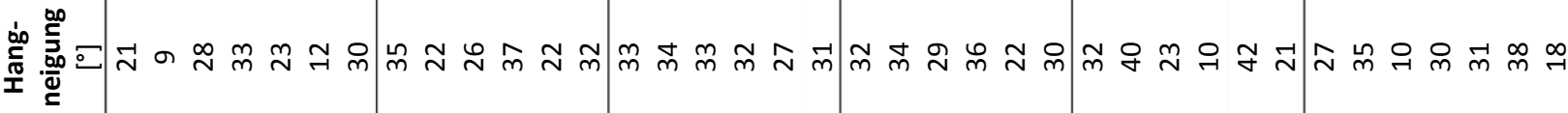

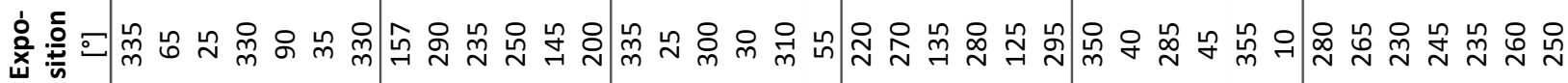

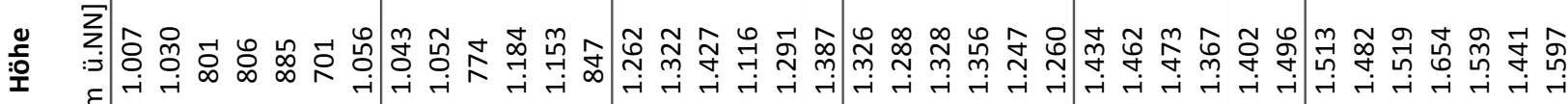

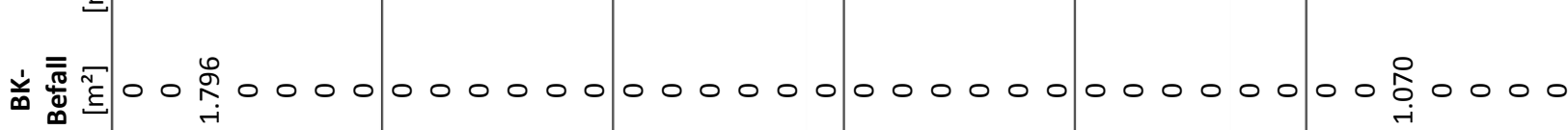

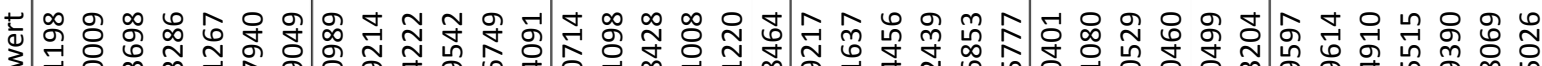

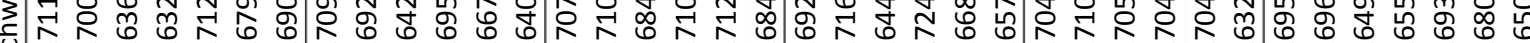

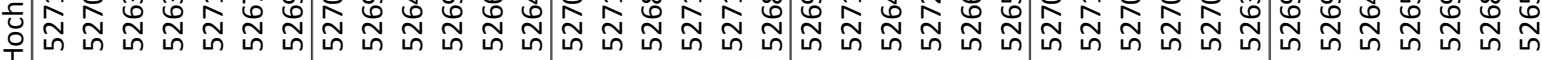

请定

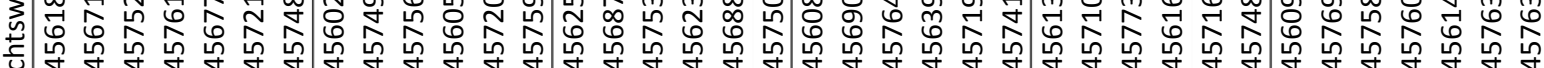
$\approx$

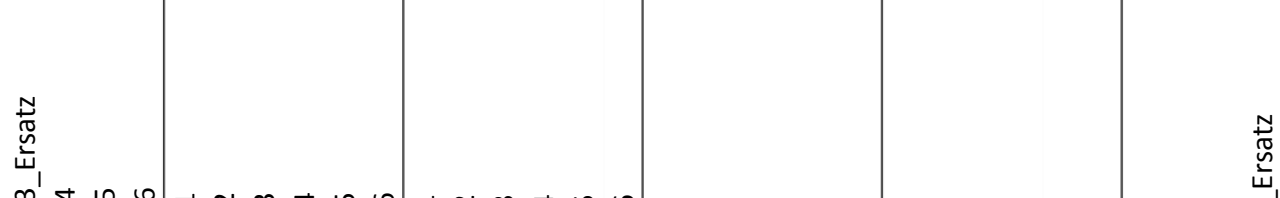

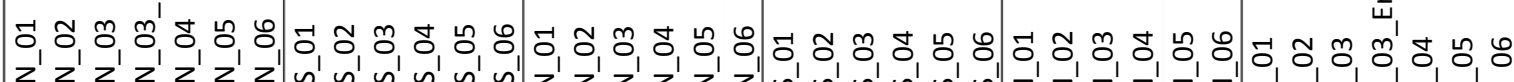

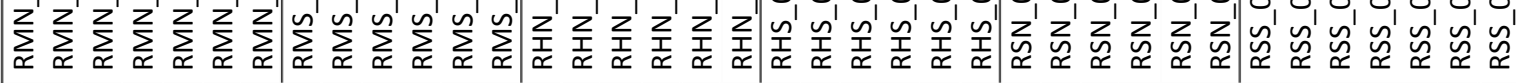

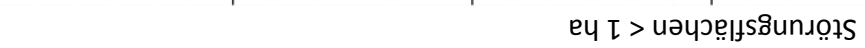

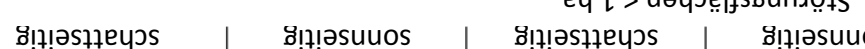

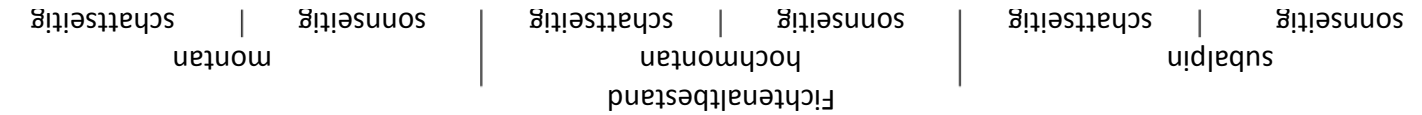




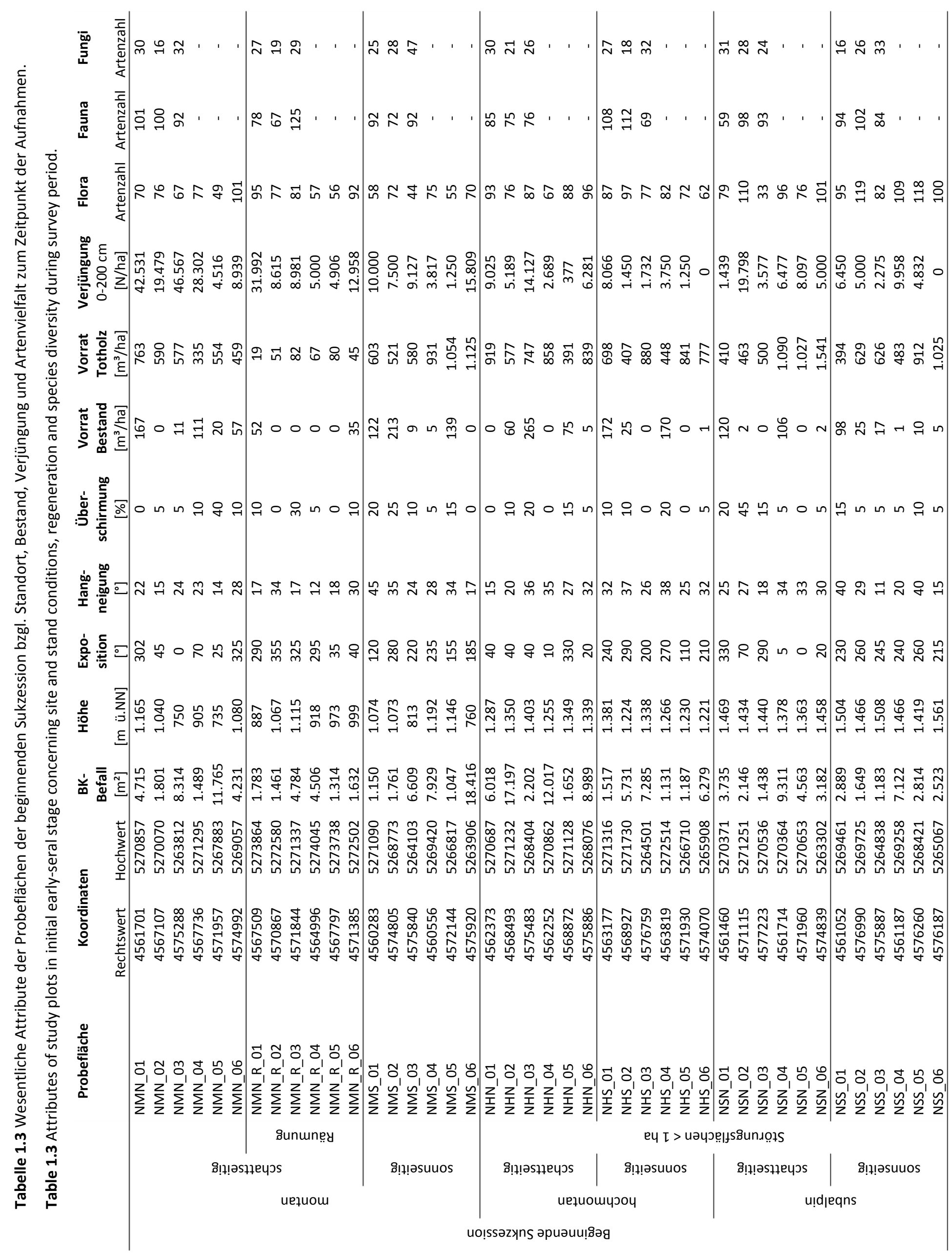




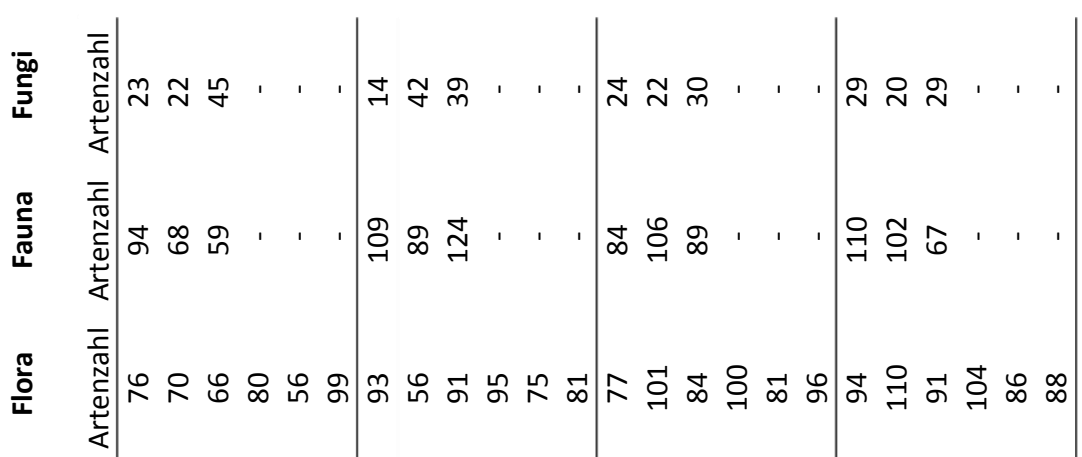

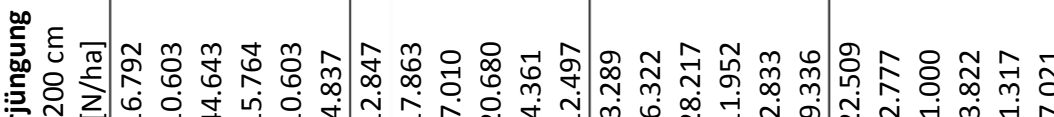
帚家

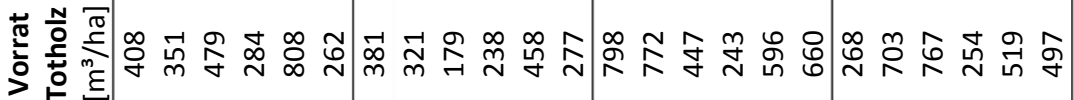

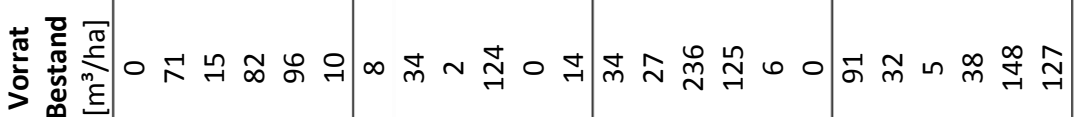

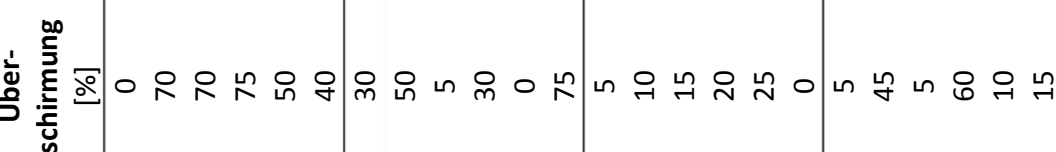

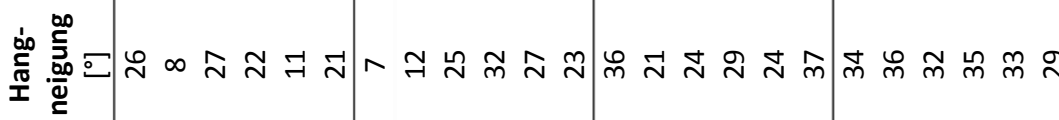

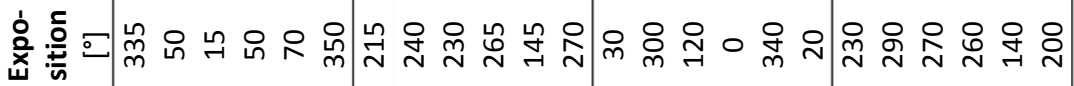

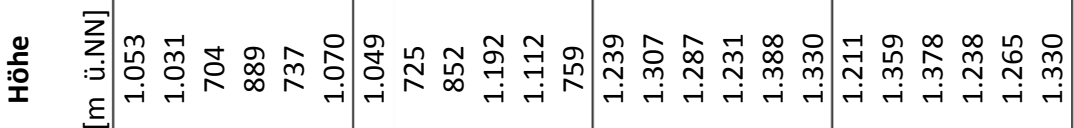

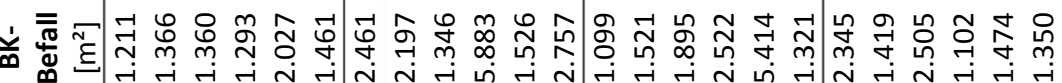

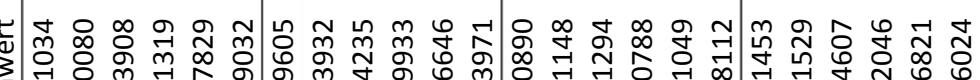

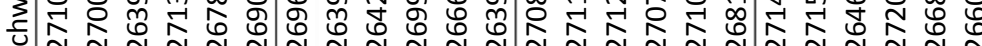

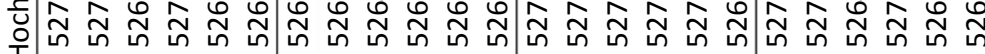

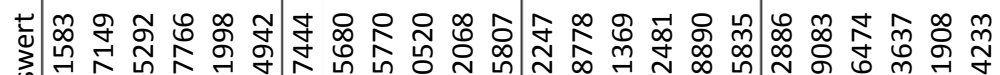

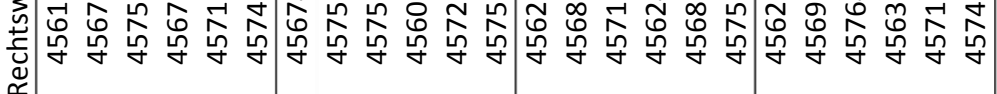

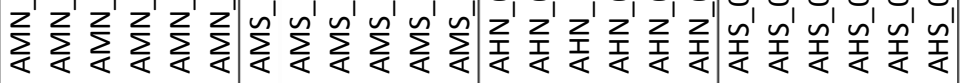

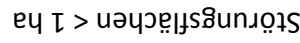

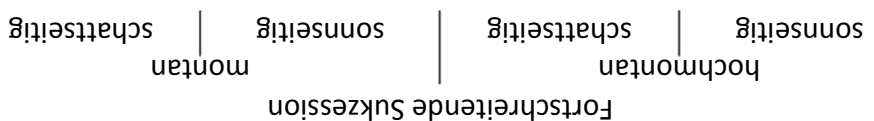




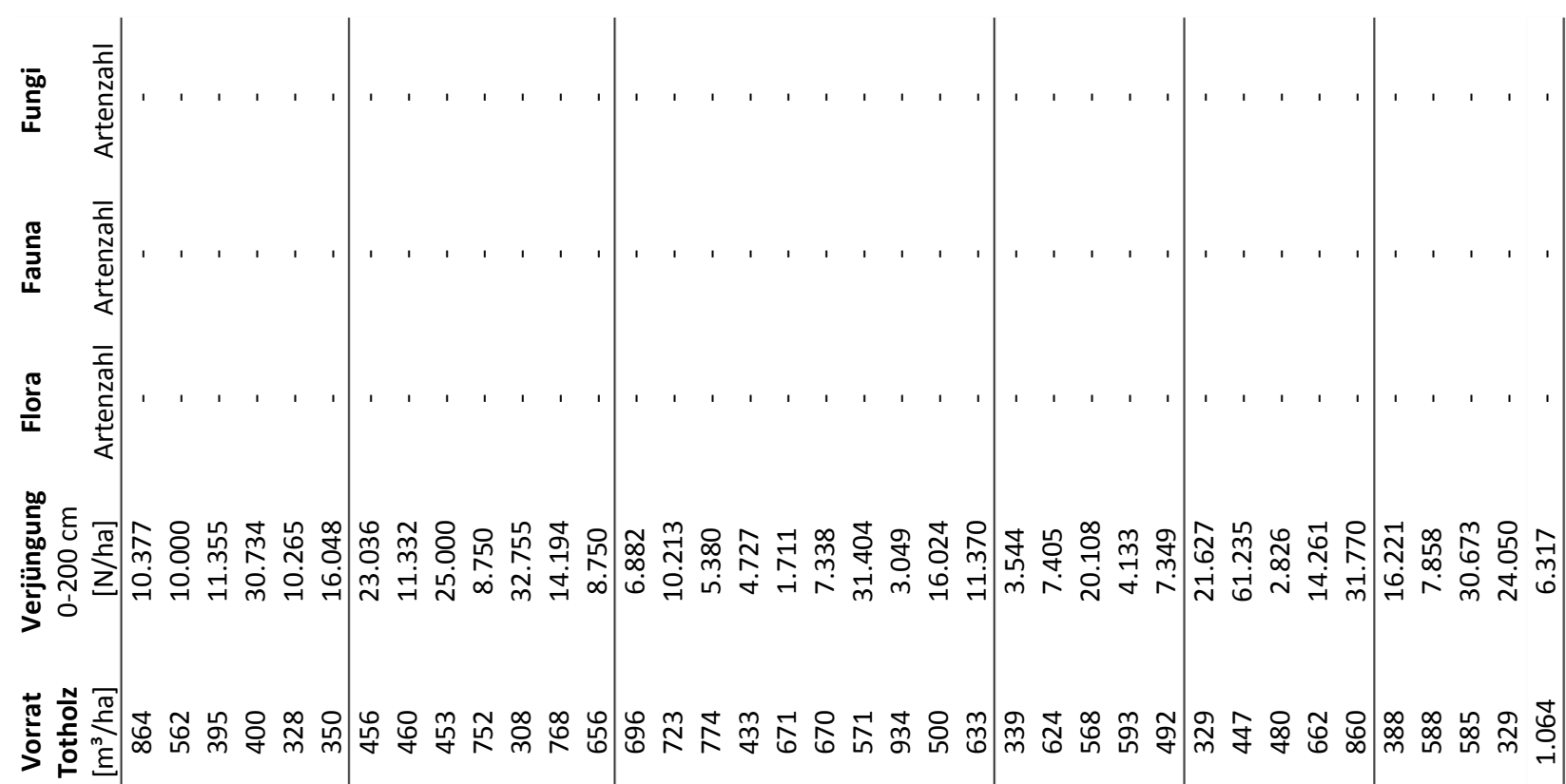

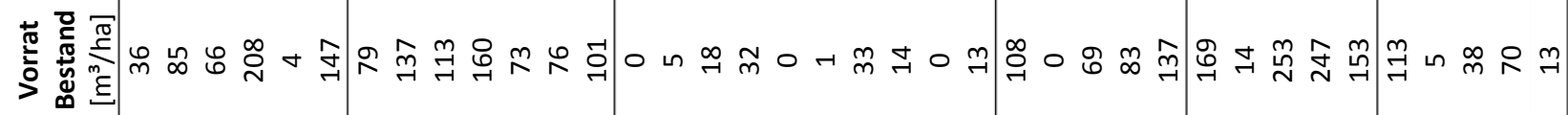

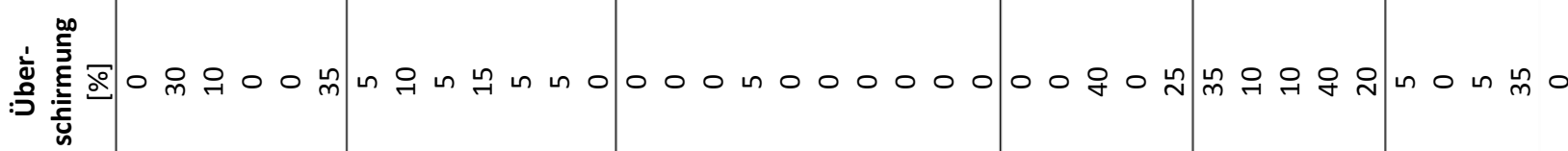

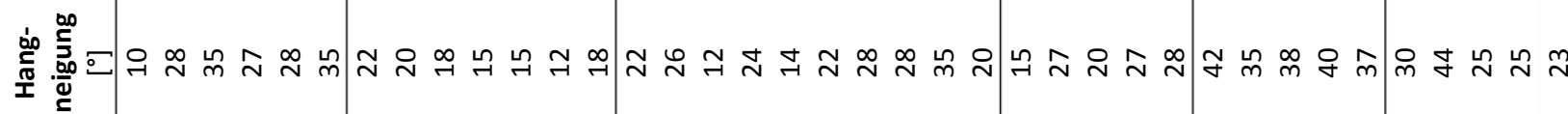

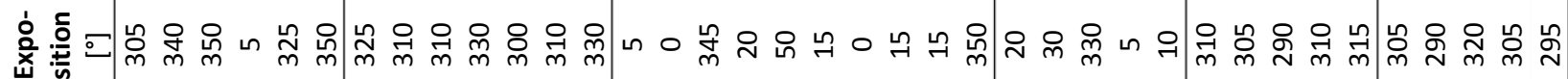

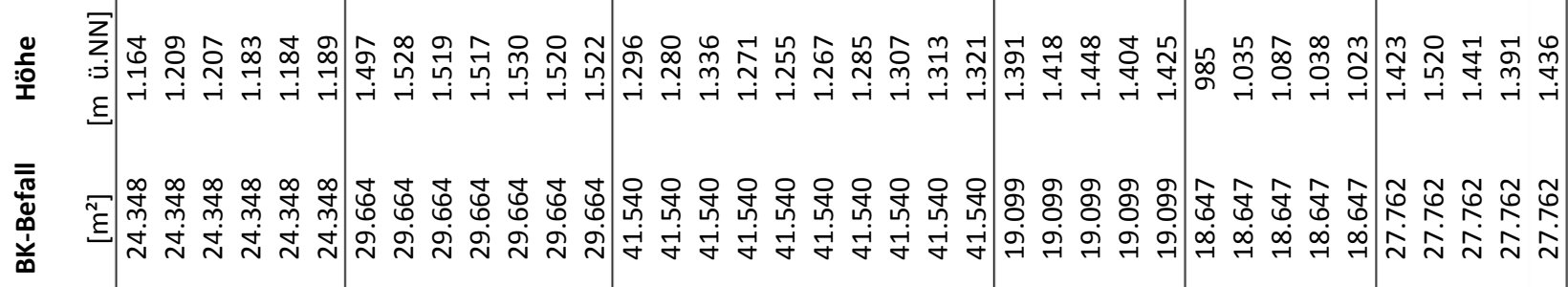

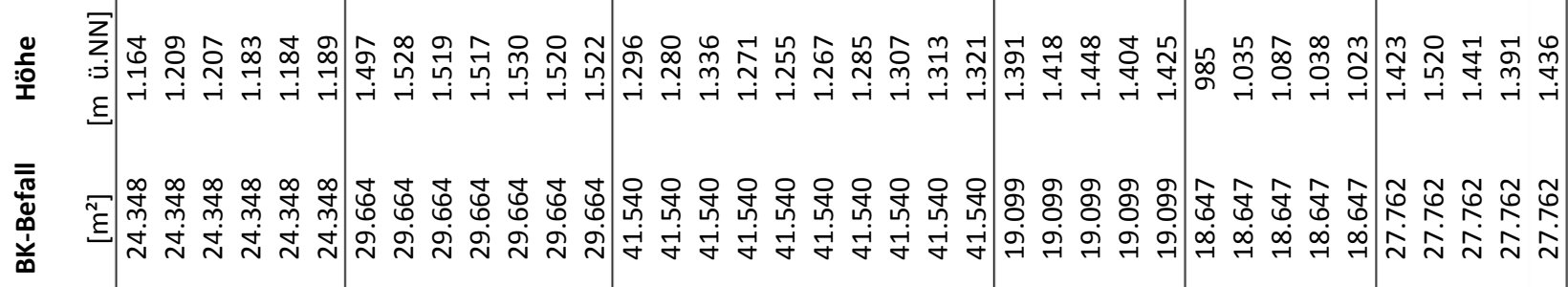

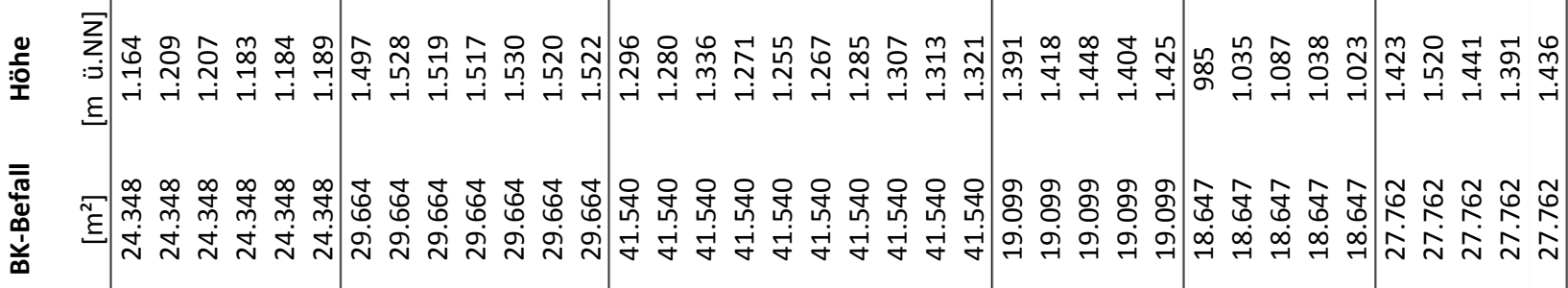

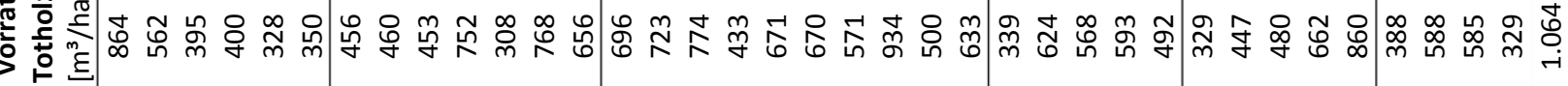

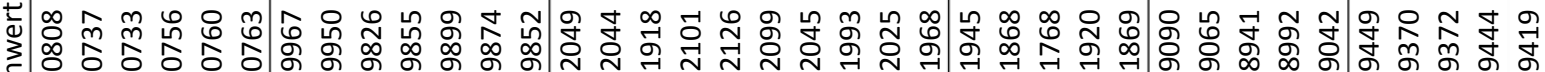

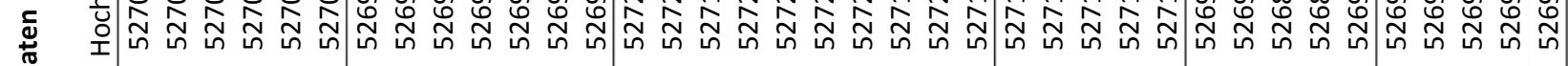
产

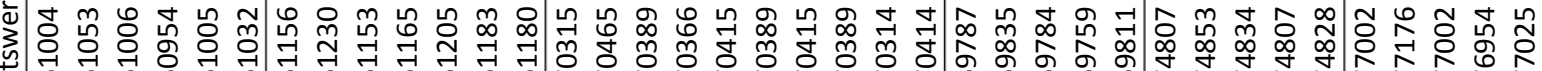

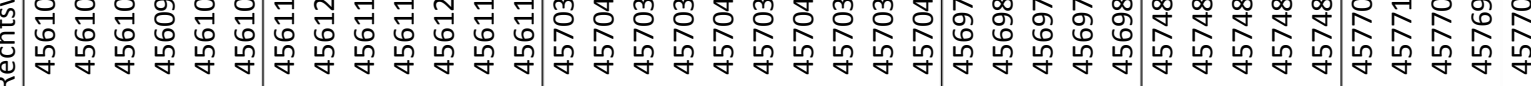

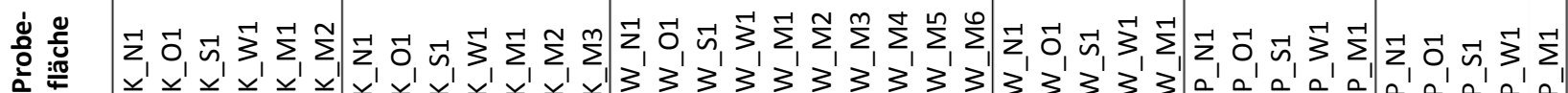

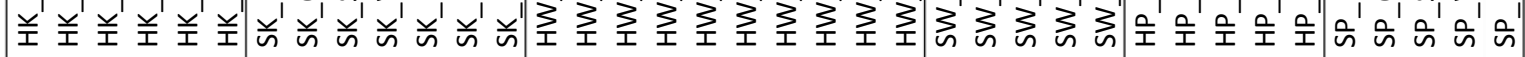

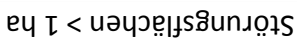

uezuomyวoч | u!djeqns

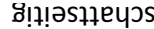
uezuomyjoy $\mid$ u!djeqns uo!ssəzyns әрuәuu!øəg uełuom u!djeqns 


\section{Kapitel 2}

\section{Regeneration dynamics and resilience of unmanaged mountain forests in the Northern Limestone Alps following bark beetle- induced spruce dieback}

Winter, M.-B., Baier, R., Ammer, C. $^{1}$

European Journal of Forest Research (2015) 134: 949-968.

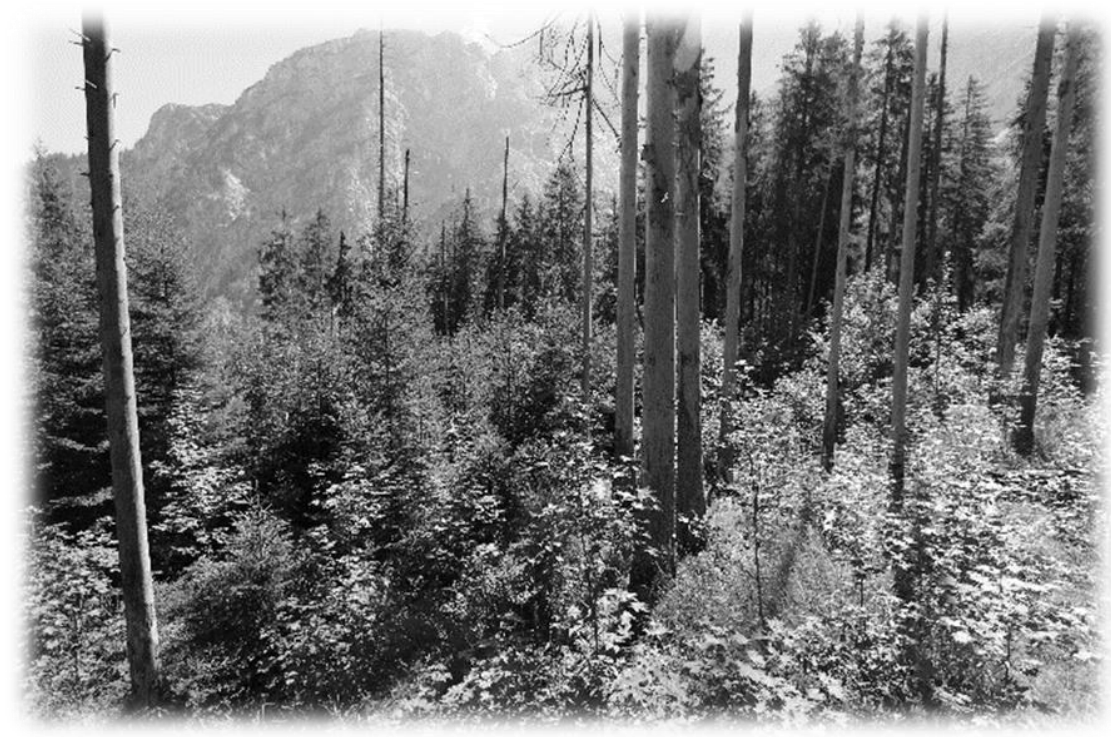

Stadium der fortschreitenden

Sukzession mit Jungwuchs aus Gemeiner Fichte und Bergahorn im Wimbachtal, 20 Jahre nach Borkenkäferbefall (Foto: H. Maltan).

1 Maria-Barbara Winter war für die Datenaufnahme, die Auswertung der Daten, die Aufbereitung der Ergebnisse und die Erstellung des Manuskripts verantwortlich. Roland Baier und Christian Ammer betreuten Datenauswertung und Manuskripterstellung.

Die Publikation ist hier um deutsche Übersetzungen des Titels und der Über- bzw. Unterschriften von Tabellen und Abbildungen erweitert. 


\title{
Regeneration dynamics and resilience of unmanaged mountain forests in the Northern Limestone Alps following bark beetle induced spruce dieback
}

\section{Verjüngungsdynamik und Resilienz unbewirtschafteter Bergwälder in den Nördlichen Kalkalpen nach Absterben der Fichtenaltbestände durch Borkenkäferbefall}

\author{
Maria-Barbara Winter ${ }^{a, b *}$, Roland Baier ${ }^{c}$, Christian Ammer $^{a}$ \\ a Department Silviculture and Forest Ecology of the Temperate Zones, Georg-August-Universität \\ Göttingen, Büsgenweg 1, 37077 Göttingen, Germany. Email: mbwinter@gmx.de \\ b Forest Research Institute of Baden-Württemberg (FVA), Wonnhaldestraße 4, 79100 Freiburg, \\ Germany. \\ ${ }^{c}$ Bavarian Office for Forest Seeding and Planting (ASP), Forstamtsplatz 1, 83317 Teisendorf, Germany \\ * Corresponding author
}

\begin{abstract}
Mountain forests provide many important ecosystem services including protection against avalanche and rock fall. These services often depend on a continuity of forest cover and therefore on ecological stability - resistance and resilience to disturbance. Natural regeneration following large-scale disturbance is an important component of forest resilience but in the mountain forests of the Alps is not well understood. This restricts management decision making, particularly in the face of an increased threat to the currently dominant Norway spruce from the bark beetle (Ips typographus). In light of this we analysed bark beetle infestation patterns, forest structure, selected tree regeneration characteristics and species composition on 96 study plots on a chronosequence of bark beetle induced natural forest succession in unmanaged mountain forest ecosystems in southeastern Germany. The most advanced plots were twenty years on from the bark beetle induced dieback of mature Norway spruce and the majority were already quite densely stocked. The regeneration was clustered and was dominated by sycamore maple and Norway spruce. Most notably, the proportion of advance regeneration was negligible with the vast majority of the seedlings having germinated after the disturbance event. The findings suggest that these forests are naturally resilient in terms of regeneration if high browsing intensities do not prohibit the establishment of new seedlings. The bark beetle outbreaks appear to have generated an acceleration of development away from human influenced pure Norway spruce forests towards a more natural species composition. Nevertheless, Norway spruce will remain the dominant species for at least the next generation. These findings are important for managers intending to uphold protective forest functions. The integration of naturally
\end{abstract}


evolving gaps as elements which diversify environmental conditions on the forest stand level as well as on the landscape scale is recommended for close-to-nature forest management.

Keywords: Natural disturbances, Ips typographus, Natural regeneration, Microsite, Forest succession, Berchtesgaden National Park.

\section{Zusammenfassung}

Bergwälder erfüllen zahlreiche wichtige Funktionen, u.a. Schutzfunktionen gegenüber Lawinen und Steinschlag. Der Erfüllungsgrad der Waldfunktionen hängt jedoch meist an der dauerhaften Bestockung der Waldbestände und damit an deren ökologischer Stabilität - Widerstandskraft und Resilienz - gegenüber Störungen. Wesentlichster Faktor der Resilienz nach großflächigen natürlichen Störungen ist der Naturverjüngungsprozess. Zeitlicher Verlauf und relevante Einflussgrößen dieses Prozesses sind in den Bergwäldern der Alpen jedoch erst ansatzweise bekannt. Die Wissensdefizite können die forstliche Entscheidungsfindung, insbesondere im Hinblick auf die zunehmende Gefährdung der derzeit dominierenden reinen Fichtenbestände durch Borkenkäferbefall (von Ips typographus), erschweren. Diese Studie untersuchte daher die Verbreitungsmuster des Borkenkäferbefalls in den unbewirtschafteten Wäldern des Nationalparks Berchtesgaden im Südosten Deutschlands. Darüber hinaus wurden auf 96 Probeflächen in verschiedenen Entwicklungsstadien vor und nach Borkenkäferbefall Bestandesstrukturen, natürliche Verjüngung und Baumartenzusammensetzung analysiert. Die am weitesten in der natürlichen Sukzession fortgeschrittenen Flächen befanden sich zum Zeitpunkt der Aufnahmen 2012/13 etwa zwanzig Jahre nach dem durch den Borkenkäferbefall ausgelösten Absterben der Fichtenaltbestände und waren bereits überwiegend dicht bestockt. Der vorhandene Jungwuchs trat räumlich geklumpt auf den Probeflächen auf und war von Gemeiner Fichte und Bergahorn dominiert. Wider Erwarten war der Großteil des vorhandenen Jungwuchses erst nach dem Störungsereignis gekeimt. Der Anteil an Vorausverjüngung war verschwindend gering. Die Ergebnisse lassen erkennen, dass diese Wälder natürlicherweise eine hohe Resilienz aufweisen, so lange das Aufkommen des Jungwuchses nicht durch hohe Wildbestände gefährdet wird. Es zeigt sich auch, dass der Borkenkäferbefall die Entwicklung von sekundären Fichtenwäldern hin zu einer naturnaheren Baumartenzusammensetzung beschleunigen kann. Nichts desto trotz wird die Gemeine Fichte auch in den nächsten Baumgenerationen die dominierende Baumart in diesen Beständen sein. Dies sind wichtige Erkenntnisse zum Erhalt der Schutzwaldfunktionen in störungsbeeinflussten Waldgebieten. Wir empfehlen der forstlichen Praxis natürlich entstehende Lücken, die sowohl auf Bestandes- als auch auf Landschaftsebene die Strukturvielfalt erhöhen, soweit aus Forstschutzbelangen möglich, in die naturnahe Waldbewirtschaftung zu integrieren. 
Schlagwörter: Natürliche Störungen, Ips typographus, Naturverjüngung, Kleinstandort, Waldsukzession, Nationalpark Berchtesgaden

\section{Introduction}

Natural disturbances such as strong winds, insect outbreaks and wildfire are a central component of forest dynamics (Attiwill 1994; Franklin et al. 2002; Ellenberg and Leuschner 2010), that have gained increasing importance in European forests during the twentieth century (Schelhaas et al. 2003; Seidl et al. 2014; Kärvemo et al. 2014). Between 1950 and 2000 bark beetle outbreaks alone (Curculionidae: Scolytinae, mainly Ips typographus L. and Pityogenes chalcographus L.) caused mortality of about 2.9 million $\mathrm{m}^{3}$ wood per year in European forests (Schelhaas et al. 2003). Furthermore, the impact of natural disturbances including bark beetle outbreak, is likely to increase in the coming decades (Seidl et al. 2014). While the reasons are diverse, management-related stand conditions and changing climatic conditions have been determined as key drivers of this development (Seidl et al. 2011). Over much of Europe, many formerly mixed forests were replaced during the $19^{\text {th }}$ and $20^{\text {th }}$ century by homogenous stands consisting purely or predominantly of Norway spruce (Picea abies (L.) Karst). Especially in the Alps, centuries of intensive timber extraction (e.g. due to salt mining) and intentionally high ungulate populations heavily altered the forest structure and composition (Knott et al. 1988). The majority of these stands have now become more susceptible to disturbances from wind or insect outbreaks than the forests they replaced (Seidl et al. 2011). This is compounded by a changing climate in two ways: Firstly bark beetle habitats are created at higher latitudes and elevations which were previously unsuitable (Krehan and Steyrer 2006; Seidl et al. 2009). In addition, the associated increase in frequency and intensity of extreme weather events such as storms and drought periods (e.g., Frich et al. 2002; Beniston et al. 2007), results in damaged stands which are predisposed to bark beetle outbreak (Hartl-Meier et al. 2014; Overbeck and Schmidt 2012).

Many ecosystem services provided by mountain forests such as protection from erosion and avalanches, carbon sequestration, and timber production, depend on the continuity of stable forest stands (Otto 1994). The stability of an ecosystem in relation to disturbances can be characterized by the concepts of resistance and resilience (Kräuchi et al. 2000; Brang 2001; Dorren et al. 2004). Here resistance is defined as 'staying essentially unchanged despite the presence of disturbing agents' (Grimm and Wissel 1997), while resilience refers to the ability to return to a reference state after a disturbance (Dorren et al. 2004). Various studies have developed ideas to improve the resistance of mountain forests against disturbances such as windthrow, insect calamities or climatic extremes over the last decades (e.g., Papaik and Canham 2006; Bruelheide and Luginbühl 2009; Höllerl 2009a). However, for the present generation of untended secondary spruce forests these ideas have been of 
very limited success. Growing interest is thus directed towards understanding resilience of European mountain forest ecosystems.

Successful regeneration is regarded as a key component of forest resilience (Brang 2001; Höllerl 2009a). On the whole, forest management has proactively supported natural regeneration through strategic thinning, harvesting or hunting measures (Ammer 1996a; Brang 2001; Frehner et al. 2005; Höllerl 2009a; Prietzel 2010; Ammer et al. 2010). It has been shown that successful natural regeneration after large disturbances - being natural in the case of bark beetle infestations or anthropogenic in the case of heavy harvesting activities - strongly depends on the presence of advance regeneration i.e. seedlings being present before the disturbance of the overstorey takes place (Bauer 2002; Rammig et al. 2006; El Kateb et al. 2009; Wild et al. 2014). The rapid large-scale mortality of mature trees during natural disturbance events leads to open, early-seral systems with significant changes in site conditions. These may include higher solar radiation at the forest floor, more extreme temperatures, accelerated nutrient fluxes in the soil, and increased cover and height of the understory vegetation (Roberts 2004; Swanson et al. 2011; Donato et al. 2012). The latter can prohibit or at least delay a successful natural regeneration (Ammer 1996b; Brang et al. 2003; Ammer et al. 2011) and thereby hinder the continuation of important forest functions such as protection against natural hazards. In mountain forests, early establishment of tree species is strongly linked to specific microsites and substrates, namely thick humus layers and decomposed logs or other protected or elevated positions (see Ammer 1998; Brang et al. 2003; Baier et al. 2007). We expect that these "safe sites" gain extended importance under the harsher post-disturbance conditions, such as increased temperature extremes, intensified competition by ground vegetation and snow gliding.

In the European Alps, primary forests are almost non-existent (Ellenberg and Leuschner 2010) and thus opportunities to study the effects of disturbance on the structure, regeneration and stability of natural forests are rare. Many European forests, even those which are now protected, have seen periods of intensive management and often over-utilization (Pechmann 1932; Meister 1969; Knott et al. 1988; Wäldchen et al. 2011). However, it has been shown that under certain conditions they can develop along a trajectory from homogenous secondary stands towards a structure and composition more characteristic of old-growth forests (Meyer 2013). Natural disturbances could even accelerate this process (Müller et al. 2008) if for example, mother trees of mixed species are present and ungulate density allows seedling growth. The time scale of this process and the extent of success in changing stand composition and structure have yet to become clear.

Although most of the stands in presently protected areas have a history of management intervention, they are still valuable in the study of forest development following the transition to 
unmanaged status. This is of interest from a scientific point of view as studies focusing on natural dynamics following large-scale disturbances in mountain forests are scarce in the literature to date (Schönenberger 2002; Kupferschmid et al. 2002; Puettmann and Ammer 2007). It may also provide insights for practical forestry. In many cases silvicultural interventions facilitating the conversion of pure secondary forests to mixed, more structured woodlands are shown to be cost-effective (Höllerl 2009b). However, where this is not the case, it is useful to explore how the desired change in stand composition and structure can be achieved using naturally occurring processes.

In view of the above, this study addresses natural succession of pure Norway spruce stands following bark beetle outbreak in the alpine National Park of Berchtesgaden in southeastern Germany. We studied 96 stands all of which had been anthropogenically altered in the past, but had been unmanaged for at least 35 years. We investigated the following three hypotheses:

(I) Site conditions change considerably through bark beetle induced spruce dieback, but do not hinder natural regeneration processes.

(II) Regeneration of forest stands does, however, predominately depend on advance regeneration. Regeneration germinating after a disturbance event is restricted to specific microsites.

(III) Bark beetle induced spruce dieback shifts tree species composition and stand structure from structurally homogeneous pure Norway spruce forests towards a more natural highly structured mixed species forest with resulting landscape heterogeneity.

\section{Materials and Methods}

\section{Study area}

The Berchtesgaden National Park, founded in 1978, is located in the southeastern corner of Germany in the Northern Limestone Alps (Fig. 2.1). It covers an area of 20,800 ha with an altitudinal gradient from $603 \mathrm{~m}$ a.s.l. to $2,713 \mathrm{~m}$ a.s.l. (Winter et al. 2015). The mean annual temperature range is $+7^{\circ} \mathrm{C}$ to $-2{ }^{\circ} \mathrm{C}$, and annual precipitation is $1,500-2,600 \mathrm{~mm}$. Mean duration of snow cover increases from approximately 110 days in the valleys to 200 days at $1,500 \mathrm{~m}$ a.s.l. and to 270 days at 2,000 $\mathrm{m}$ a.s.l. (Spandau 1988). Main soil types are rendzic leptosols of intermediate and shallow soil depths, eutric leptosols (humus layer $>15$ to $35 \mathrm{~cm}$ ) on steep slopes, and chromic cambisols on less steep slopes and in valley bottoms.

The natural forest type in the mid-elevation zones of the region is mixed-montane European beech (Fagus sylvatica L.) forests with Norway spruce (Picea abies) and silver fir (Abies alba Mill.). In the higher subalpine zones Norway spruce - European larch (Larix decidua Mill.) - Swiss stone pine 
(Pinus cembra L.) forests occur naturally (Köstler and Mayer 1974). Historically, centuries of high demand for timber from the salt mining industry greatly altered the natural composition in all parts of these forests which were accessible by humans. As Norway spruce ensured better timber floating and even burning conditions, the alterations favored pure Norway spruce stands (Knott et al. 1988; Konnert and Siegrist 2000).

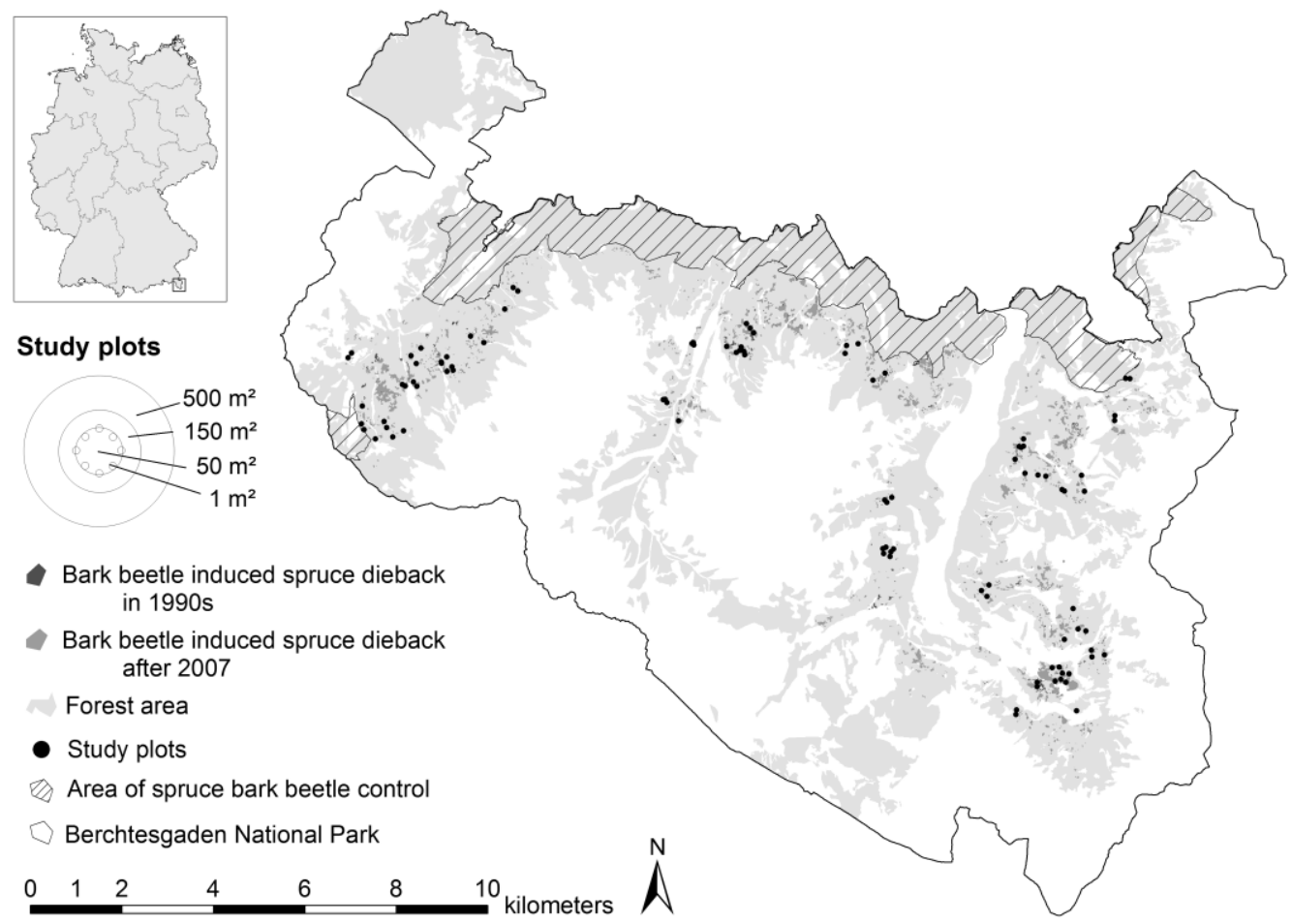

Fig. 2.1 Map of Berchtesgaden National Park showing the spatial distribution of bark beetle gaps and position of the 96 study plots outside the bark beetle management zone. The insert in the upper left indicates the location of the National Park in southeastern Germany. The study plot diagram illustrates the surveying method with main plot $\left(500 \mathrm{~m}^{2}\right)$ and subplots $\left(1 \mathrm{~m}^{2}, 50 \mathrm{~m}^{2}, 150 \mathrm{~m}^{2}\right)$.

Abb. 2.1 Karte des Nationalparks Berchtesgaden mit räumlicher Verbreitung des Borkenkäferbefalls und der Lage der 96 Probeflächen außerhalb des Maßnahmenbereichs Borkenkäferbekämpfung. Die kleine Karte gibt die Lage des Nationalparks an der südöstlichen Grenze Deutschlands an. Die Graphik des Probeflächendesigns verdeutlicht die Aufnahmemethodik mit Gesamtprobefläche $\left(500 \mathrm{~m}^{2}\right)$ und verschieden großen Teilflächen $\left(1 \mathrm{~m}^{2}, 50 \mathrm{~m}^{2}, 150 \mathrm{~m}^{2}\right)$.

The total forested area of the National Park is around 8,000 ha (40\%) (Konnert and Siegrist 2000). Approximately 6,000 ha of this forest is situated outside the bark beetle and forest management zone and in this area no manipulation of natural forest dynamics has taken place since 1978. This is in stark contrast to similar managed forests of the region which following bark beetle outbreaks, are subject to heavy salvage logging and when necessary, artificial regeneration measures. Following the winter storms in 1990, around 100 ha of spruce stands in the park were affected by bark beetle (primarily I. typographus). This led to nearly $100 \%$ mortality in patches of up to 1 ha in size. Dead 
trees were removed only within the bark beetle control zone of 1,900 ha along the border of the National Park in order to protect neighboring private forests from infestation (Fig. 2.1). The outbreak ceased naturally at the end of the 1990s (Nationalpark Berchtesgaden 2001). Unlike to the preceding events, the winter storms Kyrill in 2007 and Emma in 2008 caused disturbance primarily in the unmanaged zone. They initiated the infestation of approximately 400 ha of spruce forest and areas of heavily infected forest remain to date (Winter et al. 2015).

\section{Study design}

This study comprises of a GIS-based study analyzing the spatial distribution of bark beetle infestation and a field study. For the field study we designated and sampled three different stages of forest succession (Fig. 2.2) representing a chronosequence of forest development in unmanaged forests following spruce bark beetle outbreak. The three stages are described in detail by Winter et al. 2015 and are defined as: undisturbed spruce stands with an age of approximately 80-250 years and potential susceptibility to bark beetle infestation (mature stage), stands affected by bark beetle within the last five years (initial early-seral stage) and stands infested in the 1990s (advanced earlyseral stage). The early-seral stands sampled had experienced high severity outbreaks leading to 90 $100 \%$ mortality of overstorey spruce. Each stage was repeated six times on both north and south facing slopes in three altitudinal zones (montane: 700-1,200 m a.s.l., high montane: 1,200-1,400 m a.s.l. and subalpine: $>1,400 \mathrm{~m}$ a.s.l.), with the exception of the advanced early-seral stage which could not be surveyed in the subalpine zone. In total 96 plots ( 2 stages (mature and initial early-seral) x 3 zones $\times 2$ aspects $\times 6$ replications +1 stage (advanced early-seral) $\times 2$ zones $\times 2$ aspects $\times 6$ replications) were sampled.

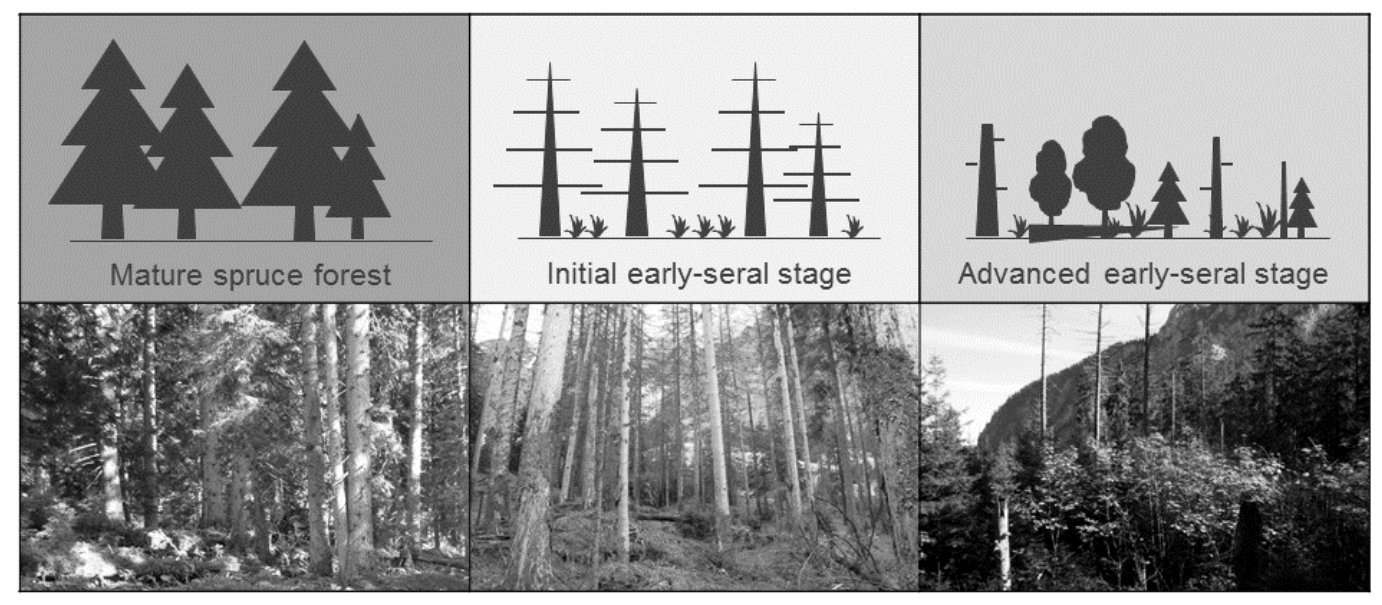

Fig. 2.2 Chronosequence of forest succession before and after bark beetle induced spruce dieback in the Berchtesgaden National Park.

Abb. 2.2 Unechte Zeitreihe der Waldentwicklung vor und nach Absterben des Fichtenbestandes durch Borkenkäferbefall im Nationalpark Berchtesgaden. 
The 1990s bark beetle gaps rarely exceeded one hectare in size and therefore only gaps with dimensions of 0.1-1.0 ha were chosen for comparison for the stand-scale study. Plots were selected based on aerial photographs from 1990, 1997, 2009 and 2012, and their status further verified in the field. Circular study plots of 0.05 ha in size were located in the center of bark beetle gaps for the initial and advanced early-seral sites. Study plots for mature spruce stands were located using the National Park forest inventory grid (Konnert and Siegrist 2000), with the criteria of being spruce dominated and as close as possible to the selected bark beetle gaps. The study plots were distributed over the entire spruce-dominated area of the National Park (Fig 2.1).

\section{Data collection}

To assess the spatial distribution of the bark beetle gaps in the National Park, all gaps excluding those in the bark beetle management zone were digitized in a GIS-based study and measured using aerial photographs from 1997 and 2012. For the stand scale study, gap age was reconstructed using aerial photographs from the years 1990, 1997, 2009 and 2012. The elevation of each study plot center was extracted from a digital elevation model (DEM) with an error of $<1 \mathrm{~m}$. Aspect and inclination of the plot were measured in the field. Data sampling in the field took place during the vegetation periods 2012 and 2013. Stand structural attributes were measured following a standard forest measurement protocol (Konnert and Siegrist 2000) and included tree bole location, diameter at breast height, and tree height measurements of all trees taller than two meters in height (hereafter referred to as "trees") on the 0.05 ha study plots (Winter et al. 2015). Existing allometric equations for the region were used to calculate living and dead wood volume (Kennel 1973). Distance to the nearest seed tree was estimated for the main tree species on each study plot up to a distance of $200 \mathrm{~m}$.

The relative amount of direct radiation compared to open field conditions (direct site factor - DSF) was estimated using hemispherical photography. In each plot eight $1 \mathrm{~m}^{2}$ fixed position subplots were created and one picture taken on each during overcast sky conditions with a lens height of one meter above ground. The pictures were analyzed using the WinSCANOPY software (Regent Instruments Inc. 2003). The threshold grey scale values separating sky, forest, or slope pixels were defined via calibrated segmentation (Wagner 1998; 2001).

For recording climate attributes, temperature loggers (HOBO U23 Pro v2) were installed in 32 plots (in each two of the six replications per plot category). They were mounted with one sensor in a radiation shield one meter above ground and one sensor five $\mathrm{cm}$ below ground and logged air and soil temperature every 30 minutes from June 2012 to October 2014. Days with a difference between minimal and maximal soil temperature of less than $0.2{ }^{\circ} \mathrm{C}$ were defined as days with snow cover on the ground. This corresponded very well (Pearson Correlation Coefficient R: 0.92) with the optical 
determination of snow days with the soil temperature time series. Type and thickness of humus layer and soil were assessed beside each $1 \mathrm{~m}^{2}$ subplot. Within these subplots, mean height of the herb layer was measured and the ground cover was assessed in $5 \%$ classes distinguishing among the following categories: rock, gravel, mineral soil, humus, litter, bark, moss layer, herb layer, dead wood, living wood and branches.

Within each main $500 \mathrm{~m}^{2}$ plot, tree regeneration was measured on one of three different subplot sizes in dependence upon its height. Seedlings and saplings up to $20 \mathrm{~cm}$ height (hereafter referred to as "small regeneration") were recorded on the eight $1 \mathrm{~m}^{2}$ subplots, saplings between 20 and $50 \mathrm{~cm}$ height (hereafter referred to as "medium regeneration") were recorded on a $50 \mathrm{~m}^{2}$ subplot, and saplings between 50 and $200 \mathrm{~cm}$ height (hereafter referred to as "large regeneration") were recorded on a $150 \mathrm{~m}^{2}$ subplot (see Fig. 2.1). For each of the regeneration individuals within the three subplot categories further variables were recorded: height, annual height increment of the last five years, diameter at root collar, vitality, visible biotic (including browsing) or abiotic damages, and the substrate on which they were found (e.g., dead wood, litter, herb layer). The age of the regeneration was determined by counting the shoot internodes. In older saplings, and where shoot damages have resulted from terminal browsing this method can lead to imprecise estimates. However more destructive alternatives were not feasible due to the long-term monitoring intention of this study. It has been demonstrated that this method can give rise to an imprecision in tree age estimation of up to 5 years (Batllori and Gutiérrez 2008). In addition, all vascular plants were mapped and assigned cover-abundance scores on the $500 \mathrm{~m}^{2}$ plots following the method of Braun-Blanquet (1964).

Seed availability over time was derived from data concerning fructification of the main tree species. For the Austrian part of the Northern Limestone Alps data was available from the Austrian Research Centre for Forests (BFW) (Litschauer 2014) and this conformed to the time series for Germany of Konnert et al. (2014).

\section{Statistical analysis}

To assess horizontal stand structure, the aggregation index R of Clark and Evans (1954) was calculated for the spatial distribution of live trees ( $>2 \mathrm{~m}$ tree height) within each plot. The Cumulative Distribution Function method (Baddeley et al. 2014) was used to correct for edge effects. Values of $R>1$ indicate a regular/dispersed distribution relative to a wholly random one, while values of $R<1$ suggest a clustered pattern. Species compositions were calculated for each height class of regeneration and for mature trees as shares of the stem numbers.

The assumption of independence between the three successional stages, the elevation zones and each of the response variables was assessed by means of resampling-based multiple testing (Westfall 
and Young 1993). In this procedure the $p$-values obtained are adjusted for multiple comparisons utilizing a step-down max-T approach (Algorithm 2.8 in Westfall and Young 1993). For each response variable, a post-hoc test (Tukey all-pair comparisons) was applied additionally in order to assess the differences of the rank transformed response variables between each pair of categories.

To assess whether a regeneration individual germinated before or after an episode of bark beetle induced spruce dieback, the age of each individual was linked to the year of the disturbance event at each specific site. In this study, all regeneration individuals and trees that were present before the relevant disturbance event are referred to as advance regeneration.

To compare the tree species composition between advanced early-seral stage plots, samples were ordered by dissimilarity using the Non-metric Multidimensional Scaling (NMDS) technique (Legendre and Legendre 1998). The species abundance matrix differentiates the six most common tree species (Picea abies, Larix decidua, Acer pseudoplatanus L., Fagus sylvatica, Fraxinus excelsior L. and Sorbus aucuparia L.) and four height classes $(0-20 \mathrm{~cm}, 20-50 \mathrm{~cm}, 50-200 \mathrm{~cm},>200 \mathrm{~cm})$. Abundances of tree species per height class were log-transformed prior to ordination in order to approach a normal distribution. The NMDS based on rank orders, was calculated with Bray-Curtis distances (Legendre and Legendre 1998), ordering species and sites in a two-dimensional scale. Additionally, the unconstrained ordination graph was overlaid with environmental variables to quantify their impact to the tree species composition. For this purpose, aspect was transformed from the units of degrees to ecologically more meaningful values ranging from 0 (south-south-west) to 2 (north-north-east) following the method of Beers et al. (1966). Ground cover percentage values were transformed using arc-sinus square-root transformation (Sokal and Rohlf 1995) before analysis in order to decrease variations in the center span while emphasizing changes close to the limit (0 or 100).

Browsing is a key threat for regeneration and can interfere significantly with the disturbance-driven processes (Ammer 1996a; Prietzel 2010). In order to include browsing pressure as an independent environmental variable in the analysis, we integrated regeneration data from the second (1995-1997) and third (2010-2012) National Park forest inventories (for method see Konnert and Siegrist 2000). This data included information on the percentage of browsed individuals per inventory plot and inventory period. Using this, a mean browsing percentage was calculated for each study plot by averaging the values of all inventory plots within a 10 ha radius of a plot (around 10 inventory plots). Each plot was subsequently assigned to one of the following 5 browsing classes: 1: $0 \%, 2: 0-5 \%, 3: 5-$ $15 \%, 4: 15-50 \%, 5: 50-100 \%$ of tree seedlings/saplings browsed. However, the share of the lesser browsed Norway spruce within the regeneration during the second inventory in the 1990s was much higher than during the third inventory period (most likely due to higher ungulate densities hindering successful regeneration of other species), feigning lower browsing pressure for that period. Taking 
only the browsing values of Norway spruce into account did not allow a spatial differentiation of browsing pressure due to the generally low percentages of Norway spruce seedlings browsed. Excluding Norway spruce seedlings obstructed information for the high montane and subalpine zones, where Norway spruce is the dominant species. Due to these limitations, browsing pressure could only be effectively included in the analyses for the current period (forest inventory III: 20102012).

To explore relationships among all explanatory variables a correlation matrix was calculated using non-parametric Spearman rank correlation coefficients. Variables that were highly correlated with each other $(r>0.6)$ were eliminated from further analysis to avoid multicollinearity. The remaining environmental variables were fitted onto the NMDS ordination with maximum correlation to the NMDS pattern. A permutation test (100,000 repetitions) was carried out to test the hypothesis of a relationship among the environmental variables and the tree species composition (Oksanen et al. 2012).

All statistical calculations and the creation of figures $2.3-2.7$ took place in the statistical framework R 3.1.0 using the add-on packages "multcomp" (for general parametric modeling, Hothorn et al. 2013), "spatstat" (for spatial point pattern analysis, Baddeley et al. 2014), "vegan" (for community ecology analyses, Oksanen et al. 2012), and "coin" (for permutation tests, Hothorn et al. 2014). The level of significance for all statistical inferences was defined with $\alpha \leq 0.05$.

\section{Results}

\section{Site conditions}

The mean bark beetle induced gap size in the unmanaged part of the National Park derived from the aerial photographs in the GIS-based study was 0.07 ha (twofold standard error: \pm 0.01 ha) on the 1997 image and 0.29 ha ( \pm 0.04 ha) on the 2012 image. $99 \%$ of the gaps (equals $85 \%$ gap area) were smaller than 0.5 ha in the 1990 infestation period, while $86 \%$ of the gaps (equals $38 \%$ of gap area) were smaller than 0.5 ha on the 2012 image (Fig. 2.3). In total, bark beetle infestation caused the mortality of around 30 ha of forest between 1990 and 1997, and 260 ha between 2007 and 2012 excluding the bark beetle management zone. The assignment of an exact year of infestation to individual gaps was not possible due to a lack of aerial photographs for the years between 1990-1997 and 2007-2012. Gaps were scattered and distributed over almost the entire spruce-dominated forest area (see Fig. 2.1).

On the stand scale, most condition metrics changed significantly with bark beetle induced spruce dieback, but stayed at similar levels over the first 25 years of succession following dieback 
(Table 2.1). Crown cover, solar radiation, live tree volume and height of ground vegetation differed significantly between the mature stand and the two early-successional stages at all elevations. Plots affected by bark beetle had lower crown cover and stand volume than the mature plots, significantly higher direct radiation at the forest floor, and increased ground vegetation height. At all elevations litter cover tended to be lower in early-seral stages than in mature stands, but only the high montane zone showed significant differences. Microclimatic conditions did not show any significant differences among the three successional stages. By trend, the post-disturbance stages revealed a longer duration of snow cover and a higher fluctuation of daily air temperature during the vegetation period. There were no significant differences in humus depth (Table 2.1) or proportions of humus types among the three successional stages.

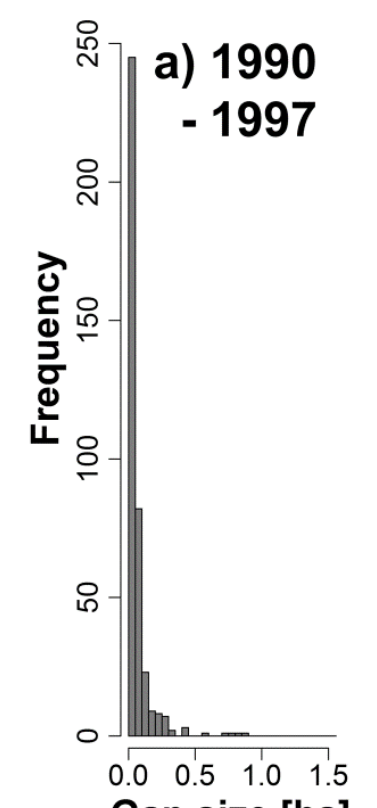

Gap size [ha]

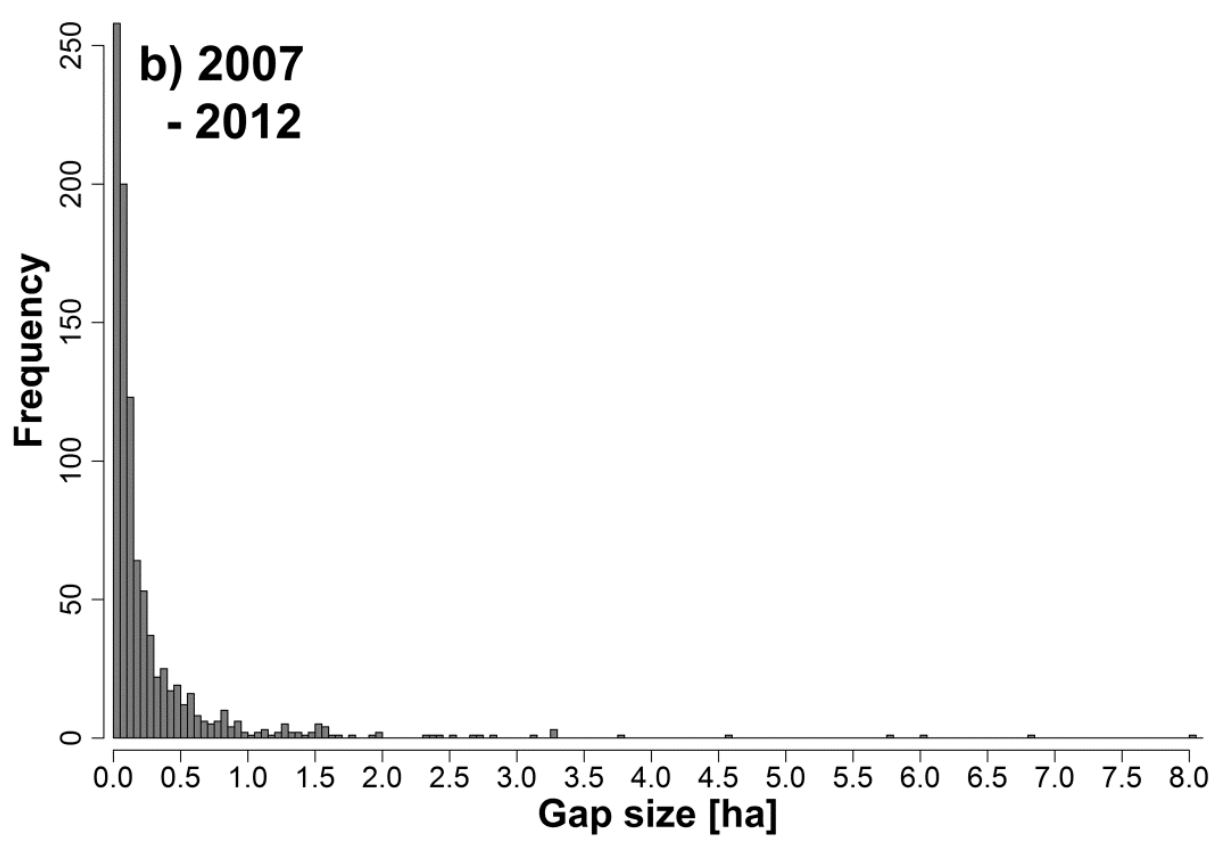

Fig. 2.3 Size frequency distribution of bark beetle gaps outside the bark beetle management zone of the Berchtesgaden National Park originating a) from 1990 to 1997 b) from 2007 to 2012.

Abb. 2.3 Häufigkeitsverteilung der Flächenausdehnung des Borkenkäferbefalls außerhalb des Maßnahmenbereichs Borkenkäferbekämpfung in den Zeiträumen von a) 1990 bis 1997 b) 2007 bis 2012. 


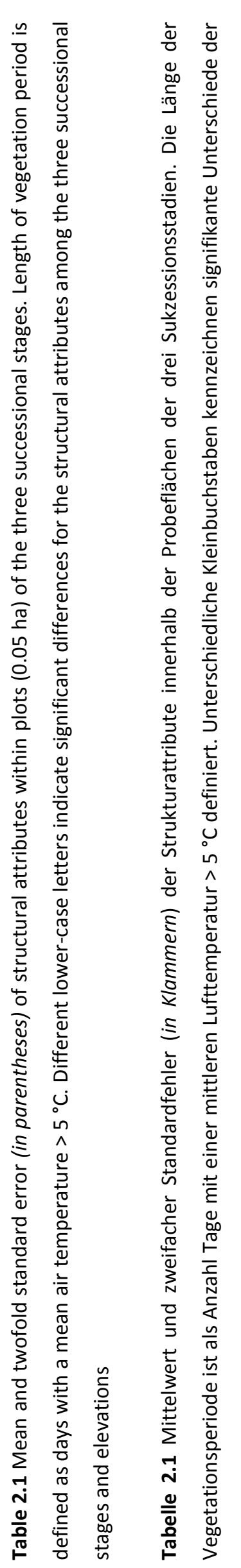

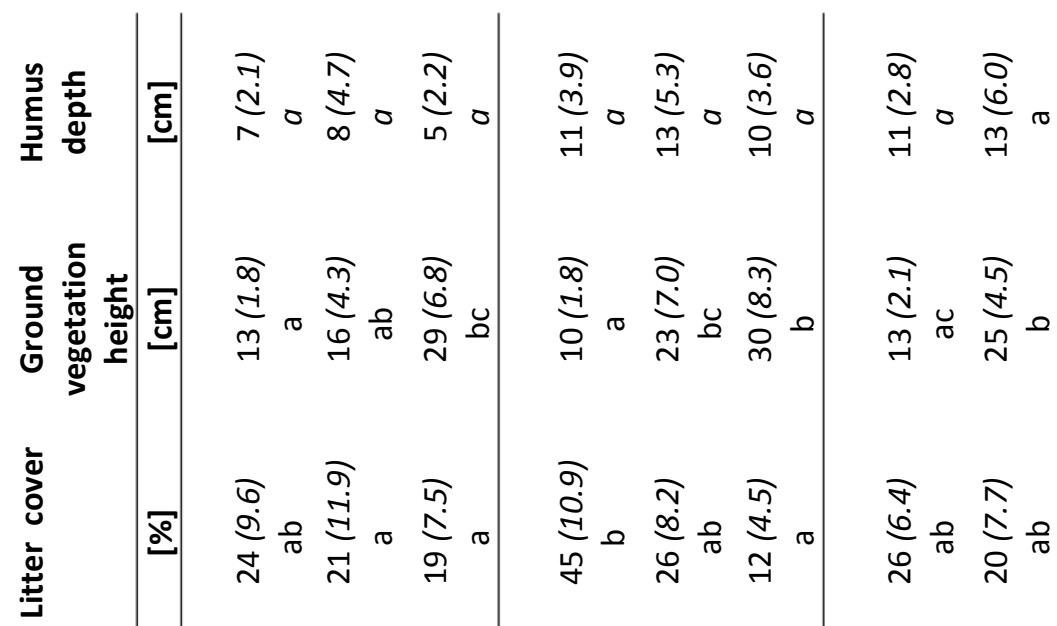

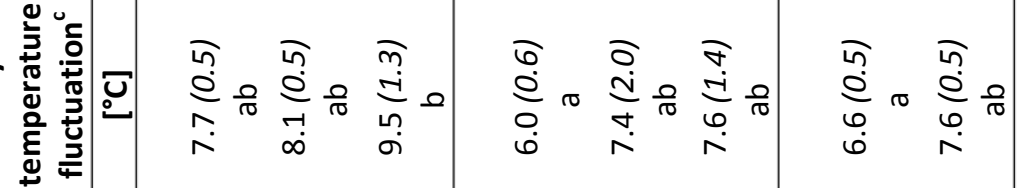

商

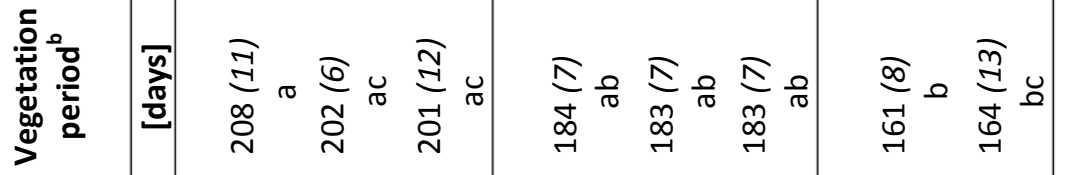

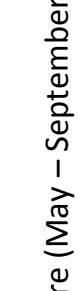

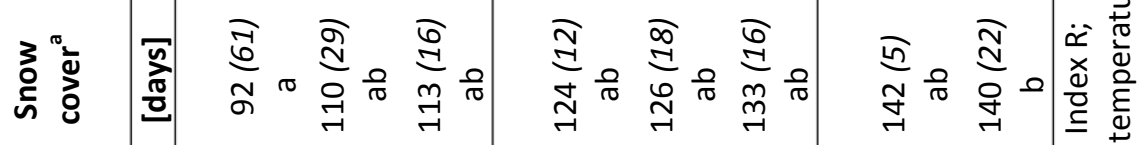

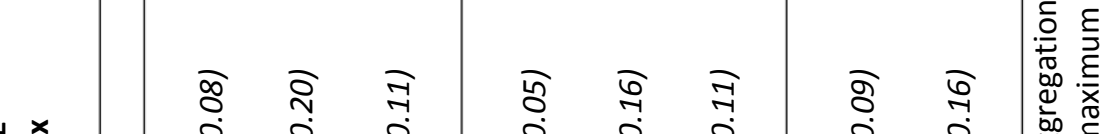

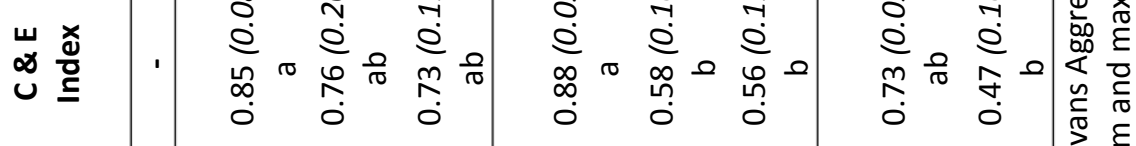

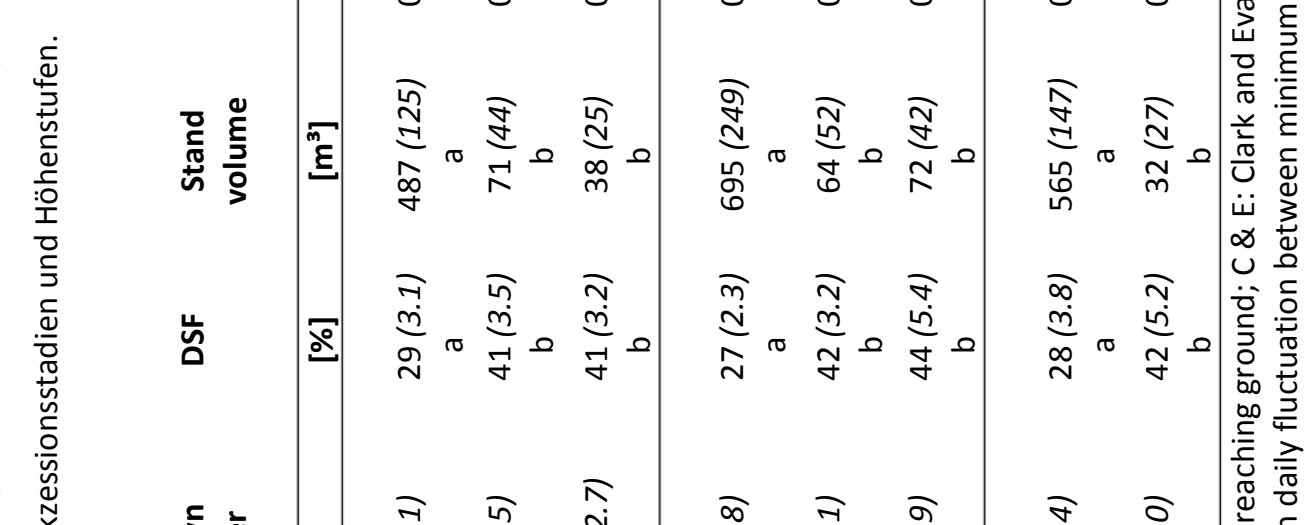

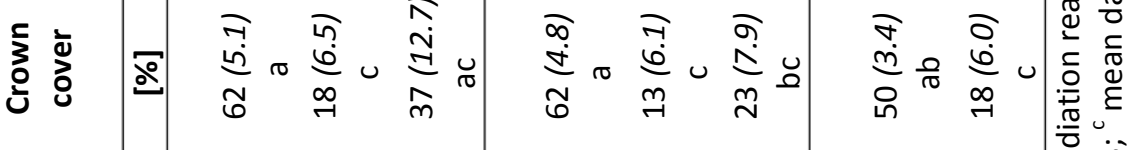

这 
For spruce, more than $90 \%$ of the nearest seed trees were found within $50 \mathrm{~m}$ of the center of the infested study plots at all elevations (Table 2.2). In contrast, seed trees of silver fir were further than $200 \mathrm{~m}$ from the plot in around $50 \%$ of the subalpine and montane plots and in $75 \%$ of the high montane plots. The frequency of closer seed trees increased slightly with elevation for European larch, but decreased with elevation for European beech, European ash and sycamore maple. For rowan, no seed tree was detected within a radius of $200 \mathrm{~m}$ for about $40 \%$ of all plots (Table 2.2).

Table 2.2 Distance of nearest seed trees to infested study plots (initial early-seral and advanced early seral stage) separating five distance classes and seven main tree species. Values give the percentage [\%] of study plots with seed trees within the given distance class

Tabelle 2.2 Entfernung der nächsten Samenbäume der sieben Hauptbaumarten zu den störungsbeeinflussten Probeflächen der beginnenden und fortschreitenden Sukzession (eingeteilt in fünf Entfernungsklassen). Die Tabellenwerte entsprechen dem Anteil [\%] der Probeflächen mit Samenbäumen innerhalb der entsprechenden Entfernungsklasse.

\begin{tabular}{rccccccc} 
& $\begin{array}{c}\text { Picea } \\
\text { abies }\end{array}$ & $\begin{array}{c}\text { Abies } \\
\text { alba }\end{array}$ & $\begin{array}{c}\text { Larix } \\
\text { decidua }\end{array}$ & $\begin{array}{c}\text { Acer } \\
\text { pseudopl. }\end{array}$ & $\begin{array}{c}\text { Sorbus } \\
\text { auc. }\end{array}$ & $\begin{array}{c}\text { Fagus } \\
\text { sylvatica }\end{array}$ & $\begin{array}{c}\text { Fraxinus } \\
\text { excelsior }\end{array}$ \\
\hline Montane & & & & & & & \\
within plot & $42 \%$ & $4 \%$ & $25 \%$ & $33 \%$ & $25 \%$ & $4 \%$ & $0 \%$ \\
$12.6-50 \mathrm{~m}$ & $50 \%$ & $13 \%$ & $29 \%$ & $21 \%$ & $38 \%$ & $4 \%$ & $13 \%$ \\
$50-100 \mathrm{~m}$ & $8 \%$ & $13 \%$ & $17 \%$ & $0 \%$ & $13 \%$ & $4 \%$ & $4 \%$ \\
$100-200 \mathrm{~m}$ & $0 \%$ & $17 \%$ & $13 \%$ & $29 \%$ & $4 \%$ & $4 \%$ & $13 \%$ \\
$>200 \mathrm{~m}$ & $0 \%$ & $54 \%$ & $17 \%$ & $17 \%$ & $21 \%$ & $83 \%$ & $71 \%$ \\
\hline High montane & & & & & & & \\
within plot & $50 \%$ & $8 \%$ & $33 \%$ & $0 \%$ & $13 \%$ & $0 \%$ & $0 \%$ \\
$12.6-50 \mathrm{~m}$ & $42 \%$ & $4 \%$ & $33 \%$ & $25 \%$ & $13 \%$ & $8 \%$ & $0 \%$ \\
$50-100 \mathrm{~m}$ & $8 \%$ & $4 \%$ & $21 \%$ & $13 \%$ & $17 \%$ & $0 \%$ & $0 \%$ \\
$100-200 \mathrm{~m}$ & $0 \%$ & $8 \%$ & $8 \%$ & $8 \%$ & $4 \%$ & $4 \%$ & $0 \%$ \\
$>200 \mathrm{~m}$ & $0 \%$ & $75 \%$ & $4 \%$ & $54 \%$ & $54 \%$ & $88 \%$ & $100 \%$ \\
\hline Subalpine & & & & & & & \\
within plot & $50 \%$ & $8 \%$ & $25 \%$ & $0 \%$ & $0 \%$ & $0 \%$ & $0 \%$ \\
$12.6-50 \mathrm{~m}$ & $42 \%$ & $33 \%$ & $17 \%$ & $17 \%$ & $25 \%$ & $8 \%$ & $0 \%$ \\
$50-100 \mathrm{~m}$ & $8 \%$ & $17 \%$ & $25 \%$ & $0 \%$ & $17 \%$ & $0 \%$ & $0 \%$ \\
$100-200 \mathrm{~m}$ & $0 \%$ & $0 \%$ & $25 \%$ & $17 \%$ & $8 \%$ & $0 \%$ & $0 \%$ \\
$>200 \mathrm{~m}$ & $0 \%$ & $42 \%$ & $8 \%$ & $67 \%$ & $50 \%$ & $92 \%$ & $100 \%$ \\
\hline
\end{tabular}

\section{Germination microsites}

While the majority of small regeneration $(<20 \mathrm{~cm})$ in the mature stage plots was found on litter covered microsites ( $70 \%$ ), the importance of moss and dead wood as growing substrate increased in the initial early-seral and advanced early-seral stages (Fig. 2.4). Ground covered with rock or herbs always showed lower regeneration densities than would be expected with equal spatial distribution of regeneration individuals (Fig. 2.4). 
Larger saplings may actively affect the substrate they grow in, such as through increased litter production. However, more than $95 \%$ of the medium and large regeneration in each of the successional stages did not grow on special substrates such as dead wood or root plates but on litter or in the moss or herb layers (data not shown).

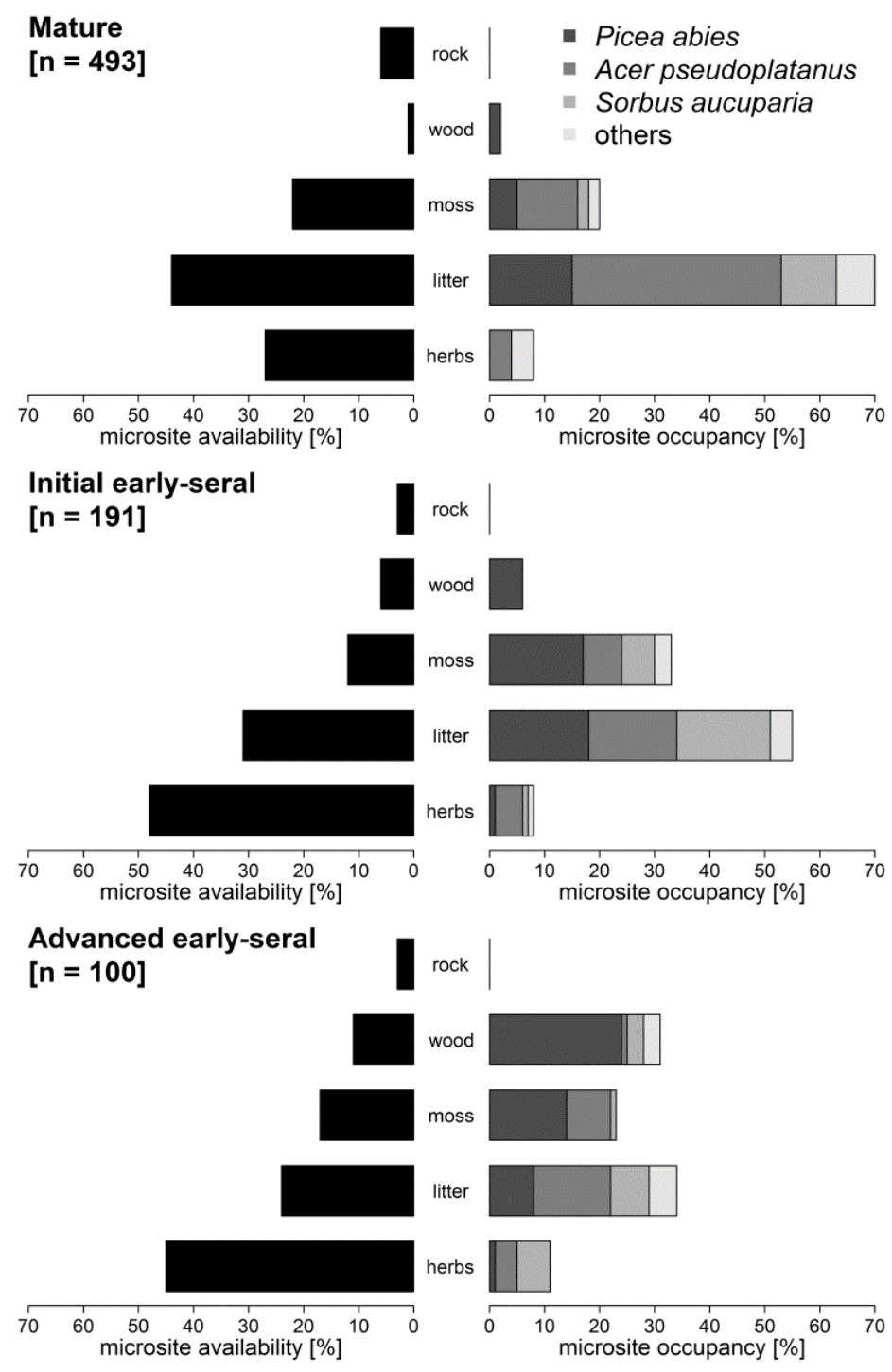

Fig. 2.4 Frequency of microsite availability (relative ground cover) and microsite occupancy for seedlings and saplings (0-20 cm tree height). [ $\mathrm{n}=$ ] gives the number of regeneration individuals included in the analyses. The "others" category includes regeneration individuals of Larix decidua, Abies alba, Fagus sylvatica, Fraxinus excelsior, Sorbus aria and Ulmus glabra. The advanced early-seral stage includes the montane and high montane, but not the subalpine elevations.

Abb. 2.4 Relative Verfügbarkeit bestimmter Mikrostandorte und deren Nutzung als Keimstandort von Keimlingen und Anwuchs (0-20 cm Baumhöhe). [ $\mathrm{n}=$ ] bezeichnet die Anzahl der in die Auswertung integrierten Jungwuchsindividuen. Die Kategorie „others“ beinhaltet Jungwuchsindividuen von Larix decidua, Abies alba, Fagus sylvatica, Fraxinus excelsior, Sorbus aria und Ulmus glabra. Die fortschreitende Sukzession beinhaltet die montane und hochmontane Höhenstufe, nicht aber die subalpine Höhenstufe. 


\section{Regeneration density and increment}

Regeneration densities were highly heterogeneous among plots, even those of the same successional stage (Fig. 2.5, Table 2.3). Thus, densities of small and medium regeneration were not significantly different among the three successional stages but were generally on a high level with medium densities of up to 10,000 individuals per hectare on the montane plots. Large regeneration was found significantly more frequently in plots in the advanced early-seral stage and showed densities of around 5,000 individuals/ha in the montane zone and 1,000 individuals/ha in the high montane zone, both approximately 20 years after the disturbance event (Fig. 2.5).

Table 2.3 Mean regeneration density [n/ha], twofold standard error (in parentheses) and share [\%] of the species of large regeneration individuals present in the three successional stages, separated for the altitudinal zones. The "Others" column includes regeneration individuals of Sorbus aria, Ulmus glabra, Tilia cordata, Betula spp. and Salix spp.

Tabelle 2.3 Mittlere Jungwuchsdichten [n/ha], zweifacher Standardfehler (in Klammern) und Baumartenanteile [\%] des großen Aufwuchses (50-200 cm Baumhöhe) innerhalb der Sukzessionsstadien und Höhenstufen. Die Spalte „Others" bezieht sich auf Anwuchs der Arten Sorbus aria, Ulmus glabra, Tilia cordata, Betula spp. und Salix spp.

\begin{tabular}{|c|c|c|c|c|c|c|c|c|c|}
\hline & $\begin{array}{l}\text { Picea } \\
\text { abies }\end{array}$ & $\begin{array}{c}\text { Abies } \\
\text { alba }\end{array}$ & $\begin{array}{c}\text { Larix } \\
\text { decidua }\end{array}$ & $\begin{array}{c}\text { Acer } \\
\text { pseudopl. }\end{array}$ & $\begin{array}{c}\text { Sorbus } \\
\text { auc. }\end{array}$ & $\begin{array}{c}\text { Fagus } \\
\text { sylvatica }\end{array}$ & $\begin{array}{l}\text { Fraxinus } \\
\text { excelsior }\end{array}$ & Others & $\begin{array}{c}\text { All } \\
\text { species }\end{array}$ \\
\hline \multicolumn{10}{|l|}{ Montane } \\
\hline \multirow[t]{2}{*}{ Mature } & $317(488)$ & $0(0)$ & $6(11)$ & $83(120)$ & $50(68)$ & $6(11)$ & $6(11)$ & $128(232)$ & 594(697) \\
\hline & $62 \%$ & $0 \%$ & $0 \%$ & $6 \%$ & $4 \%$ & $0 \%$ & $17 \%$ & $12 \%$ & $100 \%$ \\
\hline \multicolumn{10}{|l|}{ Initial } \\
\hline early-seral & $\begin{array}{c}334(273) \\
12 \%\end{array}$ & $0 \%$ & $0 \%$ & $\begin{array}{c}633(408) \\
45 \%\end{array}$ & $41 \%$ & $\begin{array}{l}34(27) \\
1 \%\end{array}$ & $0 \%$ & $\begin{array}{c}34(27) \\
1 \%\end{array}$ & $\begin{array}{c}1534(1034) \\
100 \%\end{array}$ \\
\hline early seral & $\begin{array}{c}2267(1172) \\
43 \%\end{array}$ & $\begin{array}{l}11(22) \\
0 \%\end{array}$ & $\begin{array}{c}161(311) \\
4 \%\end{array}$ & $\begin{array}{c}3150(2949) \\
32 \%\end{array}$ & $\begin{array}{c}617(514) \\
10 \%\end{array}$ & $\begin{array}{c}195(225) \\
5 \%\end{array}$ & $\begin{array}{c}317(449) \\
4 \%\end{array}$ & $\begin{array}{c}122(101) \\
2 \%\end{array}$ & $\begin{array}{c}6839(3619) \\
100 \%\end{array}$ \\
\hline \multicolumn{10}{|l|}{ High montane } \\
\hline \multirow[t]{2}{*}{ Mature } & $444(268)$ & $6(11)$ & $0(0)$ & $17(24)$ & $6(11)$ & $0(0)$ & $0(0)$ & $0(0)$ & 472(290) \\
\hline & $97 \%$ & $1 \%$ & $0 \%$ & $2 \%$ & $1 \%$ & $0 \%$ & $0 \%$ & $0 \%$ & $100 \%$ \\
\hline \multicolumn{10}{|l|}{ Initial } \\
\hline early-seral & $45 \%$ & $0 \%$ & $0 \%$ & $17 \%$ & $31 \%$ & $8 \%$ & $0 \%$ & $0 \%$ & $100 \%$ \\
\hline \multicolumn{10}{|l|}{ Advanced } \\
\hline early seral & $65 \%$ & $0 \%$ & $10 \%$ & $14 \%$ & $10 \%$ & $1 \%$ & $0 \%$ & $0 \%$ & $100 \%$ \\
\hline \multicolumn{10}{|l|}{ Subalpine } \\
\hline \multirow[t]{2}{*}{ Mature } & $450(263)$ & $94(189)$ & $0(0)$ & $89(125)$ & $44(68)$ & $0(0)$ & $0(0)$ & $0(0)$ & 678(390) \\
\hline & $80 \%$ & $6 \%$ & $0 \%$ & $12 \%$ & $3 \%$ & $0 \%$ & $0 \%$ & $0 \%$ & $100 \%$ \\
\hline \multicolumn{10}{|l|}{ Initial } \\
\hline \multirow[t]{2}{*}{ early-seral } & $450(413)$ & $0(0)$ & $6(11)$ & $650(1.228)$ & $200(252)$ & $0(0)$ & $0(0)$ & $11(15)$ & 1317(1516) \\
\hline & $67 \%$ & $0 \%$ & $1 \%$ & $24 \%$ & $8 \%$ & $0 \%$ & $0 \%$ & $1 \%$ & $100 \%$ \\
\hline
\end{tabular}



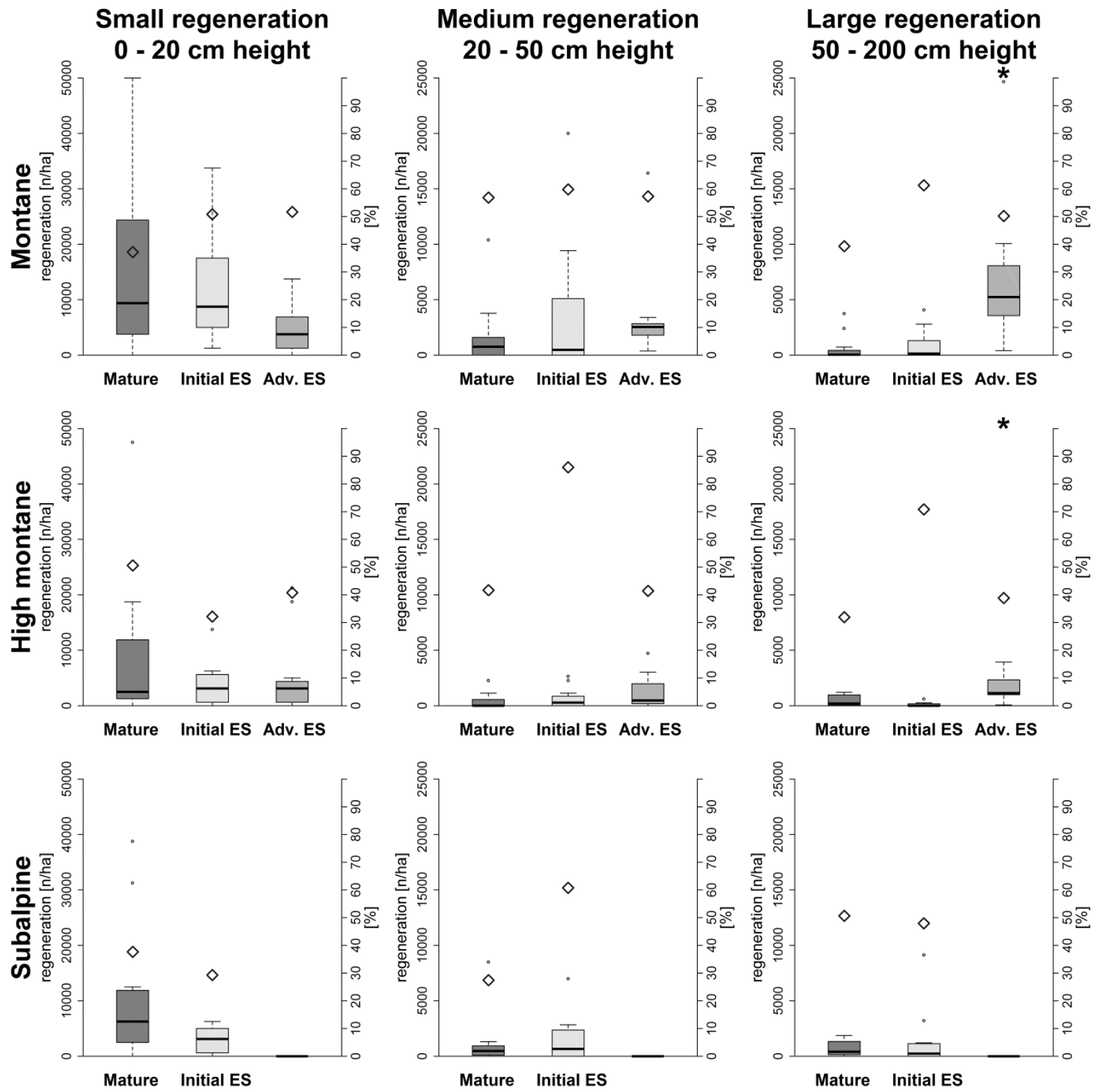

Fig. 2.5 Regeneration densities [n/ha] (boxplots) and mean ratio [\%] of regeneration individuals with terminal browsing (rhombi) in the three successional stages (Initial ES: Initial early-seral, Adv. ES: Advanced early-seral) by altitudinal zone and regeneration size. Stars indicate significant differences in regeneration density among the successional stages. There are no significant differences in browsing intensity among the three successional stages.

Abb. 2.5 Jungwuchsdichten [n/ha] (Boxplot) und mittlerer Anteil [\%] an Jungwuchsindividuen mit Terminaltriebverbiss (Raute) in den drei Sukzessionsstadien (Mature: Fichtenaltbestand; Initial ES: Beginnende Sukzession; Adv. ES: fortschreitende Sukzession) differenziert nach Höhenstufen und JungwuchsHöhenklassen. Die Sterne markieren signifikante Unterschiede an Jungwuchsdichten zwischen den Sukzessionsstadien. Es bestehen keine signifikanten Unterschiede im mittleren Anteil des Jungwuchses mit Terminaltriebverbiss zwischen den Sukzessionsstadien. 
Approximately $50 \%$ of all regeneration sampled had a damaged terminal shoot due to ungulate browsing (Fig. 2.5). There were no significant differences in mean browsing intensity among the three successional stages.

The mean annual height increment of large Norway spruce regeneration was significantly higher on the advanced early-seral stage plots compared to the mature plots in all years (2008-2012) and at all elevations. In most cases Norway spruce regeneration in the initial early-seral stage was not significantly different in mean annual height increment compared to those in the mature stage. The mean annual height increment of large sycamore maple regeneration at montane elevations was higher in both post-disturbance stages than in the mature stage during the past five years while in the high montane elevation it was higher only in years 2010 and 2012. Large rowan regeneration showed significantly higher increments on the early-seral plots in some years, but did not reveal a clear pattern. The height increment of all tree species was significantly correlated with the amount of direct radiation at the forest floor (data not shown).

\section{Species composition and stand structure}

Norway spruce, sycamore maple and rowan held the highest shares of the large regeneration (Table 2.3) with densities [n/ha] of all species decreasing with increased elevation. Due to the high between-plot variability, the only significant differences in species share were found in the high montane zone. Here there was a lower proportion of Norway spruce and a higher proportion of European larch in the advanced early-seral stage than in the mature stage. Also notable in the montane zone was that silver fir and European beech accounted for less than $1 \%$ and less than $5 \%$ respectively of the regeneration found in the advanced early-seral stage (Table 2.3). In the tree layer at montane and high montane elevations, Norway spruce had a significantly lower mean share in the initial early-seral stage (66\%) and advanced early-seral stage (56\%), than in the mature stage ( $88 \%$ ). In contrast, European ash and rowan slightly increased their proportions along the chronosequence. Sycamore maple had a higher share in the initial early-seral stage (7\%) and advanced early-seral stage (15\%) than in the mature stage (3\%), but due to a large variation this can only be shown by trend $(p=0.15)$.

The NMDS based on rank abundances showed a differentiated pattern of tree species composition among the surveyed sites of the advanced early-seral plots. The non-metric fit of $R^{2}=0.95$, the linear fit of $R^{2}=0.72$ and the stress of 0.22 show a good fit of the ordination procedure in the twodimensional scale. The sites were ordered to a large extent along two gradients as shown in Figures $2.6 \mathrm{a}$ and $2.6 \mathrm{~b}$ : the first of these reaches from the high montane north facing plots to the montane south facing plots and constitutes a thermal gradient (upper left to lower right in Fig 2.6 a). The 
second reaches from plots with low regeneration densities to those with very high regeneration densities and constitutes a regeneration density gradient (lower left to upper right in Fig 2.6 b). As shown in Figure $2.6 \mathrm{c}$, in both the regeneration and the tree layer Larix was associated with high montane plots, whereas Fraxinus and Fagus were associated with south-facing plots of lower elevations. Acer and Sorbus were most closely linked to those plots with high regeneration densities, and Picea fell in the center and did not reveal a clear alignment with either of the two gradients. In Figure $2.6 \mathrm{~d}$ the relationship of regeneration densities to overlaid environmental variables of each species is described by the angle and direction of arrows, while the degree of correlation is represented by the arrow length. The distance to the nearest seed trees of Larix was correlated with thermal gradient and was negatively linked to elevation and grass cover. The mean height of ground vegetation and the distance to the nearest Acer seed trees fell in the opposite direction on the regeneration density gradient. The browsing intensity parameter did not show enough of a correlation with the ordination to be included as an explaining environmental variable on the diagram.

All three successional stages exhibited horizontal clustering of trees within the plot (Clark and Evans value of $R<1$ ). However, clustering was significantly more evident in the post-disturbance stages compared to the mature forests, at least in the high montane zone (Table 2.1).

\section{Germination period}

The ratio of regeneration individuals that germinated in advance of a disturbance event to those that germinated post-disturbance was significantly lower in the advanced early-seral stage than in the initial early-seral stage (data not shown). In the high montane plots of the advanced early-seral stage about $88 \%$ of the large regeneration germinated after the spruce dieback. In the montane zone this figure was close to $100 \%$ for those individuals measured in 2012/13 (Fig. 2.7). The single older trees in both zones were either Norway spruce of the former secondary tree layer, mature sycamore maple trees or regeneration individuals that germinated shortly before the spruce dieback. At montane elevations, regeneration germination rates increased steadily following the disturbance event with the majority of individuals originating between 2003 and 2006 (7 to 11 years postdisturbance). In contrast, the high montane elevations showed a much more pronounced pulse in germination rate between 2007 and 2009 (12 to 14 years post-disturbance) (Fig. 2.7). The share of Norway spruce in the regeneration increased, by trend, over time.

The mean percentage of regeneration individuals germinating prior to 1993 (before the first infestations) was not significantly different among successional stages. Even in plots of the mature 
stage, which were unaffected by the bark beetle infestations, more than $80 \%$ of the regeneration individuals measured in 2012/13 germinated after 1993 (data not shown).
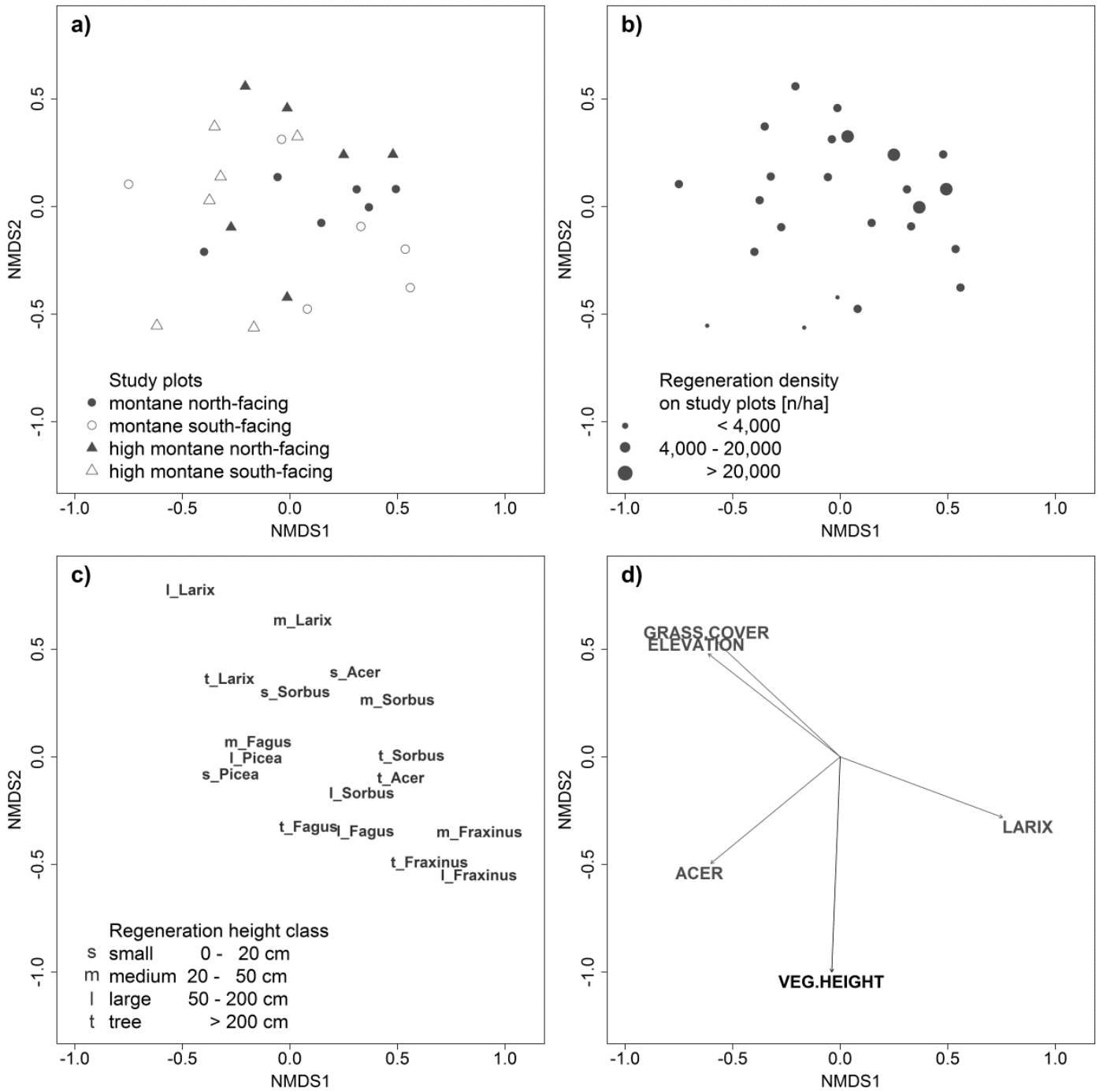

Fig. 2.6 NMDS ordination diagram of study plots (symbols; a \& b), tree regeneration (lower case; separating height classes and tree species; c) and environmental variables (upper case; d). The species names in upper case (e.g., LARIX) represent the distance of the nearest seed trees of the species to the study plots. The environmental variable printed in black corresponds significantly to the unconstrained $\operatorname{NMDS}(p<0.05)$, those printed in grey represent only trends $(p=0.10)$.

Abb. 2.6 NMDS Ordination der Probeflächen (Symbole; a \& b), des Jungwuchses (Kleinbuchstaben; unterschieden nach Höhenklassen und Baumarten; c) und relevanter Umweltparameter (Großbuchstaben; d). Die in Großbuchstaben dargestellten Gattungsnamen (z.B. LARIX) bilden die Entfernung des nächsten potentiellen Samenbaums dieser Art zur Probefläche ab. Der in schwarz dargestellte Umweltparameter korreliert signifikant mit der NMDS Ordination $(p<0,05)$, die in grau dargestellten Umweltparameter korrelieren nur mit einem Signifikanzwert von $p=0,10$. 

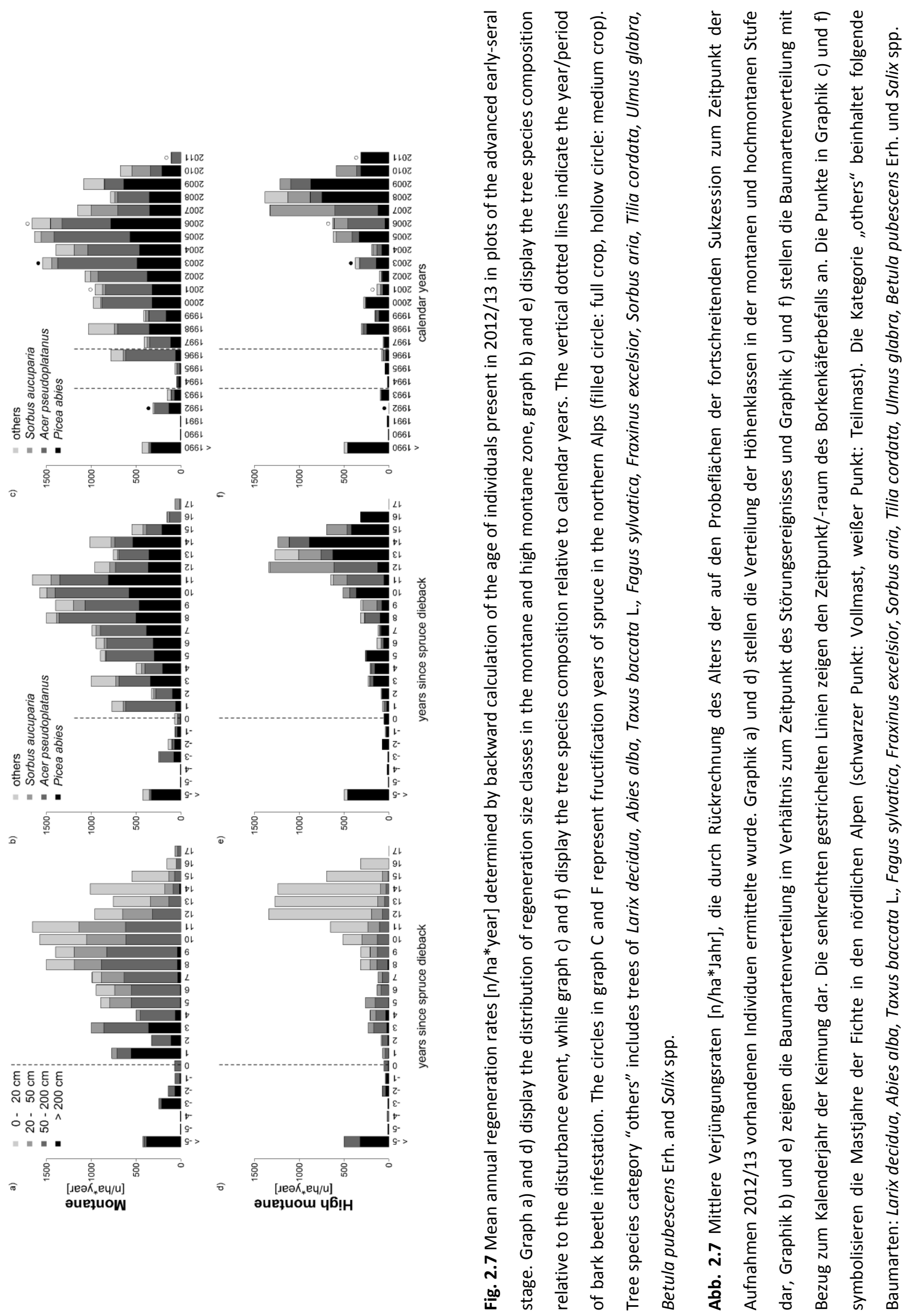


\section{Discussion}

Our study explored natural regeneration processes in a bark beetle disturbance-driven ecosystem. The findings demonstrate a clear alteration of environmental conditions and forest structures following severe bark beetle outbreaks, namely in reduced cover of living trees, increased light availability, and increased cover and height of ground vegetation. Although regeneration densities were heterogeneous among the study plots, the majority of plots were already relatively densely stocked twenty years after the dieback of the initial mature Norway spruce stands. Regeneration was clustered and dominated by sycamore maple and Norway spruce (Table 2.1 and 2.3, Fig. 2.7). Most notably, the proportion of the advance regeneration was negligible with the vast majority of seedlings germinating after the disturbance event. The findings suggest that in their capacity for regeneration, the studied mountain forests maintain a high degree of resilience in spite of bark beetle outbreaks. It may well be that this form of disturbance generates an acceleration in the transition from pure Norway spruce forests towards a more natural species composition. However, Norway spruce remains the dominant species and this will continue to be the case for the next generation at least. In the following section we discuss in detail the post-disturbance regeneration processes at different elevations.

\section{Site conditions affecting natural regeneration}

Our hypothesis that seedlings germinating after a disturbance event will be restricted to so called "safe sites" - specific microsites often at elevated or protracted positions on root plates or dead wood - was only partially reflected in our results. We found that the importance of dead wood as a growing substrate increased from the mature stage to the advanced early-seral stage for spruce regeneration (Fig. 2.4), especially in the high montane zone. Generally though, the vast majority of regeneration mapped 20 years after the spruce dieback did not grow on special substrates. Instead it was found on litter, or in the moss or herb layer. This is in accordance with results from highelevation forests in British Columbia (Brang et al. 2003) where conifer regeneration on rotten wood exhibited higher germination densities but lower survival rates compared to ground seedbeds. Contrary to this results however, many studies in Central Europe underline the exceptional importance of dead wood for the regeneration process of Norway spruce in low and high mountain ranges (Jehl 2001; Meyer and Petersen 2003; Jonášová and Prach 2004; Kupferschmid and Bugmann 2005; Baier et al. 2007; Keidel et al. 2008). Norway spruce deadwood in our study was 17 to 25 years old and consisted not only of downed logs but also a considerable number of snags. It is well known that in boreal forests standing snags take much longer to decompose than downed logs (Storaunet and Rolstad 2002). Moreover, it may take several decades for a dead Norway spruce to fall and the time between fall and complete decomposition of a log is around 100 years (Storaunet and Rolstad 
2002). It has also been shown that the degree of decomposition of Norway spruce wood best for conifer regeneration is reached 30-60 years following the death of a tree (Zielonka 2006). Therefore it seems likely that in our study area the importance of deadwood as a regeneration substrate will increase over the next decades, especially at higher elevations where bark beetle induced gaps are yet to be closed.

Mean height of ground vegetation, extent of grass cover, elevation, and distance to potential seed trees were all identified as main drivers of tree species composition and abundance (Fig. 2.6 a-d). Twenty years after the spruce dieback, the lowest regeneration densities were found at high elevations and in plots with grass dominated ground cover or distinct vegetation layers. This is in accordance with other literature (Baier et al. 2007). Higher elevations are characterized by longer snow cover, shorter vegetation periods (Table 2.1), generally harsher climates, and frequently by worse soil conditions. This leads to challenging conditions for both regeneration and tree growth (Körner 2007; Ellenberg and Leuschner 2010). Successful regeneration is further impeded by dense herb and grass layers which restrain the warm-up of the soil, cover seedlings under the litter layer during winter time, and compete for water, light and nutrients (Ott et al. 1991, Ammer 1996b; Brang 1996; Fischer 1998; Wohlgemuth et al. 2002). This is reflected in our data on germination substrates where herb covered ground always exhibited lower regeneration densities than would be expected with equal spatial distribution of regeneration (Fig. 2.4).

For Norway spruce, seed availability was not identified as an influential environmental variable effecting regeneration abundance in our study. This is highly plausible because $90 \%$ of all infested study plots had a distance to the nearest seed tree of under $50 \mathrm{~m}$ (Table 2.2) and mean dispersal distance of spruce seeds is frequently cited as 30-50 m (e.g., Kutter and Gratzer 2006; Cremer et al. 2012). For larch and maple the impact of seed source distance is more significant. However, at least for larch, where the vector of Larix is directly opposite that of elevation (Figs. $2.6 \mathrm{c}$ and $2.6 \mathrm{~d}$ ), this result may only reflect the fact that larch naturally occurs more frequently in higher elevations (Ellenberg and Leuscher 2010). The low correlation of the browsing intensity parameter with tree species ordination is expected to be a result of an inappropriate method rather than representing the real situation. Although our ordination method does not express it for all species, the limited seed availability together with high ungulate densities is expected to be the main restriction to successful regeneration of European beech, sycamore maple, European ash and silver fir in the montane zone (Gill and Beardall 2001, Kutter and Gratzer 2006, Wagner et al. 2010).

We found a significant increase in annual height increment for Norway spruce, sycamore maple and rowan in the early-seral stages compared to the mature stage. This can be largely attributed to the increase in direct radiation available to the regeneration layer and the resultant enhanced growing 
conditions for seedlings and saplings (Ammer 1996b; Senn and Schönenberger 2001; Diaci et al. 2005).

\section{Development towards natural stand structures}

The main natural forest type at middle elevations of the Northern Limestone Alps is mixed-montane European beech forest with Norway spruce and silver fir and this is also true of the study region (Köstler and Mayer 1974; Walentowski et al. 2006). In the past, high timber demand from the salt mining industry resulted in the loss of natural species composition and promoted pure Norway spruce stands throughout accessible areas (Knott et al. 1988; Konnert and Siegrist 2000). During the last 20 years, bark beetle induced spruce dieback has initiated a return towards mixed mountain forests. In accordance with our hypotheses significantly reduced proportions of Norway spruce were found in both regeneration and tree layers (Table 2.3). However, the proportions of the rather light demanding sycamore maple and rowan are expected to decrease during further succession (Hein et al. 2009; Höllerl and Mosandl 2009). The key species of the natural forest cover - European beech and silver fir - were largely missing. As stated above, we expect this to be due to a lack of seed trees in most stands and in the case of silver fir, compounded by high ungulate densities (Ammer 1996a; Motta 1996; Prietzel and Ammer 2008; Klopcic et al. 2010). It therefore appears that the natural remigration of European beech and silver fir into the stands in increasing proportions will take centuries rather than decades (Küßner 1997; Diaci 2002). Nevertheless the increasing proportion of deciduous trees - sycamore maple, rowan, European beech and European ash - may have already begun to influence stand climate, soil organic layer and habitat conditions. A preceding analysis (Winter et al. 2015) found an increase in species density of the herb and shrub layer and many additional faunistic species groups due to changed forest structures, increased dead wood, and light availability. It may be that the increased proportion of deciduous species has also enhanced this.

Our study clearly supported the hypothesis of increased horizontal structural heterogeneity within the stand following bark beetle outbreak, indicated by the significantly clustered Clark and Evans Aggregation Index in the early-seral stage plots. This spatial pattern is typically attributed to natural old-growth forests (Bauhus et al. 2009). However, there are limitations to the designation of oldgrowth structures because the distinctly different age structures of mature and early-seral stands makes comparison of long-term structural attributes difficult (Spies and Franklin 1991; Zenner 2000).

The disturbance regime in the Berchtesgaden National Park is driven by a combination of smallerscale storm damage and bark beetle outbreak and results in a mosaic of standing and lying deadwood areas of different generations and sizes surrounded by undisturbed forest. This creates a forested landscape of exceptionally high structural heterogeneity. The pattern of bark beetle 
disturbance is scattered and small-scale when compared to that found in other managed and unmanaged forest areas in Central Europe (e.g., Meyer and Petersen 2003; Lausch et al. 2011) and North America (e.g., Meddens at al. 2012; Meddens and Hicke 2014) (Figs. 2.1 \& 2.3). The reasons behind these differences in spatial dispersion and dynamics are still largely unknown. One factor for the apparent resistance to large-scale dispersion of bark beetle in the Berchtesgaden Alps may be the high topographic heterogeneity of the area. Whatever the case, this spatial heterogeneity is recognized as having the potential to significantly improve wildlife habitat and future regulation of natural hazards, insects and pathogens (Turner at al. 2013).

\section{Resilience capacity}

Two decades after the bark beetle induced spruce dieback the majority of the montane study plots were already densely stocked with a new tree layer, while at high montane elevations there was only a patchy layer of regeneration (Table 2.3 and Fig. 2.5). Both levels of regeneration density are within the range of what is known from other unmanaged mountain forests in Central Europe following windthrow or bark beetle disturbance (Bauer 2002; Wohlgemuth et al. 2002; Meyer and Petersen 2003; Keidel et al. 2008; Jonášová and Prach 2004; Heurich et al. 2012). As discussed above it is expected that regeneration density will further increase as the decay stage of the fallen stems approaches the optimum for spruce germination (Zielonka 2006). The regeneration densities found support our hypothesis that altered site conditions following the bark beetle induced spruce dieback do not hinder natural regeneration processes.

Contrary to our expectations and the results of other studies (e.g., Bauer 2002; Rammig et al. 2006; El Kateb et al. 2009; Wild et al. 2014), the vast majority of the regeneration measured in 2012/2013 on the plots of the advanced early-seral stage was not composed of advance regeneration, but instead had germinated after the disturbance event (Fig. 2.7). It is possible that the method of age determination by counting shoot internodes may have caused imprecision in tree age estimation of up to 5 years (Batllori and Gutiérrez 2008). However, this does not undermine the finding that the majority of the present regeneration cohorts were established after the disturbance event.

We found high densities of small and medium regeneration even in mature stands (Fig. 2.5). If this situation accurately represents the conditions of the infested stands prior to the bark beetle attack a question arises over the fate of the pre-disturbance seedlings met on these plots. However, we interpret this to show that the conditions for successful establishment of tree seedlings under the canopy of the mature stand twenty years ago were much worse than today due to considerably higher browsing damages. Due to the chronosequence method applied here, losses of seedlings over time could not be detected. However, it is worth noting that the regeneration densities of plots 
unaffected by disturbance increased from the second (1995-1997) to the third (2010-2012) National Park forest inventory (unpublished data). Thus we find it likely that enhanced growing conditions have been created by a change in hunting policy and the resulting decrease in ungulate densities. The peaks in germination rates (Fig. 2.7) might also indicate this change. The results support the wellestablished idea that forest ecosystems are highly resilient following disturbances providing browsing does not prohibit the establishment of new seedlings (Heinze et al. 2011; Pellerin et al. 2010). In our study this appears to be true both with and without the presence of advance regeneration. Globally, high browsing levels are found to simplify forest composition and structure and this in turn may cause reduced resilience to emerging stressors associated with climate change (White 2012). In addition, forests affected in this way are less able to provide ecosystem services such as carbon storage, biological diversity and forest products (Martin et al. 2011; White 2012).

\section{Management implications}

European beech and silver fir are currently missing in the non-natural pure spruce stands. The natural remigration of these species is likely to take several tree generations even though they would naturally characterize the majority of the mixed mountain forests. Conversion of these forests to a more natural species composition may become a key management target in part due to the increased recognition of climate change related threats. Forest managers will then need to implement active reintroduction measures in order to establish European beech and silver fir more quickly. In order for this to succeed any strategy must include the appropriate control of ungulate densities.

Most of the bark beetle gaps studied were already quite densely stocked two decades after the dieback of the mature stand. However, in comparison to planting, the natural regeneration process may partly delay establishment and canopy closure. This is particularly the case on high montane sites where germination depends heavily on the presence of deadwood substrate in an advanced state of decay (e.g., Zielonka 2006). The protracted and light dominated early-seral stages have been proven integral to the survival of the full range of organisms and functions associated with canopyopening disturbances (Müller et al. 2008, Lehnert et al. 2013, Winter et al. 2015). Therefore, forest management could increase structural heterogeneity and enhance biodiversity through a reduction or delay in replanting of disturbed or logged forest sites.

As demonstrated in this study and many previous studies (e.g., Kupferschmid Albisetti et al. 2003; Jonášová and Prach 2004; Baier et al. 2007), the importance of retaining deadwood to support natural regeneration - as nutrient supply, growing substrate and barrier against snow movements increases with altitude. Leaving snag stands unharvested in Norway spruce mountain forests is likely 
to result in effective protection against rock fall and avalanche release for approximately 30 years (Kupferschmid Albisetti et al. 2003). Additionally, a high volume of dead wood enhances biodiversity of saproxylic species (Winter et al. 2015). The high regeneration ability following disturbance is proof of the high resilience of mountain forests. With controlled ungulate densities ensuring that regeneration persists, bark beetle infestations increase structural diversity of the studied mountain forests on both stand and landscape scales. Alongside a natural species composition, this structural diversity is a key part of ensuring resistance against natural disturbances on both scales. For the above reasons, we find that where possible integrating rather than eliminating the evolving forest gaps, deadwood and diversified environmental conditions left following bark beetle outbreak is a viable management option in the Northern Limestone Alps.

\section{Acknowledgements}

We are grateful to the numerous forest students who supported the inventory of stand and regeneration attributes in the field in 2012 and 2013. We also thank the Bavarian State Ministry for the Environment and Public Health (StMUG), for funding the research project "Forest dynamics following spruce bark beetle calamities in the National Park Berchtesgaden". The origin of funding had no effect on the outcomes of this research. Finally, we thank Rob Coventry for very helpful linguistic corrections and two anonymous reviewers for valuable comments on a previous version of this manuscript.

\section{References}

Ammer C (1996a) Impact of ungulates on structure and dynamics of natural regeneration of mixed mountain forests in the Bavarian Alps. For Ecol Manag 88 (1-2): 43-53. doi: 10.1016/S0378-1127(96)03808-X

Ammer C (1996b) Konkurrenz um Licht. Zur Entwicklung der Naturverjüngung im Bergmischwald. Forstliche Forschungsberichte München 158: 1-198

Ammer C (1998) Die Fichte in der natürlichen Verjüngung des Bergmischwaldes. AFZ-Der Wald 8: 396-399

Ammer C, Vor T, Knoke T, Wagner S (2010) Der Wald-Wild-Konflikt. Analyse und Lösungsansätze vor dem Hintergrund rechtlicher, ökologischer und ökonomischer Zusammenhänge. Göttinger Forstwissenschaften 5: 1184

Ammer C, Balandier P, Bentsen NS, Coll L, Löf M (2011) Forest vegetation management under debate: an introduction. Eur J Forest Res 130: 1-5. doi: 10.1007/s10342-010-0452-6

Attiwill PM (1994) The disturbance of forest ecosystems: the ecological basis for conservative management. For Ecol Manag 63: 247-300. doi: 10.1016/0378-1127(94)90114-7

Baddeley A, Turer R, Rubak E (2014) Pakage "spatstat" Spatial Point Pattern analysis, model-fitting, simulation, tests. Online: http://cran.r-project.org 
Baier R, Meyer J, Göttlein A (2007) Regeneration niches of Norway spruce (Picea abies [L.] Karst.) saplings in small canopy gaps in mixed mountain forests of the Bavarian Limestone Alps. Eur J Forest Res 126 (1): 11-22. doi: $10.1007 /$ s10342-005-0091-5

Batllori E, Gutiérrez E (2008) Regional tree line dynamics in response to global change in the Pyrenees. J Ecology 96: 1275-1288. doi: 10.1111/j.1365-2745.2008.01429.x

Bauer ML (2002) Walddynamik nach Borkenkäferbefall in den Hochlagen des Bayerischen Waldes. Dissertation, Technische Universität München

Bauhus J, Puettmann KJ, Messier C (2009) Silviculture for old-growth attributes. For Ecol Manag 258: 525-537. doi: 10.1016/j.foreco.2009.01.053

Beers T, Dress P, Wensel L (1966) Aspect transformation in site productivity research. J For Res 64: 691-692

Beniston M, Stephenson DB, Christensen OB, Ferro CA, Frei C, Goyette S et al. (2007) Future extreme events in European climate: an exploration of regional climate model projections. Climatic Change 81: 71-95. doi: $10.1007 /$ s10584-006-9226-z

Brang P (1996) Ansamungsgunst und Verteilung der Direktstrahlung in schlitzförmigen Bestandesöffnungen zwischenalpiner Fichtenwälder. Schweiz Z Forstwes 147 (10): 761-784

Brang P (2001) Resistance and elasticity: promising concepts for the management of protection forests in the European Alps. For Ecol Manag 145: 107-119. doi: 10.1016/S0378-1127(00)00578-8

Brang P, Moran J, Puttonen P, Vyse A (2003) Regeneration of Picea engelmannii and Abies lasiocarpa in highelevation forests of south-central British Columbia depends on nurse-logs. The Forestry Chronicle 79 (2): 273279

Braun-Blanquet J (1964) Pflanzensoziologie. 3rd edn. Springer, Wien, New York

Bruelheide H, Luginbühl U (2009) Peeking at Ecosystem Stability: Making Use of a Natural Disturbance Experiment to Analyze Resistance and Resilience. Ecology 90 (5): 1314-1325. doi: 10.1890/07-2148.1

Clark PJ, Evans FC (1954) Distance to Nearest Neighbor as a Measure of Spatial Relationships in Populations. Ecology 35 (4): 445-453. doi: 10.2307/1931034

Cremer E, Ziegenhagen B, Schulerowitz K, Mengel C, Donges K, Bialozyt R et al. (2012) Local seed dispersal in European silver fir (Abies alba Mill.): lessons learned from a seed trap experiment. Trees 26 (3): 987-996. doi: 10.1007/s00468-012-0676-9

Diaci, J (2002) Regeneration dynamics in a Norway spruce plantation on a silver fir-beech forest site in the Slovenian Alps. For Ecol Manage 161: 27-38 doi: 10.1016/S0378-1127(01)00492-3

Diaci J, Pisek R, Boncina A (2005) Regeneration in experimental gaps of subalpine Picea abies forest in the Slovenian Alps. Eur J Forest Res 124 (1): 29-36. doi: 10.1007/s10342-005-0057-7

Donato DC, Campbell JL, Franklin JF (2012) Multiple successional pathways and precocity in forest development: can some forests be born complex? J Veg Sci 23 (3): 576-584. doi: 10.1111/j.16541103.2011.01362.x

Dorren LK, Berger F, Imeson AC, Maier B, Rey F (2004) Integrity, stability and management of protection forests in the European Alps. For Ecol Manag 195 (1-2): 165-176. doi: 10.1016/j.foreco.2004.02.057 
El Kateb H, Schölch M, Mosandl R (2009) Waldbau-Verfahren für den Bergmischwald Empfehlungen für die Praxis auf wissenschaftlicher Grundlage. LWF aktuell 71: 9-11

Ellenberg H, Leuschner C (2010) Vegetation Mitteleuropas mit den Alpen. Ulmer, Stuttgart

Fischer A (1998) Verjüngung und Wiederbewaldung in den Hochlagen des Nationalparks Bayerischer Wald In: Bayerische Landesanstalt für Wald und Forstwirtschaft (1998): Borkenkäferproblematik im Nationalpark Bayerischer Wald. Ergebnisse des internationalen Expertengremiums. Nationalparkverwaltung Bayerischer Wald, Grafenau

Franklin JF, Spies TA, van Pelt R, Carey AB, Thornburgh DA, Berg DR et al. (2002) Disturbances and structural development of natural forest ecosystems with silvicultural implications, using Douglas-fir forests as an example. For Ecol Manag 155 (1-3): 399-423. doi: 10.1016/S0378-1127(01)00575-8

Frehner M, Wasser B, Schwitter R (2005) Nachhaltigkeit und Erfolgskontrolle im Schutzwald Wegleitung für Pflegemassnahmen in Wäldern mit Schutzfunktion. Bundesamt für Umwelt, Wald und Landschaft (BUWAL), Bern

Frich P, Alexander LV, Della-Marta P, Gleason B, Haylock M, Klein Tank A, Peterson T (2002) Observed coherent changes in climatic extremes during the second half of the twentieth century. Climate Research 19: 193-212. doi: 10.3354/cr019193

Gill RMA, Beardall V (2001) The impact of deer on woodlands: the effects of browsing and seed dispersal on vegetation structure and composition. Forestry 74: 209-218. doi:10.1093/forestry/74.3.209

Grimm V, Wissel C (1997) Babel, or the ecological stability discussions: an inventory and analysis of terminology and a guide for avoiding confusion. Oecologia 109: 323-334. doi: 10.1007/s004420050090

Hartl-Meier C, Dittmar C, Zang C, Rothe A (2014) Mountain forest growth response to climate change in the Northern Limestone Alps. Trees 28: 819-829. doi: 10.1007/s00468-014-0994-1

Hein S, Collet C, Ammer C, Le Goff N, Skovsgaard JP, Savill P (2009) A review of growth and stand dynamics of Acer pseudoplatanus L. in Europe: implications for Silviculture. Forestry 82 (4) 361-385. doi:10.1093/forestry/cpn043

Heinze E, Boch S, Fischer M, Hessenmöller D, Klenk B, Müller J et al. (2011) Habitat use of large ungulates in northeastern Germany in relation to forest management. For Ecol Manag 261: 288-296. doi: 10.1016/j.foreco.2010.10.022

Heurich M, Baierl F, Zeppenfeld T (2012) Waldentwicklung im Nationalpark Bayerischer Wald in den Jahren 2006 bis 2011. Ergebnisse der Luftbildauswertung und Hochlageninventur. Nationalparkverwaltung Bayerischer Wald. Berichte aus dem Nationalpark 8/12

Höllerl S (2009a) Auswirkungen von waldbaulichen Maßnahmen auf die Stabilität (Resistenz und Elastizität) von Fichtenreinbeständen in der Bergmischwaldstufe der Bayerischen Alpen. Forstliche Forschungsberichte München 207: 1-268

Höllerl S (2009b) Berücksichtigung finanzieller Aspekte bei waldbaulichen Entscheidungen - eine Fallstudie für reine Fichtenbestände in der Bergmischwaldzone. Forstarchiv 80: 4-14

Höllerl S, Mosandl R (2009) Der Bergahorn im Bergmischwald - unübertroffen in seinem Verjüngungspotential. LWF Wissen 62: 24-29 
Hothorn T, Bretz F, Westfal P, Heiberger RM, Schuetzenmeister A (2013). Package "multcomp" Simultaneous Inference in General Parametric Models. Online: http://cran.r-project.org

Hothorn T, Hornik K, van de Wiel, MA, Zeileis A (2014) Package "coin" Conditional Inference Procedures in a Permutation Test Framework. Online: http://cran.r-project.org

Jehl H (2001) Die Waldentwicklung nach Windwurf in den Hochlagen des Nationalparks Bayerischer Wald In: Nationalparkverwaltung Bayerischer Wald (2001): Waldentwicklung im Bergwald nach Windwurf und Borkenkäferbefall. Nationalparkverwaltung Bayerischer Wald. Wissenschaftliche Reihe 14

Jonášová M, Prach K (2004) Central-European mountain spruce (Picea abies (L.) Karst.) forests: regeneration of tree species after a bark beetle outbreak. Ecological Engineering 23 (1): 15-27. doi: 10.1016/j.ecoleng.2004.06.010

Kärvemo S, Rogell B, Schroeder M (2014) Dynamics of spruce bark beetle infestation spots: Importance of local population size and landscape characteristics after a storm disturbance. For Ecol Manag 334: 232-240. doi: 10.1016/j.foreco.2014.09.011

Keidel S, Meyer P, Bartsch N (2008) Regeneration eines naturnahen Fichtenwaldökosystems im Harz nach großflächiger Störung. Forstarchiv 79: 187-196

Kennel E (1973) Bayerische Waldinventur 1970/71 Inventurabschnitt 1: Großrauminventur Aufnahme- und Auswertungsverfahren. Forschungsberichte der Forstlichen Forschungsanstalt München 11

Klopcic M, Klemen J, Boncina A (2010) Long-term changes of structure and tree species composition in Dinaric uneven-aged forests: are red deer an important factor? Eur J Forest Res 129: 277-288. doi: 10.1007/s10342009-0325-z

Knott H, Bernhart A, Feulner M (1988) Geschichte der Salinenwälder von Berchtesgaden. Nationalpark Berchtesgaden. Forschungsbericht 12

Konnert V, Siegrist J (2000) Waldentwicklung im Nationalpark Berchtesgaden von 1983 bis 1997. Nationalpark Berchtesgaden. Forschungsbericht 43

Konnert M, Schneck D, Zollner A (2014) Blühen und Fruktifizieren unserer Waldbäume in den letzten 60 Jahren. LWF Wissen 74: 37-45

Körner C (2007) The use of 'altitude' in ecological research. Trends Ecol Evol 22 (11): 569-574. doi: 10.1016/j.tree.2007.09.006

Köstler J, Mayer H (1974) Gutachten über die künftige Behandlung des Waldes im Alpenpark Berchtesgadener Land. München

Kräuchi N, Brang P, Schönenberger W (2000) Forests of mountainous regions: gaps in knowledge and research needs. For Ecol Manag 132: 73-82. doi: 10.1016/S0378-1127(00)00382-0

Krehan H, Steyrer G (2006) Klimaänderung - Schadorganismen bedrohen unsere Wälder. BFWPraxisinformation (10): 15-17

Kupferschmid AD, Bugmann H (2005) Effect of microsites, logs and ungulate browsing on Picea abies regeneration in a mountain forest. For Ecol Manag 205 (1-3): 251-265. doi: 10.1016/j.foreco.2004.10.008 
Kupferschmid AD, Schönenberger W, Wasem U (2002) Tree regeneration in a Norway spruce snag stand after tree die-back caused by Ips typographus. For Snow Landsc Res 77 (1/2): 149-160

Kupferschmid Albisetti AD, Brang P, Schönenberger W, Bugmann H (2003) Decay of Picea abies snag stands on steep mountain slopes. The Forest Chronicle 79 (2): 247-252

Küßner R (1997) Secondary succession processes in spruce (Picea abies) stands of the eastern Erzgebirge possibilities for silvicultural control and their relevance for an ecologically based forest conversion. Forstwiss Cbl 116 (2): 359-369

Kutter M, Gratzer G (2006) Neue Methoden zur Abschätzung der Samenverbreitungsdistanzen von Waldbäumen am Beispiel der Verbreitung von Picea abies, Abies alba und Fagus sylvatica. Austrian Journal of Forest Science 123 (3): 103-120

Lausch A, Fahse L, Heurich M (2011) Factors affecting the spatio-temporal dispersion of Ips typographus (L.) in Bavarian Forest National Park: A long-term quantitative landscape-level analysis. For Ecol Manage 261: 233245. doi: 10.1016/j.foreco.2010.10.012

Legendre P, Legendre L (1998) Numerical ecology. 2nd English edn. Elsevier, Amsterdam

Lehnert LW, Bässler C, Brandl R, Burton PJ, Müller J (2013) Conservation value of forests attacked by bark beetles: Highest number of indicator species is found in early successional stages. J Nature Conserv 21 (2): 97104. doi: 10.1016/j.jnc.2012.11.003

Litschauer R (2014) Untersuchungen zur Samenproduktion österreichischer Waldbäume. BFW. Online: http://bfw.ac.at/020/2259.html. Assessed 20 October 2014

Martin TG, Arcese P, Scheerder N (2011) Browsing down our natural heritage: Deer impacts on vegetation structure and songbird populations across an island archipelago. Biological Conservation 144: 459-469. doi: 10.1016/j.biocon.2010.09.033

Meddens AJH, Hicke JA (2014) Spatial and temporal patterns of Landsat-based detection of tree mortality caused by a mountain pine beetle outbreak in Colorado, USA. For Ecol Manage 322: 78-88. doi: 10.1016/j.foreco.2014.02.037

Meddens AJH, Hicke JA, Ferguson CA (2012) Spatiotemporal patterns of observed bark beetle-caused tree mortality in British Columbia and the western United States. Ecological Applications 22 (7): 1876-1891

Meister G (1969) Überlegungen zur künftigen Betriebsgestaltung im oberbayerischen Hochgebirge. Forstwiss Centralbl 88: 202-230

Meyer P (2013) Wie schnell werden Wirtschaftswälder zu Urwäldern? AFZ-Der Wald 24: 11-13

Meyer P, Petersen R (2003) Regeneration naturnaher Fichtenwälder nach großflächigen Störungen - Beispiele aus dem Harz. Forst und Holz 58 (13/14): 401-406

Motta R (1996) Impact of wild ungulates on forest regeneration and tree composition of mountain forests in the Western Italian Alps. For Ecol Manag 88 (1-2): 93-98. doi: 10.1016/S0378-1127(96)03814-5

Müller J, Bußler H, Goßner M, Rettelbach T, Duelli P (2008) The European spruce bark beetle Ips typographus in a national park: from pest to keystone species. Biodivers Conser. 17 (12): 2979-3001. doi: 10.1007/s10531-0089409-1 
Nationalpark Berchtesgaden (2001) Nationalparkplan. Nationalpark Berchtesgaden

Oksanen J, Blanchet FG, Kindt R, Legendre P, Minchin PR, O'Hara RB et al. (2012) Package "vegan" Community Ecology Package. Online: http://cran.r-project.org

Ott E, Lüscher F, Frehner M, Brang P (1991) Verjüngungsökologische Besonderheiten im Gebirgsfichtenwald im Vergleich zur Bergwaldstufe. Schweiz Z Forstwes 142 (11): 879-904

Otto H-J (1994) Waldökologie. Ulmer, Stuttgart

Overbeck M, Schmidt M (2012) Modelling infestation risk of Norway spruce by Ips typographus (L.) in the Lower Saxon Harz Mountains (Germany). For Ecol Manag 266: 115-125. doi: 10.1016/j.foreco.2011.11.011

Papaik MJ, Canham CD (2006) Species resistance and community response to wind disturbance regimes in northern temperate forests. Journal of Ecology 94: 1011-1026. doi: 10.1111/j.1365-2745.2006.01153.x

Pechmann H von (1932) Beiträge zur Geschichte der Forstwirtschaft im oberbayerischen Hochgebirge. Forstwiss Centralb/ 54: 605-622, 645-661, 693-709, 721-734.

Pellerin M, Saïd S, Richard E, Hamann J-L, Dubois-Coli C, Hum P (2010) Impact of deer on temperate forest vegetation and woody debris as protection of forest regeneration against browsing. For Ecol Manag 260: 429437. doi: 10.1016/j.foreco.2010.04.031

Prietzel J (2010) Schutzwälder der Nördlichen Kalkalpen: Verjüngung, Mikroklima, Schneedecke und Schalenwild. Protection forests in the Northern Limestone Alps: stand regeneration, microclimate, snow cover and ungulates. Swiss Forestry Journal 161 (1): 12-22. doi: 10.3188/szf.2010.0012

Prietzel J, Ammer C (2008) Montane Bergmischwälder der Bayerischen Kalkalpen: Reduktion der Schalenwilddichte steigert nicht nur den Verjüngungserfolg, sondern auch die Bodenfruchtbarkeit. Allg Forst- $u$ J- Ztg 179 (5/6): 104-112

Puettmann KJ, Ammer C (2007) Trends in North American and European regeneration research under the ecosystem management paradigm. Eur J Forest Res 126 (1): 1-9. doi: 10.1007/s10342-005-0089-z

Rammig A, Fahse L, Bugmann H, Bebi P (2006) Forest regeneration after disturbance: A modelling study for the Swiss Alps. For Ecol Manag 222 (1-3): 123-136. doi: 10.1016/j.foreco.2005.10.042

Regent Instruments Inc (2003) WinScanopy 2003b for hemispherical image analysis. Québec. Online: http://www.regentinstruments.com

Roberts MR (2004) Response of the herbaceous layer to natural disturbance in North American forests. Can J Bot 82 (9): 1273-1283. doi: 10.1139/B04-091

Schelhaas M-J, Nabuurs G-J, Schuck A (2003) Natural disturbances in the European forests in the 19th and 20th centuries. Global Change Biology 9: 1620-1633. doi: 10.1046/j.1529-8817.2003.00684.x

Schönenberger W (2002) Post windthrow stand regeneration in Swiss mountain forests: the first ten years after the 1990 storm Vivian. For Snow Landsc Res 77 (1/2): 61-80

Seidl R, Schelhaas M-J, Lindner M, Lexer MJ (2009) Modeling bark beetle disturbances in a large scale forest scenario model to assess climate change impacts and evaluate adaptive management strategies. Reg Environ Change 9: 101-119. doi: 10.1007/s10113-008-0068-2 
Seidl R, Schelhaas M-J, Lexer MJ (2011) Unraveling the drivers of intensifying forest disturbance regimes in Europe. Global Change Biology 17 (9): 2842-2852. doi: 10.1111/j.1365-2486.2011.02452.x

Seidl R, Schelhaas M-J, Rammer W, Verkerk PJ (2014) Increasing forest disturbances in Europe and their impact on carbon storage. Nature Climate Change 4: 806-810. doi: 10.1038/NCLIMATE2318

Senn J, Schönenberger W (2001) Zwanzig Jahre Versuchsaufforstung Stillberg: Überleben und Wachstum einer subalpinen Aufforstung in Abhängigkeit vom Standort. Schweiz Z Forstwes 152 (6): 226-246

Sokal RM, Rohlf FJ (1995) Biometry. Freeman, New York

Spandau L (1988) Angewandte Ökosystemforschung im Nationalpark Berchtesgaden. Nationalpark Berchtesgaden. Forschungsbericht 20

Spies TA, Franklin JF (1991) The structure of natural young, mature, and old-growth Douglas-fir forests. In: Ruggiero LF, Aubry KB, Carey AB, Huff MH (Eds.) Wildlife and Vegetation of Unmanaged Douglas-fir Forests. USDA Forest Service General Technical Report PNW-GTR-285: 91-110

Storaunet KO, Rolstad J (2002) Time since death and fall of Norway spruce logs in lod-growth and selective cut boreal forest. Can J For Res 32: 1801-1812. doi: 10.1139/X02-105

Swanson ME, Franklin JF, Beschta RL, Crisafulli CM, DellaSalla DA, Hutto RL et al. (2011) The forgotten stage of forest succession: early successional ecosystems on forest sites. Front Ecol Environ 9: 117-125. doi: $10.1890 / 090157$

Turner MG, Donato DC, Romme WH (2013) Consequences of spatial heterogeneity for ecosystem services in changing forest landscapes: priorities for future research. Landscape Ecol 28: 1081-1097. doi: 10.1007/s10980012-9741-4

Wäldchen J, Schulze ED, Mund M, Winkler B (2011) Der Einfluss politischer, rechtlicher und wirtschaftlicher Rahmenbedingungen des 19. Jahrhunderts auf die Bewirtschaftung der Wälder im Hainich-Dün-Gebiet (Nordthüringen). Forstarchiv 82: 35-47 doi: 10.2376/0300-4112-82-35

Wagner S (1998) Calibration of grey values of hemispherical photographs for image analysis. Agric For Meteorol 90 (2): 103-117. doi: 10.1016/S0168-1923(97)00073-7

Wagner S (2001) Relative radiance measurements and zenith angle dependent segmentation in hemispherical photography. Agric For Meteorol 107: 103-115. doi: 10.1016/S0168-1923(00)00232-X

Wagner S, Collet C, Madsen P, Nakashizuka T, Nyland RD, Sagheb-Talebi K (2010) Beech regeneration research: From ecological to silvicultural aspects. For Ecol Manage 259: 2172-2182. doi:10.1016/j.foreco.2010.02.029

Walentowski H, Ewald J, Fischer A, Kölling C, Türk W (2006) Handbuch der natürlichen Waldgesellschaften Bayerns Ein auf geobotanischer Grundlage entwickelter Leitfaden für die Praxis in Forstwirtschaft und Naturschutz. 2nd edition. Geobotanica Verlag, Freising

Westfall P, Young S (1993) Resampling-based Multiple Testing. John Wiley \& Sons, New York

White MA (2012) Long-term effects of deer browsing: Composition, structure and productivity in a northeastern Minnesota old-growth forest. For Ecol Manag 269: 222-228. doi: 10.1016/j.foreco.2011.12.043 
Wild J, Kopecký M, Svoboda M, Zenáhlíková J, Edwards-Jonášová M, Herben T, Vandvik V (2014) Spatial patterns with memory: tree regeneration after stand-replacing disturbance in Picea abies mountain forests. $J$ Veg Sci 25 (6): 1327-1340. doi: 10.1111/jvs.12189

Winter M-B, Ammer C, Baier R, Donato DC, Seibold S, Müller J (2015) Multi-taxon alpha diversity following bark beetle disturbance: Evaluating multi-decade persistence of a diverse early-seral phase. For Ecol Manag 338: 3245. doi: 10.1016/j.foreco.2014.11.019

Wohlgemuth T, Kull P, Wüthrich H (2002) Disturbance of microsites and early tree regeneration after windthrow in Swiss mountain forests due to the winter storm Vivian 1990. For Snow Landsc Res 77 (1/2): 17-47

Zenner EK (2000) Do residual trees increase structural complexity in Pacific Northwest coniferous forests? Ecological Applications 10 (3): 800-810. doi: 10.2307/2641046

Zielonka T (2006) When does dead wood turn into a substrate for spruce replacement? J Veg Sci 17: 739-746. doi: 10.1111/j.1654-1103.2006.tb02497 


\section{Kapitel 3}

\section{Multi-taxon alpha diversity following severe bark beetle disturbance: Evaluating multi-decade persistence of a diverse early- seral phase}

Winter, M.-B., Ammer, C., Baier, R., Donato, D.C., Seibold, S., Müller, J. ${ }^{1}$

Forest Ecology and Management (2015) 338: 32-45.

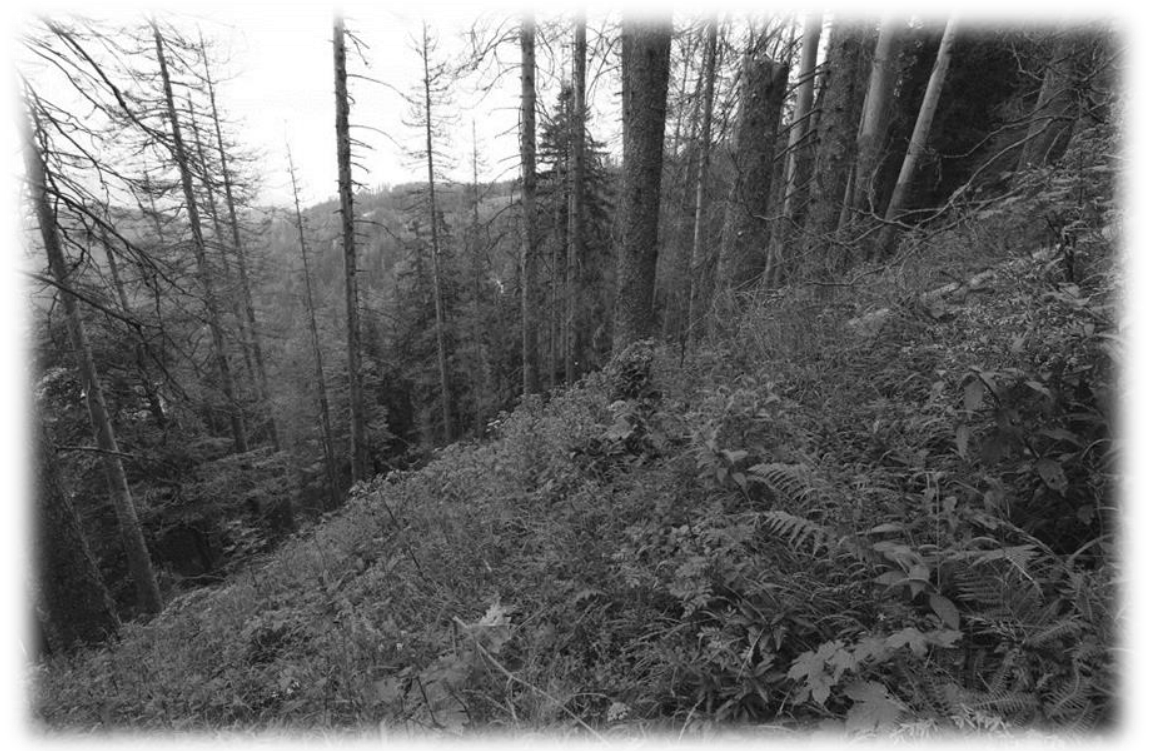

Stadium der beginnenden Sukzession mit blühendem Fuchsschem Greiskraut (Senecio ovatus) im Watzmannkar, zwei Jahre nach Borkenkäferbefall (Foto: H. Maltan).

1 Maria-Barbara Winter war für die Datenaufnahme, die Auswertung der Daten, die Aufbereitung der Ergebnisse und die Erstellung des Manuskripts verantwortlich. Christian Ammer, Roland Baier, Daniel Donato, Sebastian Seibold und Jörg Müller betreuten Datenauswertung und Manuskripterstellung.

Die Publikation ist hier um deutsche Übersetzungen des Titels und der Über- bzw. Unterschriften von Tabellen und Abbildungen erweitert. 


\title{
Multi-taxon alpha diversity following bark beetle disturbance: Evaluating multi-decade persistence of a diverse early-seral phase
}

\section{Alpha-Diversität nach Borkenkäferbefall: Langjähriges Andauern einer struktur- und artenreichen frühsukzessionalen Phase}

Maria-Barbara Winter ${ }^{\mathrm{a}, \mathrm{b}} *$, Christian Ammer ${ }^{\mathrm{b}}$, Roland Baier ${ }^{\mathrm{a}}$, Daniel C. Donato ${ }^{c}$, Sebastian Seibold ${ }^{\mathrm{d}, \mathrm{e}}$, Jörg Müller ${ }^{\text {d,e }}$

${ }^{a}$ Berchtesgaden National Park Administration, Doktorberg 6, 83471 Berchtesgaden, Germany. (Email: mbwinter@gmx.de, roland.baier@npv-bgd.bayern.de, Tel: +49 8652 9686131)

${ }^{\mathrm{b}}$ Department of Silviculture and Forest Ecology of the Temperate Zones, Georg-August-Universität Göttingen, Büsgenweg 1, 37077 Göttingen, Germany. (Email: christian.ammer@forst.unigoettingen.de)

${ }^{c}$ Washington State Department of Natural Resources, PO Box 47014, Olympia, WA, USA. (Email: daniel.donato@dnr.wa.gov)

d Bavarian Forest National Park Administration, Freyunger Straße 2, 94481 Grafenau, Germany. (Email: sebastian-seibold@gmx.de, joerg.mueller@npv-bw.bayern.de)

${ }^{\mathrm{e}}$ Terrestrial Ecology Research Group, Department of Ecology and Ecosystem Management, Center for Food and Life Sciences Weihenstephan, Technische Universität München, Hans-Carl-von-CarlowitzPlatz 2, 85354 Freising, Germany

* Corresponding author

\begin{abstract}
Early-successional forest ecosystems developing after natural disturbances, such as fire, windthrow or insect outbreaks, can support high diversity of habitat structures, species and processes. However, the specific structural and multi-taxon responses that best define a distinct early-seral pre-forest phase, and the longevity of that phase, remain important research questions. To address these questions, we assessed stand structural heterogeneity and species density of various taxa across three biological kingdoms in the initial early-seral period ( 3 years after severe bark beetle outbreak), advanced early-seral period ( $17-25$ years after severe bark beetle outbreak) and mature spruce forests in unmanaged montane/high-montane ecosystems in Southeastern Germany. We evaluated
\end{abstract}


the hypothesis that changes in structural heterogeneity and increases in diversity would peak in the initial stage and attenuate toward mature forest conditions by 17-25 years as the tree canopy closed.

We found a clear change in forest structural heterogeneity following the outbreak - most prominently in reduced cover and more clustered patterning of live trees, increased light availability, increased cover of shrubs and herbs, and high volume of dead wood. Most of these structural changes were not ephemeral after outbreaks, but remained high or even increased after multiple decades, suggesting persistence of early-seral heterogeneity well into succession.

Biodiversity as measured by species density and rarefaction curves showed variable responses to early-seral conditions depending on taxon and functional group. While some groups either showed no significant change with disturbance (e.g., most epigeics associated with the ground surface), or initially peaked after disturbance before declining quickly (e.g., saproxylic beetles specializing on fresh deadwood), several key groups showed maximum diversity in the advanced early-seral stage (e.g., herbs, herbivores, pollinators) - indicating that the timeframe over which increases occurred tended to be on the order of decades rather than years.

Our findings suggest that in unmanaged forests after bark beetle attack, a structurally complex phase prior to tree canopy closure can last several decades, and that many aspects of early-seral biodiversity and ecosystem function only fully develop given this extended time period. Where management of montane forests includes objectives for sustaining biodiversity, accommodating the protracted early-seral stage is important to supporting the full range of organisms and functions associated with canopy-opening disturbances.

Keywords: Homologous precocity; Structural heterogeneity; Arthropods; Vascular plants; Wooddecaying fungi; Berchtesgaden National Park

\section{Zusammenfassung}

Frühsukzessionale Waldökosysteme, die sich nach natürlichen Störungen, wie Feuer, Sturm oder Insektenbefall entwickeln, bergen oft eine Vielfalt an Prozessen, Habitatstrukturen und Arten. Die spezifischen Strukturen, die das frühe Sukzessionsstadium charakterisieren, der Effekt der Veränderungen auf verschiedene Artengruppen und der Zeithorizont, innerhalb dessen dieses Stadium dominiert, sind jedoch noch weitgehend unbekannt. Zur Bearbeitung dieser Fragestellungen wurden sowohl Bestandesstrukturen, als auch die Artenzahlen verschiedener Artengruppen von Pflanzen, Tieren und Pilzen in folgenden Entwicklungsstadien unbewirtschafteter Bergwälder der montanen/hochmontanen Höhenstufe in Südost-Deutschland untersucht: unbefallene sekundäre Fichtenaltbestände, Bestände der beginnenden Sukzession (ca. 3 Jahre nach Borkenkäferbefall) und 
Bestände der fortschreitenden Sukzession (17-25 Jahre nach Borkenkäferbefall). Nach unserer Hypothese sind ein Anstieg der strukturellen Heterogenität und eine Zunahme der Artenvielfalt in der beginnenden Sukzession zu erwarten, die aber bereits in der fortschreitenden Sukzession durch Schließen des Kronendachs wieder zurückgehen.

Die Bestandesstrukturen zeigten deutliche Veränderungen durch den Befall. Im Wesentlichen waren dies: geringere Überschirmung und größere Klumpung des lebenden Bestandes, größerer Strahlungsgenuss am Waldboden, größere Deckung der Kraut- und Strauchschicht und hohe Totholzvorräte. Die meisten strukturellen Veränderungen waren jedoch nicht nur kurzfristig nach dem Befall vorzufinden, sondern zeigten auch zwei Jahrzehnte nach der Störung noch zunehmende oder erhöhte Werte, und deuten damit ein Andauern dieser frühsukzessionalen Vielfalt in die weitere Sukzession an.

Artenzahlen und Artenakkumulationskurven, als Messgrößen der Biodiversität, zeigten je nach Art und funktioneller Gruppe unterschiedliche Reaktionen auf die frühsukzessionalen Verhältnisse. Während bei manchen funktionellen Gruppen keine Veränderungen (besonders bei den bodenbesiedelnden Arten), oder nur ein kurzfristiger Anstieg mit anschließendem Rückgang (wie bei den auf frisch abgestorbenes Totholz spezialisierten Käferarten) zu beobachten waren, zeigten einige wichtige Gruppen die höchsten Artenzahlen im Stadium der fortschreitenden Sukzession (z.B. Gefäßpflanzen, Pflanzenfresser und Bestäuber). Dies deutet darauf hin, dass bei Artengruppen, die von dem Störungsereignis profitieren, nicht nur mit einem Anstieg der Artenzahlen über einige Jahre, sondern eher über mehrere Jahrzehnte zu rechnen ist.

Unsere Ergebnisse deuten an, dass die strukturreiche Phase in unbewirtschafteten Wäldern nach Borkenkäferbefall mehrere Jahrzehnte bis zum Schließen des Kronendachs andauern kann, und dass viele Aspekte der frühsukzessionalen Biodiversität und der Ökosystemfunktionalität sich nur vollständig entwickeln können, wenn dieser ausgedehnte Zeitraum auch zur Verfügung steht. Wo die Bewirtschaftung der Bergwälder auch den Erhalt der Biodiversität zum Ziel hat, ist es wesentlich, die vollständige Entwicklung der frühsukzessionalen Phasen zuzulassen, um das gesamte Spektrum der Organismen und Funktionen zu unterstützen, die auf diese offenen bis lückigen Bedingungen nach Störungen angewiesen sind.

Schlagwörter: Waldentwicklungsstadien, Strukturelle Heterogenität, Arthropoden, Gefäßpflanzen, Totholzbesiedelnde Pilze, Nationalpark Berchtesgaden 


\section{Introduction}

Early-successional forest ecosystems have previously been considered as a short phase of stand initiation that plays only a minor role in ecosystem functioning and biodiversity (Bormann and Likens 1979, Franklin et al. 2002). However, young forest stands developing after natural disturbances, such as fire, windthrow or insect outbreaks, can support high diversity of habitat structures, species and processes - as such, this "forgotten stage of forest succession" has recently received much greater attention (Swanson et al. 2011). According to the habitat heterogeneity hypothesis, species diversity is positively correlated with habitat complexity (e.g., Tews et al. 2004, McElhinny et al. 2005). Indeed, in a recent extensive meta-analysis, Stein et al. (2014) showed a positive relationship between environmental heterogeneity and species richness across taxa, biomes and spatial scales. Thus, the high structural complexity characteristic of some early-seral post-disturbance forests (Donato et al. 2012) should also host high species diversity, as has been shown for insect communities after windthrow (Bouget and Duelli 2004).

The structural diversity of early-seral stands after disturbances is composed of legacies including dead wood derived from the pre-disturbance stand, the spatial and temporal variability of tree regeneration, and the co-dominance of diverse vegetation components including shrubs, herbs, and trees (Zenner 2005, Swanson et al. 2011, 2014). Structural variations in the initial successional stages may influence both biodiversity and forest development pathways over the longer term. According to the hypotheses posed by Donato et al. (2012), the rate and pattern of tree canopy closure following stand-replacing disturbances is a key factor: dense and synchronous tree establishment truncates the diverse early-seral phase quickly ('conventional pathway'), while sparse or protracted tree establishment allows structurally diverse conditions to develop ('analogous precocity pathway' due to certain structural similarities to old forests) and, if tree canopy closure never occurs, this diversity may persist throughout succession to the old-growth stage ('homologous precocity pathway'). These alternative pathways relate to the crucial question of longevity of the early-seral phase, which has conservation implications for species dependent on these ephemeral patches within larger landscapes (Swanson et al. 2014). Thus far, there have been few direct empirical tests of how various types of biodiversity develop and persist for multiple decades in early-seral forest communities - particularly the degree to which such biodiversity may indicate the persistence of structural complexity farther into succession than suggested by traditional models, which tend to focus solely on the conventional pathway of rapid uniform stand development (Donato et al. 2012).

Along with wildfire and windthrow, bark beetles (Curculionidae, Scolytinae) are one of the most important drivers of natural disturbances in forest ecosystems of the Northern Hemisphere. Between 1950 and 2000, bark beetles, mainly Ips typographus and Pityogenes chalcographus, caused mortality 
in about 2.9 million $\mathrm{m}^{3}$ of timber per year in European forests (Schelhaas et al. 2003). With changing climatic conditions, bark beetle activity is likely to increase when, under mild spring and dry summer conditions, species such as I. typographus and $P$. chalcographus are able to build up large populations even in high-elevation mountain forests (Krehan and Steyrer 2006, Jönsson and Bärring 2011). Following large-scale bark beetle disturbances, tree canopy closure and live phytomass are diminished significantly due to the dieback of mature trees, leading to higher solar radiation to the ground, more extreme temperatures, increased cover and height of the understory and often accelerated nutrient fluxes in the soil (Sousa 1984, Roberts 2004, Swanson et al. 2011). At the same time, large amounts of dead wood are created (Donato et al. 2013). If no forest management such as salvage logging or planting is applied, this early-seral stage is likely to support light-, nutrient-, deadwood- and flower-demanding species of arthropods and fungi, as well as disturbance-indicating autotrophs (Müller et al. 2008, 2010).

Biodiversity response can be measured in terms of alpha or beta diversity, reflecting, respectively, the number of species within a site or the differences in species composition among sites (Whittaker et al. 2001). In this study we focused on the alpha diversity response of several functional groups to canopy-opening by bark beetle outbreaks in the Alpine Berchtesgaden National Park, Germany. We assessed stand structure and species density of various taxa in mature spruce forests (no or only endemic beetle activity), initial early-seral vegetation ( $\sim 3$ years after severe bark beetle outbreak) and advanced early-seral vegetation ( 17-25 years after severe bark beetle outbreak) in unmanaged montane and high montane forests. We tested the following hypothesis: relative to mature forests, changes in structural heterogeneity and increases in compositional diversity following disturbance are strongest in the initial early-seral stage, and attenuate to intermediate levels by $\sim$ two decades (i.e., return toward pre-disturbance condition, consistent with a closed-canopy pathway) (Fig. 3.1). An alternative hypothesis states that structural heterogeneity and compositional diversity could remain elevated for several decades if an open-canopy pathway is followed for an extended period (Fig. 3.1). Our findings are then discussed in the context of management implications following severe beetle outbreaks in mountain forests.

\section{Methods}

\section{Study area}

The Berchtesgaden National Park, founded in 1978, is located in the south-eastern corner of Germany in the Northern Limestone Alps and covers an area of 20,800 ha (Fig. 3.2). With an altitudinal gradient from $603 \mathrm{~m}$ a.s.l. in the Königssee valley to $2,713 \mathrm{~m}$ a.s.l. at the top of the Watzmann massif, the mean annual temperature ranges from $+7{ }^{\circ} \mathrm{C}$ to $-2{ }^{\circ} \mathrm{C}$. Annual precipitation 
values vary between 1,500 and $2,600 \mathrm{~mm}$. The mean duration of snow cover increases from approximately 110 days in the valleys to 200 days at $1,500 \mathrm{~m}$ a.s.l. and 270 days at 2,000 $\mathrm{m}$ a.s.l. (Spandau 1988). The main soil types are rendzic leptosols of intermediate and shallow soil depth, eutric leptosols (humus layer $>15 \mathrm{~cm}-35 \mathrm{~cm}$ ) on steep slopes and chromic cambisols on less steep slopes and in the valleys.

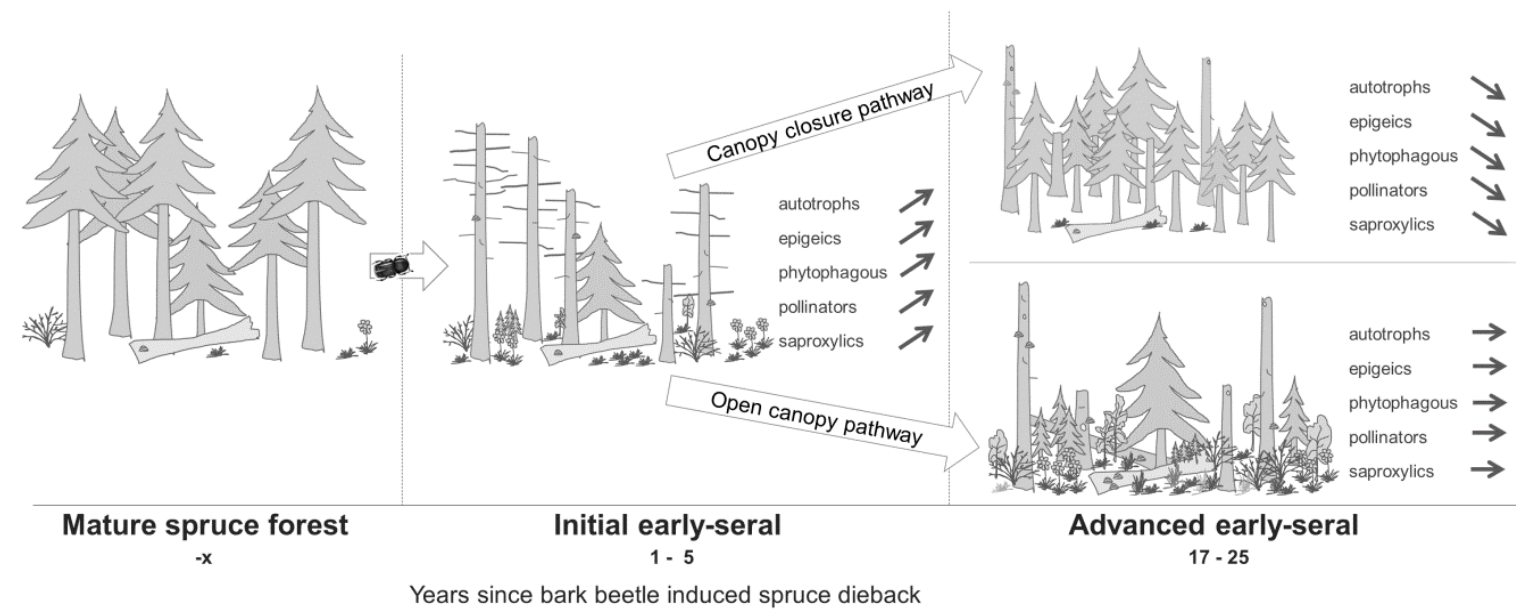

Fig. 3.1 Expected key structural elements and effects on alpha-diversity of different functional groups at three stages of forest succession before and after bark beetle induced spruce dieback.

Abb. 3.1 Erwartete Schlüsselstrukturen und Auswirkungen auf die Alpha-Diversität verschiedener funktioneller Gruppen in drei Entwicklungsstadien vor und nach Absterben von Fichtenaltbeständen durch Borkenkäferbefall.

The natural zonation of forest types in the region are mixed-montane European beech (Fagus sylvatica) forests with Norway spruce (Picea abies) and silver fir (Abies alba) at middle elevations, followed by Norway spruce - European larch (Larix decidua) - Swiss stone pine (Pinus cembra) forests in the subalpine zone (Köstler and Mayer 1974). As a result of a high demand for wood for salt mining in the past, the natural composition of these forests was heavily altered by humans over centuries at accessible sites, favoring pure Norway spruce stands (Knott et al. 1988, Konnert and Siegrist 2000).

In contrast to managed forests characterized by active control, salvage logging and, when necessary, regeneration measures after bark beetle outbreaks, no manipulation of natural forest dynamics has been taking place on approximately 6,000 ha of forest in the core zone of the National Park since 1978. Following the winter storms Vivian and Wiebke in 1990, around 100 ha of spruce stands were affected by spruce bark beetles (primarily I. typographus) between 1990 and 1997, consisting of nearly $100 \%$ mortality in patches of up to 1 ha in size. Dead trees were removed only within the bark beetle control zone of 1,900 ha at the border of the National Park in order to protect neighboring 
private forests from bark beetle infestation (Fig. 3.2). The outbreak ceased naturally at the end of the 1990s (Nationalpark Berchtesgaden 2001). Contrary to the preceding events, the winter storms Kyrill in 2007 and Emma in 2008 caused the most disturbance in the core zone, where no management takes place. Since then, approximately 400 ha of spruce stands have been infested by bark beetles.

\section{Study design}

No investigations of forest dynamics have been conducted in the National Park following the disturbances that occurred in the 1990s. Therefore no true time series analyses can yet be performed to study successional processes. Instead, we sampled three different stages of forest succession for this study, representing a chronosequence of unmanaged forests that characterize natural dynamics following spruce bark beetle attack. The three stages are: undisturbed secondary spruce stands that are approximately 80-250 years old and potentially susceptible to bark beetle infestation (mature stage), stands affected by bark beetles within the last five years (initial early-seral stage) and stands infested in the 1990s (advanced early-seral stage). Each stage was replicated six times in each of two altitudinal zones (montane and high montane) and on both south- and north-facing slopes, for a total of 72 plots ( 3 stages $\times 2$ zones $\times 2$ aspects $\times 6$ replications).

As the size of the 1990s bark beetle gaps rarely exceeded one hectare, only gaps with dimensions of 0.1 - 1.0 ha were chosen for comparison for this stand-scale study. Plots were selected using aerial photographs from 1990, 1997, 2009 and 2012, which were verified in the field. Circular study plots 0.05 ha in size were located in the center of bark beetle gaps for the initial and advanced early-seral sites. Mature spruce stands were represented by study plots located on those grid points of the National Park forest inventory (Konnert and Siegrist 2000) that were spruce-dominated and closest to the selected bark beetle gaps. Half of the study plots (category 1) were investigated in detail, with structural attributes and all diversity characteristics. On the study plots of category 2 , only structural attributes and vascular plants were recorded, due to time and resource constraints. Study plots of both categories were distributed over the entire spruce-dominated area of the National Park (Fig 3.2). Study plots were selected among areas of known disturbance history regardless of apparent structural or compositional appearances, as such metrics of plant composition and forest structure were, like the animal and fungal metrics, true response variables.

\section{Data collection}

Stand structural attributes including live standing and dead wood volume were measured following standard forest measurement procedures on all study plots (Konnert and Siegrist 2000), including tree bole location, diameter at breast height and tree height measurements of all trees taller than two meters in height. Existing allometric equations for Bavaria were used to calculate living stand 
and dead wood volume (Kennel 1973). The decay stage of dead wood was recorded in the field using a six-category classification scheme ranging from 0 (dying) to 5 (mostly decayed). Gap age was reconstructed and gap size was measured using aerial photographs. The relative amount of direct radiation compared to open field conditions (direct site factor - DSF) was estimated with hemispherical photography, taking eight pictures per plot during overcast sky conditions at fixed positions with a lens height of one meter above ground. The pictures were analyzed using the WinSCANOPY software (Regents Instruments Inc 2003). The threshold grey scale values separating sky, forest, or slope pixels were defined via calibrated segmentation (Wagner 1998, 2001).

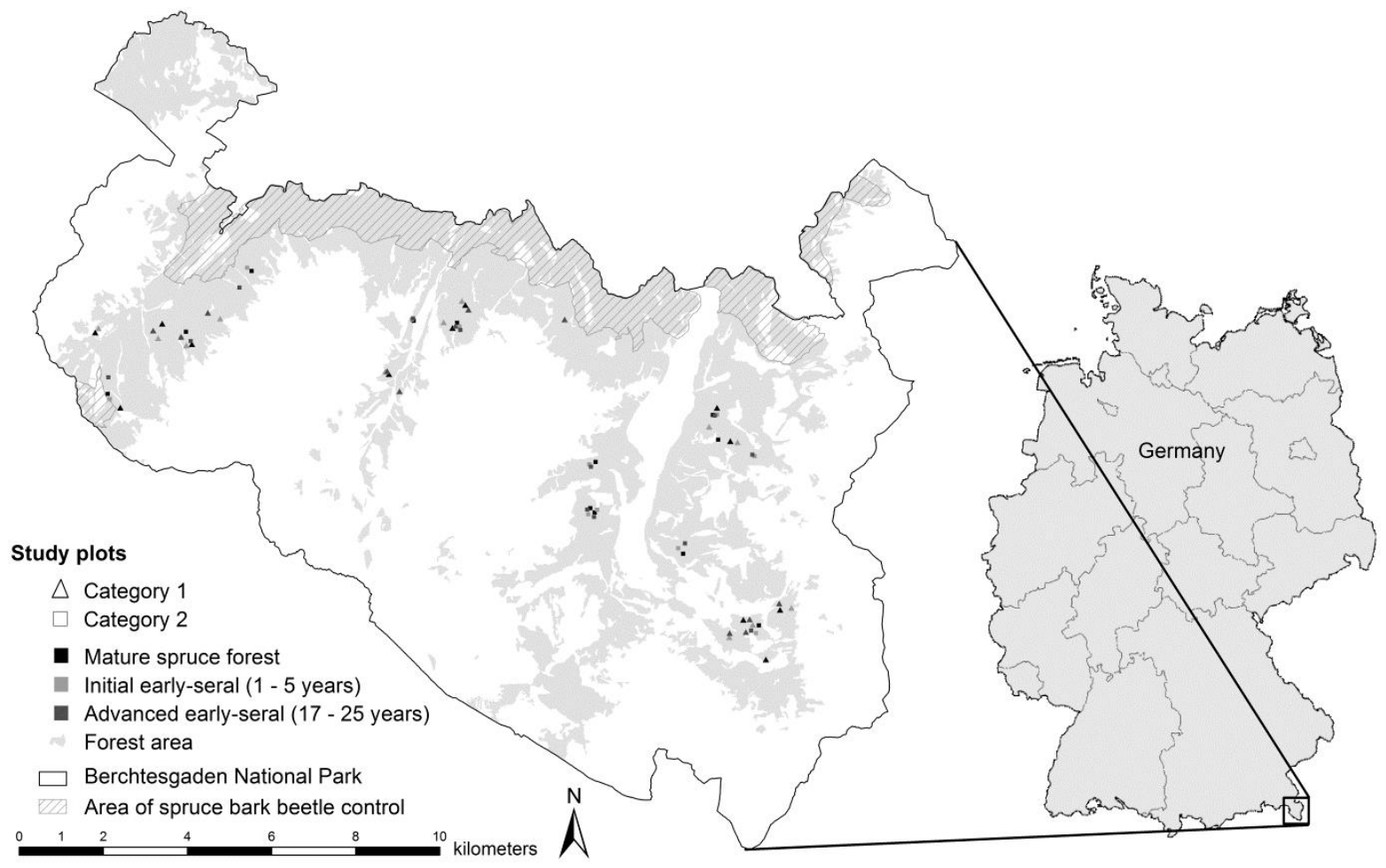

Fig. 3.2 Study area, Berchtesgaden National Park in South-Eastern Germany, showing the distribution of forest area and the location of the 72 study plots.

Abb. 3.2 Das Untersuchungsgebiet mit Ausdehnung der Waldfläche und Lage der 72 Probeflächen im Nationalpark Berchtesgaden im Südosten Deutschlands.

Vascular plants were mapped once on each of the 72 study plots in May to July 2012 or May to July 2013, by mapping all species and the area they cover in different layers on the plot (herb layer, shrub layer, tree layer) in seven cover classes, following the method of Braun-Blanquet (1964). Arthropods were sampled on the 36 category 1 study plots during the growing season of 2012 (May-September) using two pitfall traps and one flight interception trap per plot. The pitfall traps consisted of a 0.5 I plastic cup sunk into the ground, with rim leveled with the soil surface. Approximately $10 \mathrm{~cm}$ above the cup, a transparent plastic roof was attached to exclude rain water and to prevent a dilution or overflow of the preservative. The flight interception traps were constructed with a crossed pair of 
transparent plastic shields $(40 \times 60 \mathrm{~cm}$, with yellow tape at the lower end to attract flower-visiting species), a funnel with sampling jar at the bottom, and a plastic roof at the top. They were hung between two trees with an upper height of $1.3 \mathrm{~m}$. Both trap types were filled with $2 \%$ copper-sulfate solution as a killing and preserving agent. The traps were emptied monthly during the growing season and specimens of the different taxonomic groups (Coleoptera, Arachnida, Collembola, Heteroptera, Aculeata (without Formicidae), and Mollusca) were determined to the species level by external specialists. Wood-decaying fungi were sampled on the 36 category 1 study plots during a three-week period in August and September 2013. The macroscopic survey of fruiting bodies was standardized per plot to 90 minutes. First, the proportion of each dead wood substrate (tree, snag, log, stump, branches) was estimated per plot, followed by the sampling of each dead wood substrate representative to its occurrence on the plot, with as many objects as possible within the time frame. The fungi found were identified to species level in the field or in the laboratory.

\section{Statistical analysis}

The taxonomic groups were sorted into functional groups, depending on their main ecological features. The functional species groups assigned were autotrophs (primary producers; in our case: vascular plants), epigeics (organisms whose activities are concentrated above the soil surface), phytophagous (those that consume live plant matter), pollinators (vectors for pollen between plants or plant populations) and saproxylics (those dependent on dead wood) (Table 3.1). Beetle species present in several functional groups (e.g., Stenurella melanura, whose larvae develop in rotten wood and adults feed on pollen and nectar) were considered in each of the respective functional groups.

To assess horizontal stand structure, the aggregation index R of Clark and Evans (1954) was calculated for the spatial distribution of live trees within each plot, using the Cumulative Distribution Function method (Baddeley et al. 2014) to correct for edge effects. Values of $R>1$ indicate a regular/dispersed distribution relative to random, while values of $R<1$ suggest clustering of the trees on the plot relative to random. The mean tree height and the range between the first $\left(Q_{1}\right)$ and the third $\left(Q_{3}\right)$ quartile of tree heights per plot were calculated to analyze differences in vertical stand structure among the three successional stages. The cover of vegetation layers, given as percentage, was transformed with arc-sine square-root transformation before analysis (Sokal and Rohlf 1995).

The assumption of independence between the three succession stages and each of the structural response variables was assessed by means of resampling-based multiple testing (Westfall and Young, 1993). The $p$-values obtained by this procedure are adjusted for multiple comparisons utilizing a step-down max-T approach (Algorithm 2.8 in Westfall and Young, 1993). For each response variable, 
a post-hoc test (Tukey all-pair comparisons) was applied additionally in order to assess the differences of the rank-transformed response variables between each pair of categories.

In order to use the same diversity measure for trap data (faunistic species groups) as for mapping data (vascular plants and wood-decaying fungi), species densities, which are the number of species per specified collection unit (here: study plot) (Magurran 2004), were used as a measure of alpha diversity in this study. Species densities, being count data, were tested with quasi-poisson models and a post-hoc test for differences among the successional stages, altitudinal zones and aspects. In a parallel analysis, we standardized the number of species observed to the number of individuals (for the abundance dataset of fauna), respectively records (for the presence-absence dataset of flora and fungi), sampled, using rarified species accumulation curves (Gotelli and Colwell 2001). We also calculated the inverse Simpson index (1/D) following Jost (2006), and compared it between the three successional stages; those results are not shown as they did not differ substantially from the analysis of species densities. Associations between structural, floristic, faunistic and fungal attributes were analyzed by calculation of Spearman`s rank correlation coefficients (Sokal and Rohlf 1995).

To detect and describe associations between individual species and specific successional stage(s) an Indicator Species Analysis (Dufrêne and Legendre 1997) was calculated for all species of flora, fauna and fungi. This method produces an indicator value (IV) for each species by combining information on the concentration of species abundance in a particular stage and the constancy of occurrence of a species in a particular stage. Constancy describes the ratio of plots where the species is present; abundance depicts the sum of individuals (for fauna und fungi), or the area covered in $\mathrm{m}^{2}$ for flora (calculated from the mean value of the Braun-Blanquet cover classes) of plots of a given successional stage. Indicator values were computed for each species in each stage and tested for statistical significance via 10,000 permutations. Species composition of vascular plants was analyzed additionally by calculating mean cover-weighted indicator values of light $(\mathrm{L})$ and nutrients $(\mathrm{N})$ per plot (Ellenberg and Leuschner 2010) and by evaluating the proportion of the plot area covered by plant species of different forest habitats (closed forest, forest gaps and edges, open area; Schmidt et al. 2011).

All statistical calculations were performed in statistical framework R 3.1.0 using the add-on packages "vegan" (for community ecology analyses; Oksanen et al. 2012), "multcomp" (for general parametric modeling; Hothorn et al. 2013), "spatstat" (for spatial point pattern analysis; Baddeley et al. 2014), "indicspecies" (for statistical analysis of relationship between species and groups of sites; De Cáceres and Jansen 2014) and "coin" (for permutation tests; Hothorn et al. 2014). The level of significance for all statistical inferences was defined with $\alpha \leq 0.05$. 


\section{Results}

In total we identified 587 species of arthropods and mollusks (23,944 specimens), 262 species of wood-decaying fungi (1,317 records) and 326 vascular plant species $(5,444$ records, Table 3.1$)$.

Table 3.1 Studied species groups within the observed functional groups with species density and abundance. Species density is the number of species, and abundance is the total number of individuals detected across the study for fauna and fungi, and the number of records for flora.

Tabelle 3.1 Untersuchte Artengruppen innerhalb der funktionellen Gruppen mit Artenzahlen und Abundanzen. Species density gibt die Anzahl an Arten wider, abundances stellt die Anzahl der Individuen (von Tieren und Pilzen) bzw. Kartierungen (von Pflanzen) dar, die innerhalb dieser Studie erfasst wurden.

\begin{tabular}{llrr} 
Functional group & Species group & Species density & Abundance \\
\hline autotrophs & herb layer & 287 & 4,627 \\
& shrub layer & 20 & 412 \\
& tree layer & 19 & 405 \\
\hline epigeics & epigeic beetles & 108 & 6,260 \\
& spiders & 129 & 3,919 \\
& mollusks & 47 & 2,152 \\
& springtails & 21 & 6,872 \\
\hline phytophagous & phytophagous beetles & 104 & 2,477 \\
& true bugs & 24 & 131 \\
\hline pollinators & pollinating beetles & 37 & 244 \\
& pollinating Aculeata & 28 & 124 \\
\hline \multirow{2}{*}{ saproxylics } & saproxylic beetles of early decay stages & 49 & 1,516 \\
& saproxylic beetles of advanced decay stages & 91 & 526 \\
& wood-decaying fungi & 262 & 1,317 \\
\hline
\end{tabular}

\section{Stand structure}

Most metrics of stand structure changed significantly with beetle disturbance, but then stayed at similar levels over the first 25 years of succession (Table 3.2). Solar radiation to the ground, live tree stand volume, horizontal stand heterogeneity (Clark and Evan aggregation index), vertical stand heterogeneity (tree height distribution) and herb cover differed significantly between the mature stand and the two early-successional stages. Shrub coverage did not differ between mature forests and the initial early-seral stage, but was significantly higher in the advanced early-seral stage. Tree cover remained lower than that of mature stands even after multiple decades since outbreak. Stands affected by bark beetles had lower stand volume and more uniform vertical stand structure than the mature plots, but had significantly higher direct radiation at the forest floor, dead wood volume and 
horizontal heterogeneity (Table 3.2). All three successional stages indicated clustering of the trees on the plot with values of $R<1$, but the clustering was significantly more evident in the post-disturbance stages compared to the mature forests.

The initial early-seral stage was characterized by an abundance of relatively sound (fresh) dead wood, advanced early-seral stage stands contained mainly well decayed wood, and mature forests contained the most even distribution of all stages of decay (albeit with much lower volumes) (Table 3.2). Relative direct radiation to the ground was positively correlated to dead wood volume (Spearman rank correlation index 0.69, $p=0.000$ ) and the cover and height of herbs and shrubs (Table 3.3 ), but negatively correlated to live tree stand volume $(-0.79, p=0.000)$, Clark and Evans aggregation index $\mathrm{R}(-0.53, p=0.003)$ and tree height $(-0.46, p=0.01)$. The cover of the tree layer was strongly linked with other attributes expected to influence habitat conditions. We found negative correlations between tree cover and the amount of direct radiation to the ground $(-0.66, p=$ $0.000)$, herb cover $(-0.4, p=0.029)$, and understory vegetation height $(-0.44, p=0.016)$, but a positive correlation with the ground coverage of litter $(0.49, p=0.006)$.

\section{Autotrophs}

Several characteristics of the vascular plant community changed with disturbance and continued to diverge from, rather than return toward, those of mature forests over the first 25 years after beetle outbreak (Fig. 3.3). In post-disturbance stands, the species density of the herb layer was higher than on the mature plots. Species density of shrub species did not differ between mature forests and the initial early-seral stage, but was significantly higher in the advanced early-seral stage (Fig. 3.3). Also the mean cover of insect-pollinated plant species was significantly higher in the advanced early-seral stage, compared to the mature spruce forests (data not shown). Tree species density was very low (median $=2$ ) and did not differ significantly among the successional species (Fig. 3.3). Rarefaction curves indicate that the number of plant species represented by a given number of individuals was initially unchanged by beetle outbreak, but later increased by the advanced early-seral stage to greater than either of the other two conditions (Fig. 3.4).

Elevation or aspect did not change the overall pattern of species density of autotrophs across successional stages. Similarly, species density did not differ significantly between north- and southfacing slopes. Significantly higher species densities occurred, however, on high montane sites ( median $=83$ species) compared to montane sites (median $=70$ species). 


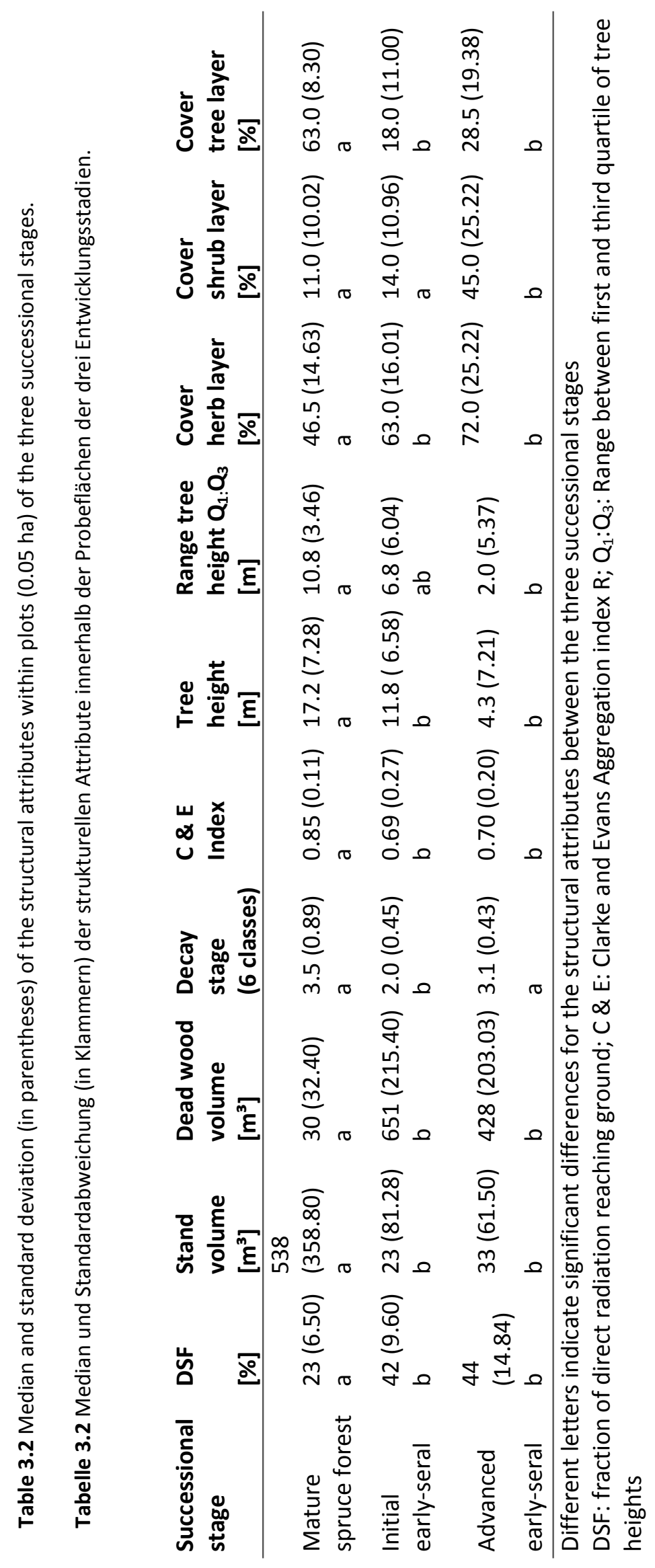




\section{Autotrophs}

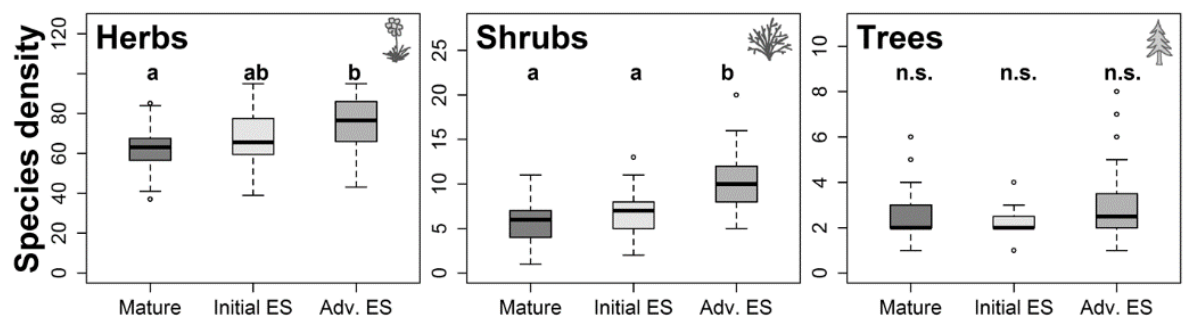

Epigaics

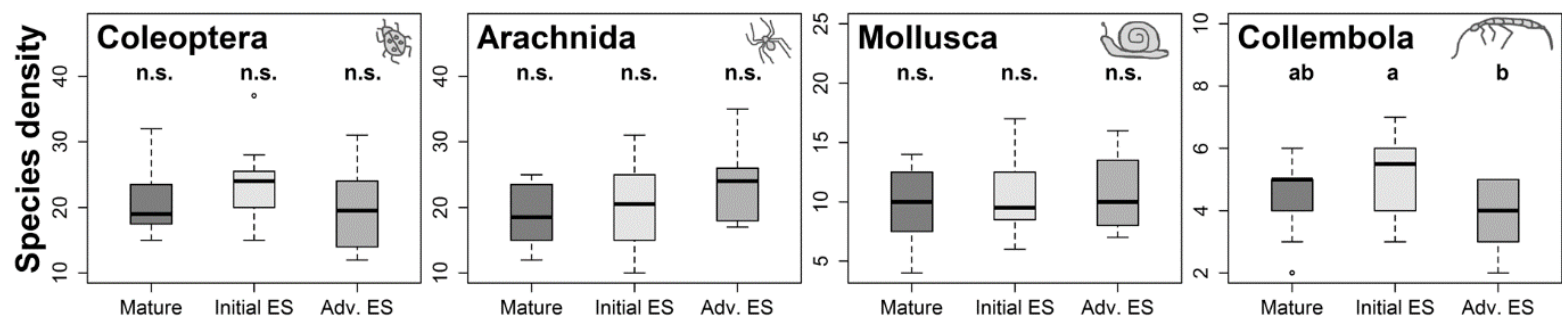

Phytophagous
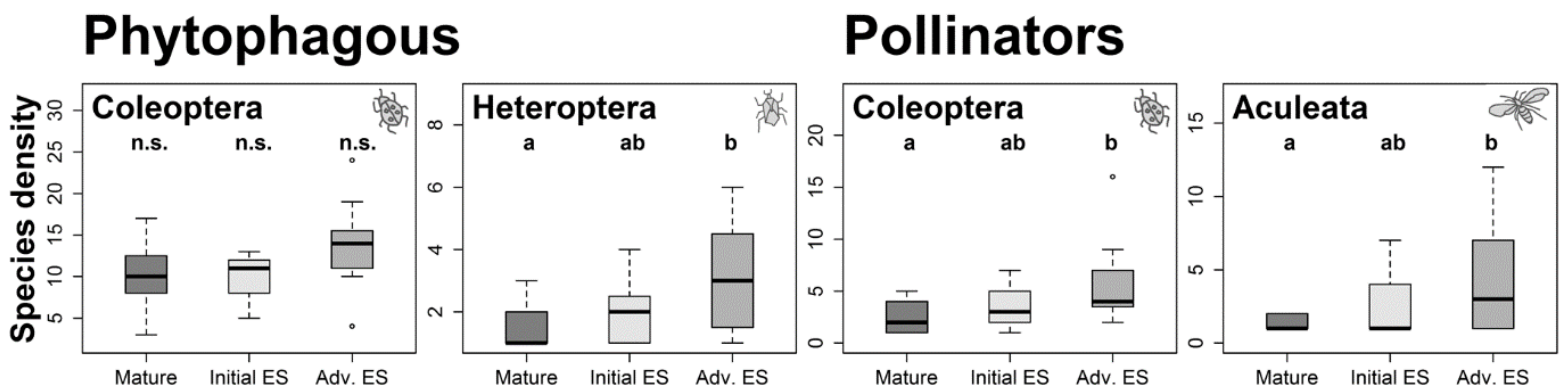

\section{Saproxylics}

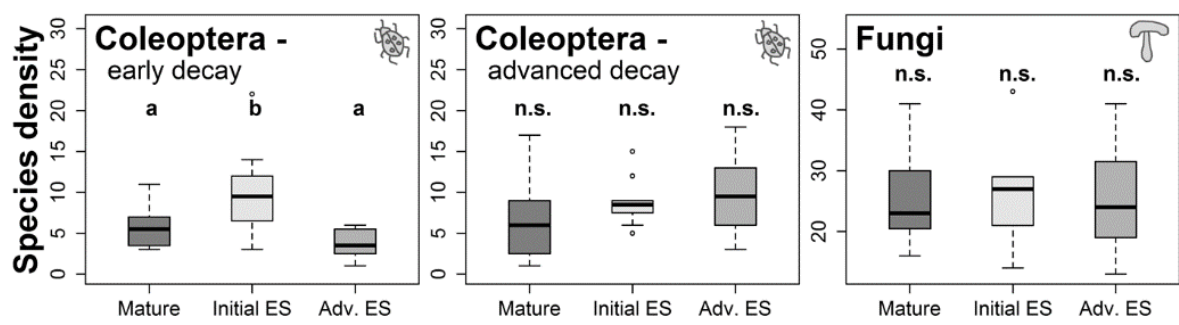

Fig. 3.3 Species density of functional species groups in the three successional stages (Initial ES: Initial earlyseral, Adv. ES: Advanced early-seral). Different letters above the boxplots indicate significant differences.

Abb. 3.3 Artenzahlen der funktionellen Artengruppen in den drei Entwicklungsstadien (Mature: Fichtenaltbestand, Initial ES: beginnende Sukzession, Adv. ES: fortschreitende Sukzession). Unterschiedliche Kleinbuchstaben oberhalb der Boxplots kennzeichnen signifikante Unterschiede.

The species composition of vascular plants shifted towards assemblages preferring more nutrientrich site conditions during the first 25 years of post-disturbance succession. The cover-weighted mean Ellenberg-indicator-value for nutrients $(\mathrm{N})$ showed significantly higher numbers on the advanced early-seral plots (median $(s d)=5.4(0.94))$ than on the mature plots $(4.2(0.79))$, with the initial early-seral plots being in the middle without significant differences $(4.8(0.92))$. Mean lightindicator values did not differ among the three stages (data not shown). However, the mean area covered with plant species commonly associated with forest gaps and forest edges (according to the 
list of forest species of Schmidt et al. (2011)) was significantly different between the different stand types, shifting from $5 \%(s d=3.78)$ in the mature stage to significantly higher in the initial $(13 \%$ (8.33)) and the advanced early-seral stands (19.5\% (12.60)). Similarly, the indicator species analyses revealed more nutrient and light demanding indicator species of autotrophs in the post-disturbance stages, compared to the mature forest stands, combined with an overall increase in the number of indicator species detected with ongoing succession (Table 3.4). No significant differences appeared in the number of red-listed plant species present on the plots of the three successional stages (data not shown).
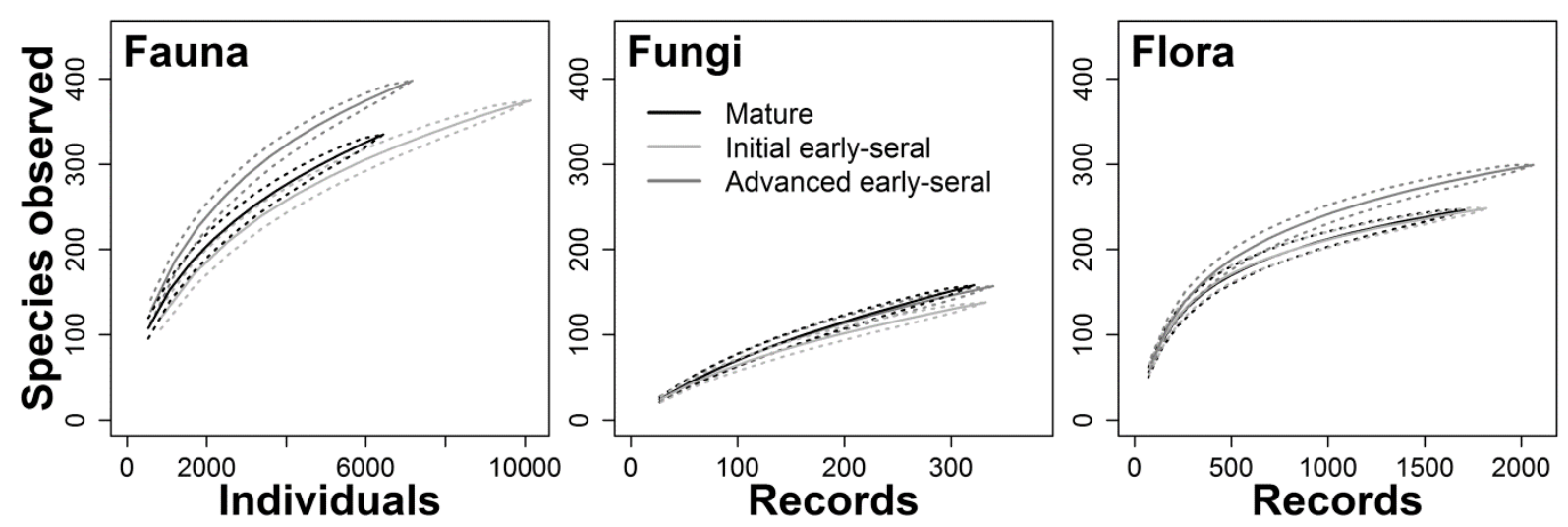

Fig. 3.4 Rarefaction curves of fauna (combined studied functional groups), fungi and flora. Dotted lines indicate upper and lower bound of confidence interval. Curves of fauna are based on abundances; curves of fungi \& flora are generated with presence-absence data.

Abb. 3.4 Arten-Akkumulationskurven von Tieren (Kombination der untersuchten funktionellen Gruppen), Pilzen und Pflanzen. Die gestrichelten Linien kennzeichnen die untere und obere Grenze des Konfidenzintervalls. Die Kurven der Tiere basieren auf Abundanzdaten, die Kurven von Pilzen und Pflanzen auf Präsenz-Absenz-Daten.

\section{Fauna and Fungi}

Fauna and fungi showed variable trends with successional stage. Most epigeic species groups did not show significant differences in species density among the three successional stages. However, the highest species density of springtails (Collembola) was found on the initial early-seral plots (Fig. 3.3). For phytophagous species and pollinators, we found a significant increase in species densities from mature to both the early-successional stages for true bugs (Heteroptera), pollinating beetles and pollinating bees and wasps (Aculeata; Fig. 3.3). Species density of all studied groups of saproxylics, including fungi, tended to peak during the initial early-seral phase, but only the saproxylic beetles (Coleoptera) that prefer relatively undecayed dead wood showed significant differences (Fig 3.3). 


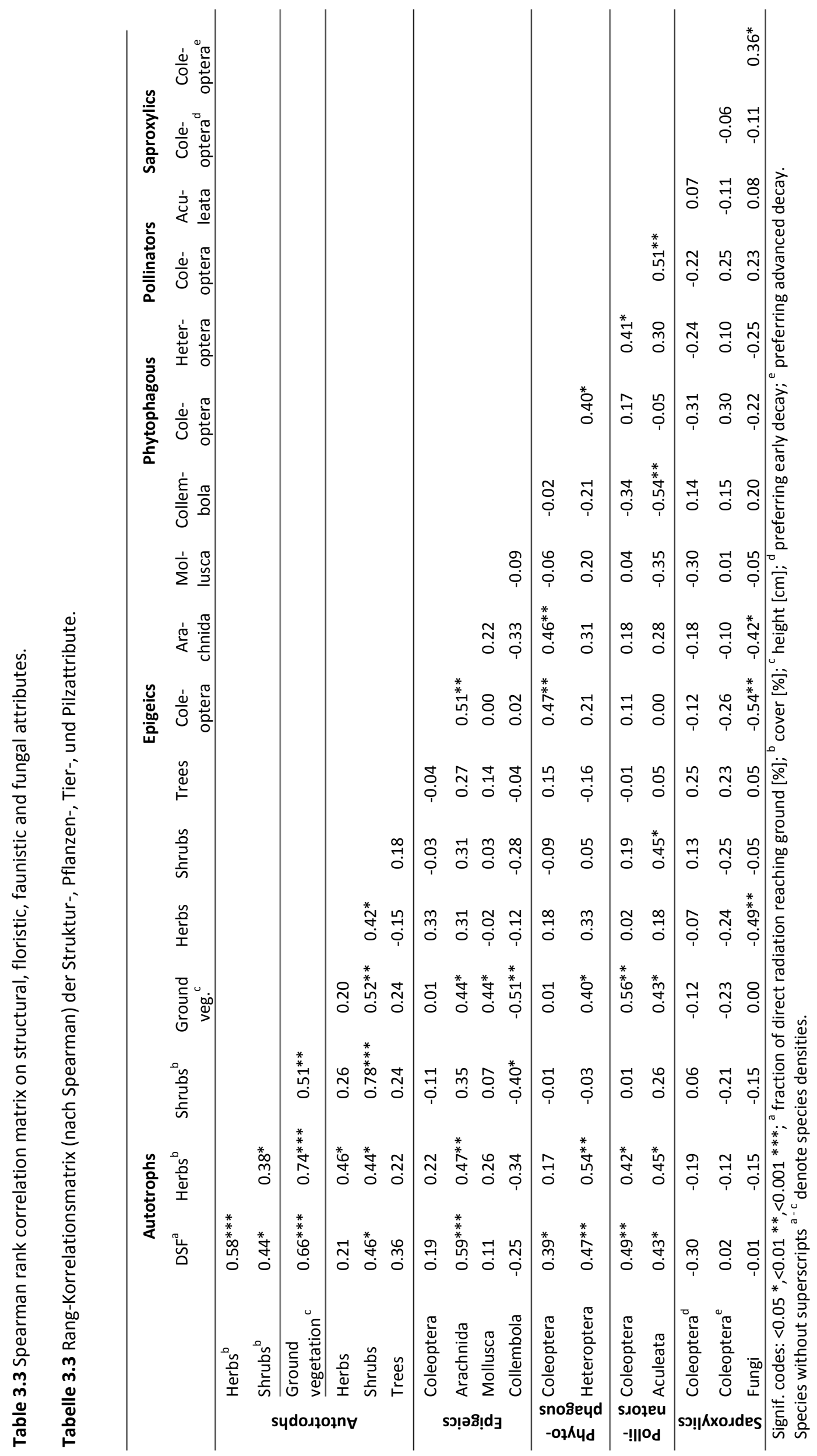


The indicator species analysis revealed a preference of the majority of saproxylic indicator species to the initial early-seral stage, but for the epigaic and pollinating indicator species to the advanced early-seral stage. The few indicator species of the phytophagous were largely evenly distributed among the successional stages (Table 3.4). Rarefaction curves indicated a minor decrease in overall fauna species per number of individuals in the initial early-seral phase, followed by a significant increase in advanced early-seral stands relative to both other conditions (Fig. 3.4). The rarefaction response for fungi was largely the same across successional stages (Fig. 3.4). There were no significant differences in species density of functional groups between montane and high montane elevations, nor between north- and south-facing slopes; elevation or aspect also did not change the shape of the species density trend among the successional stages. None of the functional groups of faunistic and fungal species showed significant differences in the presence of red-listed species among the different successional stages (data not shown).

Interactions between forest structure, vascular plants and functional groups of fauna and fungi

Spearman rank correlations between structural attributes and functional groups showed significant positive relationships between direct radiation to the ground and the species density of phytophagous and pollinating species (Table 3.3). Measures of horizontal and vertical stand structure (Clark \& Evans R and tree height distribution) did not show significant correlations to species densities of the functional groups (data not shown). Likewise, no significant correlation was apparent between the species density of autotrophs and those of the phytophagous species groups. However, the true bugs, pollinating beetles, bees and wasps showed significant positive correlations with the cover and height of the herb layer. Significant negative correlation coefficients occurred between the epigeic springtails and shrub cover and height of vascular plants (Table 3.3).

\section{Discussion}

This study of bark beetle-induced forest succession showed a clear change in forest structural heterogeneity following severe outbreaks - most prominently in reduced cover and more clustered patterning of live trees, increased light availability at the surface, increased cover of shrubs and herbs, and high volume of dead wood. Perhaps most notably, most of these structural changes were not ephemeral after outbreaks; rather, they remained high or even higher after multiple decades of succession, suggesting persistence of early-seral heterogeneity well into succession. The data largely support the alternative hypothesis of prolonged development of early-seral diversity during an extended open-canopy period. Biodiversity as measured by species density showed variable responses to early-seral conditions depending on species and functional group, but for some of the most responsive groups (e.g., pollinators and insect-pollinated plants), the timeframe over which 
increases occurred tended to be on the order of decades rather than years. These findings suggest that a structurally complex phase prior to tree canopy closure can be a multi-decade period, and that this extended period of open conditions allows for full development of early-seral diversity and ecosystem function. In the following sections we discuss the responses of different functional groups among the successional stages, and then synthesize these with observed structural changes and implications for ecosystem development.

\section{Increasing diversity of vascular plants}

Summed across all vegetation layers, these data showed a significant increase in species density of vascular plants during the first 25 years of bark beetle-induced forest succession, and a change in the species composition towards light- and nitrogen-demanding plant species (Fig. 3.4, Table 3.4). It is known that the species density of ground vegetation can increase with increasing light conditions (Ammer 1996) and that the improved light availability in the early-seral stage promotes lightdemanding species (Lehnert et al. 2013).

Even small-scale disturbances causing only minor changes in light and soil conditions can result in considerable changes in ground-layer vegetation in mountain spruce forests (Holeska 2003). Increased mineralization rates during the first years after bark beetle-induced spruce dieback locally increase nitrogen $\left(\mathrm{NO}_{3}^{-}\right)$release (Huber 2005), which in turn promotes nitrophilous plant species (depending, in part, on soil pH; Sayer and Reif 1998, Ewald et al. 2011). Other studies have shown that the presence of soil-surface disturbances, such as pit-and-mound topography created by uprooted trees, may be even more important in creating diverse microsites for vegetation establishment and growth (Kupferschmid Albisetti 2003, Ewald et al. 2011, Fischer and Fischer 2012, Fischer et al. 2012).

Differences among successional changes might have been even more pronounced in this study, if the percent cover of plant species were mapped on the plots, instead of the cover-abundance scores of the Braun-Blanquet classification. Mapping the true percent cover of all individual plant species on 0.05 ha large study plots is, however, prone to estimation errors. For this reason, the more conservative method of the Braun-Blanquet classification was applied. 


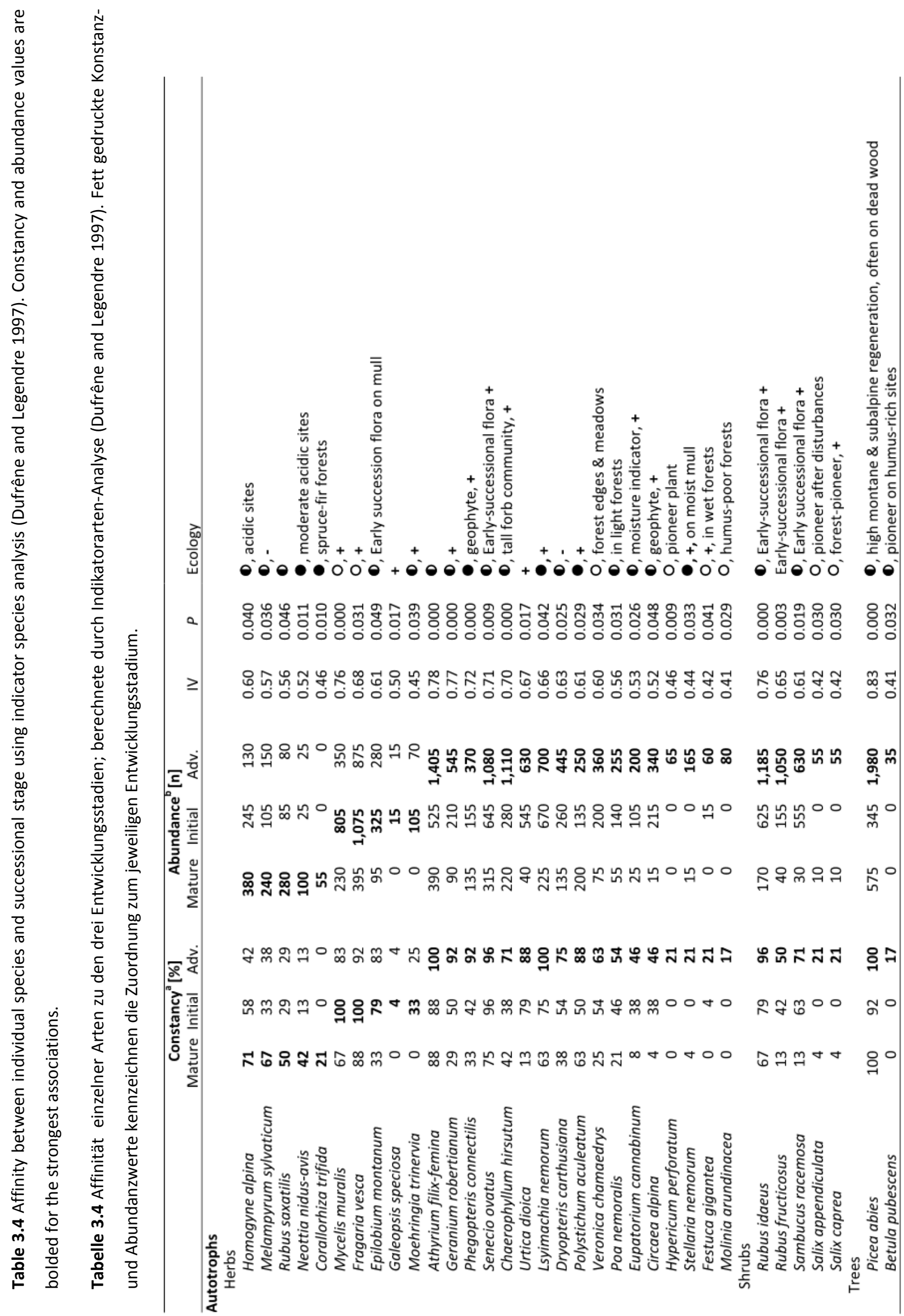




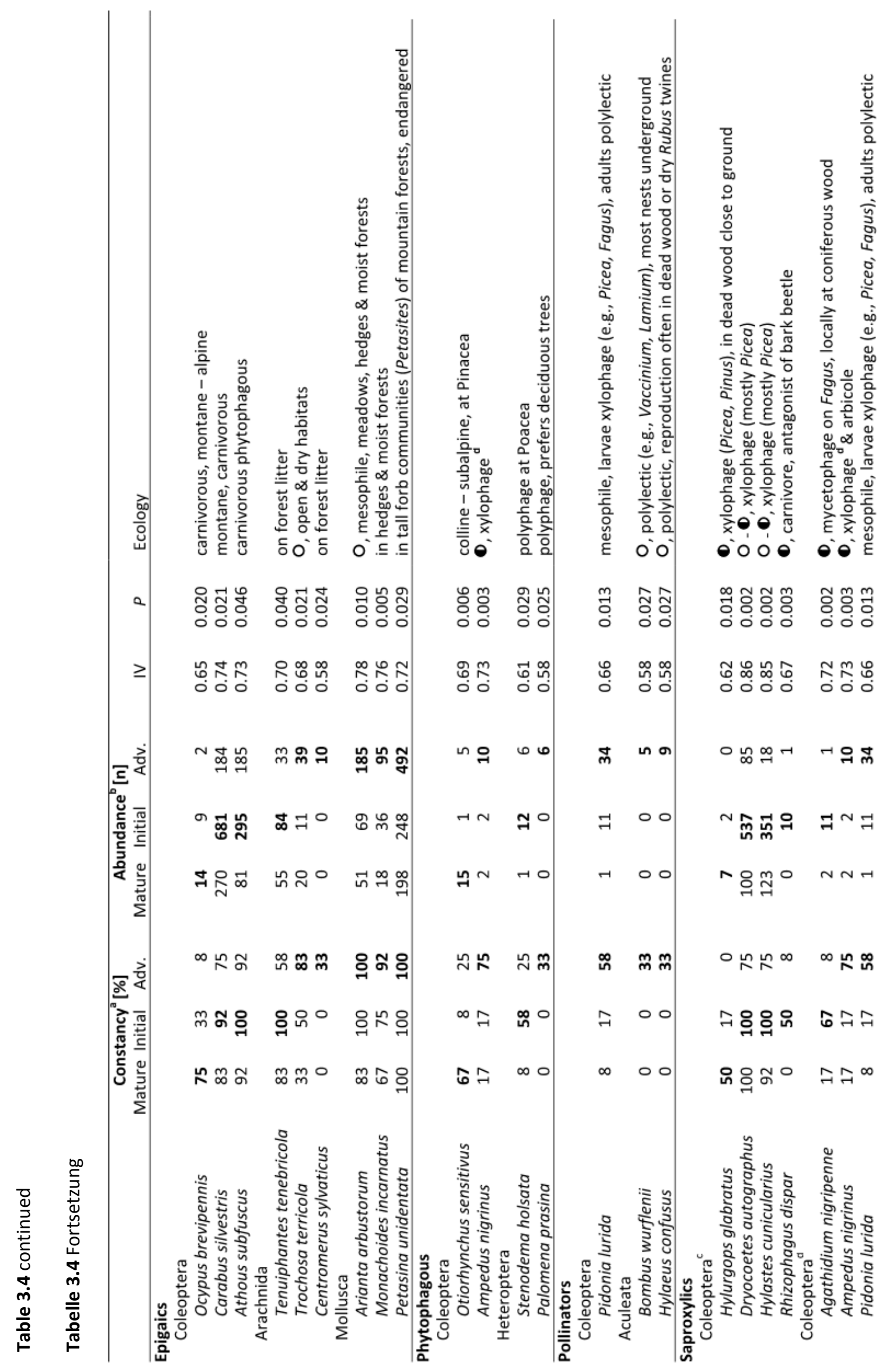




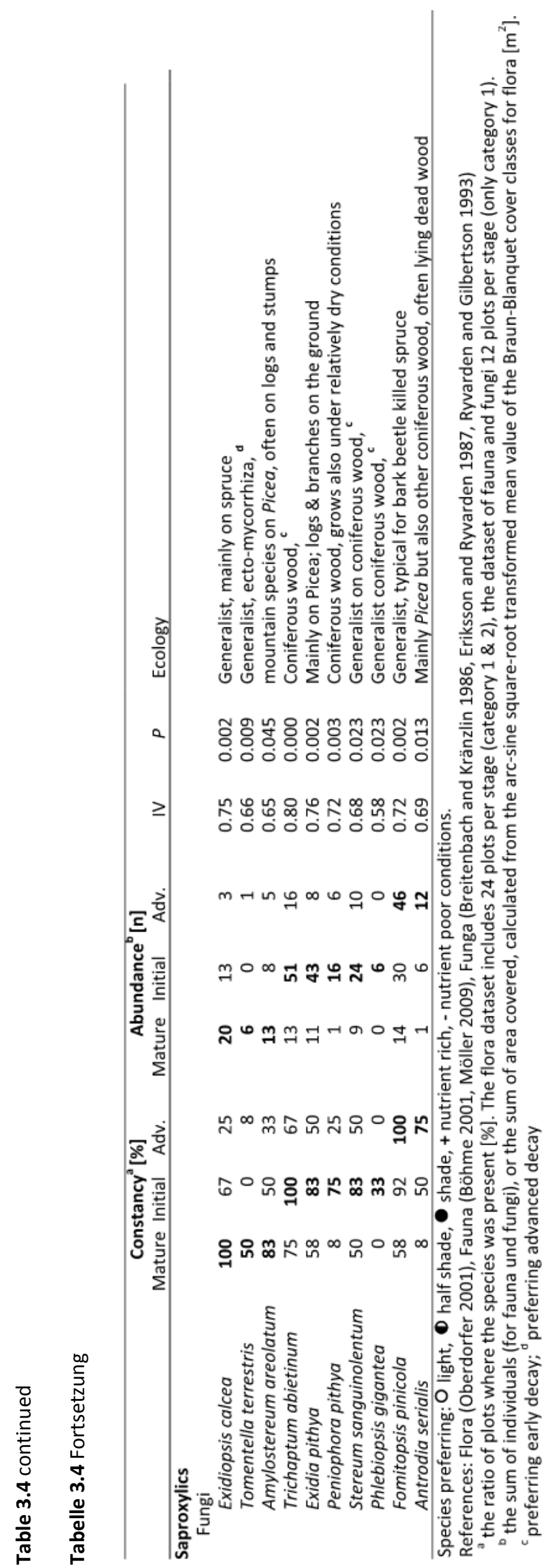




\section{Weak response of epigeic insects}

Our hypothesis that epigeic species density would increase in early-seral stands relative to mature forests was largely unsupported. The diversity of epigeic beetles tended to peak in the initial earlyseral stage, but the differences were not statistically significant. Kenter et al. (1998) found higher species densities and abundances of epigeic beetles (Carabidae and Staphilinidae) on windthrown sites, due to higher structural diversity compared to adjacent mature spruce stands.

Species and specimen numbers declined with increasing cover of vegetation and successional development of plant species composition (Kenter et al. 1998), with the Carabidae returning almost completely to composition characteristics of an undisturbed community within six years (Fischer et al. 1998).

Species density of spider assemblages is known to increase with decreasing tree canopy cover (Vierling et al. 2011), but increasing plant species density (Mrzljak and Wiegleb 2000). Both conditions (low tree cover and high plant diversity) can be found in our early-seral stages. Although we observed a trend of increasing species density of spiders over early succession, this trend was not significant.

Attributes known to positively affect species density of mollusks include temperature, tree age and canopy height, dead wood of advanced decay and the presence of wood-decaying fungi, density of plant species and habitat structure (Barker and Mayhill 1999, Aubry 2005, Müller et al. 2005, 2009, Rieger et al. 2010). While our mature spruce stands are represented by greater tree ages and canopy heights, but lower dead wood volumes and plant species density, the early-seral stages show the opposite conditions (see Table 3.2 and Fig. 3.3). This might explain why no significant differences in mollusk species density can be found in our study. It is, however, consistent with results from calcareous windthrown sites in Southwestern Germany, where no differences in species density of mollusks among the disturbed sites and adjacent mature spruce forests were observed (Spelda et al. 1998).

Springtails have been shown to positively respond to inputs of dead wood and litter (Ulyshen et al. 2011), but might also benefit from a richer herb layer (Salamon et al. 2008). In our study the species density of springtails peaked in initial early-seral stands, which are characterized by higher volume of dead wood and litter needle-fall of the dead spruce trees. The increasing height of the ground vegetation is, however, negatively correlated with the species density of springtails (see Table 3.3) and might be, together with the diminished amount of coniferous litter, an explanation for the decline of the species density of springtails in the advanced early-seral stage. 
Increases in phytophagous and pollinating species

Phytophagous species density remained similarly diverse in the initial early-seral stage relative to mature forests, and then increased to the highest level in advanced early-seral conditions. The preference of pollinators for the advanced early-seral stage was shown by both an increase in species density and a majority of indicator species (Fig. 3.3, Table 3.4). Of the studied functional groups in our study, phytophagous and pollinating species were among the main positive responses following spruce overstory dieback. This trend is likely associated with high ecosystem-averaged specific leaf area (SLA) that can develop in early-seral communities due to co-dominance of broadleaf and conifer species, which in turn can support more secondary production by consumers (Campbell and Donato 2014). This relationship between primary and secondary ecosystem production is also evident in the parallel increases in pollinators and insect-pollinated plant species. In addition, interior forest edges as created by bark beetle gaps are known hotspots of insect biodiversity, including beetles, true bugs, Aculeata and lacewings (Müller et al. 2007). The improved light availability favors light-demanding plant species alongside insect species of various taxa and life histories (Lehnert et al. 2013).

\section{Short-term window for saproxylic species}

The increasing amount of spruce dead wood and the opening of the canopy by bark beetles have positive effects on the abundance of host-generalist and conifer-specialist guilds of saproxylic beetles, among them red-list species (Müller et al. 2008, 2010). Due to decreasing amounts of nutrients in decaying woody debris, the attractiveness of dead wood (especially coniferous wood; Saint-German et al. 2007) to saproxylic beetles decreases over time (Kopf and Funke 1998). Consistent with these previous studies, we found the highest numbers of saproxylic beetles preferring wood of early decay stages in the initial early-seral stage following the availability of fresh dead wood. By the advanced early-seral stage, dead wood has further decayed beyond the habitat suitability for those species, but probably not conceivably enough for those beetles depending on dead wood of advanced decay stages.

Species density of wood-decaying fungi is known to increase with the amount and diversity of coarse woody debris (Sippola et al. 2004, Küffer and Senn-Irlet 2005, Lonsdale et al. 2008, Bässler et al. 2012). Studies on windthrow areas in Southwestern Germany (Honold and Oberwinkler 1998, 1999) revealed that only combined methods such as mapping fruiting bodies while also extracting and cultivating wooden samples for species identification over several years will reliably detect an increase of species density over succession. Their results could not be achieved by only evaluating fruiting bodies and may explain why we could not find differences between successional stages in fungal diversity. Being strongly weather-dependent, it is likely that the majority of fungal species 
colonizing dead wood did not build fruiting bodies during the survey period. The non-saturating rarified species accumulation curves (Fig. 3.4) suggest that the sampling effort undertaken did not yet cover the whole of the fungal community in the present spruce forest ecosystems.

\section{Relation between faunal and floristic diversity}

Results from this study demonstrate some of the key linkages between floristic and faunal diversity in post-disturbance ecosystems. Herbaceous layers are important to ecosystem functioning (e.g., for nutrient cycling and energy flow; Roberts 2004), and their rapid appearance after disturbances (Halpern 1989) can catalyze biological activity early in succession, resulting in organic matter turnover and mixing with the mineral soil fraction (Lüscher 2002). Additionally, increased diversity of resources (e.g., vascular plants) can support an increased diversity of fauna (e.g., phytophagous consumers; Siemann et al. 1998). Our findings for phytophagous species, whose species density increased with that of the herb layer, support this theory. The density of phytophagous species was, however, influenced more by phytomass (measured as mean cover and height of the herb layer) rather than by plant diversity - perhaps due to the high SLA and primary-secondary production chain of early-seral stands, as described by Campbell and Donato (2014). Another key relationship between flora and fauna involves pollination: the majority of the shrub species present in our study are insectpollinated species (e.g., Lonicera spp., Sambucus spp.), and the positive link between increased shrub diversity and increased diversity of pollinators illustrates a key mechanism that underpins diverse food webs in well-developed early-seral vegetation (i.e., the advanced early-seral stage).

\section{Development and persistence of biodiversity and structural complexity}

This chronosequence spanning the first twenty-five years of succession after bark beetle disturbance shows that various functional groups respond differently to structural changes of the forest. While some groups showed no response to disturbance at all, for others diversity and/or abundance peaked in the initial early-seral phase relative to mature forests then decreased within 25 years, while others continued to increase during the first 25 years of succession. Faunal groups that peaked in species density during the first years were all related to coniferous litter or fresh dead wood and likely benefited from direct inputs from dying trees. Faunal groups that continued increasing for multiple decades included phytophagous and pollinating species that benefited from increasingly abundant and diverse shrub and herb vegetation that developed over time. We note that our sampling effort did not lead to saturation of the rarified species accumulation curves (especially not for fungi), probably due to the generally high gamma diversity in the National Park area (Falkner 1997). Nevertheless, the significantly distinct shapes of the rarefaction curves validate that the higher species densities of fauna (accumulated over all studied functional groups) and flora were not 
biased by unequal numbers of specimens collected. Expanding the study to other species groups of producers (e.g., bryophytes or lichens) and consumers (e.g., birds or small mammals) would have offered a more comprehensive picture of the relationship among forest structure and species density, but these were beyond the resources and scope of the current study.

A principal aim of this study was to evaluate the degree to which the diverse structure and function, for which early-seral forest ecosystems are now recognized (Swanson et al. 2011), may persist beyond the first decade after disturbance. The main hypothesized driver of such persistence is delayed canopy closure of the tree layer, which would allow greater surface light availability, codominance of diverse life forms, and continued structural complexity farther into succession (Donato et al. 2012). Norway spruce forests present an especially interesting test of this theory, because stand re-establishment is driven by an advance regeneration layer of spruce, which is often abundant in these forests and is left intact by bark beetles (e.g., Wild et al. 2014). With this head start, the tree canopy could conceivably close much faster than in other systems or disturbances (e.g., fire) that can be characterized by protracted tree establishment (e.g., Freund et al. 2014). Despite this, we found that several indicators of early-seral structural heterogeneity persisted into the third decade after canopy-removing disturbance. Relative to mature forests, tree cover remained low and spatially clustered (i.e., leaving more gaps), light penetration to the understory remained greater, diversity and abundance of shrubs and herbs had become higher, and dead wood was still abundant. Taken together, these patterns indicate that a structurally complex early-seral period can last for several decades, even in systems driven by advance regeneration. The fact that some faunal groups paralleled these patterns suggests that persistent structural complexity indeed supports related aspects of biodiversity (e.g., Tews et al. 2004, McElhinny et al. 2005).

A remaining question is how much longer these open-canopy conditions may continue into the middle stages of succession and beyond. The stands we studied could represent analogous precocity, such that impending canopy closure will reduce structural heterogeneity for a period (like the mature stands we sampled) until analogous complexity eventually reappears in an old-growth stage following canopy self-thinning; or they could represent homologous precocity if canopy closure is spatially variable and structural complexity is maintained throughout succession (Donato et al. 2012). The fact that stand structure at 25 years was still diverging from, or at least not converging with, mature forest structure suggests the possibility for a more open-canopy pathway that could maintain structural complexity. Nevertheless, our chronosequence was necessarily restricted to the first 25 years following outbreaks, as no unmanaged mid-seral stages were available to sample. Thus it will be essential to survey such middle stages in future studies, especially the relative frequency, timing, and structural influence of tree canopy closure among naturally disturbed and unmanaged sites. 


\section{Management implications}

Where conservation of biodiversity is a prime management objective, the "benign neglect strategy" (Müller et al. 2010) - i.e., no intervention after bark beetle outbreaks - can be an effective approach to maintaining diverse forest structures on a large scale, supporting habitat heterogeneity and subsequently biodiversity. As shown in this study in Berchtesgaden National Park, uncontrolled bark beetle infestations shifted previously human influenced, far-from-nature spruce forests into closerto-nature forest structures within a very short time span. These examples demonstrate the conservation potential of a benign-neglect strategy to transfer anthropogenic forests into a more close-to-nature state (e.g., concerning tree species composition and dead wood resources). Furthermore, strict large-scale nature reserves such as national parks, in which such natural processes are encouraged to operate, can be of high conservation value even in cultural landscapes like Central Europe when the conditions of forests before park establishment are not close-to-nature.

Results from this study suggest there are benefits to management measures that support the structures we quantified, at both stand and landscape scales, as far as economically feasible. Forest management could enhance biodiversity by at least partly retaining (the best undebarked) dead wood to support saproxylic species or by delaying planting of disturbed or logged forest sites. These measures would lengthen regeneration periods for climax tree species to support the variety of species preferring more open habitat conditions, and increase forest stand heterogeneity over time and space. This might be especially applicable for remote mountain forests, where wood production is often not the main objective and management activities can be costly, but heterogeneous and diverse forest stands are a prime objective.

Finally, natural disturbances and succession also may play a role in managed forests. Silvicultural systems should be considered that identify and determine areas in which natural disturbances (e.g., bark beetle, windthrow events) enhance forest functions and benefits (e.g., higher biodiversity) with minimal or manageable effects on neighboring commercial woodlands.

\section{Acknowledgements}

We are grateful to the experts determining the faunistic samples to species level: Alexander Szallies (Coleoptera), Martin Goßner (Heteroptera), Theo Blick (Arachnida, Araneae), Christoph Muster (Arachnida, Opiliones \& Pseudoscorpiones), Jörg Salamon (Collembola), Johannes Voith (Aculeata) and Christian Strätz (Mollusca). We thank Peter Karasch and Andreas Gminder for mapping the wood-decaying fungi and Fritz Eder and many forest students who supported the vegetation mapping and the inventory of stand and regeneration attributes in the field. The project "Forest dynamics following spruce bark beetle calamities in the National Park Berchtesgaden" was funded by 
the Bavarian State Ministry for the Environment and Public Health (StMUG). Finally, the helpful comments of the two anonymous referees on the manuscript are gratefully acknowledged.

\section{References}

Ammer, C., 1996. Konkurrenz um Licht - zur Entwicklung der Naturverjüngung im Bergmischwald. Forstliche Forschungsberichte München 158.

Aubry, S., Magnin, F., Bonnet, V., Preece, R.C., 2005. Multi-scale altitudinal patterns in species richness of land snail communities in south-eastern France. J. Biogeogr. 32: 985-998. http://dx.doi.org/10.1111/j.13652699.2005.01275.x.

Baddeley, A., Turner, R., Rubak, E., 2014. Package "spatstat". Spatial Point Pattern analysis, model-fitting, simulation, tests. Online: http://cran.r-project.org.

Barker, G.M., Mayhill, P.C., 1999. Patterns of diversity and habitat relationships in terrestrial mollusc communities of the Pukeamaru Ecological District, northeastern New Zealand. J. Biogeogr. 26: 215-238. http://dx.doi.org/ 10.1046/j.1365-2699.1999.00267.x.

Bässler, C., Müller, J., Svoboda, M., Lepšová, A., Hahn, C., Holzer, H., Pouska, V., 2012. Diversity of wooddecaying fungi under different disturbance regimes - a case study from spruce mountain forests. Biodivers. Conserv. 21:33-49. http://dx.doi.org/10.1007/s10531-011-0159-0.

Böhme, J., 2001. Phytophage Käfer und ihre Wirtspflanzen in Mitteleuropa - Ein Kompendium. Bioform, Heroldsberg.

Bormann, F.H., Likens, G.E., 1979. Pattern and process in a forested ecosystem. Springer-Verlag, New York, US.

Bouget, C., Duelli, P., 2004. The effects of windthrow on forest insect communities: a literature review. Biol. Conserv. 118 (3): 281-299. http://dx.doi.org/10.1016/j.biocon.2003.09.009.

Braun-Blanquet, J., 1964. Pflanzensoziologie. 3. Ed. Springer, Wien, New York.

Breitenbach, J., Kränzlin, F., 1986. Pilze der Schweiz. Band 2 Nichtblätterpilze. Verlag Mykologia, Luzern.

Campbell, J.L., Donato D.C., 2014. Trait-based approaches to linking vegetation and food webs in early-seral forests of the Pacific Northwest. For. Ecol. Manag. 324: 172-178. http://dx.doi.org/10.1016/j.foreco.2013.11.020.

Clark, P.J., Evans, F.C., 1954. Distance to nearest neighbor as a measure of spatial relationships in populations. Ecology 35: 445-453. http://dx.doi.org/10.2307/1931034.

De Cáceres, M., Jansen, F., 2014. Package "indicspecies". Studying the statistical relationship between species and groups of sites. Online: http://cran.r-project.org.

Donato, D.C., Campbell, J.L., Franklin, J.F., 2012. Multiple successional pathways and precocity in forest development: can some forests be born complex? J. Veg. Sci. 23 (3): 576-584. http://dx.doi.org/10.1111/j.1654-1103.2011.01362.x.

Donato, D.C., Harvey, B.J., Romme, W.H., Simard, M., Turner, M.G., 2013. Bark beetle effects on fuel profiles across a range of stand structures in Douglas-fir forests of Greater Yellowstone. Ecol. Appl. 23(1): 3-20. 
Dufrêne, M., Legendre, P., 1997. Species assemblages and indicator species: the need for a flexible asymmetrical approach. Ecol. Monogr. 67: 345-366. http://dx.doi.org/10.2307/2963459

Ellenberg, H., Leuschner, C., 2010. Vegetation Mitteleuropas mit den Alpen. Ulmer Verlag, Stuttgart.

Eriksson, J., Ryvarden, L., 1987. The Corticiaceae of North Europe. Part 1-8. Fungiflora, Oslo.

Ewald, J., Jehl, H., Braun, L., Lohberger, E., 2011. Die Vegetation des Nationalparks Bayerischer Wald als Ausdruck von Standort und Walddynamik. Tuxenia 31: 9-38.

Falkner, G., 1997. Introduction to the malacological excursion to the Berchtesgaden National Park. Heldia 4 (5): 185-187.

Fischer, A., Fischer, H.S., 2012. Individual-based analysis of tree establishment and forest stand development within 25 years after wind throw. Eur. J. Forest Res. 131 (2): 493-501. http://dx.doi.org/10.1007/s10342-0110524-2.

Fischer, A., Fischer, H.S., Lehnert, U., 2012. Avalanches creating high structural and floristic diversity in mountain mixed forests in the Alps. Biodivers. Conserv. 21 (3): 643-654. http://dx.doi.org/10.1007/s10531011-0204-z.

Fischer, A., Honold, A., Reif, A., Funke, W., Bücking, W., 1998. Die Sturmwurf-Biozönosen in der Startphase der Bestandesentwicklung. In: Fischer (Ed.): Die Entwicklung von Wald-Biozönosen nach Sturmwurf. Ecomed, Landsberg. pp. 357-374.

Franklin, J.F., Spies, T., Van Pelt, R., Carey, A.B., Thornburgh, D.A., 2002. Disturbances and structural development of natural forest ecosystems with silvicultural implications, using Douglas-fir forests as an example. Forest Ecol. Manag. 155: 399-423. http://dx.doi.org/10.1016/S0378-1127(01)00575-8.

Freund, J.A., Franklin, J.F., Larson, A.J., Lutz, J.A., 2014. Multi-decadal establishment for single-cohort Douglasfir forests. Can. J. For. Res. 44 (9): 1068-1078. http://dx.doi.org/10.1139/cjfr-2013-0533

Gotelli, N.J., Colwell, R.K., 2001. Quantifying biodiversity: procedures and pitfalls in the measurement and comparison of species richness. Ecol. Lett. 4 (4) 379-391. http://dx.doi.org/10.1046/j.1461-0248.2001.00230.x.

Halpern, C.B.,1989. Early-successional patterns of forest species: interactions of life history traits and disturbance. Ecology 70(3):704-720. http://dx.doi.org/10.2307/1940221.

Holeska, J., 2003. Relationship between field-layer vegetation and canopy openings in a Carpathian subalpine spruce forest. Plant Ecol. 168: 57-67. http://dx.doi.org/10.1023/A:1024457303815.

Honold, A., Oberwinkler, F., 1998. Pilze im Totholz. In: Fischer (Ed.): Die Entwicklung von Wald-Biozönosen nach Sturmwurf. Ecomed, Landsberg. pp. 214-226.

Honold, A., Oberwinkler, F., 1999. Sukzession saprophytischer und parasitischer Pilze im Fichtentotholz. Ed. v. Spezielle Botanik /Mykologie Universität Tübingen, Botanisches Institut.

Hothorn, T., Bretz, F., Westfal, P., Heiberger, R.M., Schuetzenmeister, A., 2013. R Package 'multcomp'. Simultaneous Inference in General Parametric Models. Online: http://cran.r-project.org.

Hothorn, T., Hornik, K., van de Wiel, M.A., 2014. R Package 'coin'. Conditional Inference Procedures in a Permutation Test Framework. Online: http://cran.r-project.org. 
Huber, C., 2005. Long lasting nitrate leaching after bark beetle attack in the highlands of the Bavarian Forest National Park. J. Environ. Qual. 34 (5): 1772. http://dx.doi.org/10.2134/jeq2004.0210.

Jönsson, A.M., Bärring, L., 2011. Future climate impact on spruce bark beetle life cycle in relation to uncertainties in regional climate model data ensembles. Tellus 63A: $158-173$. http://dx.doi.org/10.1111/j.1600-0870.2010.00479.x.

Jost, L., 2006. Entropy and Diversity. OIKOS 113 (2): 363-375. http://dx.doi.org/10.1111/j.2006.00301299.14714.x.

Kennel, E., 1973. Bayerische Waldinventur 1970/71. Inventurabschnitt 1: Großrauminventur Aufnahme- und Auswertungsverfahren. Forstliche Forschungsberichte München 11.

Kenter, B., Bellmann, H., Spelda, J., Funke, W., 1998. Makrofauna - Zoophage der Streu und der Bodenoberfläche. In: Fischer (Ed.): Die Entwicklung von Wald-Biozönosen nach Sturmwurf. Ecomed, Landsberg. pp. 259-279.

Knott, H., Bernhart, A., Feulner, M., 1988. Geschichte der Salinenwälder von Berchtesgaden. Nationalpark Berchtesgaden. Forschungsbericht 12.

Konnert, V., Siegrist, J., 2000. Waldentwicklung im Nationalpark Berchtesgaden von 1983 bis 1997. Nationalpark Berchtesgaden. Forschungsbericht 43.

Kopf, A., Funke, W., 1998. Xylobionte Arthropoden. In: Fischer (Ed.): Die Entwicklung von Wald-Biozönosen nach Sturmwurf. Ecomed, Landsberg. pp. 282-291.

Köstler, J.N, Mayer, H., 1974. Gutachten über die künftige Behandlung des Waldes im Alpenpark Berchtesgadener Land. München.

Krehan, H., Steyrer, G., 2006. Klimaänderung - Schadorganismen bedrohen unsere Wälder. BFWPraxisinformation 6.

Küffer, N., Senn-Irlet, B., 2005. Influence of forest management on the species richness and composition of wood-inhabiting basidiomycetes in Swiss forests. Biodivers. Conserv. 14 (10): 2419-2435. http://dx.doi.org/10.1007/s10531-004-0151-z.

Kupferschmid Albisetti, A.D., 2003. Succession in a protection forest after Picea abies die-back. Swiss Federal Institute of Technology Zürich. Zürich (Dissertation).

Lehnert, L.W., Bässler, C., Brandl, R., Burton, P.J., Müller, J., 2013. Conservation value of forests attacked by bark beetles: Highest number of indicator species is found in early successional stages. J. Nature Conserv. 21 (2): 97-104. http://dx.doi.org/10.1016/j.jnc.2012.11.003.

Lonsdale, D., Pautasso, M., Holdenrieder, O., 2008. Wood-decaying fungi in the forest: conservation needs and management options. Eur. J. Forest Res. 127 (1): 1-22. http://dx.doi.org/10.1007/s10342-007-0182-6.

Lüscher, P., 2002. Humus dynamics and changes in rooting patterns in windthrow areas. For. Snow Landsc. Res. $77(1 / 2):$ 49-59.

Magurran, A.E., 2004. Measuring biological diversity. Blackwell Publishing, Malden, United States of America. 
McElhinny, C., Gibbons, P., Brack, C., Bauhus, J., 2005. Forest and woodland stand structural complexity: Its definition and measurement. Forest Ecol. Manag. $218 \quad$ (1-3): 1-24. http://dx.doi.org/10.1016/j.foreco.2005.08.034.

Möller, G., 2009. Struktur- und Substratbindung holzbewohnender Insekten, Schwerpunkt Coleoptera - Käfer. Freie Universität Berlin. Berlin (Dissertation).

Müller, J., Strätz, C., Hothorn, T., 2005. Habitat factors for land snails in acid beech forests with a special focus on coarse woody debris. Eur. J. Forest Res. 124: 233-242. http://dx.doi.org/10.1007/s10342-005-0071-9.

Müller, J., Bußler, H., Goßner, M., Gruppe, A., Jarzabek-Müller, A., Preis, M.I, Rettelbach, T., 2007. Forest edges in the mixed-montane zone of the Bavarian Forest National Park - hot spots of biodiversity. Silva Gabreta 13 (2): 121-148.

Müller, J., Bußler, H., Goßner, M., Rettelbach, T., Duelli, P., 2008. The European spruce bark beetle Ips typographus in a national park: from pest to keystone species. Biodivers. Conserv. 17 (12): $2979-3001$. http://dx.doi.org/10.1007/s10531-008-9409-1.

Müller, J., Bässler, C., Strätz, C., Klöcking, B., Brandl, R., 2009. Molluscs and climate warming in a low mountain range national park. Malacologia 51(1): 89-109.

Müller, J., Noss, R.F., Bussler, H., Brandl, R., 2010. Learning from a "benign neglect strategy" in a national park: Response of saproxylic beetles to dead wood accumulation. Biol. Conserv. 143 (11): 2559-2569. http://dx.doi.org/10.1016/j.biocon.2010.06.024.

Mrzljak, J., Wiegleb, G., 2000. Spider colonization of former brown coal mining areas - time or structure dependent? Landscape and Urban Planning 51: 131-146. http://dx.doi.org/10.1016/S0169-2046(00)00104-3.

Nationalpark Berchtesgaden, 2001. Nationalparkplan. Nationalpark Berchtesgaden.

Oberdorfer, E., 2001. Pflanzensoziologische Exkursionsflora für Deutschland und angrenzende Gebiete. Ulmer Verlag, Stuttgart.

Oksanen, J., Blanchet, F.G., Kindt, R., Legendre, P., Minchin, P.R., O'Hara, R. B. et al., 2012. R Package 'vegan'. Community Ecology Package. Online: http://cran.r-project.org.

Regents Instruments Inc, 2003. WinScanopy 2003b for hemispherical image analysis. Québec. Online: http://www.regentinstruments.com.

Rieger, A., Schmidberger, G., Stelz, V., Müller, J., Strätz, C., 2010. Ökologische Analyse der Molluskenfauna im Nationalpark Bayerischer Wald. Waldökologie, Landschaftsforschung und Naturschutz 9: 65-78.

Roberts, M.R., 2004. Response of the herbaceous layer to natural disturbance in North American forests. Can. J. Bot. 82 (9): 1273-1283. http://dx.doi.org/10.1139/B04-091.

Ryvarden, L., Gilbertson, R.L., 1993. European Polypores. Part 1 \& 2. Fungiflora, Oslo.

Saint-Germain, M., Drapeau, P., Buddle, C.M., 2007. Host-use patterns of saproxylic phloeophagous and xylophagous Coleoptera adults and larvae along the decay gradient in standing dead black spruce and aspen. Ecography 30:737-748. http://dx.doi.org/10.1111/j.2007.0906-7590.05080.x 
Salamon, J.-A., Scheu, S., Schaefer, M., 2008. The Collembola community of pure and mixed stands of beech (Fagus sylvatica) and spruce (Picea abies) of different age. Pedobiologia 51 (5-6): 385-396. http://dx.doi.org/10.1016/j.pedobi.2007.10.002.

Sayer, U., Reif, A., 1998. Entwicklung der Vegetation im überregionalen Vergleich. In: Fischer (Ed.): Die Entwicklung von Wald-Biozönosen nach Sturmwurf. Ecomed, Landsberg. pp. 146-168.

Schelhaas, M.-J., Nabuurs, G.-J., Schuck, A., 2003. Natural disturbances in the European forests in the $19^{\text {th }}$ and $20^{\text {th }}$ centuries. Glob. Change Biol. 9: 1620-1633. http://dx.doi.org/10.1046/j.1529-8817.2003.00684.x.

Schmidt, M., Kriebitzsch, W.-U., Ewald, J., 2011. Waldartenlisten der Farn- und Blütenpflanzen, Moose und Flechten Deutschlands. Bundesamt für Naturschutz (BfN). Bonn. BfN-Skripten 299.

Siemann, E., Tilman, D., Haarstad, J., Ritchie, M., 1998. Experimental tests of the dependence of arthropod diversity on plant diversity. Am nat 152 (5): 738-750. http://dx.doi.org/10.1086/286204.

Sippola, A.-L., Similä, M., Mönkkönen, M., Jokimäki, J., 2004. Diversity of polyporous fungi (Polyporaceae) in northern boreal forests: Effects of forest site type and logging intensity. Scand. J. For. Res. 19 (2): $152-163$. http://dx.doi.org/10.1080/02827580410026294.

Sokal, R. M., Rohlf, F. J., 1995. Biometry. Freeman, New York.

Sousa, W.P., 1984. The role of disturbance in natural communities. Ann. Rev. Ecol. Syst. 15: 353-391. http://dx.doi.org/10.1146/annurev.es.15.110184.002033.

Spandau, L., 1988. Angewandte Ökosystemforschung im Nationalpark Berchtesgaden. Nationalpark Berchtesgaden. Forschungsbericht 20.

Spelda, J., Müller, K.H, Funke, W., 1998. Makrofauna - Saprophage der Streu und der Bodenoberfläche. In: Fischer (Ed.): Die Entwicklung von Wald-Biozönosen nach Sturmwurf. Ecomed, Landsberg. pp. 249-258.

Stein, A., Gerstner, K., Kreft, H., 2014. Environmental heterogeneity as a universal driver of species richness across taxa, biomes and spatial scales. Ecol. Lett. 17: 866-880. http://dx.doi.org/10.1111/ele.12277.

Swanson, M. E., Franklin, J. F., Beschta, R. L., Crisafulli, C. M., DellaSalla, D. A., Hutto, R. L. et al., 2011. The forgotten stage of forest succession: early successional ecosystems on forest sites. Front. Ecol. Environ. 9: 117125. http://dx.doi.org/10.1890/090157.

Swanson, M.E., Studevant, N.M., Campbell, J.L., Donato, D.C., 2014. Biological associates of early-seral preforest in the Pacific Northwest. Forest Ecol. Manag. 324: 160-171. http://dx.doi.org/10.1016/j.foreco.2014.03.046.

Tews, J., Brose, U., Grimm, V., Tielbötger, K., Wichmann M.C., Schwager, M., Jeltsch, F., 2004. Animal species diversity driven by habitat heterogeneity/diversity: the importance of keystone structures. J. Biogeogr. 31: 7992.

Ulyshen, M.D., Klooster, W.S., Barrington, W.T., Herms, D.A., 2011. Impacts of emerald ash borer-induced tree mortality on leaf litter arthropods and exotic earthworms. Pedobiologia 54 (5-6): 261-265. http://dx.doi.org/10.1016/j.pedobi.2011.05.001.

Vierling, K.T, Bässler, C., Brandl, R., Vierling, L.A, Weiß, I., Müller, J., 2011. Spinning a laser web: predicting spider distributions using LiDAR. Ecol. Appl. 21 (2): 577-588. http://dx.doi.org/10.1890/09-2155.1. 
Wagner, S., 1998. Calibration of grey values of hemispherical photographs for image analysis. Agric. For. Meteorol. 90:103-117. http://dx.doi.org/10.1016/S0168-1923(97)00073-7.

Wagner, S., 2001. Relative radiance measurements and zenith angle dependent segmentation in hemispherical photography. Agric. For. Meteorol. 107:103-115. http://dx.doi.org/10.1016/S0168-1923(00)00232-X.

Westfall, P., Young, S., 1993. Resampling-based Multiple Testing. John Wiley \& Sons, New York.

Whittaker, R.J., Willis, K.J., Field, R., 2001. Scale and species richness: towards a general hierarchical theory of species diversity. J. Biogeogr. 28: 453-470. http://dx.doi.org/10.1046/j.1365-2699.2001.00563.x.

Wild, J., Kopecký, M., Svoboda, M., Zenáhlíková, J., Edwards-Jonášová, M., Herben, T., 2014. Spatial patterns with memory: tree regeneration after stand-replacing disturbance in Picea abies mountain forests. J. Veg. Sci. 25 (6): 1327-1340. http://dx.doi.org/10.1111/jvs.12189.

Zenner, E.K., 2005. Development of tree size distributions in Douglas-fir forests under differing disturbance regimes. Ecol. Appl. 15 (2): 701-714. http://dx.doi.org/10.1890/04-0150. 


\section{Kapitel 4}

\section{High spatial heterogeneity of early-seral forest ecosystems affects diversity of producers, consumers and decomposers differently}

Winter, M.-B., Bässler, C., Bernhardt-Römermann, M., Krah, F., Schaefer, H., Seibold, S., Müller, J. ${ }^{1}$ Journal of Vegetation Science (eingereicht)

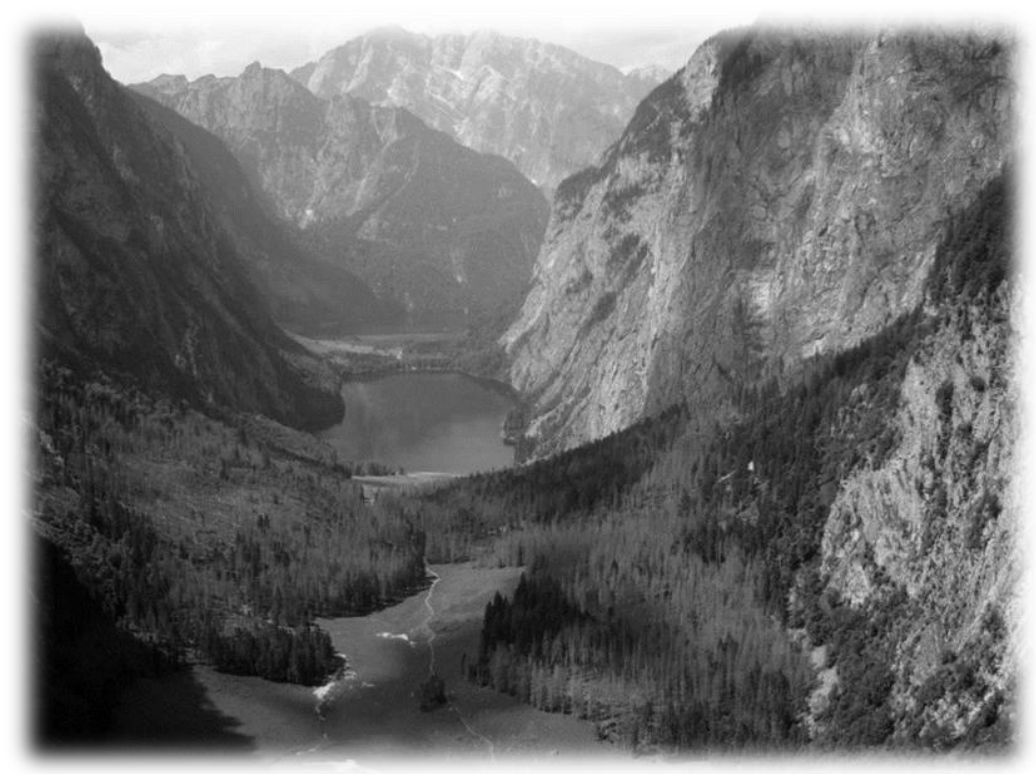

Mosaik verschiedener Entwicklungsstadien und Strukturen auf Landschaftsebene in Fischunkel am Obersee (Foto: M.B. Winter)

1 Maria-Barbara Winter war für die Datenaufnahme, die Auswertung der Daten, die Aufbereitung der Ergebnisse und die Erstellung des Manuskripts verantwortlich. Claus Bässler, Markus Bernhardt-Römermann, Franz-Sebastian Krah, Hanno Schaefer und Sebastian Seibold lieferten die phylogenetischen und funktionellen Informationen der Arten. Jörg Müller betreute Datenauswertung und Manuskripterstellung.

Die Publikation ist hier um deutsche Übersetzungen des Titels und der Über- bzw. Unterschriften von Tabellen und Abbildungen erweitert. 


\section{High spatial heterogeneity of early-seral forest stands affects diversity of producers, consumers and decomposers differently}

Hohe räumliche Heterogenität in frühsukzessionalen Waldbeständen beeinflusst die Vielfalt von Produzenten, Konsumenten und Destruenten unterschiedlich

Maria-Barbara Winter, Claus Bässler, Markus Bernhardt-Römermann, Franz-Sebastian Krah, Hanno Schaefer, Sebastian Seibold \& Jörg Müller

Winter, M.-B. (corresponding author, mbwinter@gmx.de) $)^{1,2}$,

Bässler, C. (claus.baessler@npv-bw.bayern.de) ${ }^{3}$,

Bernhardt-Römermann, M. (markus.bernhardt@uni-jena.de) ${ }^{4}$,

Krah, F.-S. (f.krah@mailbox.org) ${ }^{5}$,

Schaefer, H. (hanno.schaefer@tum.de) ${ }^{5}$,

Seibold, S. (sebastian-seibold@gmx.de) ), $^{3,6}$

Müller, J. (joerg.mueller@npv-bw.bayern.de) ${ }^{3,6}$

${ }^{1}$ Georg-August-Universität Göttingen, Department Silviculture and Forest Ecology of the Temperate Zones, Büsgenweg 1, 37077 Göttingen, Germany.

${ }^{2}$ Forest Research Institute of Baden-Württemberg (FVA), Wonnhaldestraße 4, 79100 Freiburg, Germany;

${ }^{3}$ Bavarian Forest National Park Administration, Freyunger Straße 2, 94481 Grafenau, Germany;

${ }^{4}$ Friedrich-Schiller-Universität Jena, Institute of Ecology, Dornburger Straße 159, 07743 Jena, Germany;

${ }^{5}$ Technische Universität München, Department of Ecology and Ecosystem Management, Plant Biodiversity Research Group, Emil-Ramann Straße 2, 85354 Freising, Germany;

${ }^{6}$ Technische Universität München, Department of Ecology and Ecosystem Management, Terrestrial Ecology Research Group, Hans-Carl-von-Carlowitz-Platz 2, 85354 Freising, Germany 


\section{Abstract}

Questions: Following disturbances, early-seral stages of forests provide a variety of structures and habitats. Whether this variety of structures is a short-term phenomenon or influences forest succession for several decades or even longer is not known. We tested the hypotheses that after spruce dieback induced by bark beetle infestation, a high spatial heterogeneity of stand structures on the landscape scale will persist in advanced early-seral stages and that diversity measures of different species groups and trophic levels will reflect this heterogeneity.

Location: Berchtesgaden National Park, Bavaria, south-eastern Germany

Methods: We assessed alpha and beta diversity of forest stands by analysing stand structure and species composition, phylogenetic diversity and functional diversity of vascular plants, woodinhabiting fungi and saproxylic beetles on a chronosequence of unmanaged, montane/high-montane forests consisting of mature undisturbed spruce stands, stands belonging to an initial early-seral stage and an stands in an advanced early-seral stage.

Results: The stands of the advanced early-seral stage were characterized by a high spatial heterogeneity of structural attributes such as crown cover, regeneration density and spatial distribution of tree bole location. Thereby they resembled the hypothesized complex early-seral forest. During succession, both beta diversity of species composition and phylogenetic beta diversity of saproxylic beetles increased, whereas the species composition of wood-inhabiting fungi changed only slightly and beta diversity decreased. Although alpha diversity of vascular plants was highest in the advanced early-seral stage, heterogenization of stand structures did not lead to significant changes in species composition or beta diversity at the landscape scale. The mosaic of the three successional stages led to gamma diversity values of the study area exceeding those of the single stages for fungi and beetles, but not for plants.

Conclusions: Our findings support the hypothesis of continuing structural heterogeneity in advanced early-seral stages at local and regional scales and indicate that this spatial diversity might shape unmanaged mountain forests - at least at higher altitudes - even longer than the studied two decades. Successional patterns of species groups colonizing the stand habitats did not follow patterns of structural elements uniformly, but correlated differently with single structural attributes.

Keywords Early-seral ecosystems; Natural disturbances; Beta diversity; Structural heterogeneity; Phylogenetic diversity; Functional diversity; Vascular plants; Wood-inhabiting fungi; Saproxylic beetles; Northern Limestone Alps; Berchtesgaden National Park 


\section{Zusammenfassung}

Fragen: Frühsukzessionale Stadien nach natürlichen Störungen können durch eine Vielfalt an verschiedenen Strukturen und Habitaten geprägt sein. Es ist allerdings noch unklar, ob es sich bei dieser Strukturvielfalt um ein temporäres Phänomen handelt, oder ob die Vielfalt mehrere Jahrzehnte überdauern und evtl. noch längerfristig die weitere Walddynamik prägen wird. Nach unserer Hypothese werden auch die Bestandesstrukturen eines fortgeschrittenen frühsukzessionalen Stadiums nach großflächigem Borkenkäferbefall noch durch eine hohe räumliche Heterogenität auf Landschaftsebene geprägt sein, und Diversitätsmaße verschiedener Artengruppen und Trophiestufen werden diese räumliche Strukturheterogenität widerspiegeln.

Untersuchungsgebiet: Nationalpark Berchtesgaden, Bayern, Südost-Deutschland

Methoden: Analyse von Alpha- und Beta-Diversität von räumlicher Bestandesstruktur und Artenzusammensetzung, phylogenetischer und funktioneller Vielfalt von Gefäßpflanzen, totholzbesiedelnden Pilzen und totholzbesiedelnden Käfern anhand einer unechten Zeitreihe (chronosequence) von Fichtenaltbeständen über das beginnende zum fortgeschrittenen frühsukzessionalen Stadium in unbewirtschafteten montanen/hochmontanen Bergwäldern.

Ergebnisse: Das fortgeschrittene frühsukzessionale Stadium war durch eine große räumliche Heterogenität der Strukturmerkmale, wie Überschirmungsgrad, Jungwuchsdichten und räumliche Stammverteilung geprägt und ähnelte damit den in der Hypothese erwarteten komplexen frühsukzessionalen Wäldern. Während die totholzbesiedelnden Käfer vergleichbar, mit einer Änderung und Ausweitung der Artenzusammensetzung und einer zunehmenden Beta-Diversität im Verlauf der Sukzession reagierten, spiegelten die totholzbesiedelnden Pilze die Veränderungen zwar durch eine partielle Verschiebung der Artenzusammensetzung wider, zeigten aber überwiegend abnehmende Beta-Diversitäts-Werte. Die Gefäßpflanzen wiesen die höchste Alpha-Diversität im fortgeschrittenen frühsukzessionalen Stadium auf. Die räumliche Heterogenisierung der Bestandesstrukturen führte jedoch nicht zu signifikanten Veränderungen von Artenzusammensetzung oder Beta-Diversität auf Landschaftsebene. Das räumliche Mosaik der drei Sukzessionsstadien im Untersuchungsgebiet führte für die totholzbesiedelnden Pilze und Käfer zu einer Gamma-Diversität, die jene der einzelnen Sukzessionsstadien übertraf.

Schlussfolgerung: Die Ergebnisse unterstützen die Hypothese einer anhaltenden strukturellen Heterogenität im fortgeschrittenen frühsukzessionalen Stadium auf lokaler und regionaler Ebene und liefern Hinweise, dass diese räumliche Diversität die Entwicklung der unbewirtschafteten Bergwälder - zumindest in höheren Lagen - noch deutlich über die untersuchten zwei Jahrzehnte hinaus prägen 
wird. Die diese Habitate nutzenden Artengruppen spiegelten diese Entwicklung nicht einheitlich wider, sondern wiesen unterschiedlich starke Korrelationen zu den verschieden Strukturelementen auf.

Schlagwörter Frühsukzessionale Ökosysteme; Natürliche Störungen; Beta-Diversität; Strukturelle Heterogenität; Phylogenetische Vielfalt; Funktionelle Vielfalt; Gefäßpflanzen; Totholzbesiedelnde Pilze; Totholzbesiedelnde Käfer; Nördliche Kalkalpen; Nationalpark Berchtesgaden

Nomenclature Wisskirchen \& Haeupler (1998) for vascular plants, MycoBank Database for woodinhabiting fungi (http://www.mycobank.org/, assessed on 20 January 2016), Schmidl \& Bußler (2004) for saproxylic beetles.

Abbreviations NMDS $=$ Non-metric multidimensional scaling, $R=R$ aggregation index of Clark \& Evans (1954).

\section{Introduction}

Early successional stages following large-scale forest disturbances, such as wild fires, insect infestations and storms, have been recently recognized as valuable phases of forest biodiversity (Swanson et al. 2011, 2014, Donato et al. 2012, Beudert et al. 2015). Compared to mature predisturbance stands, early-seral stands considerably differ in biotic and abiotic stand conditions. For example higher solar radiation at ground level, more extreme temperatures and accelerated nutrient fluxes in the soil were reported (Sousa 1984, Roberts 2004, Swanson et al. 2011). The structural diversity of these stands is determined by legacies from the pre-disturbance phase that include dead wood and co-dominating diverse vegetation such as herbs, shrubs and trees (Zenner 2005, Swanson et al. 2011, 2014).

Early-seral stands not only have an increased structural heterogeneity but also show an increased species diversity (Bouget \& Duelli 2004, Campbell \& Donato 2014, Swanson 2014, Beudert et al. 2015). The latter finding may at least be partly explained by the habitat heterogeneity hypothesis, which states that habitat heterogeneity is positively correlated with species diversity (e.g. Tews et al. 2004, McElhinny et al. 2005, Stein et al. 2014). The greater diversity in early-seral stands compared to that of mature pre-disturbed forest stands has most often been observed as an increase in species density or species richness at the alpha-diversity level, which indicates improved conditions for the surveyed species on a temporal scale (Bouget \& Duelli 2004, Müller et al. 2008, Campbell \& Donato 2014). In our earlier investigation of the 20 -year development of various functional groups of flora, fauna and fungi after a bark beetle-induced spruce dieback, we found a significant increase in species density at the alpha-diversity level over time - especially of taxa dependent on light, nutrients or 
dead wood (Winter et al. 2015a). At the same time, structural attributes and regeneration densities varied greatly among plots of the same successional stage (Winter et al. 2015b), as did diversity attributes (Winter et al. 2015a). This within-stage variation, as a measure of beta diversity, i.e. spatial heterogeneity on a landscape scale, is regarded as a key attribute that drives further regional successional patterns (Donato et al. 2012).

Donato et al. (2012) hypothesized that the rate and pattern of tree canopy closure following standreplacing disturbances determine the direction of further forest succession: (i) dense and synchronous tree establishment truncates the diverse early-seral phase quickly (conventional pathway), (ii) sparse or protracted tree establishment allows structurally diverse conditions to develop (analogous precocity pathway due to certain structural similarities to old forests), and (iii) lack of tree canopy closure causes this diversity to persist throughout succession to the old-growth stage (homologous precocity pathway). An understanding of successional patterns and possible alternative pathways that determine the occurrence and longevity of an early-seral phase after a natural forest disturbance is crucial for conservation management of naturally disturbed forests. The capacity of species to survive in communities within a given environment is defined to a large extent by traits inherited through the evolution of lineages (Graham et al. 2009, Ndiribe et al. 2014). The analysis of functional and phylogenetic structures of species assemblages thus provides a method to test the diversity of structural attributes used by the species groups studied (Cadotte et al. 2011).

This study focuses on the change in beta diversity of vascular plants, wood-inhabiting fungi and saproxylic beetles after canopy opening caused by bark beetle outbreaks in the alpine Berchtesgaden National Park, Germany. We assessed stand structure, species composition, phylogenetic and functional diversity of species assemblages in mature spruce forests (no or only endemic beetle activity), initial early-seral vegetation ( 3 years after severe bark beetle outbreak) and advanced early-seral vegetation ( 20 years after severe bark beetle outbreak) in unmanaged montane and high montane forests. As members of different trophic levels the three investigated taxonomic groups are expected to react variously on the stand-replacing disturbance: while vascular plants as primary producers respond mainly on the evolved gap conditions with e.g., increased light availability (Ammer 1996, Lehnert et al. 2013, Winter et al. 2015a), saproxylic fungi as decomposers and saproxylic beetles who predominantly act as consumers benefit primarily of the dead wood legacies of the preceding spruce stand (Saint-Germain et al. 2007, Müller et al. 2008, 2010, Bässler et al. 2012, Winter et al. 2015a). The analysis of the selected species groups, driving mayor ecosystem functions, together with the stand structural attributes is assumed to enable a comprehensive insight into the ecology of early-seral stages and successional pathways. We expected that the bark beetleinduced spruce dieback would lead to heterogenization of spatial stand structure on local and 
landscape scale and that intensified competition would increase beta diversity of species composition as well as phylogenetic and functional characteristics in the initial early-seral stage. We expected that this increased beta diversity of structure and species would still persist in an advanced early-seral stage (Fig. 4.1). Such a pattern could indicate a continuity of spatial diversity in the advanced early-seral stage on a landscape scale, which would support the homologous precocity pathway hypothesized by Donato et al. (2012) and would point to the importance of this stage for maintaining species biodiversity in forest ecosystems. Additionally we expected a high species gamma diversity when combining the three successional stages, representing a heterogeneous mosaic of different structures in the study area.

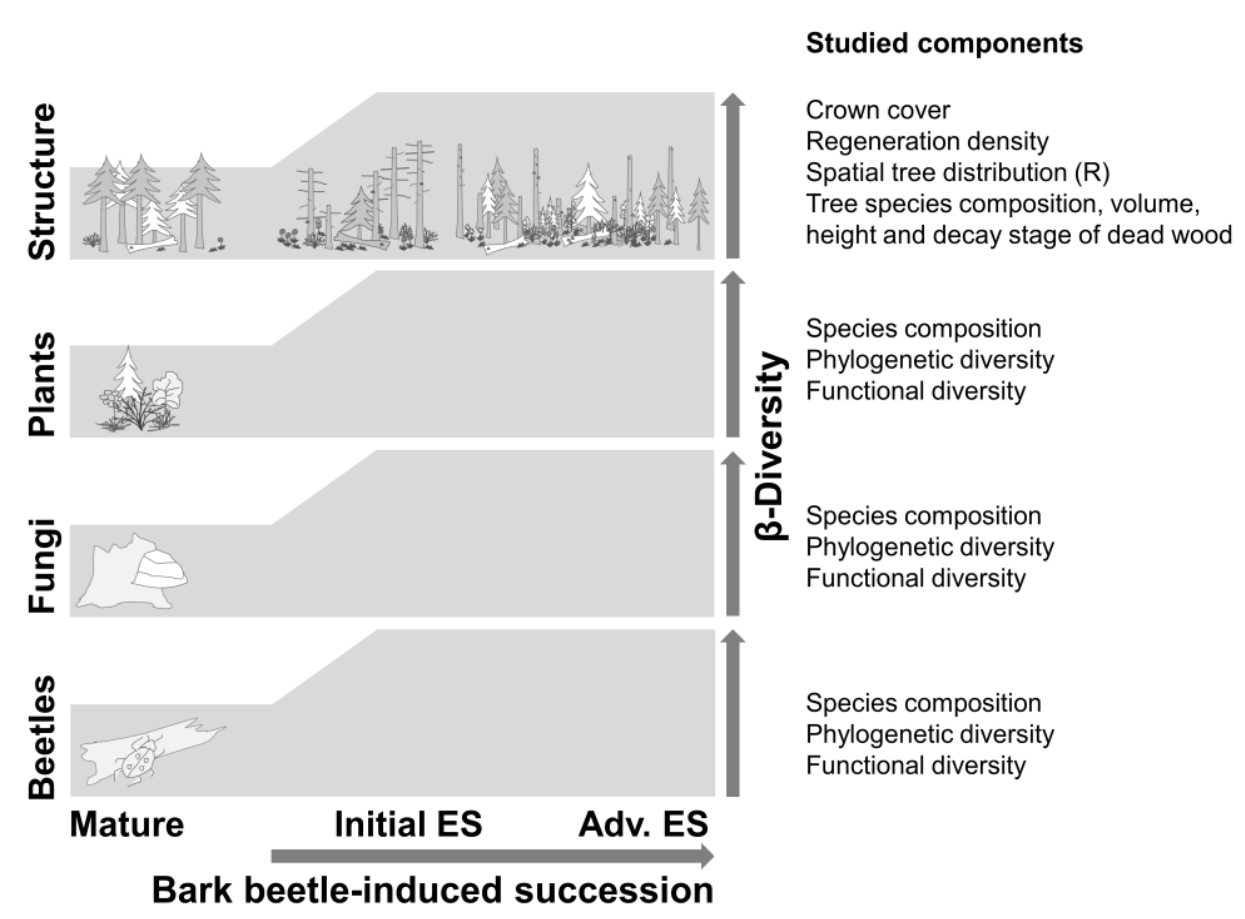

Fig. 4.1 Hypothesized changes in beta diversity of stand structural elements, vascular plants, wood-inhabiting fungi and saproxylic beetles at three stages of bark beetle-induced forest succession. Mature: mature spruce forest, Initial ES: initial early-seral stage, Adv. ES: advanced early-seral stage. Beta diversity is defined in this study as heterogeneity (calculated as mean pairwise distance) among plots of the same successional stage on landscape scale and can therefore be a measure of structures as well as of species.

Abb. 4.1 Erwartete Veränderungen der Beta-Diversität von Bestandesstrukturen, Gefäßpflanzen und totholzbesiedelnden Pilzen und totholzbesiedelnden Käfern im Verlauf der von Borkenkäferbefall beeinflussten Waldsukzession. Mature: Fichtenaltbestand, Initial ES: beginnende Sukzession, Adv. ES: fortschreitende Sukzession. Beta-Diversität wird in dieser Studie als Heterogenität zwischen den Probeflächen eines Sukzessionsstadiums auf Landschaftsebene verstanden und als mittlere paarweise Distanz berechnet. Es ist damit sowohl ein $M a ß$ für die räumliche Heterogenität von Strukturen als auch von Artengemeinschaften. 


\section{Materials and methods}

\section{Study area}

Berchtesgaden National Park, founded in 1978, is located in south-eastern Germany in the Northern Limestone Alps and covers an area of 20800 ha (Fig. 4.2) with an altitudinal gradient from 603 to $2713 \mathrm{~m}$ a.s.l. (Nationalpark Berchtesgaden 2001). The mean annual temperature ranges from +7 to $-2{ }^{\circ} \mathrm{C}$. Annual precipitation values vary between 1500 and $2600 \mathrm{~mm}$ (Spandau 1988). The natural forest type in the mid-elevation zones of the region is mixed-montane European beech (Fagus sylvatica) forests with Norway spruce (Picea abies) and silver fir (Abies alba, Köstler \& Mayer 1974). Historically, centuries of high demand for timber from the salt mining industry greatly altered the natural tree species composition in all accessible parts of these forests (von Pechmann 1932). As Norway spruce ensured better timber floating and burning conditions, the alterations favoured pure Norway spruce stands (Knott et al. 1988; Konnert \& Siegrist 2000). Following the winter storms in 1990, about 100 ha of spruce stands in the park were affected by bark beetle (primarily Ips typographus). This led to nearly $100 \%$ mortality in patches of up to 1 ha in size (Winter et al. 2015b). The outbreak ceased naturally at the end of the 1990s (Nationalpark Berchtesgaden 2001). Unlike the preceding events, the winter storms Kyrill in 2007 and Emma in 2008 primarily disturbed the unmanaged zone. The storms initiated bark beetle infestation of approximately 400 ha of spruce forest, which lasted until 2014 (Winter et al. 2015b).

\section{Study design}

For this study, we sampled three different stages of forest succession (Fig. 4.1), which represent a chronosequence of unmanaged forests that characterize natural dynamics following spruce bark beetle attack. The three stages are defined according to Winter et al. (2015a): undisturbed secondary spruce stands that are 80-250 years old and potentially susceptible to bark beetle infestation (mature stage), stands affected by bark beetles within the last five years (initial early-seral stage) and stands infested 17-25 years ago in the 1990s (advanced early-seral stage). Each stage was sampled on six different plots in two altitudinal zones (montane: 700-1200 m a.s.l.; high montane: 1200-$1400 \mathrm{~m}$ a.s.l.) on both south- and north-facing slopes. The study comprised a total of 72 plots (3 stages $\times 2$ zones $\times 2$ aspects $\times 6$ replicate plots).

In the initial and advanced early-seral stage sites, circular study plots ( $0.05 \mathrm{ha})$ were located in the centre of forest gaps resulting from bark beetle attack. In mature stage spruce stands, study plots (0.05 ha) were located on grid points of the national park forest inventory grid (Konnert \& Siegrist 2000) in areas dominated by spruce and closest to selected forest gaps resulting from bark beetle 
attack (for details, see Winter et al. 2015a). The study plots were distributed over the entire sprucedominated area of the national park (Fig 4.2). The plots of each triple of the three different successional stages are located close to each other, and there are no significant differences in spatial distribution among the three successional stages. The mean distances ( \pm twofold standard error)

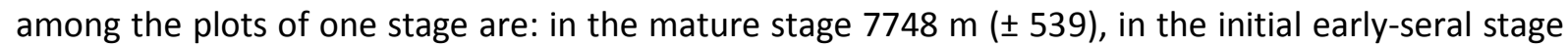
$7648 \mathrm{~m}( \pm 576)$ and in the advanced early-seral stage $7292 \mathrm{~m}( \pm 539)$.

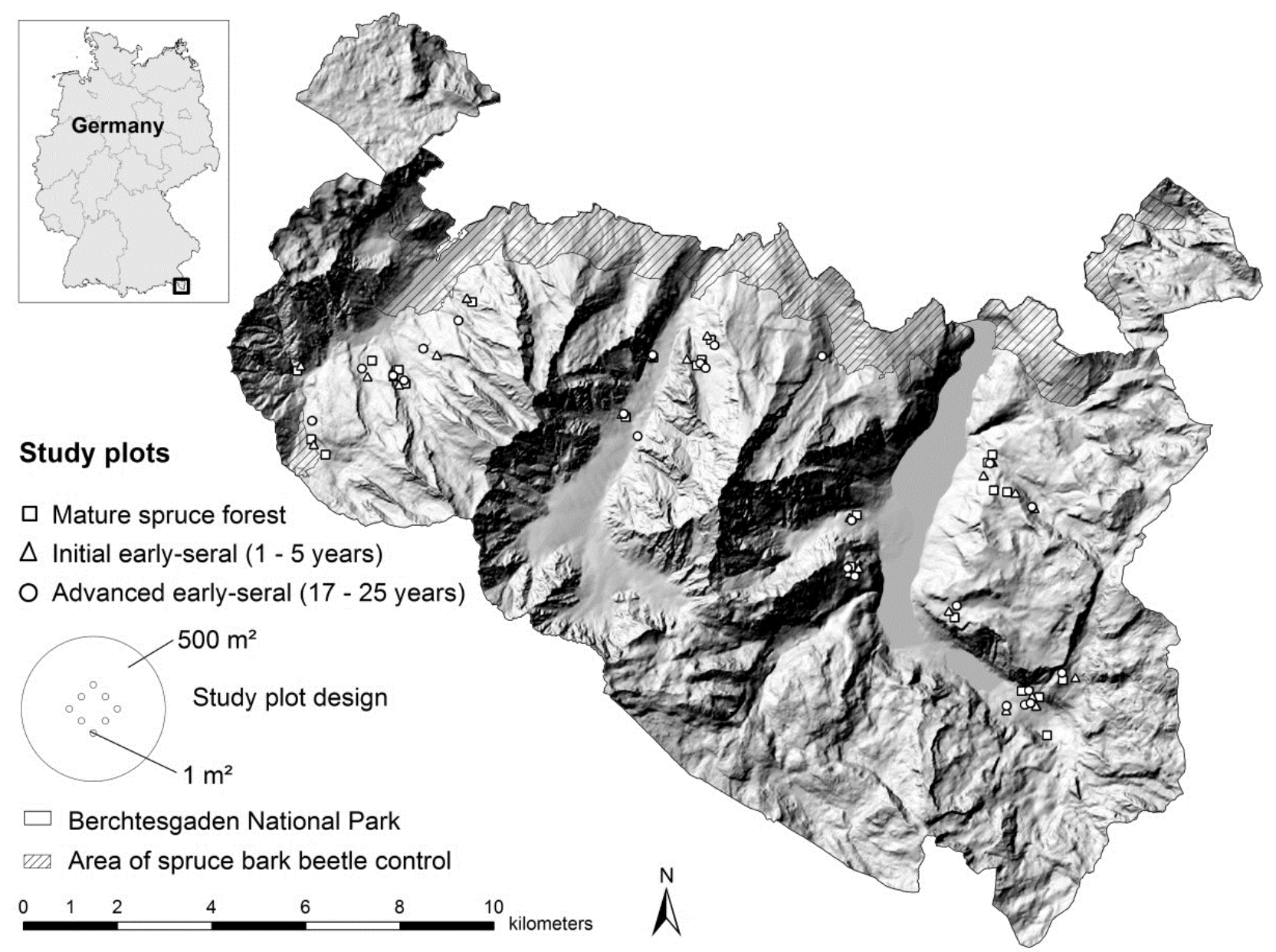

Fig. 4.2 Topographical map of Berchtesgaden National Park showing the position of the 72 study plots in the spruce-dominated areas of the park. The map insert in the upper left indicates the location of the national park in south-eastern Germany. The study plot design illustrates the surveying method with main plots of 0.05 ha and eight subplots of $1 \mathrm{~m}^{2}$.

Abb. 4.2 Topographische Karte des Nationalparks Berchtesgaden mit der Lage der 72 Probeflächen in den fichtendominierten Gebieten des Parks. Die kleine Karte gibt die Lage des Nationalparks an der südöstlichen Grenze Deutschlands an. Die Graphik des Probeflächendesigns verdeutlicht die Aufnahmemethodik mit 0.05 ha Gesamtprobefläche und acht $1 \mathrm{~m}^{2}$ Kleinkreisen. 


\section{Data collection}

Sampling took place during the vegetation periods in 2012 and 2013 (Winter et al. 2015a). On 36 of the 72 study plots ( 3 replicate plots per combination of stage, zone and aspect), structural attributes, vascular plants, wood-inhabiting fungi and saproxylic beetles were recorded. On the other 36 plots, only structural attributes and vascular plants were recorded. Stand structural attributes were measured following standard forest measurement procedures (Konnert \& Siegrist 2000) and included crown cover within the plot, tree bole location, diameter at breast height, and height of all trees taller than $2 \mathrm{~m}$ on the study plots; regeneration parameters were measured on subplots (for details, see Winter et al. 2015b).

Vascular plants were mapped once on each of the 72 study plots in May-July 2012 or May-July 2013 following the method of Braun-Blanquet (1964). Each 0.05 ha study plot was mapped separately from its eight associated subplots (Fig. 4.2, small graph). Wood-inhabiting fungi were sampled on 36 study plots during a three-week period in August and September 2013. The macroscopic survey of fruiting bodies was standardized per plot to 90 min. Dead-wood substrates (tree, snag, log, stump, branches) were sampled according to their frequency on a plot, with as many objects as possible within the time frame. Fungi were identified to the species level in the field or in the laboratory (Winter et al. 2015a). Beetles were sampled on the same 36 study plots during the growing season in 2012 (May-September) using two pitfall traps and one flight-interception trap per plot (for details, see Winter et al. 2015a). The traps were emptied monthly during the growing season, and beetle specimens were determined to the species level by an external specialist. Only saproxylic beetles, i.e. directly or indirectly dependent on dead wood, were included in this analysis.

\section{Community phylogenies and functional traits}

Saproxylic beetle phylogeny was according to Seibold et al. (2015), who modified the comprehensive phylogeny of Hunt et al. (2007) to include all relevant Bavarian taxa. The community phylogenies of plants and fungi of the study sites were estimated as explained in Appendix 4.S1. The three community phylogenies are shown in Appendices 4.S8-4.S10. In order to homogenize the phylogenetic information available, the calculated distance matrices of the trees were standardized to a range of 0 to 1 prior to further calculations.

We compiled published information on species ecological traits known to represent a broad spectrum of the fundamental processes persistence and regeneration, and determined the development of each species group. Appendices 4.S2 and 4.S4 give an overview of all traits included in the analysis, their attribution to the processes persistence and regeneration, and their origin. 


\section{Statistical analyses}

All statistical calculations were performed using R 3.1.0 (R Core Team 2013). To assess horizontal stand structure, the aggregation index $R$ of Clark \& Evans (1954) was calculated for the spatial distribution of live trees within each plot, using data of tree bole location and the cumulative distribution function method within the clarkevans function to correct for edge effects (package spatstat). Values of $R>1$ indicate a regular/dispersed distribution relative to random, while values of $R<1$ suggest clustering of the trees on the plot relative to random. Regeneration density is defined here as number of trees between 0.5 and $2.0 \mathrm{~m}$ in height per hectare (for details, see Winter et al. 2015b). Beta diversity is defined in this study as heterogeneity (calculated as mean pairwise distance) among plots of the same successional stage on landscape scale and can therefore be a measure of structures as well as of species. Beta diversity of structural attributes was computed with Euclidian distance.

In order to use the same diversity measure for trap data (saproxylic beetles) and mapping data (vascular plants and wood-inhabiting fungi), we used species densities, i.e. the number of species per specified collection unit (here: study plot; Magurran 2004), as a measure of alpha diversity. In a parallel analysis, we estimated the extrapolated species densities of the single successional stages and, as a measure of gamma diversity, combined for the species pool of all three stages using the function specpool with incidences in sample sites and the following estimators: Chao (Chao 1987), Jackknife and Bootstrap (Smith \& van Belle 1984; package vegan).

To compare species composition of the three successional stages, samples were ordered by dissimilarity using non-metric multidimensional scaling (NMDS, Legendre \& Legendre 1998) with function metaMDS (package vegan). In order to approach normal distribution of data, cover values of vascular plants were square-root transformed and abundances of fungi and beetles were log transformed prior to analysis (Leyer \& Wesche 2007). The NMDS, based on rank orders, was calculated with Bray-Curtis distances (Legendre \& Legendre 1998), which ordered species and sites in a two-dimensional scale. The relative proportion of beta diversity indicated by species composition was calculated with additive diversity partitioning using adipart function, incidence species data and 10000 permutations (package vegan). To quantify the impact of known environmental conditions on the species composition, the unconstrained NMDS ordination graph was overlaid with environmental variables. For this purpose, the aspect was transformed from $360^{\circ}$-values to ecologically more meaningful values ranging from 0 (south-south-west) to 2 (north-north-east) following the method of Beers et al. (1966). Even though there is a clear link among the species composition of vascular plants and the abundance-weighted mean indicator values of Ellenberg \& Leuschner (2010) of the plant species present, these values were included as overlaid environmental variables to give an 
impression of unmeasured site conditions. To explore relationships among all explanatory variables, a correlation matrix was calculated using non-parametric Spearman rank correlation coefficients. Variables that were highly correlated with each other $(r>0.6)$ were eliminated from further analysis to avoid multicollinearity. The remaining environmental variables were fitted onto the NMDS ordination with maximum correlation to the NMDS pattern using the envfit function (package vegan). A permutation test (with 10000 repetitions) was calculated to test the hypothesis of a relationship among environmental variables and species composition (Table 4.1).

Phylogenetic and functional diversity at the alpha-diversity level was calculated as standardized effect size of the mean pairwise distance of the species within one assemblage with the function ses.mpd (package picante), using abundance data for functional diversity. For phylogenetic diversity, incidence data were used so that the genetic information of rare species would not be underestimated. The standardized effect sizes describe the difference between the distances in the observed communities versus null communities generated with 999 randomizations of the tip labels. Values close to 0 show random dispersion, values $<0$ point toward clustering, and values $>0$ indicate overdispersion within assemblages (Pausas \& Verdú 2010). Phylogenetic distances were calculated with the function cophenetic.phylo (package ape), which computes the pairwise distances between the pairs of tips from a phylogenetic tree using its branch lengths. Beta diversity of single numeric traits was computed with Euclidian distance; single categorical traits and overall functional diversity were computed with Gower distances as the latter enables the joint consideration of numeric and categorical variables (package $F D$ ). Phylogenetic and functional beta diversities among plots of the same successional stage were calculated with function comdist (package picante).

The assumption of independence among the three succession stages was assessed by means of resampling-based multiple testing for all calculations of alpha diversity and beta diversity (Westfall \& Young 1993). The $p$-values obtained by this procedure were adjusted for multiple comparisons utilizing a step-down max-T approach (Algorithm 2.8 in Westfall \& Young 1993). For each response variable, a post-hoc test (Tukey all-pair comparisons) was also applied to assess the differences of the rank-transformed response variables between each pair of categories (packages multcomp and coin). The level of significance for all statistical inferences was defined as $\alpha \leq 0.05$. 


\section{Results}

\section{Structural heterogeneity}

On the alpha-diversity level, mean values of crown cover, horizontal stand heterogeneity $(R)$ and dead-wood volume differed significantly between the mature stage and the initial- and advanced early-seral stages (Table 4.2). Even though regeneration density was significantly higher in the advanced early-seral stage than in the two preceding stages, crown cover remained lower than that of the mature stage. The spatial distribution of trees on the plots was more heterogeneous in the initial and advanced early-seral stands. In all three successional stages, trees were spatially clustered $(R<1)$, but the clustering was significantly more evident in the two early-seral stages than in the mature stage. Stands of the initial early-seral stage were characterized by higher and less-decayed dead wood than either of the other successional stages. The number of tree species of dead wood did not significantly differ among the successional stages (Table 4.2).

We analysed the variation of stand structural attributes on the landscape scale by investigating beta diversity of structural attributes among plots of the same successional stage. Highest values were obtained for crown cover and regeneration density in the advanced early-seral stage. Crown cover and regeneration density were not correlated (Pearson $r=0.11, p=0.35$ ). The beta diversity values for spatial distribution of trees and dead-wood volume were higher for both post-successional stages than for the mature stage. The beta diversity of dead-wood species composition and decay stages was highest for the mature stage, that of dead-wood diameter was highest in the mature stage and advanced early-seral stage, and that of dead-wood height was highest in the mature stage and initial early-seral stage (Table 4.2).

\section{Species density}

We found 327 vascular plant species, 242 wood-inhabiting fungal species and 137 saproxylic beetle species (Appendices 4.S5-4.S7). The species density of vascular plants was higher on the $1 \mathrm{~m}^{2}$ subplots of the advanced early-seral stage than on subplots of the mature stage and initial early-seral stage; the same trend was observed at the plot level. The mean species densities of wood-inhabiting fungi were not significantly different among the successional stages. The species density of saproxylic beetles was highest during the initial early-seral stage (Table 4.2). 


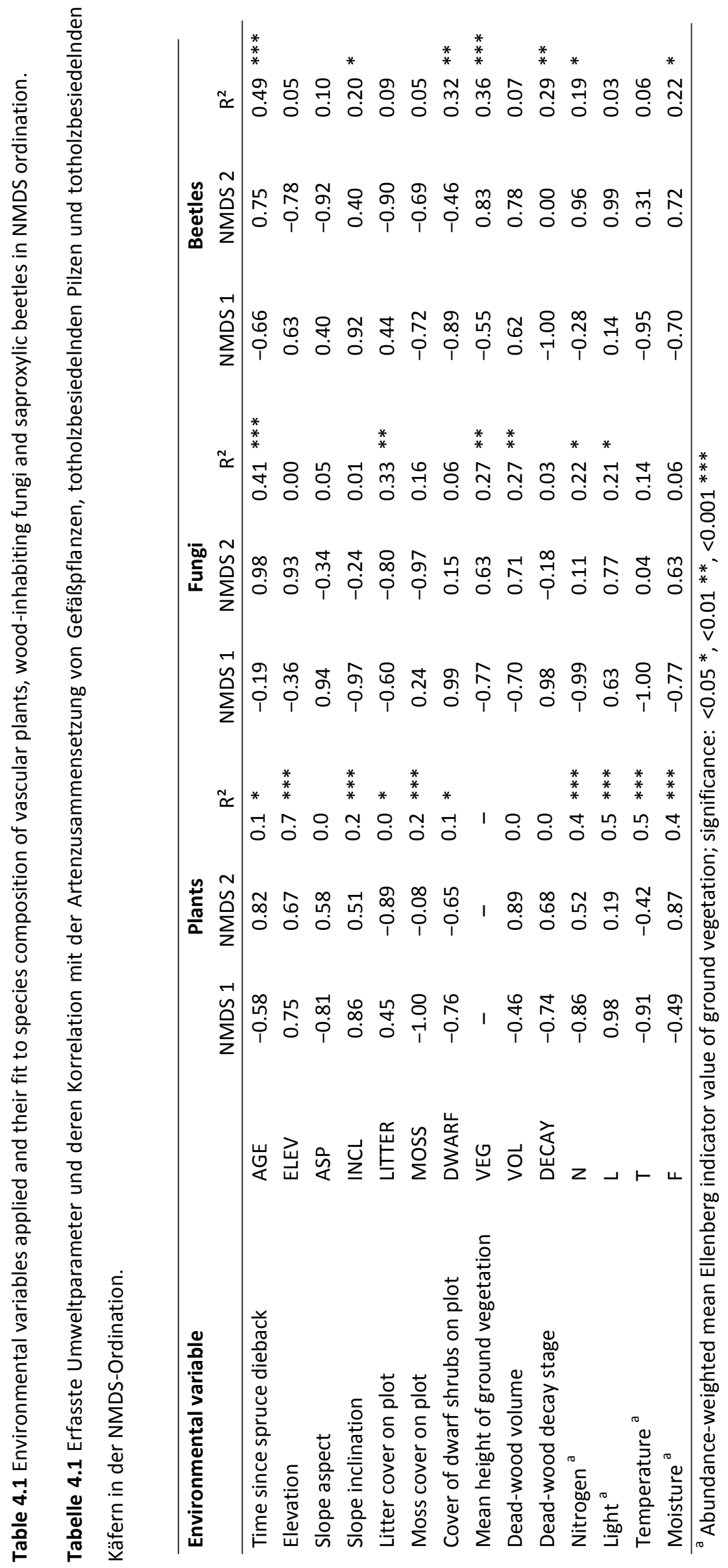




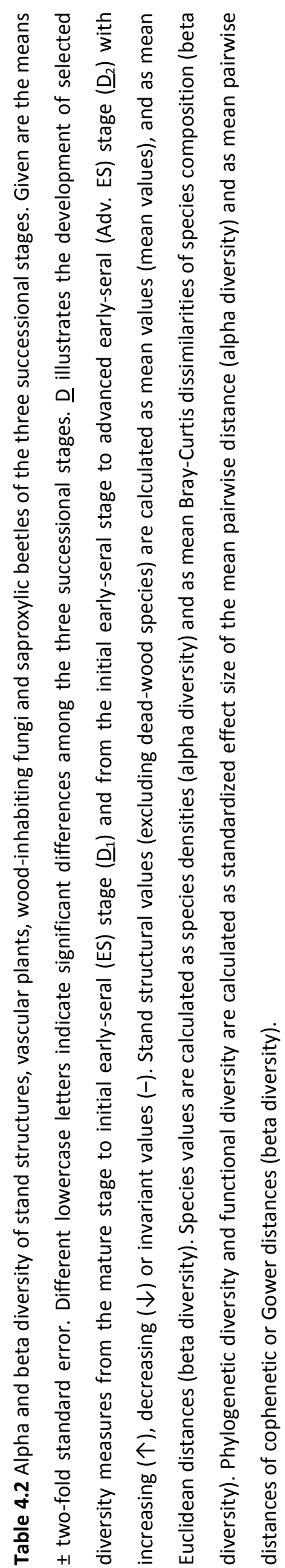

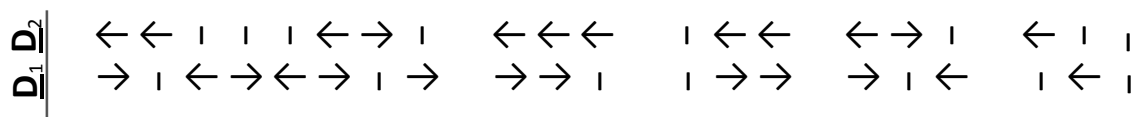

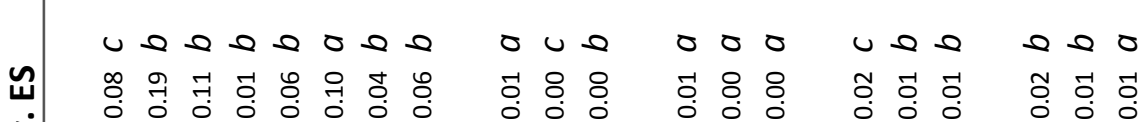

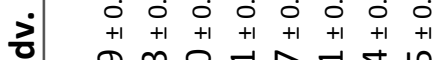

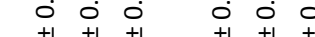

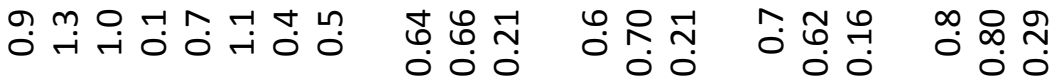

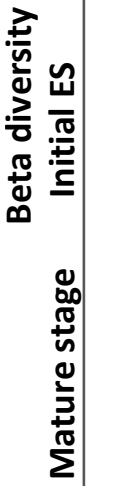

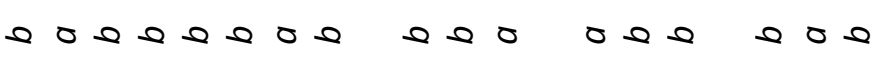

$$
\begin{aligned}
& \text { กำ ఇ }
\end{aligned}
$$

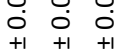

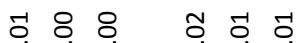

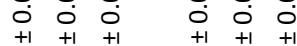

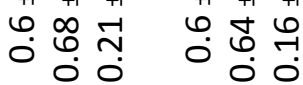

$$
\begin{aligned}
& \text { m்̃ } \\
& \begin{array}{lllllllllll}
0 & 0 & 0 & 0 & 0 & 0 & 0 & 0 & 0 & 0 & 0
\end{array}
\end{aligned}
$$

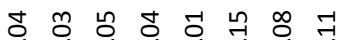

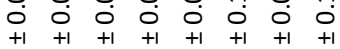

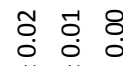

$$
\begin{aligned}
& \begin{array}{lllllll}
0 & 0 & 0 & 0 & 0
\end{array}
\end{aligned}
$$

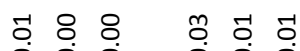

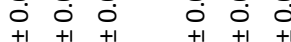

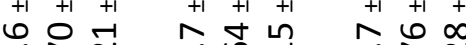

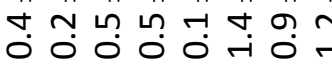

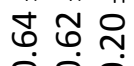

$$
\begin{aligned}
& \text { 品只 } \\
& 000 \\
& 08 \\
& \begin{array}{lll}
0+1 & 1 & 1 \\
+1 & +1 & +1 \\
+1 & 0 & 0
\end{array} \\
& \text { ก. } \\
& \text { ०ं } \\
& 000
\end{aligned}
$$

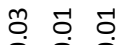

$$
\begin{aligned}
& \leftarrow \stackrel{\infty}{\sim} \\
& 000 \\
& \text { 0 } \quad 1 \leftarrow \begin{array}{llll}
1 & 1 & 1 & 1
\end{array} \rightarrow \leftarrow \leftarrow \text {, } \leftarrow \text {, } \leftarrow \\
& \text { Dी } \rightarrow 1 \rightarrow 1 \leftarrow 1 \leftarrow \rightarrow 1 \rightarrow 1 \\
& \text { Q e } 0 \text { 0 } 00 \\
& \text { Q } 00 \\
& 00 \\
& \begin{array}{ccc}
\hat{0} & \multicolumn{1}{c}{c} & 0 \\
0 & -1 \\
+1 & 0 & 0 \\
+1 & 0
\end{array} \\
& \text { ம் } \stackrel{\infty}{\sim}
\end{aligned}
$$

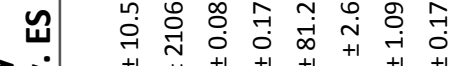

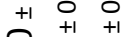

$$
\begin{aligned}
& +100 \\
& \begin{array}{llll}
+1 & +1 & +1 & +1
\end{array}
\end{aligned}
$$

壱

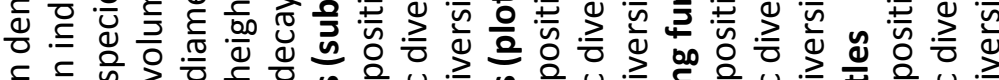

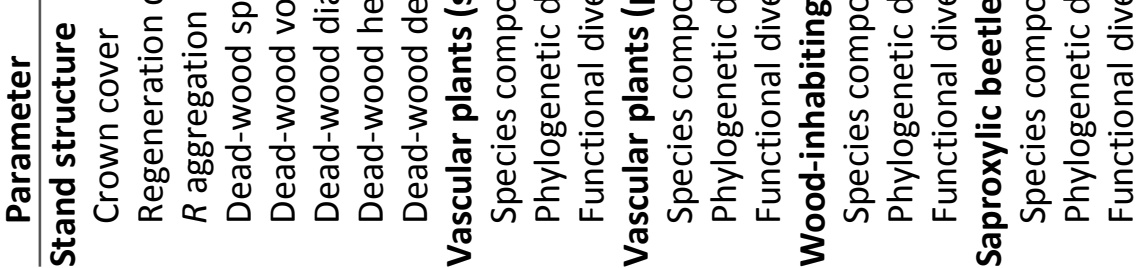


Tabelle 4.2 Alpha- und Beta-Diversität der Bestandesstrukturen, Gefäßpflanzen, totholzbesiedelnden Pilze und totholzbesiedelnden Käfer in den drei Sukzessionsstadien. Angegeben sind Mittelwert \pm zweifacher Standardfehler. Verschiedene Kleinbuchstaben kennzeichnen signifikante Unterschiede zwischen den drei Sukzessionsstadien. $\underline{D}$ verdeutlicht die Entwicklung der Struktur- und Diversitätsattribute von den Fichtenaltbeständen (Mature) zum beginnenden frühsukzessionalen Stadium (Initial ES; $\underline{D}_{1}$ ) und vom beginnenden frühsukzessionalen Stadium zum fortgeschrittenen frühsukzessionalen Stadium $\left(A d v . E S ; \underline{D}_{2}\right)$ mit zunehmenden $(\uparrow)$, abnehmenden $(\downarrow)$ oder gleichbleibenden $(-)$ Werten. Von Bestandesstrukturen (excl. Totholz-Arten) sind Mittelwerte (mean values) und mittlere euklidische Distanzen (beta diversity), von Arten sind Artendichten (alpha diversity) und mittlere Bray-Curtis Unähnlichkeiten der Artenzusammensetzung (beta diversity) und von phylogenetischer und funktioneller Vielfalt sind standardisierte Effektgrößen der mittleren paarweisen Distanzen (alpha diversity) und mittlere paarweise cophenetic- oder Gower-Distanzen (beta diversity) angegeben.

\section{Species composition}

Stress values of 0.25 to 0.22 showed an adequate fit of the NMDS ordination procedures based on rank abundances of the three species groups on the two-dimensional scale (Fig. 4.3). The ordinations did not explicitly differentiate the species compositions among the three successional stages, as the ellipses depicting the standard deviation of the averages of study plots of one successional stage partly overlapped. The species overlap was largest for vascular plants (Fig. 4.3a); fungi and beetles showed larger differentiations, with the highest beta diversity of wood-inhabiting fungi in the mature stage (Fig. $4.3 \mathrm{~d}$ ) and the highest beta diversity of saproxylic beetles in the advanced early-seral stage (Fig. 4.3g). While the co-variables dead-wood volume, dead-wood decay stage, height of ground vegetation, cover of dwarf shrubs, and age since spruce dieback showed the highest degree of correlation to species composition of fungi (Fig. 4.3f) and beetles (Fig. 4.3i) in the ordination, plant species were ordinated along a thermal gradient, as illustrated by clustering of the study plots of elevation and aspect class and by the high loading of the co-variables Ellenberg temperature indicator value and elevation (Fig. 4.3c). Additive diversity partitioning showed that $77-90 \%$ of the observed gamma diversity of the species groups could be attributed to beta diversity among plots (Fig 4.3a, d, g). The extrapolation of species densities indicated a high number of unseen species of wood-inhabiting fungi and saproxylic beetles in our study. The combined analysis of species assemblages of all three successional stages as extrapolated species densities lead to overall species (gamma) diversity, exceeding those of the single stages for wood-inhabiting fungi and saproxylic beetles, but not for vascular plants (Appendix 4.S11). 


\section{Phylogenetic diversity}

As indicated by standardized effect sizes of phylogenetic diversity larger zero, plant assemblages were overdispersed, while wood-decaying fungi and saproxylic beetle assemblages did not significantly differ from a random distribution, although the latter assemblages tended towards clustering (Table 4.2). The phylogenetic diversity of none of the studied species groups differed among the three successional stages at the plot level. The advanced early-seral stage showed highest values of phylogenetic beta diversity (measured as mean pairwise distances) for plants on subplots. Plants on main plots showed high values of phylogenetic beta diversity both, in the advanced earlyseral stage and in the mature stage. For saproxylic beetles, the phylogenetic beta diversity was higher in both post-successional stages than in the mature stage. Only wood-inhabiting fungi displayed the lowest heterogeneity of phylogenetic information on the landscape scale in the advanced early-seral stage (Table 4.2).

\section{Functional diversity}

The standardized effect sizes of functional diversity did not differ from random for plants and woodinhabiting fungi, but were negative for saproxylic beetles, i.e., clustered. For plants, the standardized effect size of functional diversity was higher in the advanced early-seral stage than in the initial earlyseral stage; for wood-inhabiting fungi and saproxylic beetles, standardized effect size of functional diversity did not differ among stages (Table 4.2). Beta diversity of beetles did not significantly differ among the successional stages. For plants the mature stage and the advanced early-seral stage displayed the highest heterogeneity, for fungi the initial and the advanced early-seral stage, displayed the highest heterogeneity of overall functional trait information on the landscape scale (Table 4.2). Results and interpretation of single functional traits of species groups are given in Appendices 4.53 and 4.S4. 
Plants
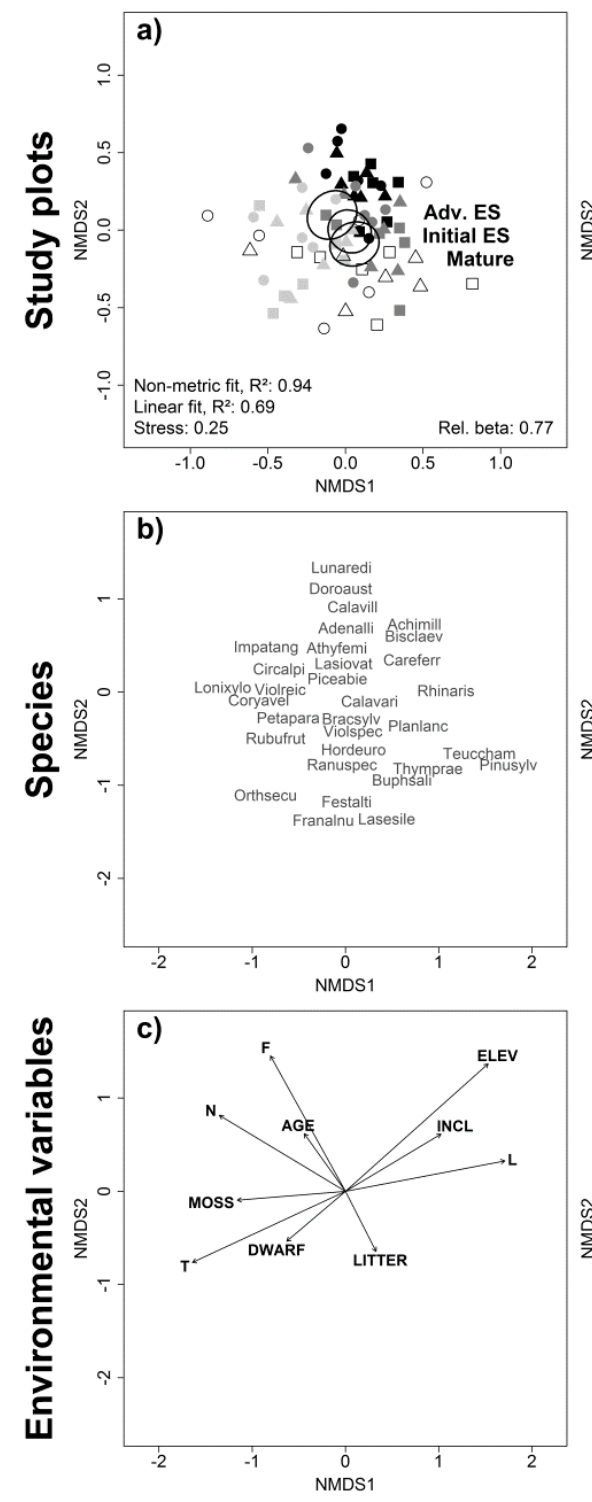

Study plots

Mature, montane, south-facing
north-facing
- $\quad$ high montane, south-facing
north-facing
Fungi
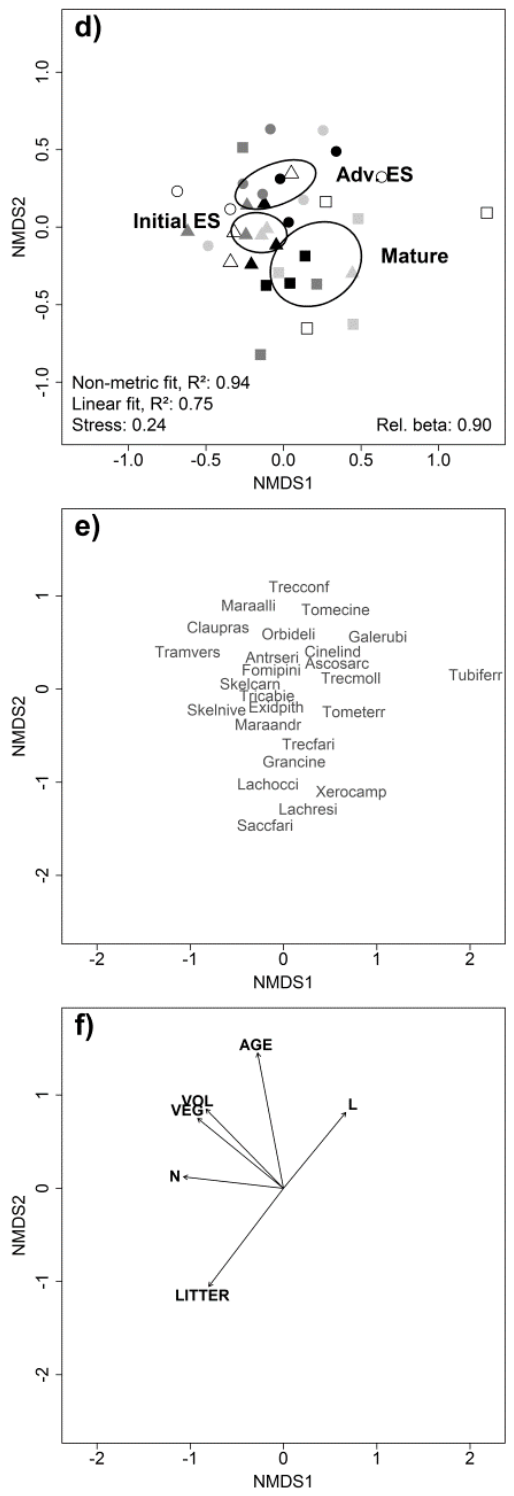

Beetles
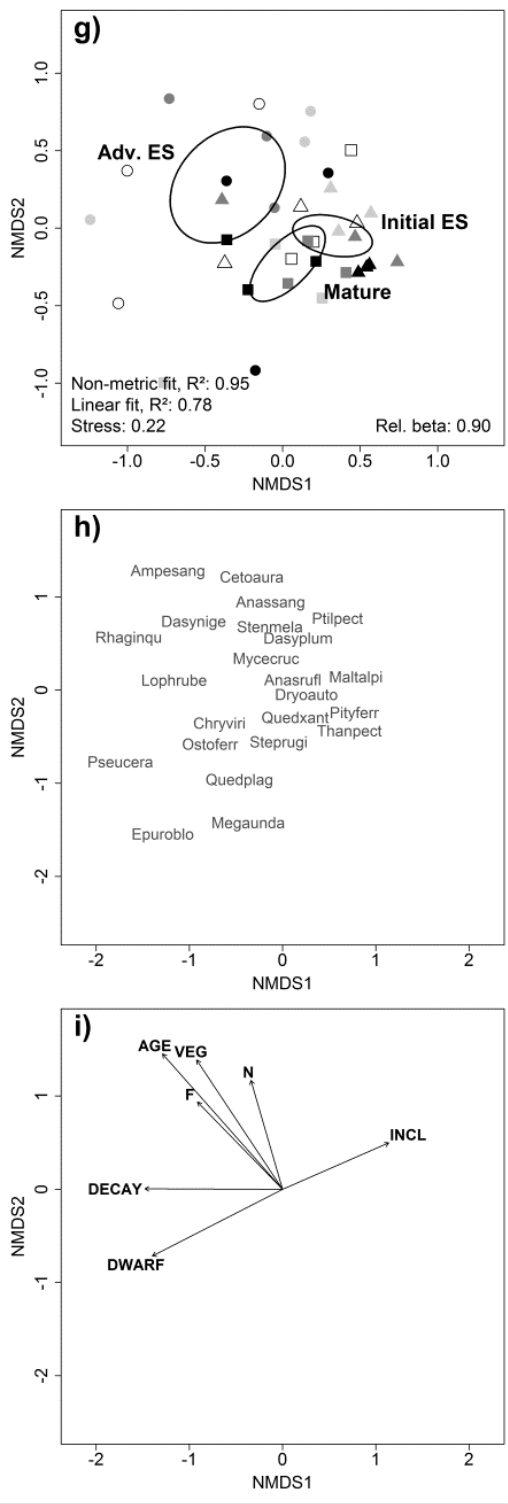
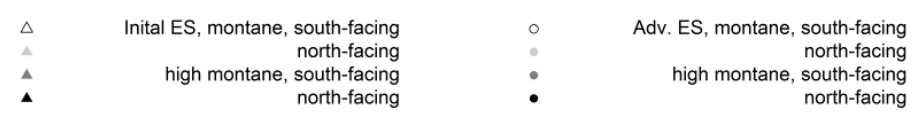

Fig 4.3 NMDS ordination diagrams of vascular plants, wood-inhabiting fungi and saproxylic beetles. The ordination of study plots, species composition and correlating environmental variables is based on one ordination per species group, but is illustrated in three graphs (rows 1-3) for clarity. The standard deviations of the averages of study plots of the same successional stage are depicted as the confidence interval (ellipse) in the first row and are a measure of beta diversity. Rel. beta refers to the observed relative beta diversity among study plots compared to the value of gamma diversity through additive diversity partitioning. The plotted names in graphs $b$, e and $h$ are the combined first four letters of the genus name and the first four letters of the species name (e.g. Festalti = Festuca altissima); only a selection of the most common species are plotted for clarity (Appendices 4.S5-4.S7). The definitions of the abbreviations of the environmental variables are given in Table 4.1. 
Abb. 4.3 NMDS-Ordination der Gefäßpflanzen, totholzbesiedelnden Pilze und totholzbesiedelnden Käfer. Die Ordination von Probeflächen, Artenzusammensetzung und korrelierenden Umweltparametern basiert auf einer Berechnung pro Artengruppe und ist zur vereinfachten Lesbarkeit in drei Graphiken (Zeilen 1-3) dargestellt. Die Standardabweichung der Probeflächen von der mittleren Lage aller Probeflächen eines Sukzessionsstadiums ist als Konfidenzintervall (Ellipse) in den Graphiken a, d und g abgebildet und ist eine Größe der Beta-Diversität. Rel. beta wurde durch additive Diversitäts-Auftrennung (additive diversity partitioning) berechnet und bezieht sich auf den Anteil der Beta-Diversität an der Gamma-Diversität. Die in Graphiken b, e und $\mathrm{h}$ dargestellten Namen sind eine Kombination der jeweils vier ersten Buchstaben von Gattungs- und Artnamen (z.B. Festalti = Festuca altissima). Zur vereinfachten Lesbarkeit sind nur die häufigsten Arten abgebildet (siehe Artenlisten in Anhängen S5-S7). Die Abkürzungen der Umweltparameter sind in Tabelle 1 erläutert.

\section{Discussion}

\section{Increasing spatial heterogeneity of forest structure}

Early successional stages that follow large-scale forest disturbances have been recognized as valuable phases of forest diversity (Swanson et al. 2011, 2014, Donato et al. 2012, Beudert et al. 2015). In our study, we found that two decades after the bark beetle-induced spruce dieback, trees were spatially clustered and both crown cover and regeneration density showed beta diversity values exceeding those of the mature stage, which indicates a high diversity of stand structures on the landscape scale. The observed spatial heterogeneity in regeneration density might be due to a large extent to the effects of elevation - regeneration density was significantly higher 20 years after the disturbance on montane plots than on high montane plots (Winter et al. 2015b). The initial early-seral stage could be, however, rather characterized as a short-term phase of structural homogenization concerning light conditions, indicated by the low beta diversity value of crown cover.

All dead-wood parameters except dead-wood volume showed the highest heterogeneity in mature stands. Both decay stage and dead-wood height are linked to time since tree dieback (Storaunet \& Rolstad 2002, Zielonka 2006). The dieback of single trees in the unmanaged stands of the mature stage is not linked to one specific temporal event or to one cause of death of numerous trees, unlike the large-scale dieback in the post-disturbance stands. This uniform dieback time in the postdisturbance stands might explain why the densities of the studied saproxylic species did not react to the strongly increasing dead-wood volumes as would be expected from previous studies (Sippola et al. 2004, Küffer \& Senn-Irlet 2005, Lonsdale et al. 2008, Bässler et al. 2012, 2015, Heilmann-Clausen et al. 2015; Heikkala et al. 2016). Dead wood characteristics determine the colonization of many species dependent on dead wood (e.g. Saint-German et al. 2007 and discussion below), but partly also influence forest succession by protecting against rockfall and avalanche release on steep slopes 
(Kupferschmid Albisetti et al. 2003) and as a seedbed that supports establishment and survival of spruce seedlings at higher elevations (Zielonka 2006, Winter et al. 2015b). We assume that the parameters regeneration density, crown closure and dead-wood volume are of prime importance in determining further forest succession at the landscape scale, in support of our hypothesis of structural diversity. However, as direct measurement of stand structural attributes does not capture all characteristics of forest heterogeneity (Ewald 2002), we analysed taxonomic, phylogenetic diversity and functional diversity measures of different species groups as indirect indicators of habitat complexity (Cadotte et al. 2013).

High spatial variation of vascular plants at the stand level but not at the landscape level

It is well known that the species density of ground vegetation can increase with increasing light (Ammer 1996, Bernhardt-Römermann et al. 2015) and that improved light availability in the earlyseral stage promotes light-demanding species (Lehnert et al. 2013, Winter et al. 2015a). Even smallscale disturbances that cause only minor changes in light and soil conditions can result in considerable changes in ground-layer vegetation in mountain spruce forests (Holeska 2003) when propagules of vascular plants are abundant and ensure a rapid establishment of highly competitive species (Davis et al. 2000, Reilly et al. 2006, Thorn et al. 2015). Our vegetation data showed a significant increase in species density of vascular plants at the alpha-diversity level on subplots and plots during the first two decades of bark beetle-induced forest succession, but no changes in beta diversity. Neither the NMDS ordination of species composition nor the evaluation of phylogenetic and functional diversity at the landscape scale in the advanced early-seral stage supported the hypothesis of an increased beta diversity of vascular plant assemblages with time since disturbance. Plant species composition was ordinated along a thermal gradient, as indicated by clustering of study plots of elevation and aspect class and by the high loading of the co-variables Ellenberg temperature indicator value and elevation. Even though mean-weighted structural beta diversity was highest in the advanced early-seral stage in our study, all plots seem to offer at least small amounts of relevant structures for plant species diversity (e.g. full light gradient, Ammer 1996). This might also explain why extrapolated gamma diversity of vascular plants, representing the mosaic of all three successional stages in the study area, did not consistently exceed the diversity of the single stages (Appendix 4.S11). Plant species beta diversity is, however, expected to increase once the canopy of some montane forest stands are completely closed while the canopy of others remain open for longer periods.

The three successional stages did not differ in phylogenetic alpha diversity on the plot level, but all three successional stages were characterized by phylogenetic overdispersion. Phylogenetic overdispersion in community assemblies, which represents a lower phylogenetic relatedness than 
expected from the null model, can indicate that competition between species is the prevailing process (Webb et al. 2002, Hoiss et al. 2012) and that in our study neither the disturbance event nor the post-disturbance succession leads to an overall filtering of plants species assemblages. However, overdispersion might also result from a relatively high level of structural heterogeneity in all stages that promote the establishment and survival of distant relatives, rather than from the competitive exclusion of closely related species (Li et al. 2015, Thorn et al. 2015).

\section{Changing species composition of wood-inhabiting fungi}

The species density of wood-inhabiting fungi is known to increase with the amount and diversity of coarse woody debris (Sippola et al. 2004, Küffer \& Senn-Irlet 2005, Lonsdale et al. 2008, Bässler et al. 2010, 2012, 2015, Heilmann-Clausen et al. 2015). Even though the dead-wood volume significantly increased because of bark beetle-induced spruce dieback in our study area, neither dead-wood diversity nor decay stage heterogeneity of dead wood increased during succession, which might explain the constant species densities on the alpha-diversity scale (Kebli et al. 2011). Moreover, a large-scale disturbance interrupts the supply of fine woody debris, which has been shown to substantially contribute to overall fungal species richness in forests (Heilmann-Clausen \& Christensen 2004, Bässler et al. 2010). Presumably, those relationships are also reflected in the NMDS ordination with the largest heterogeneity of fungal species assemblages in the mature stage. Wood-inhabiting fungi of all stages showed a tendency to phylogenetically cluster. Phylogenetic clustering of closely related species can be interpreted in terms of niche-related processes, where only closely related species with similar, conserved characteristics occur under given environmental filtering conditions in this case dead-wood parameters (Webb et al. 2002, Hoiss et al. 2012). The species compositions of the studied groups, however, did not differ among the three stages in terms of overdispersion or clustering. Therefore, neither the disturbance nor the subsequent succession generally shifted the assembly pattern towards habitat filtering (Bässler et al. 2015). The environmental variables with highest explanatory power of fungal species composition (time since spruce dieback, dead-wood volume and height of ground vegetation) all increased in value as succession proceeded, which might explain the shift in species assemblies among the successional stages, in contrast to plant species composition. Wood-inhabiting fungi did, however, not support our hypothesis of increased species beta diversity in the early-seral stages.

Overall functional beta diversity of wood-inhabiting fungi was higher in the post-disturbance stages, whereas the phylogeny of fungal species assemblages showed the lowest beta diversity in the advanced early-seral stage. In an analysis of the effect of logging on fungal community assembly processes, Bässler et al. (2014) found similar contradictory patterns of functional and phylogenetic 
results; their explanation for these patterns was that unmeasured traits reflected by phylogeny interact with the assembly mechanisms.

\section{Increasing beta diversity of saproxylic beetles}

From other studies it is known that both, the increased amount of spruce dead wood and the opening of the canopy caused by bark beetles have positive effects on the abundance of hostgeneralist and conifer-specialist guilds of saproxylic beetles (Müller et al. 2008, 2010). In contrast to the alpha diversity of wood-decaying fungi, the alpha diversity of saproxylic beetles peaks during initial stages and decreases quickly as nutrients are depleted (Kopf \& Funke 1998, Saint-German et al. 2007). Consistent with these results, we found highest numbers of saproxylic beetles that prefer wood in early stages of decay in the initial early-seral stage, following the availability of fresh dead wood. In contrast to our expectation, the pulse of fresh dead wood during the initial early-seral stage did not lead to increased phylogenetic or functional clustering of the saproxylic beetle assemblages, which was found, for instance, after retention cutting with subsequent die-off of retained trees (Heikkala et al. 2016).

The highest beta diversity values of species composition and phylogeny of saproxylic beetles were found in the advanced early-seral stage, thus supporting our hypothesis. The parameters time since spruce dieback, height of vegetation cover, and dead-wood decay stage showed the highest correlation to species composition of saproxylic beetles, similarly to the ordination of woodinhabiting fungi. The presence in the advanced early-seral stage of several saproxylic beetle species that, as adults, depend on large flowering plants, is consistent with the significantly higher coverage of flowering plant species in this stage (Winter et al. 2015a). In addition, acidic conditions in the upper organic soil layer of mature spruce stands, indicated by the large cover of dwarf shrubs (mainly Vaccinium myrtillus) on the plots (Baier et al. 2007), seem to influence the presence of saproxylic beetle species, thus leading to shifting species assemblies among the successional stages. Although most of the measured dead-wood conditions had the highest heterogeneity in the mature stage, the high beta diversity of saproxylic beetle species in the advanced early-seral stage might be a result of unmeasured heterogeneous conditions of dead wood in this stage. Sun-exposured dead wood for example has proven to be essential for various saproxylic beetles species (Seibold et al. 2015). Supporting the results of our study, the findings of Gossner et al. (2013) led to the conclusion that forest stand variables in Central European beech forests did not have a statistically significant effect on overall functional diversity of saproxylic beetles, but significantly affected community mean and diversity of single functional traits, e.g. large beetle species that are characterized by long developmental phases and low growth rates (Appendix 4.S3). 
We note that our sampling effort did not lead to a good representation of the regional species pool, neither for the wood-inhabiting fungi nor for the saproxylic beetles, probably owing to the generally high but partly unmeasured diversity in the national park area (Falkner 1997) and a low evenness, as indicated by the high proportion of singletons in the samples. The extrapolated gamma diversity of both species groups, representing the mosaic of all three successional stages in the study area, did, however, exceed the diversity of the single stages (Appendix 4.S11). This is in line with the results of Duelli et al. (2002), who evaluated the effects of windthrows on faunistic biodiversity in alpine spruce forests. They found the highest gamma diversity when species assemblages of mature stands and of logged and unlogged early-seral stands were combined, which presents a mosaic of different stand conditions on the landscape scale.

\section{Conclusions}

Our results support the hypothesis of continuing structural heterogeneity in advanced early-seral stages of forests during an extended open-canopy period at both local and regional scales. Spatial heterogeneity of several important structural elements did even exceed the level of the initial earlyseral stage. The results indicate that this structurally complex phase prior to tree canopy closure can last decades and might shape unmanaged mountain forests - at least at higher altitudes - even longer than the studied two decades. A remaining question is how much longer these open-canopy conditions may continue into the middle stages of succession and beyond. The fact that stand structure in the advanced early-seral stage was still diverging from, or at least not converging with, mature forest structure suggests the possibility for a more open-canopy pathway that could maintain structural complexity. Successional patterns of vascular plants, wood-inhabiting fungi and saproxylic beetles, which colonized the habitats of the studied stands, did not follow patterns of structural elements uniformly but correlated differently with single structural attributes. It seems, however, that the bark beetle that initiated a mosaic of different successional stages and the non-intervention policy of the national park did substantially increase the gamma diversity of wood-inhabiting fungi and saproxylic beetles in our study.

\section{Acknowledgements}

We thank Fritz Eder for supporting vegetation mapping, Peter Karasch and Andreas Gminder for mapping wood-inhabiting fungi, Alexander Szallies for determining the sampled beetles to the species level, many forestry students who supported the inventory of stand and regeneration attributes in the field and Karen Brune for linguistic revision of the manuscript. We are grateful to Roland Baier and Christian Ammer who initiated the project Forest dynamics following spruce bark beetle calamities in the National Park Berchtesgaden and gave valuable comments on a draft of this 
manuscript. The project was funded by the Bavarian State Ministry for the Environment and Public Health (StMUG). The work of M. Bernhardt-Römermann was partly supported by the Bavarian Academy for Nature Conservation and Landscape Management (ANL).

\section{References}

Ammer, C. 1996. Konkurrenz um Licht. Zur Entwicklung der Naturverjüngung im Bergmischwald. Forstliche Forschungsberichte München 158: 1-198.

Baier, R., Meyer, J., Göttlein, A. 2007. Regeneration niches of Norway spruce (Picea abies [L.] Karst.) saplings in small canopy gaps in mixed mountain forests of the Bavarian Limestone Alps. European Journal of Forest

Research 126: 11-22.

Bässler, C., Ernst, R., Cadotte, M., Heibl, C., Müller, J. \& Barlow, J. 2014. Near-to-nature logging influences fungal community assembly processes in a temperate forest. Journal of Applied Ecology 51 (4): 939-948.

Bässler, C., Müller, J., Cadotte, M.W., Heibl, C., Bradtka, J.H., Thorn, S. \& Halbwachs, H. 2015. Functional response of lignicolous fungal guilds to bark beetle deforestation. Ecological Indicators (in press).

Bässler, C., Müller, J., Dziock, F. \& Brandl, R. 2010. Effects of resource availability and climate on the diversity of wood-decaying fungi. Journal of Ecology 98 (4): 822-832.

Bässler, C., Müller, J., Svoboda, M., Lepšová, A., Hahn, C., Holzer, H. \& Pouska, V. 2012. Diversity of wooddecaying fungi under different disturbance regimes-a case study from spruce mountain forests. Biodiversity Conservation 21 (1): 33-49.

Beers, T., Dress, P. \& Wensel, L. 1966. Aspect transformation in site productivity research. Journal of Forest Research 64: 691-692.

Bernhardt-Römermann, M., Baeten, L., Craven, D., De Frenne, P., Hédl, R., Lenoir, J., Bert, D., Brunet, J., Chudomelová, M., (...) \& Verheyen, K. 2015. Drivers of temporal changes in temperate forest plant diversity vary across spatial scales. Global Change Biology 21: 3726-3737.

Beudert, B., Bässler, C., Thorn, S., Noss, R., Schröder, B., Dieffenbach-Fries, H., Foullois, N. \& Müller, J. 2015. Bark beetles increase biodiversity while maintaining drinking water quality. Conservation Letters 8 (4): $272-281$.

Bouget, C. \& Duelli, P. 2004. The effects of windthrow on forest insect communities: a literature review. Biological Conservation 118 (3): 281-299.

Braun-Blanquet, J. 1964. Pflanzensoziologie. 3rd edn. Springer, Wien, A.

Cadotte, M.W., Albert, C.H. \& Walker, S.C. 2013. The ecology of differences: assessing community assembly with trait and evolutionary distances. Ecology Letters 16: 1234-1244.

Cadotte, M.W., Carscadden, K. \& Mirotchnik, N. 2011. Beyond species: functional diversity and the maintenance of ecological processes and services. Journal of Applied Ecology 48: 1079-1087.

Campbell, J.L. \& Donato, D.C. 2014. Trait-based approaches to linking vegetation and food webs in early-seral forests of the Pacific Northwest. Forest Ecology and Managagement 324: 172-178.

Chao, A. 1987. Estimating the population size for capture-recapture data with unequal catchability. Biometrics 43: 783-791. 
Clark, P.J. \& Evans, F.C. 1954. Distance to nearest neighbor as a measure of spatial relationships in populations. Ecology 35 (4): 445-453.

Davis, M.A., Grime, P. \& Thompson, K. 2000. Fluctuating resources in plant communities: a general theory of invasibility. Journal of Ecology 88: 528-534.

Donato, D.C., Campbell, J.L. \& Franklin, J.F. 2012. Multiple successional pathways and precocity in forest development: can some forests be born complex? Journal of Vegetation. Science 23 (3): 576-584.

Duelli, P., Obrist, M.K. \& Wermelinger, B. 2002. Windthrow-induced changes in faunistic biodiversity in alpine spruce forests. Forest Snow and Landscape Research 77 (1/2): 117-131.

Ellenberg, H. \& Leuschner, C. 2010. Vegetation Mitteleuropas mit den Alpen. Ulmer, Stuttgart, D.

Ewald, J. 2002. Multiple controls of understorey plant richness in mountain forests of the Bavarian Alps. Phytocoenologia 32 (1): 85-100.

Falkner, G. 1997. Introduction to the malacological excursion to the Berchtesgaden National Park. Heldia 4 (5): 185-187.

Gossner, M.M., Lachat, T., Brunet, J., Isacsson, G., Bouget, C., Brustel, H., Brandl, R., Weisser, W. \& Müller, J. 2013. Current Near-to-Nature Forest Management Effects on Functional Trait Composition of Saproxylic Beetles in Beech Forests. Conservation Biology 27 (3): 605-614.

Graham, C.H., Parra, J.L., Rahbek C. \& McGuire, J.A. 2009. Phylogenetic structure in tropical hummingbird communities. PNAS 106: 19673-19678.

Heikkala, O., Seibold, S., Koivula, M., Martikainen, P., Müller, J., Thorn, S. \& Kouki, J. 2016. Retention forestry and prescribed burning result in functionally different saproxylic beetle assemblages than clear-cutting. Forest Ecology and Management 359: 51-58.

Heilmann-Clausen. J., Barron. E.S., Boddy. L., Dahlberg. A., Griffith. G.W., Nordén. J., Ovaskainen, O., Perini, C., Senn-Irlet, B. \& Halme, P. 2015. A fungal perspective on conservation biology. Conservation Biology 29 (1): $61-$ 68.

Hoiss, B., Krauss, J., Potts, S.G., Roberts, S. \& Steffan-Dewenter, I. 2012. Altitude acts as an environmental filter on phylogenetic composition, traits and diversity in bee communities. Proceedings of the Royal Society B: Biological Sciences 279 (1746): 4447-4456.

Holeska, J. 2003. Relationship between field-layer vegetation and canopy openings in a Carpathian subalpine spruce forest. Plant Ecology 168: 57-67.

Kebli, H., Drouin, P., Brais, S. \& Kernaghan, G. 2011. Species composition of saproxylic fungal communities on decaying logs in the boreal forest. Microbial ecology 61 (4): 898-910.

Knott, H., Bernhart, A. \& Feulner, M. 1988. Geschichte der Salinenwälder von Berchtesgaden. Nationalpark Berchtesgaden. Forschungsbericht 12.

Konnert, V. \& Siegrist, J. 2000. Waldentwicklung im Nationalpark Berchtesgaden von 1983 bis 1997. Nationalpark Berchtesgaden. Forschungsbericht 43.

Kopf, A. \& Funke, W. 1998. Xylobionte Arthropoden. In: Anton Fischer (Ed.): Die Entwicklung von WaldBiozönosen nach Sturmwurf. Ecomed, Landsberg, D. pp: 282-291. 
Köstler, J., Mayer, H. 1974. Gutachten über die künftige Behandlung des Waldes im Alpenpark Berchtesgadener Land. München, D.

Küffer, N. \& Senn-Irlet, B. 2005. Influence of Forest Management on the Species Richness and Composition of Wood-inhabiting Basidiomycetes in Swiss Forests. Biodiversity Conservation 14 (10): 2419-2435.

Kupferschmid Albisetti, A.D., Brang, P., Schönenberger, W. \& Bugmann, H. 2003. Decay of Picea abies snag stands on steep mountain slopes. The Forestry Chronicle 79 (2): 257.

Legendre, P. \& Legendre, L. 1998. Numerical ecology. 2nd English edn. Elsevier, Amsterdam, NL.

Lehnert, L.W., Bässler, C., Brandl, R., Burton, P.J. \& Müller, J. 2013. Conservation value of forests attacked by bark beetles: Highest number of indicator species is found in early successional stages. Journal for Nature Conservation 21 (2): 97-104.

Leyer, I. \& Wesche, K. 2007. Multivariate Statistik in der Ökologie: Eine Einführung. Springer. Berlin, Heidelberg.

Li, S.-P., Cadotte, M.W., Meiners, S.J., Hua, Z.-S., Jiang, L. \& Shu, W.-S. 2015. Species colonisation, not competitive exclusion, drives community overdispersion over long-term succession. Ecology Letters 18 (9): 964-973.

Lonsdale, D., Pautasso, M. \& Holdenrieder, O. 2008. Wood-decaying fungi in the forest: conservation needs and management options. European Journal of Forest Research 127 (1): 1-22.

Magurran, A.E. 2004. Measuring Biological Diversity. Blackwell Publishing, Malden (USA), Oxford (UK), Victoria (AUS).

McElhinny, C., Gibbons, P., Brack, C. \& Bauhus, J. 2005. Forest and woodland stand structural complexity: Its definition and measurement. Forest Ecology and Management 218: 1-24.

Müller, J., Bußler, H., Goßner, M., Rettelbach, T. \& Duelli, P. 2008. The European spruce bark beetle Ips typographus in a national park: from pest to keystone species. Biodiversity Conservation 17 (12): $2979-3001$.

Müller, J., Noss, R.F., Bussler, H. \& Brandl, R. 2010. Learning from a "benign neglect strategy" in a national park: Response of saproxylic beetles to dead wood accumulation. Biological Conservation 143 (11): 2559-2569.

Nationalpark Berchtesgaden 2001. Nationalparkplan. Nationalpark Berchtesgaden.

Ndiribe, C., Pellisier, L., Dubuis, A., Vittoz, P., Salamin, N. \& Guisan, A. 2014. Plant functional and phylogenetic turnover correlate with climate and land use in the Western Swiss Alps. Journal of Plant Ecology 7 (5): $439-450$.

Pausas, J.G. \& Verdú, M. 2010. The Jungle of Methods for Evaluating Phenotypic and Phylogenetic Structure of Communities. BioScience 60 (8): 614-625.

R Core Team 2013. R: A language and environment for statistical computing. R Foundation for Statistical Computing, Vienna, A. Online: http://cran.r-project.org.

Reilly, M.J., Wimberly, M.C. \& Newell, C.L. 2006. Wildfire effects on plant species richness at multiple spatial scales in forest communities of the southern Appalachians. Journal of Ecology 94 (1): 118-130.

Roberts, M.R. 2004. Response of the herbaceous layer to natural disturbance in North American forests. Canadian Journal of Botany 82 (9): 1273-1283. 
Saint-Germain, M., Drapeau, P.M. \& Buddle C. 2007. Host-use patterns of saproxylic phloeophagous and xylophagous Coleoptera adults and larvae along the decay gradient in standing dead black spruce and aspen. Ecography 30 (6): 737-748.

Schmidl, J. \& Bußler, H. 2004. Ökologische Gilden xylobionter Käfer Deutschlands. Naturschutz und Landschaftsplanung 36: 202-218.

Seibold, S., Brandl, R., Buse, J., Hothorn, T., Schmidl, J., Thorn \& S., Müller, J. 2015. Association of extinction risk of saproxylic beetles with ecological degradation of forests in Europe. Conservation Biology 29: 382-390.

Sippola, A.-L., Similä, M., Mönkkönen, M. \& Jokimäki, J. 2004. Diversity of Polyporous Fungi (Polyporaceae) in Northern Boreal Forests: Effects of Forest Site Type and Logging Intensity. Scandinavia Journal of Forest Research 19 (2): 152-163.

Smith, E.P. \& van Belle, G. 1984. Nonparametric estimation of species richness. Biometrics 40: 119-129.

Sousa, W.P. 1984. The Role of Disturbance in Natural Communities. Annual Review of Ecology, Evolution, and Systematics 15: 353-391.

Spandau, L. 1988. Angewandte Ökosystemforschung im Nationalpark Berchtesgaden. Nationalpark Berchtesgaden. Forschungsbericht 20.

Stein, A., Gerstner, K. \& Kreft, H. 2014. Environmental heterogeneity as a universal driver of species richness across taxa, biomes and spatial scales. Ecology Letters 17 (7): 866-880.

Storaunet, K.O. \& Rolstad, J. 2002. Time since death and fall of Norway spruce logs in old-growth and selectively cut boreal forest. Canadian Journal of Forest Research 32 (10): 1801-1812.

Swanson, M.E., Franklin, J.F., Beschta, R.L., Crisafulli, C.M., DellaSalla, D.A., Hutto, R.L., Lindenmayer, D.B. \& Swanson, F.J. 2011. The forgotten stage of forest succession: early successional ecosystems on forest sites. Frontiers in Ecolology and the Environment 9: 117-125.

Swanson, M.E., Studevant, N.M., Campbell, J.L. \& Donato, D.C. 2014. Biological associates of early-seral preforest in the Pacific Northwest. Forest Ecology and Management 324: 160-171.

Tews, J., Brose, U., Grimm, V., Tielbörger, K., Wichmann, M.C., Schwager, M. \& Jeltsch, F. 2004. Animal species diversity driven by habitat heterogeneity/diversity: the importance of keystone structures. Journal of Biogeography 31: 79-92.

Thorn, S., Bässler, C., Bernhardt-Römermann, M., Cadotte, M., Heibl, C., Schäfer, H., Seibold, S. \& Müller, J. 2015. Changes in the dominant assembly mechanism drive species loss caused by declining resources. Ecology Letters.

von Pechmann, F.D. 1932. Beiträge zur Geschichte der forstwirtschaft im oberbayerischen Hochgebirge. Forstwissenschaftliches Centralblatt 54 (18): 605-622.

Webb, C.O., Ackerly, D.D., McPeek, M.A. \& Donoghue, M.J. 2002. Phylogenies and Community Ecology. Annual Review of Ecology, Evolution, and Systematics 33: 475-505.

Westfall, P. \& Young S. 1993. Resampling-based Multiple Testing. John Wiley \& Sons, New York, US. 
Winter, M.-B., Ammer, C., Baier, R., Donato, D.C., Seibold, S. \& Müller, J. 2015a. Multi-taxon alpha diversity following bark beetle disturbance: Evaluating multi-decade persistence of a diverse early-seral phase. Forest Ecology and Management 338: 32-45.

Winter, M.-B., Baier, R. \& Ammer, C. 2015b. Regeneration dynamics and resilience of unmanaged mountain forests in the Northern Limestone Alps following bark beetle induced spruce dieback. European Journal of Forest Research 134 (6): 949-968.

Zenner, E.K. 2005. Development of Tree Size Distributions in Douglas-Fir Forests under Differing Disturbance Regimes. Ecological Applications 15 (2): 701-714.

Zielonka, T. 2006. Quantity and decay stages of coarse woody debris in old-growth subalpine spruce forests of the western Carpathians, Poland. Canadian Journal of Forest Research 36 (10): 2614-2622.

\section{Supporting Information}

Additional Supporting Information may be found in the online version of this article:

Appendix 4.S1. Community phylogeny estimation

Appendix 4.S2. Details of the construction of functional trait matrices

Appendix 4.S3. Results and discussion of single functional traits

Appendix 4.S4. Table of mean values and beta diversity of single functional traits of vascular plants, wood-inhabiting fungi and saproxylic beetles of the three successional stages.

Appendix 4.S5. Species list of vascular plants and their constancy on the plots of the three successional stages.

Appendix 4.S6. Species list of wood-inhabiting fungi and their constancy on the plots of the three successional stages.

Appendix 4.S7. Species list of saproxylic beetles and their constancy on the plots of the three successional stages.

Appendix 4.S8. Community phylogeny of vascular plants.

Appendix 4.S9. Community phylogeny of wood-inhabiting fungi.

Appendix 4.S10. Community phylogeny of saproxylic beetles.

Appendix 4.S11. Observed and estimated species numbers of vascular plants, wood-inhabiting fungi and saproxylic beetles 


\section{Supporting information}

to the paper Winter et al. High spatial heterogeneity of early-seral forest stands affects diversity of producers, consumers and decomposers differently. Journal of Vegetation Science

Appendix 4.S1. Community phylogeny estimation

\section{Vascular plants}

The community phylogeny of vascular plants on our study sites (Appendix 4.S8) was taken from a mega-phylogeny estimate for the complete German flora. To estimate the mega-phylogeny, we used the taxon list of Wisskirchen \& Haeupler (1998) and ran PHLAWD (Smith et al. 2009) searches in the GenBank database (ftp://ftp.ncbi.nih.gov/genbank/) for 17 DNA regions: 18S ribosomal RNA genes, $26 \mathrm{~S}$ rRNA genes, atpB, matK, matR, ndhF, rbcL, rpl16, rpl20-rps12, rps4, rps16, trnH-psbA, trnK, trnL/trnL-trnF, trnS-trnG, and rRNA gene external transcribed spacer (ETS) and internal transcribed spacer (ITS) regions. The aligned output matrices from PHLAWD were concatenated using Phyutility v2.4 (Smith \& Dunn 2008). The combined matrices were used in maximum-likelihood tree searches in RAxML-Light v1.0.3 (Stamatakis et al. 2008). The best-scoring maximum-likelihood tree for the German flora was inspected by eye for unusually long branches, and the few misplaced taxa were removed. We then used the function drop.tip from the R package ape to prune all taxa from the tree that were not present on the study plots.

\section{Wood-inhabiting fungi}

The community phylogeny of fungi present on the study plots (Appendix 4.59) was estimated using the $\mathrm{R}$ package megaptera, a pipeline for large-scale automated sequence retrieval and alignment. First, we downloaded all sequences of six gene regions (18S rRNA genes, 28s rRNA genes, 5.8s rRNA genes, $r p b / 1, r p b / 2$, tef1) of the fungal taxa found on the plots and their taxonomy from GenBank (Benson et al. 2012). In the next step, megaptera was used to align conspecific species sequences (identical organism name) and build consensus sequences by majority rule criterion. If no reference sequences were provided for the functions, megaptera constructed benchmark sequences automatically. We chose three to six published reference sequences for each gene region, which were sampled according to the subphyla (Agaricomycotina, Pucciniomycotina, Ustilaginomycotina). For each con-specifically aligned species sequence, megaptera calculated the identity (proportion of identical nucleotides) and coverage (proportion of nucleotide positions of a sequence in common) relative to the reference sequences. Based on the coverage and identity values, thresholds could be adjusted for each marker separately to maximize both quality and number of taxa. The default values were 0.75 for identity and 0.5 for coverage. We set identity thresholds to 0.5 for $r p b 1, r p b 2$, and 
25S sRNA genes. We aligned the remaining consensus species sequences using MAFFT (Katoh et al. 2002). Then we used the function Gblocks (package ips, Castresana 2000, Talavera \& Castresana 2007) to mask the alignment by reducing it by removing ambiguously alienable and saturated regions. The gap treatment was set to 50\%, i.e. gaps were only kept in the alignment if at least $50 \%$ of the sequences exhibit a specific gap. Maximum-likelihood was estimated using the concatenated supermatrix of the six gene regions using RAxML (Stamatakis et al. 2008) on the CIPRES Science Gateway v.3.3 (RAxML -HPC2 on XSEDE 8.1.1, Miller et al. 2010, 2011). We conducted the GTR model with rate heterogeneity enabled and bootstrapping set at auto halt. Each of the six gene regions was treated as a separate partition. As outgroup, we used 12 species of Glomus (G. aggregatum, G. deserticola, G. invermaium, G. versiforme, G. compressum, G. macrocarpum, G. cerebriforme, G. cubense, G. indicum, G. multiforum, G. dimorphicum, G. hoi, G. pulvinatum) which exhibited highest coverage values relative to the reference sequences. The resulting tree was converted to an ultrametric tree using PATHd8 V. 1.9.8 (Britton et al. 2006).

Since sequence data of rare fungal species were not available, we removed all 121 fungal singletons (species that were only recorded once during the study). The mean share of fungal singletons on the plots was $10.8 \%$ ( $\pm 1.23 \%$ two-fold standard error); the number of singletons on the three successional stages did not significantly differ (Appendix 4.S6).

\section{Saproxylic beetles}

The community phylogeny of saproxylic beetles on our study sites (Appendix 4.S10) was taken from Seibold et al. (2015), who modified the comprehensive phylogeny of Hunt et al. (2007) to include all relevant Bavarian taxa. 
Appendix 4.S2. Details of the construction of functional trait matrices

To characterize vascular plant assemblages, we used 12 traits (e.g. Bernhardt-Römermann et al. 2008, see Appendix 4.S4): (i) canopy height, (ii) vegetative lateral spread, (iii) duration of flowering period (flower duration), (iv) start of flowering period (flower start), (v) seed weight, (vi) persistence, (vii) life form, (viii) leaf distribution, (ix) leaf anatomy, (x) reproduction type (reproduction), (xi) pollen vector and (xii) seed dispersal type (seed dispersal). To characterize wood-inhabiting fungi assemblages, we used five traits described in Bässler et al. (2015): (i) volume fruiting body, (ii) volume spore, (iii) persistence, (iv) ectomycorrhizal species (ectomycorrhiza) and (v) growing substrate (substrate). As in the phylogeny, singletons were excluded from species lists. To characterize saproxylic beetle assemblages, we used six traits described in Seibold et al. (2015): (i) body size; (ii) preference for particular trunk diameter (wood diameter niche); (iii) preference for particular decay stage (decay niche); (iv) preference for particular level of canopy cover (canopy niche); (v) habit of adult beetles for visiting flowers (flower visiting) and (vi) larval foraging strategy (foraging strategy).

For categorical functional traits, we distinguished between two cases according to the method of Bernhardt-Römermann et al. (2008): (1) traits for which several entries of different attributes are likely (e.g. one species can be dispersed by several dispersal types), and (2) traits with only one possible attribute per species. The traits of the second case as well as numerical traits were included in the analyses without further transformation; the traits of the first case (e.g. dispersal type) were dummy transformed, and the values in this system were weighted by the number of database entries per category. By definition, the sum per species of all values of each of these traits is 1 (BernhardtRömermann et al. 2008). 
Appendix 4.S3. Results and discussion of single functional traits

The analysis of mean trait values and trait attribute shares of vascular plants revealed significant differences between the advanced early-seral stage and the mature and initial early-seral stages, namely higher canopy height, increase in the ratio of regularly separated leaves along the stem, increase in the portion of therophytes and phanerophytes, and increasing importance of reproduction by seeds. At the same time, the proportion of plants with rosette leaves, cryptophyte life form and vegetative reproduction were lower in the advanced early-seral stage than in the mature or initial early-seral stage. Many of the single functional traits had high beta diversity values in the advanced early-seral stage, but only a few exceeded the values of the mature stage, namely pollen vector and persistence of vascular plants (Appendix 4.S4).

We interpreted the single functional traits of vascular plants as indicating that post-disturbance succession increases the relative share of phanerophytes with increasing regeneration densities and also the importance of reproduction by seeds. Species that reproduce by seeds can colonize disturbed sites more easily, but are known to be less competitive than species that reproduce vegetatively (Prach \& Pyšek 1999). The increasing importance of seed reproduction might be, however, also attributed to the tree species present representing a large part of vegetation cover in the advanced early seral stage and reproducing predominately by seeds. With regard to beta diversity, leaf persistence and pollen vector support our hypothesis that spatial heterogeneity is highest in the advanced early-seral stage. Both traits are important for persistence and regeneration, thereby increasing competition ability on the landscape scale (Schulze et al. 2002).

For wood-inhabiting fungi, both the mean volumes of fruiting bodies and proportion of perennials were higher in the advanced early-seral stage than in the undisturbed mature stage and the earlyseral stage, but spore volumes were smaller. Only persistence showed a beta-diversity value in the advanced early-seral stage that exceeded the value of the mature stage (Appendix 4.S4).

In our study, advanced post-disturbance conditions favoured perennial fungal species and fungal species with larger fruiting bodies. Mean volume of fruiting bodies increased significantly during succession, which indicated the availability of large volumes and diameters of dead wood in an advanced decay stage two decades after spruce dieback. The similarly increasing variation in fruiting body volume among plots of the same stage could be explained by the correspondingly increasing beta-diversity values of dead-wood volume. We assume, however, that the variation can be mainly assigned to the mapped abundances of the large-volume species Fomitopsis pinicola and Antrodia serialis, which might be biased through time-standardized mapping. Lower mean spore volumes in the advanced early-seral stage together with homogeneity of spore volume on the landscape scale 
suggest that pioneer species or r-strategists colonized the post-disturbance plots. Noros (2013) has shown that spore size is a relevant dispersal trait in terms of determining spore deposition from the air to a surface and that small spores disperse considerably farther than large spores. If small-spore species already reached the initial early-seral stages, which is plausible, they did not yet form fruiting bodies.

Saproxylic beetles in the advanced early-seral stage comprised fewer xylophagous species, were on average larger and showed stronger preferences for closed canopies, decomposed wood and flowering plants than in the mature and early-seral stages. The saproxylic beetle traits body size and flower visit had higher beta-diversity values in the advanced early-seral stage than in the mature stage (Appendix 4.S4).

Similar to our study, the findings of Gossner et al. (2013) led to the conclusion that forest stand variables in Central European beech forests did not have a statistically significant effect on overall functional diversity of saproxylic beetles, but significantly affected community mean and diversity of single functional traits, e.g. large beetle species that are characterized by long developmental phases and low growth rates. The preference of saproxylic beetle species for flowering plants in the advanced early-seral stage is consistent with the significantly higher coverage of flowering plant species in this stage (Winter et al. 2015). 


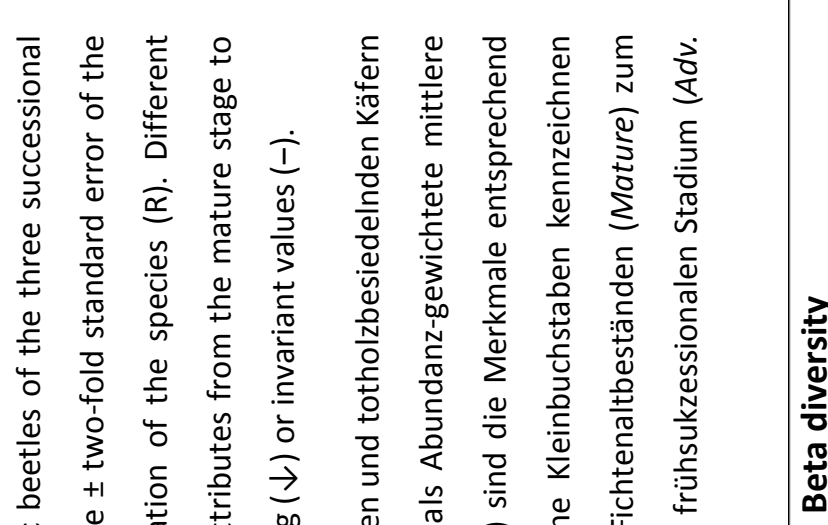

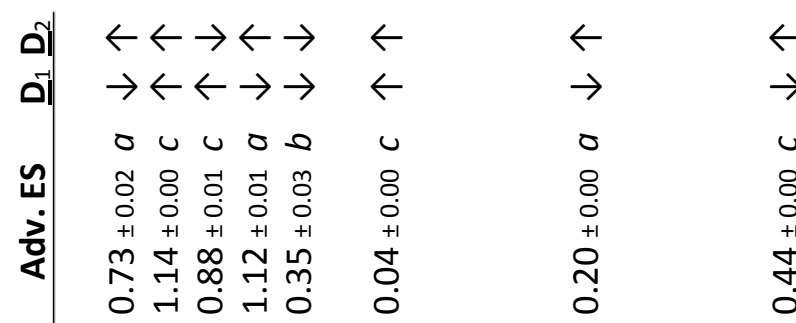

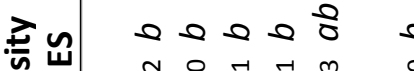

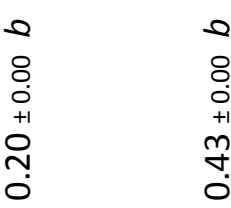

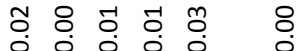

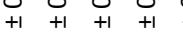

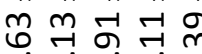

०ं

$\leftarrow$

$\begin{array}{llllllllll}0 & 0 & 0 & 0 & 0 & 0\end{array}$

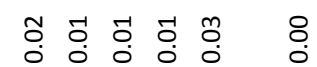

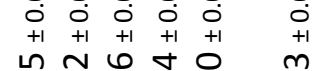

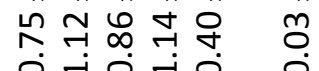

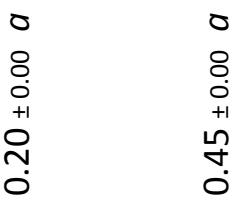

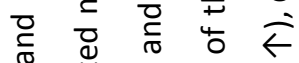

$\sum_{\sum}^{\frac{\pi}{20}}$

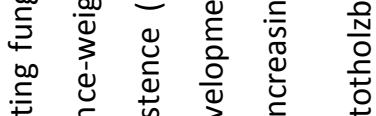

蒙

웅

๑ी $\leftarrow 1 \leftarrow 1 \quad 1 \quad 1 \leftarrow \rightarrow \leftarrow 1 \rightarrow 1 \leftarrow 1 \leftarrow 1 \rightarrow$

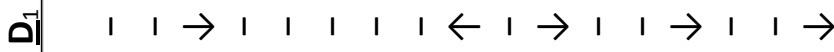

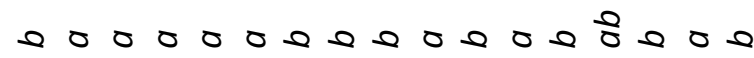

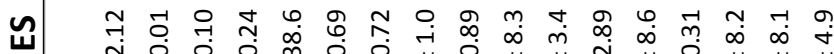

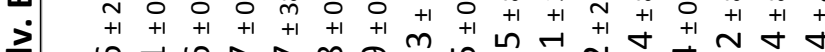
ம்

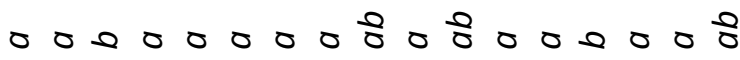

常 $\begin{aligned} & 0 \\ & 0\end{aligned}$

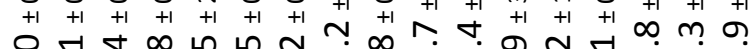

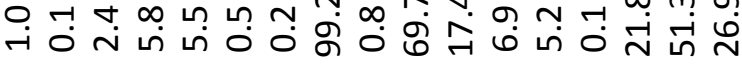

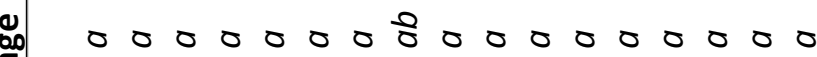
भी

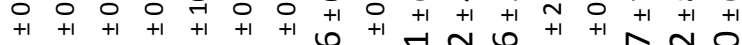


岀

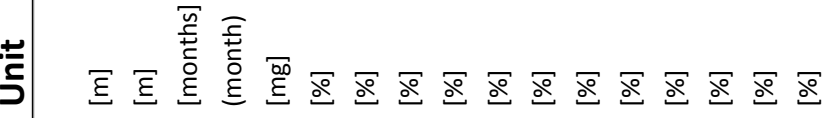

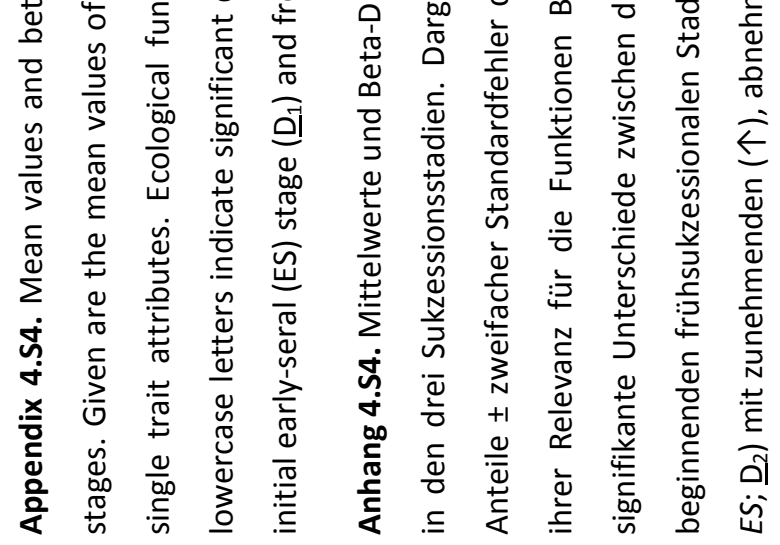

\section{艺}

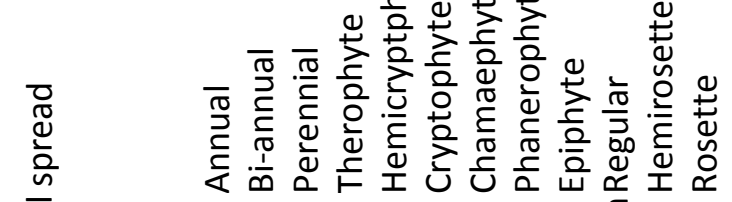
$\frac{\pi}{\frac{\pi}{20}}$

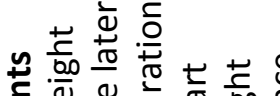

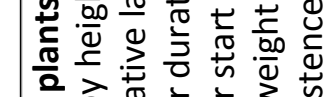

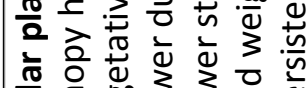

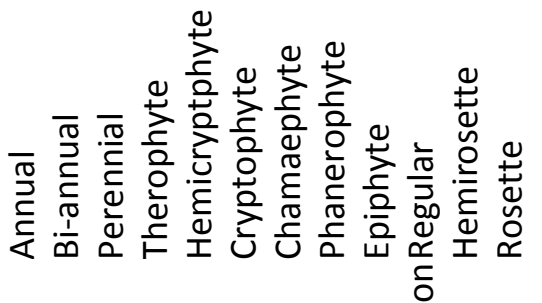




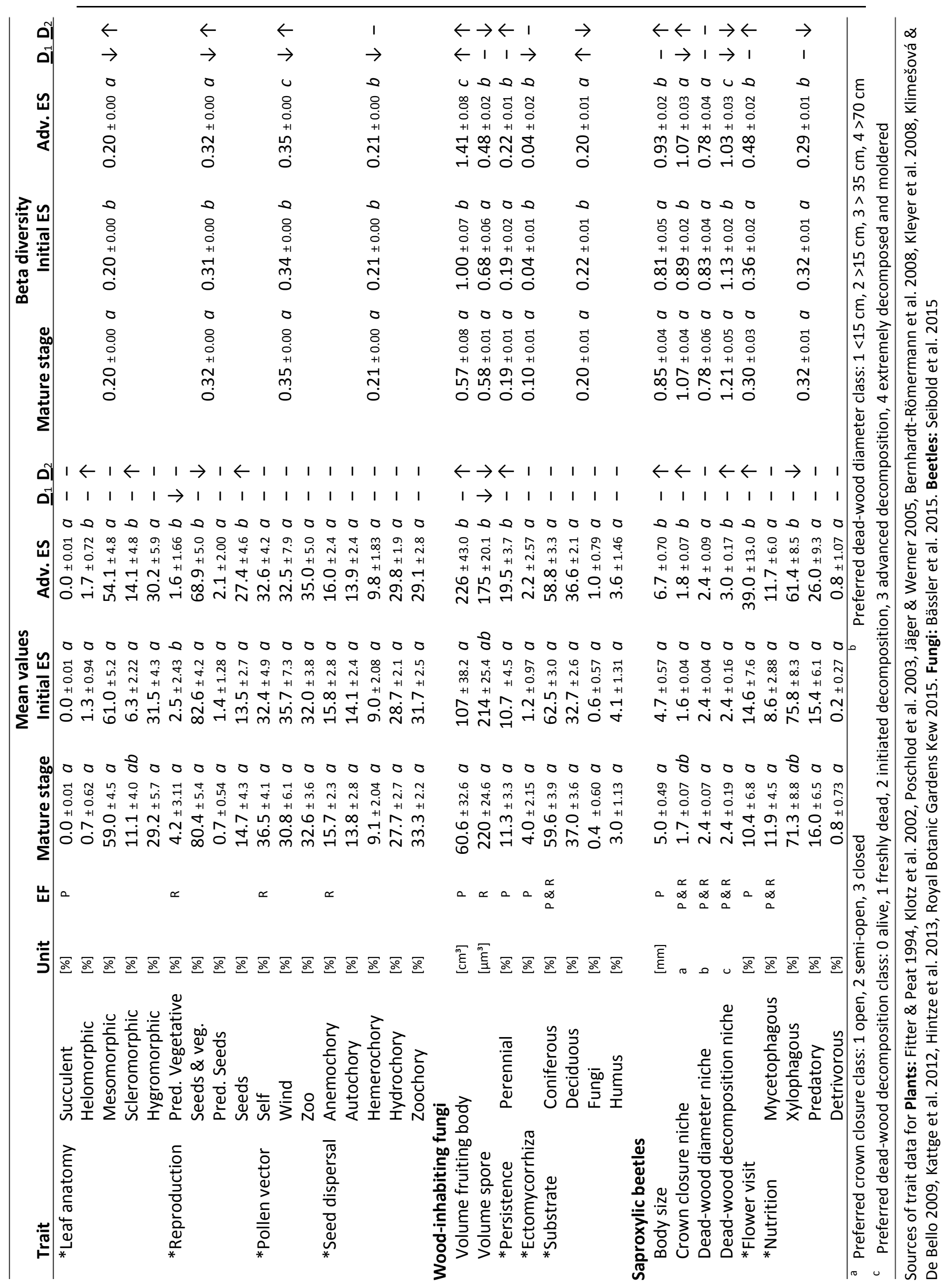


Appendix 4.S5. Species list of vascular plants and their constancy on the 24 plots of each of the three successional stages. Mature: mature stage, Initial ES: initial early-seral stage, Adv. ES: advanced early-seral stage. A total of 327 vascular plant species were mapped, with 232 species in the mature stage, 230 species in the initial-early seral stage and 280 species in the advanced early-seral stage.

Anhang 4.S5. Artenliste der Gefäßpflanzen und deren Stetigkeit auf den je 24 Probeflächen der drei Sukzessionsstadien. Mature: Fichtenaltbestand, Initial ES: beginnende Sukzession, Adv. ES: fortschreitende Sukzession. Insgesamt wurden 327 Arten erfasst mit 232 Arten in den Fichtenaltbeständen, 230 Arten im Stadium der beginnenden Sukzession und 280 Arten im Stadium der fortschreitenden Sukzession.

\begin{tabular}{|c|c|c|c|c|c|c|c|}
\hline Species & Mature & Initial ES & Adv. ES & Species & Mature & Initial ES & Adv. ES \\
\hline Abies alba & 11 & 5 & 12 & Horminum pyrenaicum & 0 & 0 & 1 \\
\hline Acer platanoides & 2 & 1 & 1 & Huperzia selago & 20 & 17 & 14 \\
\hline Acer pseudoplatanus & 23 & 24 & 24 & Hypericum maculatum & 11 & 9 & 12 \\
\hline Achillea clavennae & 0 & 0 & 1 & Hypericum perforatum & 0 & 0 & 5 \\
\hline Achillea millefolium & 1 & 0 & 1 & Impatiens noli-tangere & 0 & 1 & 3 \\
\hline Acinos alpinus & 3 & 4 & 3 & Juncus effusus & 0 & 0 & 1 \\
\hline Aconitum lycoctonum & 6 & 11 & 11 & Juncus trifidus & 0 & 0 & 1 \\
\hline Aconitum napellus & 2 & 1 & 4 & Kernera saxatilis & 0 & 0 & 1 \\
\hline Actaea spicata & 6 & 6 & 5 & Knautia dipsacifolia & 12 & 11 & 13 \\
\hline Adenostyles alliariae & 6 & 9 & 9 & Larix decidua & 10 & 10 & 13 \\
\hline Adenostyles alpina & 22 & 22 & 24 & Laserpitium latifolium & 1 & 1 & 1 \\
\hline Aegopodium podagraria & 0 & 1 & 1 & Laserpitium siler & 1 & 0 & 0 \\
\hline Agrostis capillaris & 0 & 1 & 3 & Leontodon hispidus & 1 & 0 & 1 \\
\hline Agrostis rupestris & 0 & 0 & 1 & Leontodon hispidus & 0 & 0 & 1 \\
\hline Agrostis schleicheri & 0 & 5 & 4 & Leontodon incanus & 0 & 0 & 1 \\
\hline Agrostis stolonifera & 1 & 2 & 2 & Leucanthemum vulgare & 0 & 0 & 1 \\
\hline Ajuga reptans & 7 & 6 & 6 & Lilium martagon & 9 & 10 & 6 \\
\hline Alchemilla hoppeana & 0 & 2 & 1 & Linum catharticum & 1 & 0 & 0 \\
\hline Alchemilla monticola & 1 & 0 & 1 & Listera cordata & 2 & 0 & 0 \\
\hline Alchemilla subcrenata & 0 & 1 & 0 & Listera ovata & 10 & 12 & 14 \\
\hline Alchemilla vulgaris & 0 & 0 & 1 & Lonicera alpigena & 8 & 10 & 10 \\
\hline Alnus incana & 1 & 0 & 0 & Lonicera caerulea & 0 & 0 & 1 \\
\hline Amelanchier ovalis & 2 & 1 & 1 & Lonicera nigra & 14 & 12 & 13 \\
\hline Anemone nemorosa & 0 & 0 & 1 & Lonicera xylosteum & 3 & 2 & 3 \\
\hline Angelica sy/vestris & 1 & 1 & 1 & Lotus corniculatus & 4 & 1 & 3 \\
\hline Anthericum ramosum & 2 & 0 & 0 & Lunaria rediviva & 0 & 0 & 1 \\
\hline Anthoxanthum odoratum & 0 & 2 & 1 & Luzula Iuzulina & 6 & 7 & 9 \\
\hline Anthyllis vulneraria & 1 & 0 & 0 & Luzula luzuloides & 0 & 1 & 2 \\
\hline Aposeris foetida & 11 & 12 & 13 & Luzula multiflora & 1 & 5 & 6 \\
\hline Aquilegia atrata & 5 & 9 & 4 & Luzula pilosa & 2 & 2 & 4 \\
\hline Arabis alpina & 1 & 1 & 1 & Luzula sylvatica & 10 & 10 & 9 \\
\hline Arabis pumila & 1 & 0 & 0 & Lycopodium annotinum & 16 & 14 & 17 \\
\hline Aruncus dioicus & 3 & 1 & 3 & Lysimachia nemorum & 15 & 18 & 24 \\
\hline Asplenium ruta-muraria & 11 & 9 & 8 & Maianthemum bifolium & 18 & 20 & 17 \\
\hline
\end{tabular}


Appendix 4.S5. continued

Anhang 4.S5. Fortsetzung

\begin{tabular}{|c|c|c|c|c|c|c|c|}
\hline Species & Mature & Initial ES & Adv. ES & Species & Mature & Initial ES & Adv. ES \\
\hline Asplenium trichomanes & 11 & 12 & 12 & Medicago lupulina & 0 & 0 & 1 \\
\hline Asplenium viride & 19 & 19 & 20 & Melampyrum sylvaticum & 16 & 8 & 9 \\
\hline Aster bellidiastrum & 20 & 17 & 15 & Melica nutans & 20 & 19 & 18 \\
\hline Athyrium distentifolium & 1 & 2 & 4 & Mentha longifolia & 0 & 0 & 1 \\
\hline Athyrium filix-femina & 21 & 21 & 24 & Mercurialis perennis & 20 & 20 & 22 \\
\hline Atropa belladonna & 0 & 8 & 5 & Microstylis monophyllos & 0 & 0 & 1 \\
\hline Berberis vulgaris & 0 & 0 & 1 & Moehringia muscosa & 20 & 21 & 22 \\
\hline Betula pubescens & 0 & 0 & 4 & Moehringia trinervia & 0 & 8 & 6 \\
\hline Biscutella laevigata & 1 & 0 & 0 & Molinia arundinacea & 0 & 0 & 4 \\
\hline Blechnum spicant & 4 & 2 & 3 & Moneses uniflora & 2 & 0 & 2 \\
\hline Botrychium lunaria & 0 & 0 & 2 & Monotropa hypopitys & 1 & 0 & 0 \\
\hline Botrychium virginianum & 0 & 0 & 1 & Mycelis muralis & 16 & 24 & 20 \\
\hline Brachypodium sylvaticum & 13 & 16 & 20 & Myosotis alpestris & 2 & 3 & 4 \\
\hline Briza media & 1 & 0 & 0 & Myosotis sylvatica & 0 & 2 & 1 \\
\hline Bromus benekenii & 0 & 1 & 1 & Nardus stricta & 1 & 0 & 1 \\
\hline Buphthalmum salicifolium & 3 & 4 & 3 & Neottia nidus-avis & 10 & 3 & 3 \\
\hline Calamagrostis varia & 24 & 24 & 23 & Origanum vulgare & 7 & 7 & 6 \\
\hline Calamagrostis villosa & 1 & 1 & 2 & Orobanche salviae & 0 & 0 & 1 \\
\hline Calluna vulgaris & 0 & 0 & 1 & Orthilia secunda & 1 & 1 & 0 \\
\hline Campanula cochleariifolia & 14 & 18 & 13 & Oxalis acetosella & 22 & 24 & 24 \\
\hline Campanula scheuchzeri & 19 & 17 & 16 & Paris quadrifolia & 23 & 22 & 22 \\
\hline Campanula trachelium & 6 & 4 & 2 & Petasites albus & 8 & 7 & 12 \\
\hline Cardamine enneaphyllos & 14 & 13 & 16 & Petasites paradoxus & 0 & 1 & 2 \\
\hline Cardamine flexuosa & 4 & 12 & 9 & Peucedanum ostruthium & 0 & 3 & 2 \\
\hline Cardamine impatiens & 0 & 1 & 0 & Phegopteris connectilis & 8 & 10 & 22 \\
\hline Carduus defloratus & 10 & 12 & 10 & Phyllitis scolopendrium & 2 & 0 & 3 \\
\hline Carduus personata & 1 & 0 & 0 & Phyteuma orbiculare & 5 & 3 & 3 \\
\hline Carex alba & 12 & 11 & 14 & Phyteuma spicatum & 16 & 14 & 13 \\
\hline Carex brachystachys & 5 & 6 & 7 & Picea abies & 24 & 22 & 24 \\
\hline Carex digitata & 17 & 16 & 15 & Pimpinella major & 8 & 6 & 5 \\
\hline Carex ferruginea & 8 & 6 & 7 & Pinus cembra & 0 & 0 & 1 \\
\hline Carex firma & 0 & 0 & 1 & Pinus sylvestris & 1 & 0 & 0 \\
\hline Carex flacca & 5 & 6 & 9 & Plantago lanceolata & 1 & 1 & 0 \\
\hline Carex flava & 2 & 0 & 3 & Plantago major & 0 & 2 & 0 \\
\hline Carex muricata & 0 & 1 & 0 & Plantago media & 0 & 1 & 0 \\
\hline Carex ornithopoda & 8 & 6 & 9 & Platanthera bifolia & 1 & 0 & 0 \\
\hline Carex ovalis & 0 & 1 & 1 & Poa alpina & 0 & 2 & 2 \\
\hline Carex pallescens & 0 & 1 & 4 & Poa annua & 0 & 2 & 0 \\
\hline Carex sempervirens & 0 & 0 & 1 & Poa nemoralis & 5 & 11 & 13 \\
\hline Carex sylvatica & 9 & 12 & 13 & Poa pratensis & 0 & 1 & 2 \\
\hline Carlina acaulis & 1 & 1 & 1 & Poa trivialis & 0 & 6 & 5 \\
\hline Centaurea jacea & 1 & 0 & 1 & Polygala chamaebuxus & 8 & 7 & 7 \\
\hline Centaurea montana & 4 & 7 & 4 & Polygonatum multiflorum & 1 & 0 & 1 \\
\hline Cephalanthera longifolia & 3 & 2 & 1 & Polygonatum odoratum & 6 & 5 & 2 \\
\hline
\end{tabular}


Appendix 4.S5. continued

Anhang 4.S5. Fortsetzung

\begin{tabular}{|c|c|c|c|c|c|c|c|}
\hline Species & Mature & Initial ES & Adv. ES & Species & Mature & Initial ES & Adv. ES \\
\hline Cerastium fontanum & 0 & 1 & 1 & Polygonatum verticillatum & 22 & 21 & 16 \\
\hline Chaerophyllum hirsutum & 10 & 9 & 17 & Polygonum viviparum & 2 & 0 & 1 \\
\hline Chaerophyllum villarsii & 2 & 2 & 2 & Polypodium vulgare & 6 & 6 & 9 \\
\hline Chrysosplenium alternifolium & 2 & 4 & 7 & Polystichum aculeatum & 15 & 12 & 21 \\
\hline Cicerbita alpina & 0 & 1 & 2 & Polystichum lonchitis & 8 & 7 & 12 \\
\hline Circaea alpina & 1 & 9 & 11 & Populus tremula & 0 & 0 & 1 \\
\hline Circaea lutetiana & 0 & 0 & 1 & Potentilla erecta & 9 & 4 & 8 \\
\hline Cirsium arvense & 0 & 0 & 1 & Prenanthes purpurea & 19 & 18 & 16 \\
\hline Cirsium oleraceum & 0 & 1 & 4 & Primula auricula & 0 & 0 & 1 \\
\hline Cirsium palustre & 1 & 2 & 4 & Primula elatior & 1 & 0 & 1 \\
\hline Cirsium spinosissimum & 0 & 0 & 1 & Prunella vulgaris & 1 & 1 & 2 \\
\hline Cirsium vulgare & 3 & 3 & 2 & Prunus avium & 0 & 1 & 0 \\
\hline Clematis alpina & 11 & 9 & 14 & Ranunculus alpestris & 2 & 0 & 0 \\
\hline Clematis vitalba & 0 & 0 & 2 & Ranunculus lanuginosus & 0 & 2 & 3 \\
\hline clinopodium vulgare & 5 & 6 & 9 & Ranunculus montanus & 4 & 7 & 4 \\
\hline Coeloglossum viride & 2 & 3 & 3 & Ranunculus nemorosus & 15 & 15 & 17 \\
\hline Convallaria majalis & 1 & 0 & 0 & Ranunculus platanifolius & 1 & 2 & 2 \\
\hline Corallorhiza trifida & 5 & 0 & 0 & Rhamnus catharticus & 2 & 0 & 0 \\
\hline Corylus avellana & 8 & 9 & 7 & Rhinanthus aristatus & 1 & 0 & 3 \\
\hline Cotoneaster integerrimus & 0 & 1 & 0 & Ribes alpinum & 0 & 0 & 3 \\
\hline Crepis paludosa & 6 & 4 & 5 & Rosa pendulina & 15 & 18 & 18 \\
\hline Cynoglossum officinale & 0 & 1 & 0 & Rubus fruticosus & 3 & 10 & 12 \\
\hline Cystopteris fragilis & 13 & 14 & 16 & Rubus idaeus & 16 & 19 & 23 \\
\hline Cystopteris montana & 3 & 2 & 4 & Rubus saxatilis & 12 & 7 & 7 \\
\hline Cystopteris regia & 1 & 0 & 0 & Rumex alpestris & 1 & 0 & 2 \\
\hline Dactylis glomerata & 0 & 4 & 2 & Rumex scutatus & 1 & 0 & 0 \\
\hline Dactylorhiza maculata & 5 & 4 & 3 & Salix appendiculata & 3 & 7 & 15 \\
\hline Daphne mezereum & 19 & 20 & 20 & Salix caprea & 1 & 0 & 5 \\
\hline Deschampsia cespitosa & 5 & 6 & 6 & Salvia glutinosa & 10 & 10 & 11 \\
\hline Deschampsia flexuosa & 0 & 2 & 2 & Sambucus nigra & 1 & 1 & 4 \\
\hline Doronicum austriacum & 1 & 2 & 1 & Sambucus racemosa & 3 & 15 & 17 \\
\hline Dryopteris affinis & 11 & 10 & 15 & Sanicula europaea & 11 & 10 & 10 \\
\hline Dryopteris carthusiana & 9 & 13 & 18 & Saxifraga rotundifolia & 5 & 8 & 9 \\
\hline Dryopteris dilatata & 10 & 9 & 13 & Scabiosa lucida & 1 & 0 & 3 \\
\hline Dryopteris expansa & 0 & 1 & 0 & Scrophularia nodosa & 1 & 2 & 3 \\
\hline Dryopteris filix-mas & 21 & 16 & 21 & Sedum album & 0 & 1 & 2 \\
\hline Dryopteris remota & 0 & 0 & 1 & Senecio abrotanifolius & 3 & 1 & 0 \\
\hline Elymus caninus & 0 & 0 & 2 & Senecio ovatus & 18 & 23 & 23 \\
\hline Epilobium angustifolium & 0 & 0 & 3 & Sesleria albicans & 16 & 14 & 13 \\
\hline Epilobium montanum & 8 & 19 & 20 & Silene dioica & 1 & 4 & 6 \\
\hline Epipactis atrorubens & 5 & 2 & 1 & Silene pusilla & 2 & 2 & 1 \\
\hline Epipactis helleborine & 2 & 0 & 0 & Silene vulgaris & 3 & 1 & 4 \\
\hline Equisetum arvense & 1 & 0 & 0 & Solanum dulcamara & 0 & 3 & 4 \\
\hline Erica herbacea & 6 & 4 & 3 & Soldanella alpina & 2 & 2 & 0 \\
\hline
\end{tabular}


Appendix 4.S5. continued

Anhang 4.S5. Fortsetzung

\begin{tabular}{|c|c|c|c|c|c|c|c|}
\hline Species & Mature & Initial ES & Adv. ES & Species & Mature & Initial ES & Adv. ES \\
\hline Eupatorium cannabinum & 2 & 9 & 11 & Solidago virgaurea & 23 & 23 & 22 \\
\hline Euphorbia amygdaloides & 1 & 0 & 1 & Sorbus aria & 14 & 13 & 11 \\
\hline Euphorbia cyparissias & 5 & 5 & 5 & Sorbus aucuparia & 22 & 23 & 23 \\
\hline Euphrasia picta & 1 & 0 & 1 & Stachys alopecuros & 4 & 3 & 4 \\
\hline Euphrasia salisburgensis & 0 & 0 & 1 & Stachys sylvatica & 0 & 2 & 2 \\
\hline Fagus sylvatica & 12 & 11 & 15 & Stellaria alsine & 0 & 1 & 0 \\
\hline Festuca altissima & 0 & 1 & 0 & Stellaria nemorum & 1 & 0 & 5 \\
\hline Festuca gigantea & 0 & 1 & 5 & Streptopus amplexifolius & 2 & 3 & 3 \\
\hline Festuca rupicaprina & 0 & 0 & 1 & Taxus baccata & 1 & 1 & 0 \\
\hline Fragaria vesca & 21 & 24 & 22 & Teucrium chamaedrys & 1 & 0 & 1 \\
\hline Frangula alnus & 2 & 0 & 1 & Teucrium montanum & 1 & 0 & 0 \\
\hline Fraxinus excelsior & 8 & 8 & 13 & Thalictrum aquilegiifolium & 7 & 5 & 6 \\
\hline Galeobdolon luteum & 17 & 19 & 21 & Thelypteris limbosperma & 6 & 5 & 6 \\
\hline Galeopsis speciosa & 0 & 9 & 6 & Thesium alpinum & 1 & 0 & 1 \\
\hline Galeopsis tetrahit & 0 & 1 & 2 & Thymus praecox & 2 & 0 & 3 \\
\hline Galium album & 8 & 14 & 16 & Thymus pulegioides & 0 & 0 & 2 \\
\hline Galium anisophyllon & 14 & 15 & 15 & Tilia platyphyllos & 1 & 0 & 1 \\
\hline Galium odoratum & 2 & 1 & 3 & Tofieldia calyculata & 4 & 1 & 2 \\
\hline Galium rotundifolium & 6 & 10 & 6 & Trifolium pratense & 2 & 3 & 2 \\
\hline Gentiana asclepiadea & 15 & 14 & 15 & Trifolium repens & 0 & 0 & 1 \\
\hline Gentiana pannonica & 1 & 0 & 1 & Trollius europaeus & 1 & 1 & 3 \\
\hline Gentianella ciliata & 0 & 1 & 0 & Tussilago farfara & 5 & 4 & 8 \\
\hline Geranium robertianum & 7 & 12 & 22 & Ulmus glabra & 4 & 1 & 5 \\
\hline Geranium sylvaticum & 7 & 4 & 3 & Urtica dioica & 3 & 19 & 21 \\
\hline Geum rivale & 1 & 0 & 1 & Vaccinium myrtillus & 18 & 18 & 21 \\
\hline Geum urbanum & 0 & 3 & 0 & Vaccinium vitis-idaea & 5 & 2 & 4 \\
\hline Globularia nudicaulis & 0 & 0 & 1 & Valeriana montana & 4 & 8 & 3 \\
\hline Gnaphalium norvegicum & 0 & 0 & 1 & Valeriana officinalis & 1 & 0 & 1 \\
\hline Gymnadenia odoratissima & 1 & 0 & 1 & Valeriana saxatilis & 1 & 0 & 0 \\
\hline Gymnocarpium dryopteris & 19 & 16 & 21 & Valeriana tripteris & 19 & 22 & 19 \\
\hline Gymnocarpium robertianum & 21 & 20 & 19 & Veratrum album & 5 & 7 & 6 \\
\hline Gypsophila repens & 0 & 0 & 1 & Verbascum thapsus & 0 & 2 & 2 \\
\hline Helleborus niger & 2 & 1 & 2 & Veronica chamaedrys & 6 & 13 & 15 \\
\hline Hepatica nobilis & 6 & 4 & 2 & Veronica officinalis & 4 & 7 & 7 \\
\hline Heracleum austriacum & 4 & 2 & 1 & Veronica serpyllifolia & 0 & 1 & 0 \\
\hline Heracleum sphondylium & 2 & 0 & 1 & Veronica urticifolia & 16 & 19 & 14 \\
\hline Heracleum sphondylium & 0 & 1 & 0 & Vicia sepium & 0 & 0 & 2 \\
\hline Hieracium bifidum & 10 & 12 & 7 & Vincetoxicum hirundinaria & 2 & 0 & 1 \\
\hline Hieracium murorum & 11 & 8 & 9 & Viola biflora & 17 & 15 & 19 \\
\hline Holcus lanatus & 0 & 1 & 0 & Viola reichenbachiana & 0 & 2 & 0 \\
\hline Homogyne alpina & 17 & 14 & 10 & Viola riviniana & 0 & 2 & 0 \\
\hline Hordelymus europaeus & 1 & 2 & 3 & & & & \\
\hline
\end{tabular}


Appendix 4.S6. Species list of wood-inhabiting fungi and their constancy on the12 plots of each of the three successional stages. Mature: mature stage, Initial ES: initial early-seral stage, Adv. ES: advanced early-seral stage. A total of 242 wood-inhabiting fungi species were mapped, with 133 species in the mature stage, 121 species in the initial-early seral stage and 133 species in the advanced early-seral stage.

Anhang 4.S6. Artenliste der totholzbesiedelnden Pilze und deren Stetigkeit auf den je 12 Probeflächen der drei Sukzessionsstadien. Mature: Fichtenaltbestand, Initial ES: beginnende Sukzession, Adv. ES: fortschreitende Sukzession. Insgesamt wurden 242 Arten erfasst mit 133 Arten in den Fichtenaltbeständen, 121 Arten im Stadium der beginnenden Sukzession und 133 Arten im Stadium der fortschreitenden Sukzession.

\begin{tabular}{|c|c|c|c|}
\hline Species name & Mature & Initial ES & Adv. ES \\
\hline Agrarius laevigatus & 1 & 0 & 2 \\
\hline Aleurodiscus amorphus & 0 & 1 & 0 \\
\hline Amphinema byssoides & 6 & 5 & 5 \\
\hline Amylostereum areolatum & 10 & 6 & 4 \\
\hline Antrodia serialis & 1 & 6 & 9 \\
\hline Antrodia xantha & 0 & 0 & 1 \\
\hline Ascocoryne sarcoides & 0 & 1 & 1 \\
\hline Ascocoryne solitaria & 1 & 0 & 0 \\
\hline Athelia decipiens & 4 & 0 & 4 \\
\hline Athelia neuhoffii & 0 & 1 & 0 \\
\hline Athelopsis fusoidea & 1 & 0 & 0 \\
\hline Athelopsis glaucina & 0 & 0 & 1 \\
\hline Athelopsis subinconspicua & 0 & 0 & 2 \\
\hline Auriporia aurulenta & 0 & 0 & 1 \\
\hline Basidiodendron caesiocinereum & 4 & 6 & 4 \\
\hline Basidiodendron deminutum & 1 & 2 & 0 \\
\hline Basidiodendron eyrei & 1 & 0 & 1 \\
\hline Basidioradulum radula & 0 & 1 & 0 \\
\hline Bisporella citrina & 2 & 0 & 0 \\
\hline Boidinia furfuracea & 0 & 1 & 0 \\
\hline Botryobasidium conspersum & 0 & 2 & 4 \\
\hline Botryobasidium intertextum & 1 & 3 & 3 \\
\hline Botryobasidium pruinatum & 0 & 1 & 0 \\
\hline Botryobasidium subcoronatum & 6 & 6 & 6 \\
\hline Botryobasidium vagum & 2 & 2 & 3 \\
\hline Botryohypochnus isabellinus & 1 & 0 & 1 \\
\hline Calocera cornea & 1 & 0 & 0 \\
\hline Calocera furcata & 3 & 0 & 1 \\
\hline Calocera viscosa & 2 & 1 & 1 \\
\hline Camarops tubulina & 0 & 1 & 2 \\
\hline Cantharellus lutescens & 1 & 0 & 0 \\
\hline Ceriporia viridans & 0 & 1 & 0 \\
\hline Ceriporiopsis mucida & 1 & 0 & 0 \\
\hline Chlorociboria aeruginascens & 2 & 0 & 0 \\
\hline Chrysomphalina chrysophylla & 0 & 0 & 1 \\
\hline Cinereomyces lindbladii & 1 & 1 & 2 \\
\hline
\end{tabular}

\begin{tabular}{|c|c|c|c|}
\hline Species name & Mature & Initial ES & Adv. ES \\
\hline Lachnellula abietis & 0 & 3 & 0 \\
\hline Lachnellula occidentalis & 2 & 0 & 0 \\
\hline Lachnellula resinaria & 2 & 0 & 0 \\
\hline Lachnellula subtilissima & 0 & 1 & 0 \\
\hline Lachnum brevipilosum & 3 & 3 & 1 \\
\hline Lasiosphaeria spermoides & 0 & 0 & 1 \\
\hline Lentinellus micheneri & 0 & 0 & 1 \\
\hline Lopharia spadicea & 0 & 1 & 0 \\
\hline Marasmius alliaceus & 1 & 0 & 0 \\
\hline Melanomma pulvis-pyrius & 0 & 0 & 2 \\
\hline Metulodontia nivea & 1 & 0 & 0 \\
\hline Mollisia lividofusca & 1 & 1 & 1 \\
\hline Mollisia olivaceocinerea & 5 & 5 & 6 \\
\hline Multiclavula mucida & 0 & 0 & 1 \\
\hline Mycena cyanorrhiza & 4 & 4 & 2 \\
\hline Mycena epipterygia & 0 & 4 & 1 \\
\hline Mycena galopus & 0 & 0 & 1 \\
\hline Mycena lasiosperma & 1 & 0 & 0 \\
\hline Mycena leptocephala & 2 & 6 & 5 \\
\hline Mycena purpureofusca & 1 & 2 & 0 \\
\hline Mycena renati & 1 & 0 & 0 \\
\hline Mycena rubromarginata & 7 & 8 & 9 \\
\hline Mycena speirea & 0 & 2 & 0 \\
\hline Mycena viridimarginata & 5 & 5 & 2 \\
\hline Nectria fuckeliana & 1 & 1 & 0 \\
\hline Nemania serpens var. serpens & 1 & 0 & 0 \\
\hline Ophiostoma polyporicola & 0 & 0 & 1 \\
\hline Orbilia delicatula & 1 & 3 & 3 \\
\hline Orbilia inflatula & 3 & 5 & 2 \\
\hline Orbilia sarraziniana & 1 & 0 & 0 \\
\hline Peniophora cinerea & 0 & 0 & 1 \\
\hline Peniophora incarnata & 0 & 0 & 1 \\
\hline Peniophora pithya & 1 & 9 & 3 \\
\hline Peniophorella martinii & 0 & 2 & 0 \\
\hline Phanerochaete sordida & 0 & 1 & 1 \\
\hline Phellinus nigrolimitatus & 0 & 0 & 1 \\
\hline
\end{tabular}


Appendix 4.S6. continued

Anhang 4.S6. Fortsetzung

\begin{tabular}{|c|c|c|c|}
\hline Species name & Mature & Initial ES & Adv. ES \\
\hline Claussenomyces prasinulus & 1 & 0 & 1 \\
\hline Clavaria straminea & 1 & 0 & 0 \\
\hline Climacocystis borealis & 1 & 0 & 0 \\
\hline Clitopilus hobsonii & 2 & 1 & 2 \\
\hline Colpoma crispum & 1 & 0 & 0 \\
\hline Conferticium ochraceum & 2 & 0 & 1 \\
\hline Coniophora arida & 0 & 2 & 0 \\
\hline Coniophora olivacea & 2 & 0 & 2 \\
\hline Crepidotus cesatii & 0 & 2 & 2 \\
\hline Cyathicula cyathoidea & 0 & 1 & 0 \\
\hline Cyphella candida & 1 & 0 & 1 \\
\hline Cyphella digitalis & 1 & 0 & 0 \\
\hline Cystolepiota seminuda & 0 & 1 & 0 \\
\hline Dacrymyces capitatus & 3 & 1 & 0 \\
\hline Dacrymyces chrysospermus & 5 & 5 & 2 \\
\hline Dacrymyces stillatus & 6 & 10 & 12 \\
\hline Dacryobolus sudans & 1 & 0 & 0 \\
\hline Dasyscyphus virgineus & 1 & 1 & 0 \\
\hline Datronia mollis & 1 & 0 & 0 \\
\hline Dendrothele acerina & 1 & 0 & 0 \\
\hline Dialonectria epishaeria & 0 & 0 & 1 \\
\hline Diatrype disciformis & 0 & 0 & 1 \\
\hline Diatrype stigma & 0 & 1 & 3 \\
\hline Eichleriella deglubens & 1 & 0 & 0 \\
\hline Entoloma byssisedum & 0 & 1 & 0 \\
\hline Entoloma cyanulum & 0 & 0 & 1 \\
\hline Entoloma lepidissimum & 1 & 0 & 0 \\
\hline Entoloma placidum & 0 & 0 & 1 \\
\hline Entoloma pseudoturci & 0 & 0 & 1 \\
\hline Entoloma pygmaeopapillatum & 0 & 0 & 1 \\
\hline Eutypa maura & 1 & 1 & 0 \\
\hline Exidia glandulosa & 1 & 1 & 0 \\
\hline Exidia pithya & 7 & 10 & 6 \\
\hline Exidia saccharina & 0 & 1 & 1 \\
\hline Exidiopsis calcea & 12 & 8 & 3 \\
\hline Flagelloscypha minutissima & 1 & 3 & 3 \\
\hline Fomes fomentarius & 1 & 0 & 0 \\
\hline Fomitopsis pinicola & 7 & 11 & 12 \\
\hline Fomitopsis rosea & 1 & 4 & 3 \\
\hline Galerina badipes & 0 & 0 & 1 \\
\hline Galerina camerina & 1 & 1 & 1 \\
\hline Galerina hypnorum & 0 & 1 & 0 \\
\hline Galerina vittiformis & 0 & 0 & 1 \\
\hline Gelatoporia pannocincta & 0 & 0 & 1 \\
\hline Gloeocystidiellum clavuligerum & 1 & 0 & 0 \\
\hline
\end{tabular}

\begin{tabular}{|c|c|c|c|}
\hline Species name & Mature & Initial ES & Adv. ES \\
\hline Phellinus viticola & 0 & 0 & 1 \\
\hline Phialina pseudopuberula & 1 & 0 & 0 \\
\hline Phlebia centrifuga & 0 & 4 & 2 \\
\hline Phlebia livida & 0 & 2 & 0 \\
\hline Phlebia segregata & 2 & 0 & 3 \\
\hline Phlebia serialis & 0 & 1 & 0 \\
\hline Phlebia subulata & 0 & 1 & 0 \\
\hline Phlebia tremellosa & 0 & 1 & 0 \\
\hline Phlebiella grisella & 1 & 0 & 0 \\
\hline Phlebiella tulasnelloidea & 0 & 1 & 0 \\
\hline Phlebiella vaga & 2 & 1 & 2 \\
\hline Phlebiopsis gigantea & 0 & 4 & 0 \\
\hline Physisporinus vitreus & 1 & 1 & 2 \\
\hline Phytoconis ericetorum & 0 & 0 & 1 \\
\hline Pleurotus ostreatus & 0 & 2 & 0 \\
\hline Plicaturopsis crispa & 0 & 0 & 1 \\
\hline Pluteus atromarinatus & 0 & 0 & 2 \\
\hline Pluteus hiatulus & 0 & 1 & 0 \\
\hline Pluteus phlebophorus & 0 & 1 & 0 \\
\hline Pluteus podospileus & 0 & 1 & 0 \\
\hline Pluteus umbrosus & 0 & 1 & 0 \\
\hline Polyporus badius & 0 & 0 & 1 \\
\hline Postia caesia & 0 & 4 & 4 \\
\hline Postia undosa & 2 & 1 & 0 \\
\hline Protohydnum piceicola & 0 & 2 & 1 \\
\hline Pseudohydnum gelatinosum & 1 & 0 & 2 \\
\hline Pseudomerulius aureus & 1 & 0 & 1 \\
\hline Pseudotomentella mucidula & 0 & 1 & 0 \\
\hline Resinicium bicolor & 2 & 4 & 1 \\
\hline Resinicium furfuraceum & 1 & 1 & 0 \\
\hline Resupinatus applicatus & 2 & 1 & 2 \\
\hline Rigidoporus sanguinolentus & 0 & 0 & 1 \\
\hline Sarcoporia polyspora & 0 & 1 & 0 \\
\hline Sarea resinae & 2 & 1 & 0 \\
\hline Schizophyllum commune & 1 & 2 & 2 \\
\hline Schizopora paradoxa & 1 & 0 & 0 \\
\hline Scopuloides rimosa & 0 & 0 & 1 \\
\hline Scutellinia umbrorum & 0 & 2 & 0 \\
\hline Sebacina epigaea & 0 & 1 & 0 \\
\hline Sebacina grisea & 0 & 1 & 2 \\
\hline Sidera vulgaris & 1 & 0 & 0 \\
\hline $\begin{array}{l}\text { Simocybe centunculus var. } \\
\text { centunculus }\end{array}$ & 0 & 1 & 0 \\
\hline Simocybe haustellaris & 0 & 1 & 0 \\
\hline Sistotrema brinkmannii & 0 & 0 & 3 \\
\hline Sistotrema diademiferum & 0 & 0 & 1 \\
\hline
\end{tabular}


Appendix 4.S6. continued

Anhang 4.S6. Fortsetzung

\begin{tabular}{|c|c|c|c|}
\hline Species name & Mature & Initial ES & Adv. ES \\
\hline Gloeophyllum abietinum & 2 & 2 & 2 \\
\hline Gloeophyllum odoratum & 0 & 1 & 1 \\
\hline Gloeophyllum sepiarium & 1 & 3 & 6 \\
\hline Gloiothele citrina & 1 & 0 & 0 \\
\hline Gymnopilus bellulus & 1 & 0 & 2 \\
\hline Gymnopilus sapineus & 1 & 1 & 1 \\
\hline Gymnopus androsaceus & 6 & 5 & 2 \\
\hline Gymnopus impudicus & 1 & 0 & 0 \\
\hline Gymnopus perforans & 1 & 0 & 0 \\
\hline Hamatocanthoscypha laricionis & 0 & 1 & 0 \\
\hline Helicogloea farinacea & 1 & 0 & 0 \\
\hline Heterobasidion annosum & 0 & 0 & 1 \\
\hline Hyaloscypha aureliella & 9 & 10 & 11 \\
\hline Hydropisphaera peziza & 0 & 1 & 0 \\
\hline Hydropus marginellus & 0 & 0 & 1 \\
\hline Hymenochaete fuliginosa & 4 & 1 & 1 \\
\hline Hyphoderma argillaceum & 4 & 4 & 3 \\
\hline Hyphoderma involutum & 0 & 0 & 1 \\
\hline Hyphoderma praetermissum & 4 & 2 & 3 \\
\hline Hyphoderma velatum indet. & 1 & 0 & 0 \\
\hline Hyphodermum albocremum & 0 & 0 & 1 \\
\hline Hyphodiscus hymeniophilus & 0 & 2 & 2 \\
\hline Hyphodontia alutacea & 2 & 0 & 1 \\
\hline Hyphodontia alutaria & 3 & 0 & 0 \\
\hline Hyphodontia arguta & 0 & 2 & 2 \\
\hline Hyphodontia aspera & 1 & 1 & 0 \\
\hline Hyphodontia cineracea & 3 & 0 & 0 \\
\hline Hyphodontia crustosa & 1 & 0 & 0 \\
\hline Hyphodontia nespori & 2 & 0 & 1 \\
\hline Hyphodontia pallidula & 2 & 0 & 1 \\
\hline Hyphodontia sambuci & 1 & 1 & 0 \\
\hline Hyphodontia spathulata & 0 & 0 & 2 \\
\hline Hyphodontia subalutacea & 0 & 0 & 1 \\
\hline Hypholoma fasciculare & 1 & 0 & 0 \\
\hline Hypomyces aurantius & 0 & 1 & 0 \\
\hline Hypoxylon fragiforme & 1 & 1 & 1 \\
\hline Hypoxylon fraxinophilum & 0 & 0 & 1 \\
\hline Ischnoderma benzoinum & 0 & 1 & 0 \\
\hline Kretzschmaria deusta & 0 & 1 & 1 \\
\hline Laccaria amethystina & 0 & 0 & 1 \\
\hline
\end{tabular}

\begin{tabular}{|c|c|c|c|}
\hline Species name & Mature & Initial ES & Adv. ES \\
\hline Skeletocutis lilacina & 0 & 0 & 1 \\
\hline Skeletocutis nivea & 0 & 0 & 1 \\
\hline Spongiporus caesius & 1 & 0 & 1 \\
\hline Spongiporus subcaesius & 0 & 0 & 1 \\
\hline Steccherinum ochraceum & 0 & 0 & 1 \\
\hline Stereum sanguinolentum & 6 & 10 & 6 \\
\hline Subulicystidium longisporum & 1 & 0 & 0 \\
\hline Suillosporium cystidiatum & 1 & 1 & 0 \\
\hline Thelephora terrestris & 1 & 0 & 0 \\
\hline Tomentella badia & 0 & 0 & 2 \\
\hline Tomentella bryophila & 1 & 0 & 0 \\
\hline Tomentella cinerascens & 0 & 0 & 1 \\
\hline Tomentella coerulea & 0 & 0 & 1 \\
\hline Tomentella ellisii & 0 & 1 & 0 \\
\hline Tomentella fatrensis & 1 & 0 & 0 \\
\hline Tomentella fibrosa & 1 & 0 & 0 \\
\hline Tomentella galzinii & 1 & 0 & 0 \\
\hline Tomentella lapida & 1 & 0 & 0 \\
\hline Tomentella stuposa & 1 & 0 & 0 \\
\hline Tomentella terrestris & 6 & 0 & 1 \\
\hline Tomentella testaceogilva & 1 & 1 & 0 \\
\hline Trametes hirsuta & 0 & 0 & 2 \\
\hline Trametes versicolor & 0 & 0 & 1 \\
\hline Trechispora confinis & 0 & 0 & 2 \\
\hline Trechispora farinacea & 3 & 1 & 0 \\
\hline Trechispora hymenocystis & 1 & 1 & 1 \\
\hline Trechispora mollusca & 1 & 2 & 1 \\
\hline Trechispora subsphaerospora & 1 & 0 & 0 \\
\hline Tremella encephala & 0 & 1 & 2 \\
\hline Tretomyces lutescens & 1 & 0 & 0 \\
\hline Trichaptum abietinum & 9 & 12 & 8 \\
\hline Tritirachium dependens & 0 & 1 & 0 \\
\hline Tubulicrinis accedens & 0 & 1 & 0 \\
\hline Tubulicrinis borealis & 2 & 1 & 1 \\
\hline Tubulicrinis medius & 0 & 1 & 0 \\
\hline Tubulicrinis subulatus & 1 & 0 & 0 \\
\hline Tulasnella pinicola & 0 & 0 & 1 \\
\hline Vararia ochroleuca & 1 & 0 & 0 \\
\hline Xeromphalina campanella & 1 & 0 & 0 \\
\hline Xylaria longipes & 4 & 4 & 0 \\
\hline
\end{tabular}


Appendix 4.S7. Species list of saproxylic beetles and their constancy on the 12 plots of each of the three successional stages. Mature: mature stage, Initial ES: initial early-seral stage, Adv. ES: advanced early-seral stage. A total of 137 saproxylic beetle species were mapped, with 67 species in the mature stage, 87 species in the initial-early seral stage and 75 species in the advanced early-seral stage.

Anhang 4.S7. Artenliste der totholzbesiedelnden Käfer und deren Stetigkeit auf den je 12 Probeflächen der drei Sukzessionsstadien. Mature: Fichtenaltbestand, Initial ES: beginnende Sukzession, Adv. ES: fortschreitende Sukzession. Insgesamt wurden 137 Arten erfasst mit 67 Arten in den Fichtenaltbeständen, 87 Arten im Stadium der beginnenden Sukzession und 75 Arten im Stadium der fortschreitenden Sukzession.

\begin{tabular}{|c|c|c|c|c|c|c|c|}
\hline Species & Mature & Initial ES & Adv. ES & Species & Mature & Initial ES & Adv. ES \\
\hline Acmaeops septentrionis & 0 & 0 & 1 & Hylobius piceus & 3 & 0 & 0 \\
\hline Acrulia inflata & 1 & 2 & 0 & Hylurgops glabratus & 6 & 2 & 0 \\
\hline Agathidium nigripenne & 2 & 8 & 1 & Hylurgops palliatus & 2 & 4 & 0 \\
\hline Alosterna tabacicolor & 2 & 1 & 4 & Hypoganus inunctus & 0 & 0 & 1 \\
\hline Ampedus aethiops & 0 & 1 & 3 & Ips typographus & 2 & 2 & 1 \\
\hline Ampedus auripes & 1 & 1 & 0 & Leptophloeus alternans & 0 & 1 & 1 \\
\hline Ampedus balteatus & 0 & 1 & 0 & Leptura maculata & 0 & 0 & 1 \\
\hline Ampedus erythrogonus & 6 & 2 & 2 & Leptusa pulchella & 1 & 4 & 3 \\
\hline Ampedus nigrinus & 2 & 2 & 9 & Liodopria serricornis & 0 & 1 & 0 \\
\hline Ampedus sanguinolentus & 0 & 0 & 1 & Lopherus rubens & 0 & 1 & 1 \\
\hline Anaspis ruficollis & 0 & 1 & 1 & Magdalis nitida & 0 & 3 & 0 \\
\hline Anaspis rufilabris & 5 & 8 & 8 & Malthodes alpicola & 0 & 1 & 0 \\
\hline Anastrangalia sanguinolenta & 1 & 1 & 4 & Megatoma undata & 0 & 0 & 1 \\
\hline Anisotoma castanea & 0 & 1 & 1 & Melanotus castanipes & 4 & 2 & 3 \\
\hline Anisotoma orbicularis & 0 & 0 & 1 & Micrambe abietis & 1 & 0 & 0 \\
\hline Anobium emarginatum & 1 & 1 & 1 & Molorchus minor & 0 & 1 & 2 \\
\hline Anobium pertinax & 0 & 1 & 0 & Mordellistena humeralis & 0 & 0 & 1 \\
\hline Anostirus purpureus & 0 & 0 & 1 & Mordellistena variegata & 0 & 1 & 0 \\
\hline Anthaxia quadripunctata & 0 & 2 & 0 & Mycetina cruciata & 4 & 3 & 5 \\
\hline Anthribus albinus & 0 & 0 & 1 & Nemosoma elongatum & 0 & 3 & 0 \\
\hline Aplocnemus impressus & 1 & 1 & 0 & Nudobius lentus & 0 & 1 & 0 \\
\hline Aplocnemus tarsalis & 0 & 0 & 1 & Obrium brunneum & 1 & 0 & 1 \\
\hline Atheta picipes & 1 & 0 & 0 & Ochina ptinoides & 1 & 0 & 0 \\
\hline Atrecus affinis & 0 & 0 & 2 & Orchesia undulata & 1 & 0 & 0 \\
\hline Bolitochara lucida & 0 & 0 & 1 & Ostoma ferruginea & 1 & 1 & 2 \\
\hline Callidium violaceum & 1 & 1 & 0 & Oxymirus cursor & 0 & 1 & 0 \\
\hline Cetonia aurata & 0 & 0 & 1 & Pachyta quadrimaculata & 0 & 0 & 1 \\
\hline Chrysanthia nigricornis & 0 & 0 & 2 & Pidonia lurida & 1 & 2 & 7 \\
\hline Chrysanthia viridissima & 0 & 1 & 0 & Pissodes harcyniae & 0 & 1 & 0 \\
\hline Cis dentatus & 2 & 2 & 2 & Pityogenes bistridentatus & 0 & 1 & 0 \\
\hline Cis lineatocribratus & 1 & 0 & 0 & Pityogenes chalcographus & 2 & 5 & 1 \\
\hline Cis nitidus & 0 & 0 & 1 & Pityophagus ferrugineus & 1 & 3 & 0 \\
\hline Cis punctulatus & 1 & 0 & 0 & Pityophthorus pityographus & 0 & 2 & 2 \\
\hline Corticaria abietorum & 1 & 0 & 0 & Platycerus caprea & 1 & 0 & 0 \\
\hline
\end{tabular}


Appendix 4.S7. continued

Anhang 4.S7. Fortsetzung

\begin{tabular}{|c|c|c|c|c|c|c|c|}
\hline Species & Mature & Initial ES & Adv. ES & Species & Mature & Initial ES & Adv. ES \\
\hline Corymbia rubra & 0 & 2 & 2 & Platycerus caraboides & 1 & 2 & 0 \\
\hline Cryphalus intermedius & 0 & 1 & 0 & Platycis minutus & 2 & 1 & 2 \\
\hline Cryphalus piceae & 0 & 1 & 0 & Plectophloeus fischeri & 0 & 1 & 0 \\
\hline Cryptophagus cylindrus & 1 & 0 & 0 & Polygraphus poligraphus & 1 & 2 & 2 \\
\hline Crypturgus cinereus & 0 & 0 & 1 & Prostomis mandibularis & 1 & 0 & 0 \\
\hline Crypturgus hispidulus & 0 & 2 & 0 & Pseudocistela ceramboides & 0 & 0 & 1 \\
\hline Curtimorda maculosa & 0 & 0 & 1 & Pteryngium crenatum & 0 & 0 & 1 \\
\hline Cychramus variegatus & 1 & 0 & 0 & Ptilinus pectinicornis & 1 & 0 & 0 \\
\hline Danosoma fasciatus & 0 & 0 & 1 & Quedius plagiatus & 2 & 1 & 2 \\
\hline Dasytes niger & 0 & 0 & 2 & Quedius xanthopus & 4 & 7 & 2 \\
\hline Dasytes obscurus & 0 & 2 & 3 & Rhagium inquisitor & 0 & 0 & 1 \\
\hline Dasytes plumbeus & 2 & 6 & 6 & Rhagium mordax & 0 & 1 & 0 \\
\hline Denticollis linearis & 1 & 2 & 4 & Rhizophagus dispar & 0 & 6 & 1 \\
\hline Denticollis rubens & 1 & 1 & 1 & Rhizophagus ferrugineus & 0 & 4 & 2 \\
\hline Diacanthous undulatus & 0 & 0 & 1 & Rhizophagus grandis & 0 & 1 & 0 \\
\hline Dictyopterus aurora & 2 & 3 & 0 & Salpingus ruficollis & 1 & 1 & 0 \\
\hline Dirhagus lepidus & 1 & 0 & 0 & Saphanus piceus & 0 & 1 & 0 \\
\hline Dorcatoma punctulata & 0 & 0 & 2 & Serropalpus barbatus & 1 & 0 & 0 \\
\hline Dryocoetes autographus & 12 & 12 & 8 & Sphaerites glabratus & 0 & 2 & 0 \\
\hline Epuraea angustula & 1 & 2 & 1 & Stenurella melanura & 2 & 1 & 2 \\
\hline Epuraea boreella & 1 & 0 & 1 & Stephostethus alternans & 1 & 0 & 0 \\
\hline Epuraea longula & 0 & 1 & 0 & Stephostethus rugicollis & 1 & 0 & 0 \\
\hline Epuraea marseuli & 1 & 0 & 0 & Tetropium castaneum & 3 & 4 & 1 \\
\hline Epuraea neglecta & 0 & 1 & 0 & Thanasimus formicarius & 0 & 2 & 1 \\
\hline Epuraea oblonga & 1 & 0 & 0 & Thanasimus pectoralis & 2 & 4 & 0 \\
\hline Epuraea pallescens & 0 & 0 & 1 & Tillus elongatus & 1 & 0 & 0 \\
\hline Epuraea pygmaea & 6 & 4 & 2 & Trachodes hispidus & 0 & 3 & 1 \\
\hline Ernobius mollis & 0 & 2 & 0 & Trichius zonatus & 0 & 0 & 1 \\
\hline Evodinus clathratus & 0 & 1 & 1 & Xylechinus pilosus & 1 & 1 & 0 \\
\hline Gaurotes virginea & 0 & 0 & 3 & Xylita laevigata & 0 & 4 & 2 \\
\hline Glischrochilus quadripunctatus & 0 & 2 & 0 & Xylita livida & 2 & 3 & 0 \\
\hline Hedobia imperialis & 1 & 2 & 0 & Xyloterus domesticus & 0 & 1 & 0 \\
\hline Hylastes cunicularius & 11 & 12 & 9 & Xyloterus lineatus & 6 & 8 & 2 \\
\hline Hylecoetus dermestoides & 0 & 1 & 1 & Xyloterus signatus & 2 & 4 & 0 \\
\hline Hylobius abietis & 1 & 1 & 0 & & & & \\
\hline
\end{tabular}



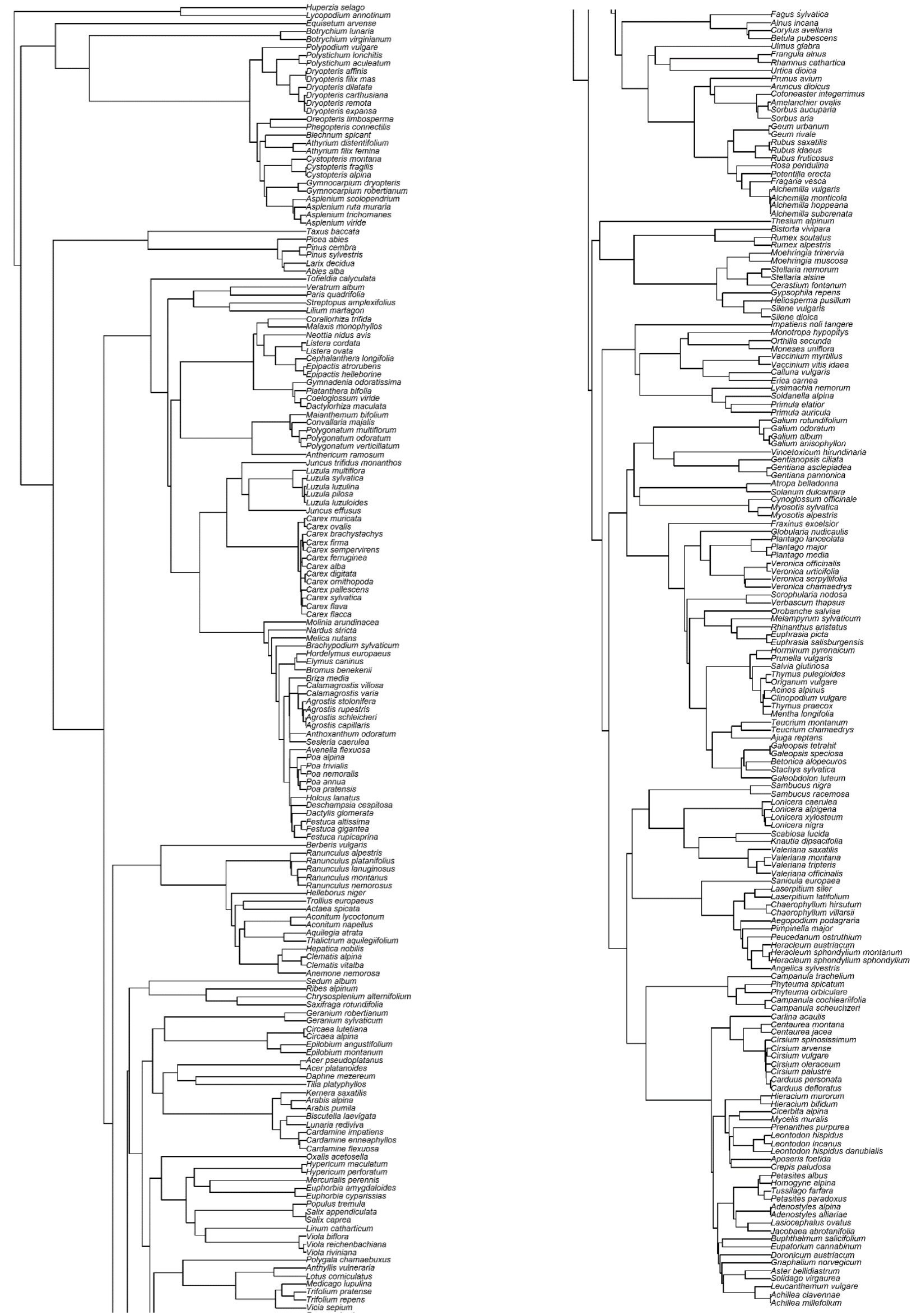

Appendix 4.58. Community phylogeny of vascular plants.

Anhang 4.S8. Phylogenie der Artengemeinschaft der Gefäßpflanzen. 


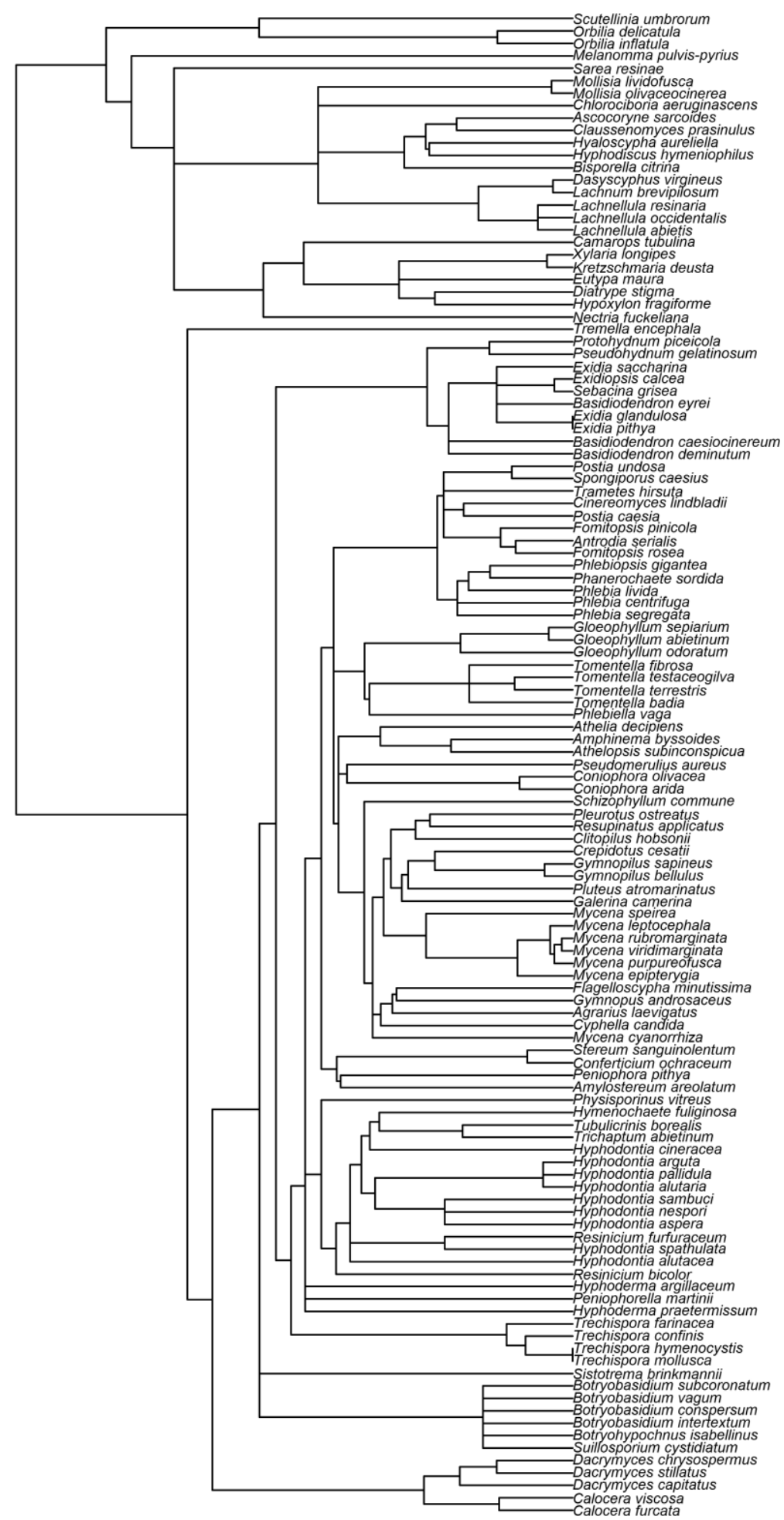

Appendix 4.59. Community phylogeny of wood-inhabiting fungi, excluding singletons.

Anhang 4.S9. Phylogenie der Artengemeinschaft der totholzbesiedelnden Pilze, exklusive jener Arten mit nur einem Fund innerhalb der Studie (singletons). 


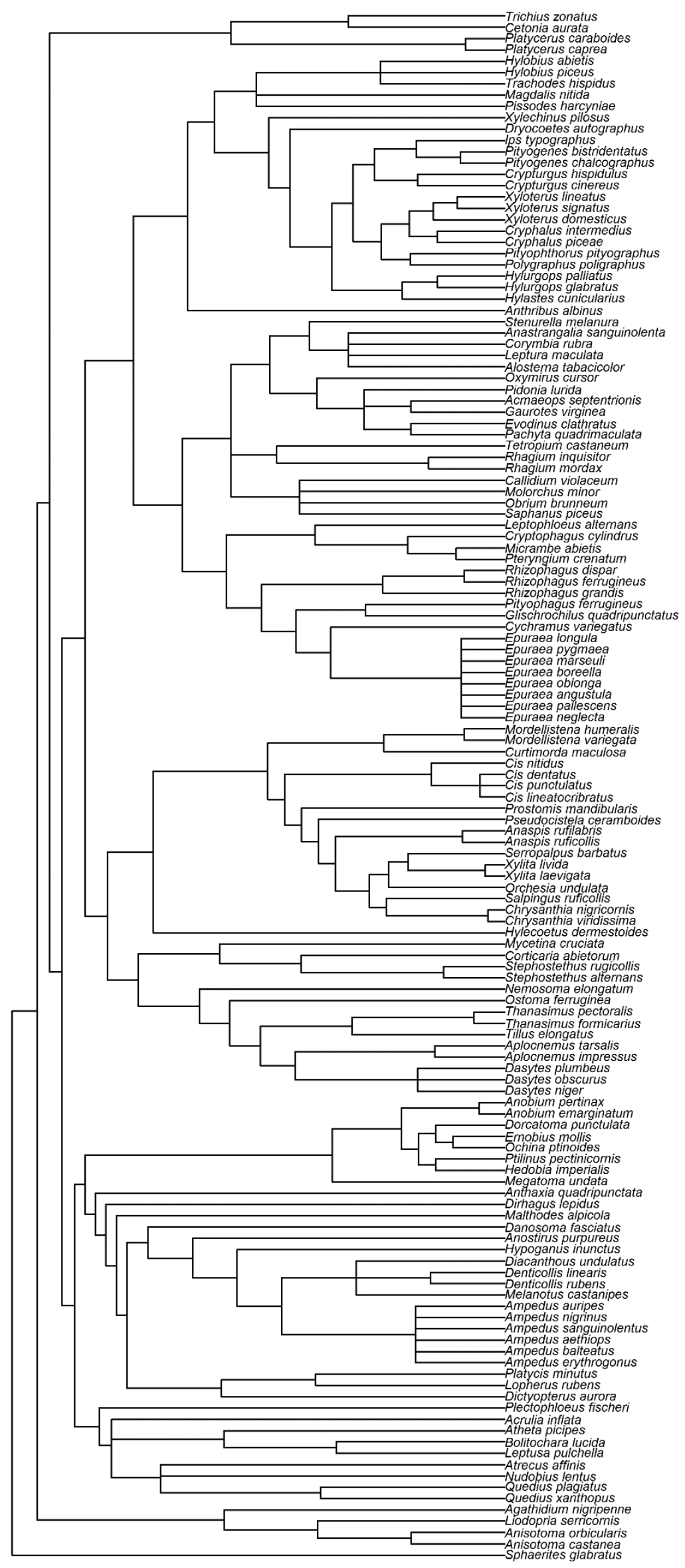

Appendix 4.S10. Community phylogeny of saproxylic beetles.

Anhang 4.S10. Phylogenie der Artengemeinschaft der totholzbesiedelnden Käfer. 
Appendix 4.S11. Observed and estimated species numbers ( \pm standard error) of vascular plants, woodinhabiting fungi and saproxylic beetles within single successional stages and combined for all three successional stages. Mature: mature spruce forest, Initial ES: initial early-seral stage, Adv. ES: advanced earlyseral stage. The estimators are calculated following Chao: Chao (1987), first order Jackknife and Bootstrap: Smith \& van Belle (1984).

Anhang 4.S11. Beobachtete und geschätzte Artenzahlen ( \pm Standardfehler) von Gefäßpflanzen totholzbesiedelnden Pilzen und totholzbesiedelnden Käfern der einzelnen Sukzessionsstadien und kombiniert für die gesamte Artengemeinschaft aller drei Stadien. Mature: Fichtenaltbestand, Initial ES: beginnende Sukzession, Adv. ES: fortschreitende Sukzession. Die Schätzwerte wurden entsprechend folgender Methoden berechnet: Chao: Chao (1987), Jackknife 1. Ordnung und Bootstrap: Smith and van Belle (1984).

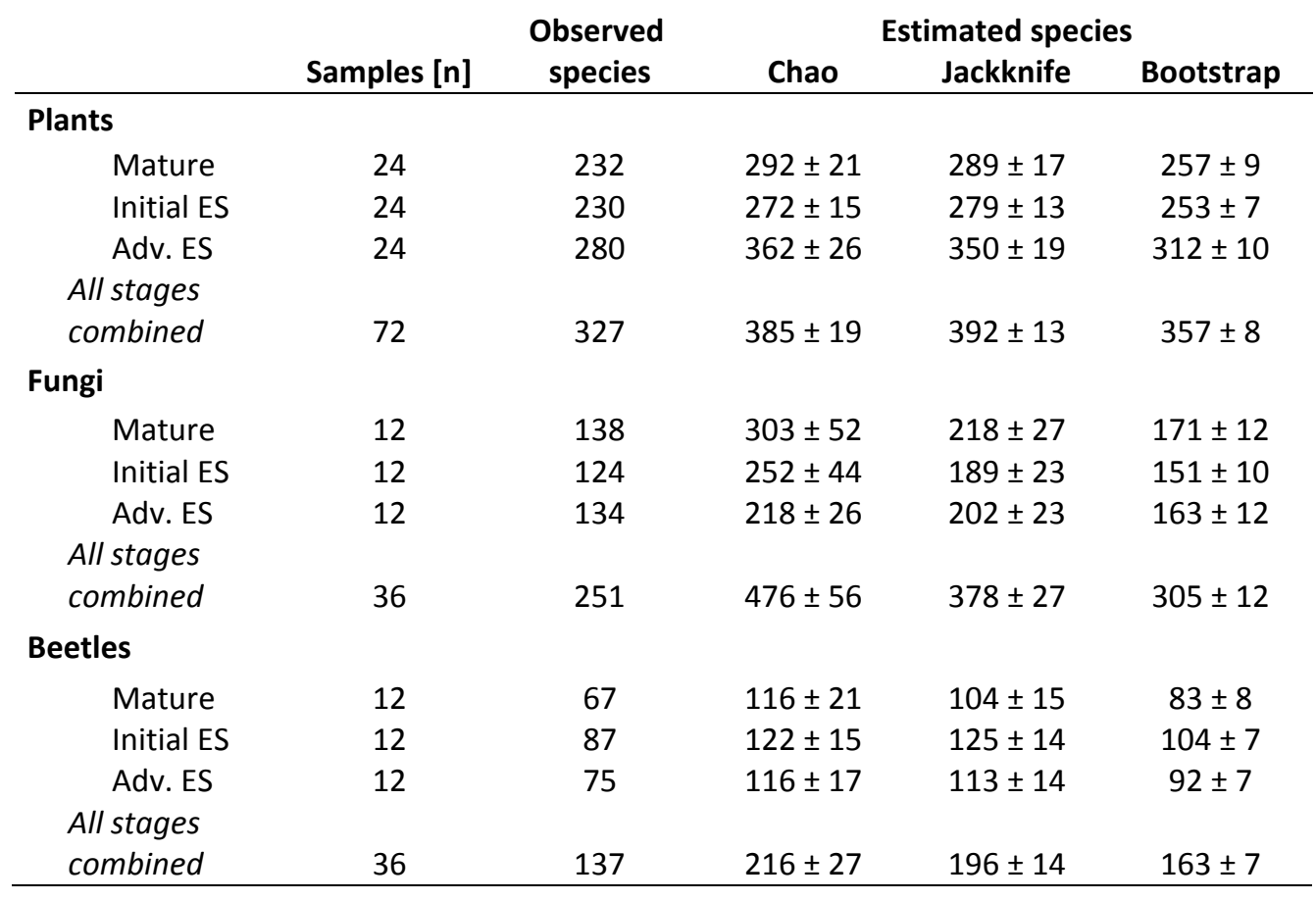




\section{References Appendices S1-S11}

Bässler, C., Müller, J., Cadotte, M.W., Heibl, C., Bradtka, J.H., Thorn, S. \& Halbwachs, H. 2015. Functional response of lignicolous fungal guilds to bark beetle deforestation. Ecological Indicators.

Benson, D.A., Cavanaugh, M., Clark, K., Karsch-Mizrachi, I., Lipman, D.J., Ostell, J. \& Sayers, E.W. 2013. GenBank. Nucleic Acids Research 41: D36-D42.

Bernhardt-Römermann, M., Römermann, C., Nuske, R., Parth, A., Klotz, S., Schmidt, W. \& Stadler, J. 2008. On the identification of the most suitable traits for plant functional trait analyses. Oikos 117: 1533-1541.

Britton, T., Anderson, C., Jaquet, D., Lundqvist, S. \& Bremer, K. 2007. Estimating divergence times in large phylogenetic trees. Systematic Biology 56 (5): 741-752.

Castresana, J. 2000. Selection of conserved blocks from multiple alignments for their use in phylogenetic analysis. Molecular biology and evolution 17 (4): 540-552.

Chao, A. 1987. Estimating the population size for capture-recapture data with unequal catchability. Biometrics 43: 783-791.

Fitter, A.H. \& Peat, H.J. 1994. The Ecological Flora Database. The Journal of Ecology 82 (2): 415.

Gossner, M.M., Lachat, T., Brunet, J., Isacsson, G., Bouget, C., Brustel, H., Brandl, R., Weisser, W. \& Müller, J. 2013. Current Near-to-Nature Forest Management Effects on Functional Trait Composition of Saproxylic Beetles in Beech Forests. Conservation Biology 27 (3): 605-614.

Hintze, C., Heydel, F., Hoppe, C., Cunze, S., König, A. \& Tackenberg, O. 2013. D²: The Dispersal and Diaspore Database - Baseline data and statistics on seed dispersal. Perspectives in Plant Ecology, Evolution and Systematics 15 (3): 180-192.

Jäger, E.J. \& Werner, K. 2005. Rothmaler. Exkursionsflora von Deutschland Gefäßpflanzen: Kritischer Band. Spektrum, Heidelberg, Berlin.

Katoh, K., Misawa, K., Kuma, K. \& Miyata, T. 2002. MAFFT: a novel method for rapid multiple sequence alignment based on fast Fourier transform. Nucleic Acids Research 30 (14): 3059-3066.

Kattge, J., Diaz, S., Lavorel, S., Prentice, I.C., Leadley, P., Bönisch, G., Westoby, M., Reich, P.B., Wright, I.J., (...), Wirth, C. 2011. TRY - a global database of plant traits. Global Change Biology 17 (9): 2905-2935.

Kleyer, M., Bekker, R.M., Knevel, I.C., Bakker, J.P., Thompson, K., Sonnenschein, M., Poschlod, P., van Groenendael, J.M., Klimeš, L., (...), Peco, B. 2008. The LEDA Traitbase: a database of life-history traits of the Northwest European flora. Journal of Ecology 96 (6): 1266-1274.

Klimešová, J. \& de Bello, F. 2009. CLO-PLA: the database of clonal and bud bank traits of Central European flora. Journal of Vegetation Science 20 (3): 511-516.

Klotz, S., Kühn, I. \& Durka, W. 2002. BIOLFLOR - Eine Datenbank mit biologisch-ökologischen Merkmalen zur Flora von Deutschland. BfN Schriftenreihe für Vegetationskunde 38: 1-334.

Miller, M.A., Pfeiffer, W. \& Schwartz, T. 2010. Creating the CIPRES Science Gateway for inference of large phylogenetic trees. Proceedings of the Gateway Computing Environments Workshop (GCE), 14 Nov. 2010, New Orleans, US. 
Miller, M.A., Pfeiffer, W. \& Schwartz, T. 2011. The cipres science gateway: a community resource for phylogenetic analyses. Proceedings of the 2011 TeraGrid Conference: Extreme Digital Discovery, Article No. 41. New York, US.

Nagy, L.G., Kocsubé, S., Csanádi, Z., Kovács, G.M., Petkovits, T., Vágvölgyi \& C., Papp, T. 2012. Re-Mind the Gap! Insertion - Deletion Data Reveal Neglected Phylogenetic Potential of the Nuclear Ribosomal Internal Transcribed Spacer (ITS) of Fungi. PLOS ONE 7 (11): e49794.

Norros, V. 2013. Measuring and modelling airborne dispersal in wood decay fungi. Ph.D thesis, Finish school of Wildlife Biology, Conservation and Management, University of Helsinki, Fl.

Poschlod, P., Kleyer, M., Jackel, A.-K., Dannemann, A. \& Tackenberg, O. 2003. BIOPOP - A database of plant traits and internet application for nature conservation. Folia Geobotanica 38: 263-271.

Prach, K. \& Pyšek, P. 1999. How do species dominating in succession differ from others? Journal of Vegetation Science. 10 (3): 383-392.

Royal Botanic Gardens Kew 2015. Seed Information Database (SID) Version 7.1. Online: http://data.kew.org/sid/.

Schulze, E.-D., Beck, E. \& Müller-Hohenstein, K. 2002. Pflanzenökologie. Spektrum Akademischer Verlag, Heidelberg, D.

Seibold, S., Brandl, R., Buse, J., Hothorn, T., Schmidl, J., Thorn, S. \& Müller, J. 2015. Association of extinction risk of saproxylic beetles with ecological degradation of forests in Europe. Conservation Biology 29: 382-390.

Smith, S.A., Beaulieu, J.M. \& Donoghue, M.J. 2009. Megaphylogeny approach for comparative biology: an alternative to supertree and supermatrix approaches. BMC Evolutionary Biology 9: 37.

Smith, S.A. \& Dunn, C.W. 2008. Phyutility: a phyloinformatic tool for trees, alignments, and molecular data. Bioinformatics 24: 715-716. DOI: 10.1093/bioinformatics/btm619.

Smith, E.P. \& van Belle, G. 1984. Nonparametric estimation of species richness. Biometrics 40: 119-129.

Stamatakis, A., Hoover, P. \& Rougemont, J. 2008. A rapid bootstrap algorithm for the RAxML web servers. Systematic Biology 57:758-771. DOI: 10.1080/10635150802429642.

Talavera, G. \& Castresana, J. 2007. Improvement of phylogenies after removing divergent and ambiguously aligned blocks from protein sequence alignments. Systematic Biology 56 (4): 564-577.

Winter, M.-B., Ammer, C., Baier, R., Donato, D.C., Seibold, S. \& Müller, J. 2015. Multi-taxon alpha diversity following bark beetle disturbance: Evaluating multi-decade persistence of a diverse early-seral phase. Forest Ecology and Management 338: 32-45.

Wisskirchen, R. \& Haeupler, H. 1998. Standardliste der Farn- und Blütenpflanzen Deutschlands. Ulmer, Stuttgart, D. 


\section{Kapitel 5}

\section{Einfluss von Befallsflächengröße, Flächenräumung und Pflanzung auf Verjüngung und Artenvielfalt}

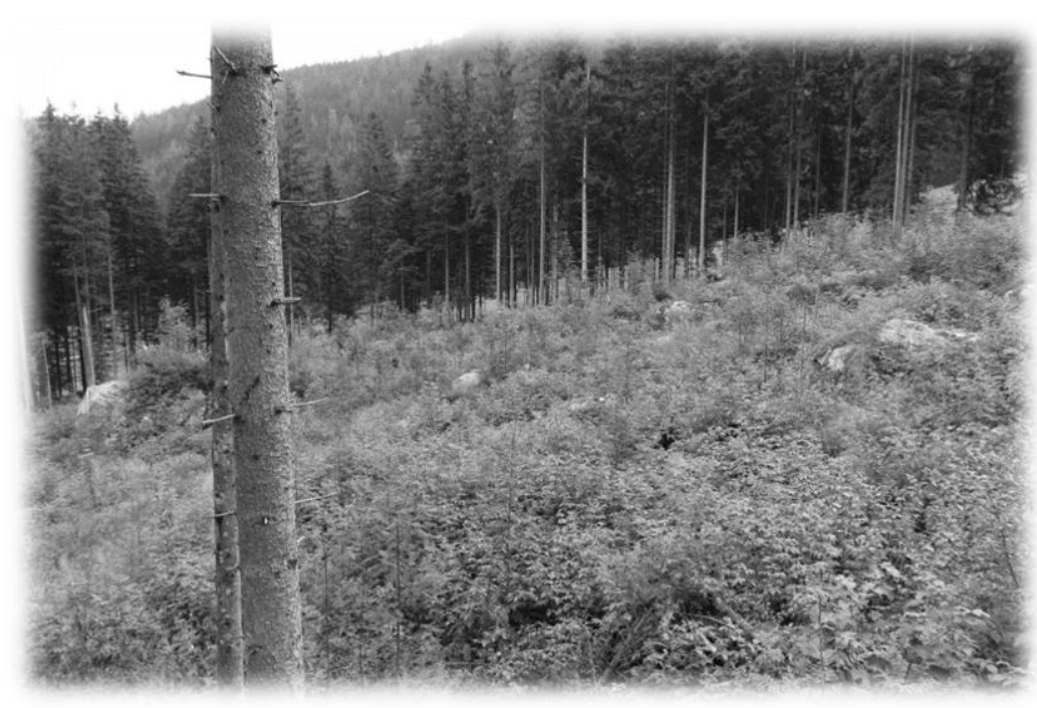

Geräumte und mit gepflanzten Europäischen Buchen und Weißtannen angereicherte Borkenkäfer-

Befallsfläche im Schapbachboden (Foto: H. Maltan). 


\section{Einfluss der Flächenausdehnung des Borkenkäferbefalls auf die Verjüngung in der beginnenden Sukzession}

\section{Standort}

Humus

Bei der Auswertung von insgesamt 448 Humusprofilen auf den Probeflächen der Borkenkäferbefallsflächen $>1$ ha und $<1$ ha ließen sich bei der Mächtigkeit der Humusauflagen keine signifikanten Unterschiede zwischen den einzelnen Positionen nachweisen. Es waren zum Zeitpunkt der Aufnahmen weder Unterschiede zwischen den einzelnen Positionen der großen Befallsflächen, noch zwischen den Probeflächen der großen und der kleinen Befallsflächen zu beobachten (Abb. 5.1 und 5.2). Sowohl auf den großen, als auch auf den kleinen Befallsflächen war überwiegend Tangelhumus zu finden. Auch L-Mull, F-Mull, mullartiger Moder und typischer Moder wurden in ähnlichen Anteilen auf den Probeflächen erfasst.

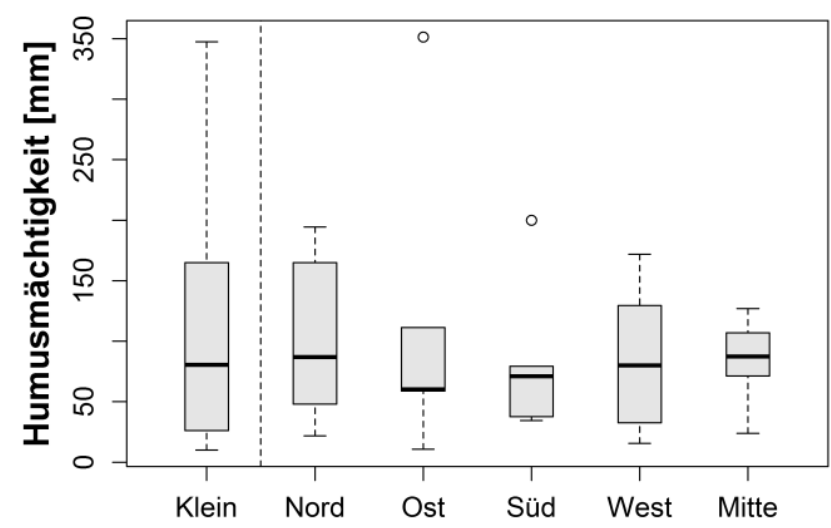

Abb. 5.1 Mittlere Humusmächtigkeiten auf den kleinen Befallsflächen und den verschiedenen Positionen innerhalb der großen Befallsflächen. Es bestehen keine signifikanten Unterschiede zwischen den einzelnen Positionen und Befallsflächengrößen.

Abb. 5.1 Mean thickness of humus layer [mm] on small gaps compared to different locations within large gaps. There are no significant differences; neither among the locations nor among small and large gaps.

\section{Strahlung}

Die Probeflächen am Südrand und in der Mitte der großen Befallsflächen wiesen tendenziell den größten Anteil an direkter Strahlung auf (DSF, $1 \mathrm{~m}$ über Grund, Abb. 5.3). Statistisch war jedoch weder zwischen den einzelnen Positionen innerhalb der großen Befallsflächen noch zwischen den Probeflächen der großen und der kleinen Befallsflächen ein signifikanter Unterschied feststellbar. 

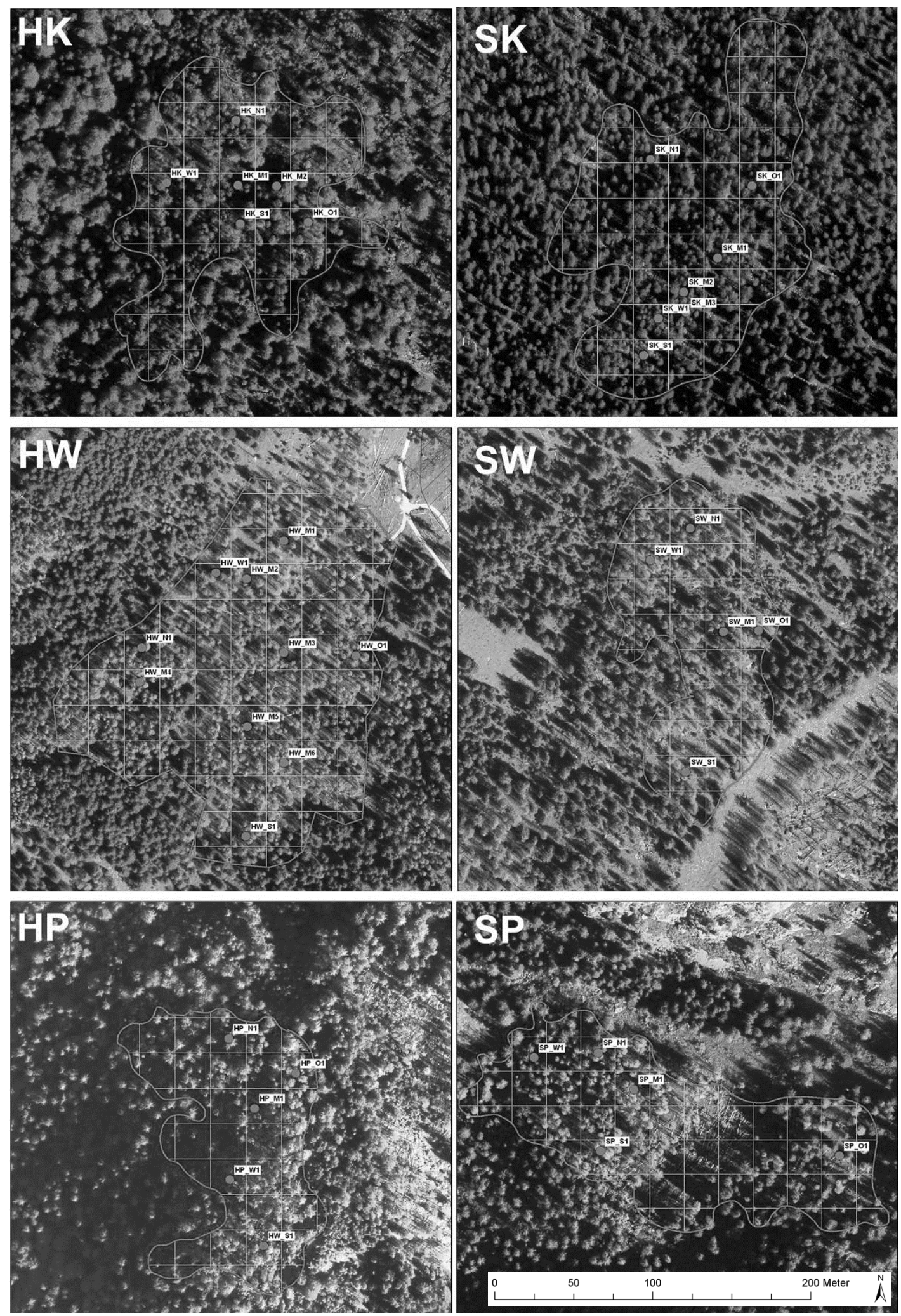

Abb. 5.2 Digitalisierte Borkenkäfer-Befallsflächen > 1 ha Flächenausdehnung mit Lage des Stichprobenrasters und der Mittelpunkte der 38 durch statifizierte Zufallsauswahl ausgewählten Probeflächen über dem CIRLuftbild von 2012. Wesentliche Informationen zu den Probeflächen sind in Tabelle 1.5 hinterlegt.

Fig. 5.2 Digitalized gaps $>1$ ha on CIR aerial image of 2012, position of inventory grid and position of the 38 study plots selected by stratified random sampling. Relevant information on study plots is given in Table 1.5. 


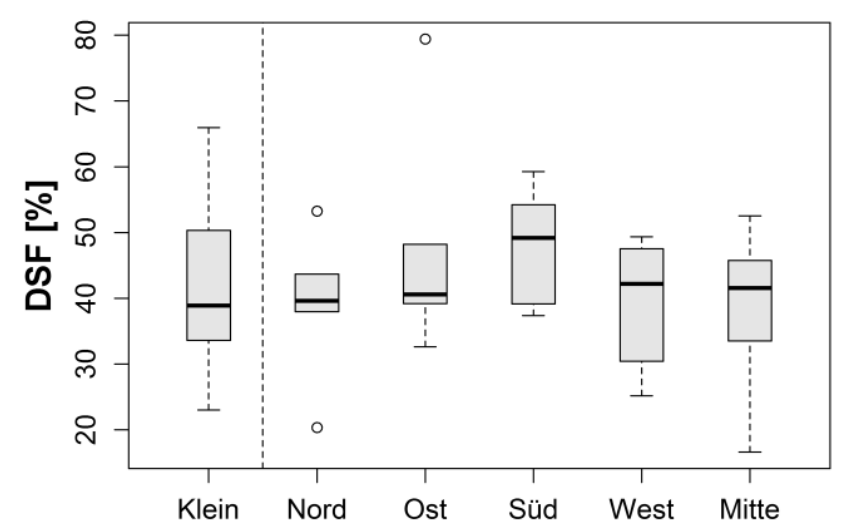

Abb. 5.3 Mittlere Anteile an direkter Strahlung (DSF) $1 \mathrm{~m}$ über dem Waldboden auf den kleinen Befallsflächen und den verschiedenen Positionen innerhalb der großen Befallsflächen. Es bestehen keine signifikanten Unterschiede zwischen den einzelnen Positionen und Befallsflächengrößen.

Fig. 5.3 Mean ratio of direct radiation (DSF) $1 \mathrm{~m}$ above ground on small gaps compared to different locations within large gaps. There are no significant differences; neither among the locations nor among small and large gaps.

\section{Samenverfügbarkeit}

Für die Baumart Fichte war auf 39 \% der Probeflächen in den kleinen Borkenkäfer-Befallsflächen ein überlebender Altbaum als Samenbaum direkt auf der Probefläche zu finden (Tabelle 5.1). Bei den restlichen Probeflächen der kleinen Borkenkäfer-Befallsflächen betrug die Distanz zum nächsten lebenden potentiellen Fichten-Samenbaum weniger als $50 \mathrm{~m}$. Bei den großen Befallsflächen waren die nächsten Fichten-Samenbäume zu 87 \% innerhalb eines $50 \mathrm{~m}$ Radius um die Probeflächen zu finden. Die mittleren Entfernungsdistanzen lagen bei $14 \mathrm{~m}$ auf den kleinen Befallsflächen und bei 24 $\mathrm{m}$ auf den großen Befallsflächen. Auf einzelnen Probeflächen, hauptsächlich auf den Mittelpositionen der großen Störungsflächen, waren die nächsten Fichten-Samenbäume weiter als 50 m entfernt.

Tabelle 5.1 Anteil der Störungsflächen mit Samenbäumen der Gemeinen Fichte in verschiedenen Entfernungsklassen und mittlere Entfernungen zum nächsten Fichten-Samenbaum in kleinen und großen Störungsflächen.

Table 5.1 Ratio of gaps with spruce seed trees in different distance classes and mean distances to next spruce seed tree, in small and large gaps.

\begin{tabular}{rcc} 
& \multicolumn{2}{c}{ Störungsfläche } \\
Entfernung & $<1$ ha & $>1$ ha \\
\hline$<12,6 \mathrm{~m}$ & $39 \%$ & $21 \%$ \\
$12,6-50 \mathrm{~m}$ & $61 \%$ & $66 \%$ \\
$50-100 \mathrm{~m}$ & $0 \%$ & $13 \%$ \\
\hline Mittelwert & $14 \mathrm{~m}$ & $24 \mathrm{~m}$
\end{tabular}


$\mathrm{Da}$, abgesehen von der Fichte, bei keiner weiteren Baumart mit einer wesentlichen direkten Veränderung der Samenzufuhr durch den Borkenkäferbefall zu rechnen ist, wurden sie in diesem Kapitel nicht berücksichtigt. Für den Gesamtkontext der Verjüngungsdynamik wurden diese Baumarten auf den kleinen Befallsflächen in Kapitel 2 diskutiert.

\section{Verjüngung}

\section{Jungwuchsdichte}

Die Jungwuchsdichte wies in der montan/hochmontanen Lage weder signifikante Unterschiede zwischen den einzelnen Positionen der großen Befallsflächen auf, noch zwischen diesen und den kleinen Befallsflächen (Abb. 5.4). Auch in subalpiner Lage unterschieden sich lediglich die Jungwuchsdichten für die Fichte zwischen den Probeflächen am Südrand der großen Befallsflächen signifikant von den Probeflächen in den kleinen Befallsflächen (Tabelle 5.2).
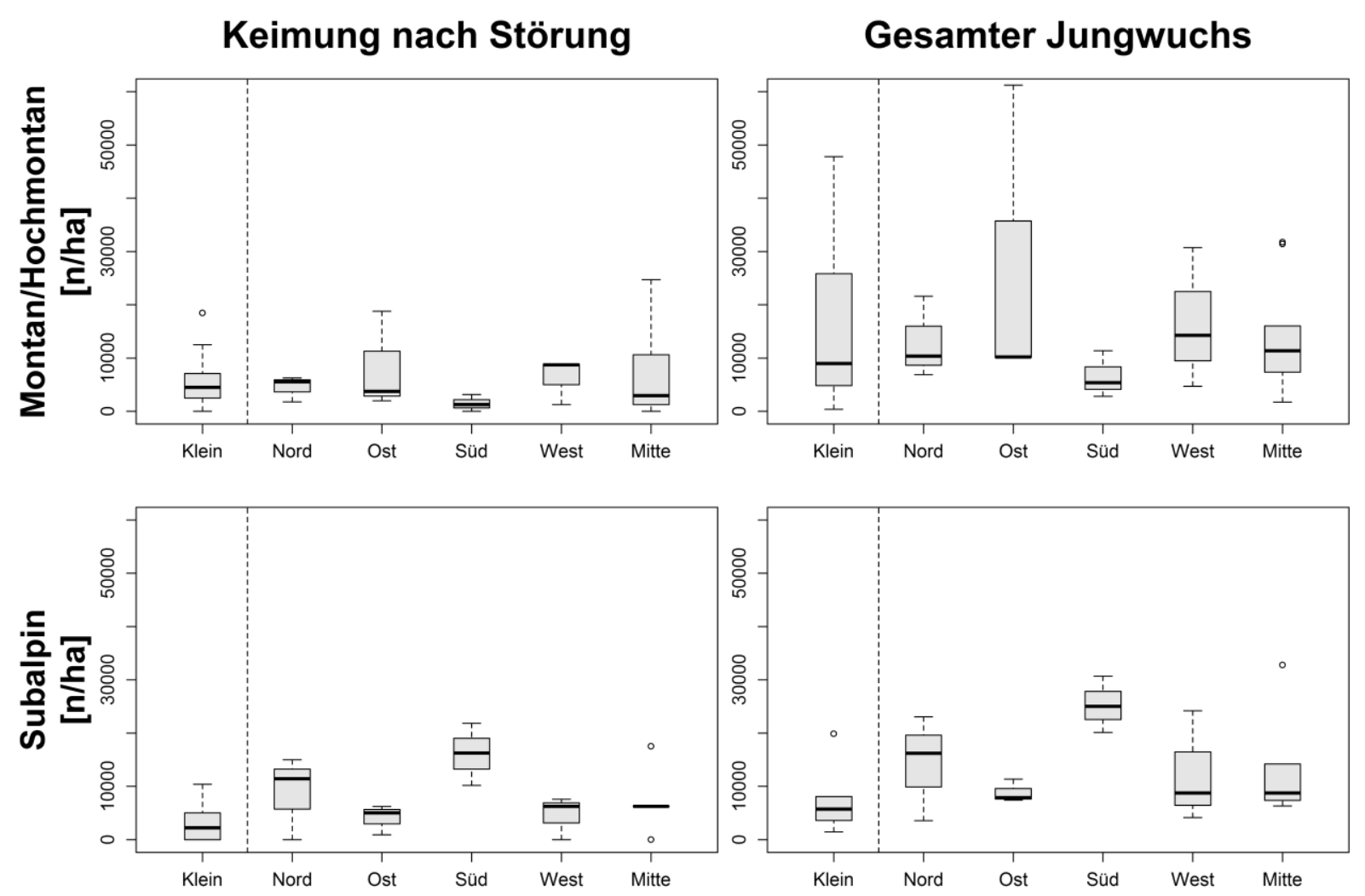

Abb. 5.4 Jungwuchsdichten in montan/hochmontaner und subalpiner Lage der nach dem Störungsereignis gekeimten Individuen und des gesamten Jungwuchses (0 $-200 \mathrm{~cm}$ Höhe) in den einzelnen Positionen. Es bestehen keine signifikanten Unterschiede zwischen den einzelnen Positionen und Befallsflächengrößen.

Fig. 5.4 Regeneration densities in montane/high montane and subalpine elevations differentiated for those individuals that germinated after the disturbance event (left graph) and for all individuals (0 $-200 \mathrm{~cm}$ height, right graph) on small gaps compared to different positions within large gaps. There are no significant differences; neither among the positions nor among small and large gaps. 
Die Spearman-Rang-Korrelation zwischen dem Anteil direkter Strahlung (DSF) und der Anzahl der nach dem Störungsereignis gekeimten Jungwuchsindividuen pro Hektar beträgt -0,19 $(p=0,37)$.

\section{Baumartenanteile}

Die Verjüngung setzte sich, sowohl in den kleinen als auch in den großen Befallsflächen, hauptsächlich aus Fichte, Vogelbeere und Bergahorn zusammen (Tabelle 5.2). Subalpin waren die mittleren Anteile der Fichtenverjüngung in den kleinen Befallsflächen zugunsten der Vogelbeere tendenziell geringer als in den großen Befallsflächen.

Tabelle 5.2 Mittlere Jungwuchsdichten $[\mathrm{n} / \mathrm{ha}] \pm$ zweifacher Standardfehler und Baumartenanteile der nach dem Störungsereignis gekeimten Individuen an den Positionen innerhalb der Störungsfläche. Sterne kennzeichnen signifikante Unterschiede der Jungwuchsdichten zwischen den Positionen in den Höhenstufen. Die Kategorie Gesamt beinhaltet zusätzlich zu den genannten Baumarten einzelne Individuen von Larix decidua, Abies alba, Fraxinus excelsior und Sorbus aria.

Table 5.2 Mean regeneration densities [n/ha] \pm twofold standard error and share of tree species of individuals that germinated after the disturbance event at different positions within the gaps. Stars indicate significant differences in regeneration densities among the different positions. Category Gesamt additionally includes rare individuals of Larix decidua, Abies alba, Fraxinus excelsior and Sorbus aria.

\begin{tabular}{|c|c|c|c|c|c|}
\hline & $\begin{array}{l}\text { Picea } \\
\text { abies }\end{array}$ & $\begin{array}{c}\text { Acer } \\
\text { pseudoplatanus }\end{array}$ & $\begin{array}{c}\text { Sorbus } \\
\text { aucuparia }\end{array}$ & $\begin{array}{c}\text { Fagus } \\
\text { sylvatica }\end{array}$ & Gesamt \\
\hline \multicolumn{6}{|c|}{ montan/hochmontan } \\
\hline \multirow[t]{2}{*}{ Klein } & $2.537 \pm 1.614$ & $1.397 \pm 1.452$ & $1.497 \pm 1.137$ & $16 \pm 31$ & $5.775 \pm 3.059$ \\
\hline & $44 \%$ & $24 \%$ & $26 \%$ & $0 \%$ & $100 \%$ \\
\hline \multirow[t]{2}{*}{ Nord } & $2.917 \pm 3.632$ & $417 \pm 833$ & $776 \pm 1.038$ & $0 \pm 0$ & $4.526 \pm 2.793$ \\
\hline & $64 \%$ & $9 \%$ & $17 \%$ & $0 \%$ & $100 \%$ \\
\hline \multirow[t]{2}{*}{ Ost } & $2.522 \pm 5.044$ & $3.445 \pm 4.244$ & $1.381 \pm 1.467$ & $417 \pm 833$ & $8.181 \pm 10.685$ \\
\hline & $31 \%$ & $42 \%$ & $17 \%$ & $5 \%$ & $100 \%$ \\
\hline \multirow[t]{2}{*}{ Süd } & $417 \pm 833$ & $0 \pm 0$ & $1.049 \pm 2.099$ & $0 \pm 0$ & $1.466 \pm 1.830$ \\
\hline & $28 \%$ & $0 \%$ & $72 \%$ & $0 \%$ & $100 \%$ \\
\hline \multirow[t]{2}{*}{ West } & $1.667 \pm 2.204$ & $480 \pm 959$ & $2.917 \pm 1.667$ & $1.250 \pm 2.500$ & $6.313 \pm 5.064$ \\
\hline & $26 \%$ & $8 \%$ & $46 \%$ & $20 \%$ & $100 \%$ \\
\hline \multirow[t]{2}{*}{ Mitte } & $3.691 \pm 2.633$ & $1.467 \pm 2.665$ & $5.127 \pm 7.962$ & $0 \pm 0$ & $10.713 \pm 14.052$ \\
\hline & $34 \%$ & $14 \%$ & $48 \%$ & $0 \%$ & $100 \%$ \\
\hline \multicolumn{6}{|l|}{ subalpin } \\
\hline \multirow[t]{2}{*}{ Klein } & $1.458 \pm 1.873 *$ & $563 \pm 1.125$ & $1.280 \pm 2.308$ & $0 \pm 0$ & $3.301 \pm 3.312$ \\
\hline & $44 \%$ & $17 \%$ & $39 \%$ & $0 \%$ & $100 \%$ \\
\hline \multirow[t]{2}{*}{ Nord } & $8.333 \pm 8.819$ & $480 \pm 959$ & $0 \pm 0$ & $0 \pm 0$ & $8.813 \pm 9.050$ \\
\hline & $95 \%$ & $5 \%$ & $0 \%$ & $0 \%$ & $100 \%$ \\
\hline \multirow[t]{2}{*}{ Ost } & $2.917 \pm 3.005$ & $63 \pm 126$ & $237 \pm 474$ & $0 \pm 0$ & $4.050 \pm 3.232$ \\
\hline & $72 \%$ & $2 \%$ & $6 \%$ & $0 \%$ & $100 \%$ \\
\hline \multirow[t]{2}{*}{ Süd } & $15.000 \pm 5.204 *$ & $63 \pm 126$ & $1.027 \pm 2.054$ & $0 \pm 0$ & $16.090 \pm 6.724$ \\
\hline & $93 \%$ & $0 \%$ & $6 \%$ & $0 \%$ & $100 \%$ \\
\hline \multirow[t]{2}{*}{ West } & $3.750 \pm 3.819$ & $0 \pm 0$ & $857 \pm 1.714$ & $0 \pm 0$ & $4.607 \pm 4.670$ \\
\hline & $81 \%$ & $0 \%$ & $19 \%$ & $0 \%$ & $100 \%$ \\
\hline \multirow[t]{2}{*}{ Mitte } & $3.750 \pm 6.292$ & $833 \pm 1.667$ & $833 \pm 1.667$ & $0 \pm 0$ & $5.417 \pm 5.833$ \\
\hline & $69 \%$ & $15 \%$ & $15 \%$ & $0 \%$ & $100 \%$ \\
\hline
\end{tabular}




\section{Höhenzuwachs}

Die Auswertung des Höhenzuwachses des Jungwuchses der Gemeinen Fichte zeigte für keine der drei Höhenklassen ein eindeutiges Muster in Bezug auf die einzelnen Positionen und Höhenstufen (Abb. 5.5). Meist zeigten jedoch die Probeflächen in den kleinen Befallsflächen und die Probeflächen in Mittelposition und am Südrand der Befallsflächen die signifikant höchsten Jahreszuwächse im Jahr 2011 auf.

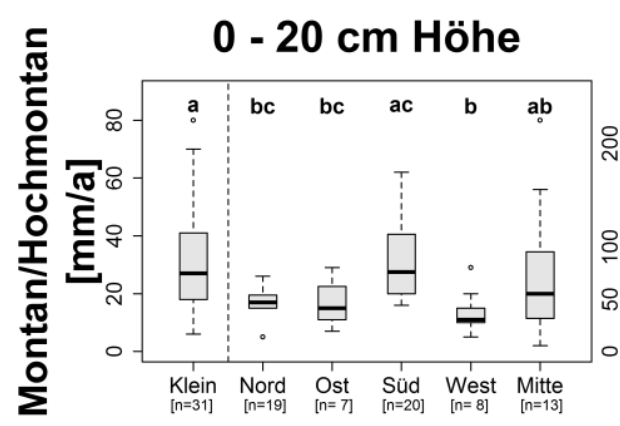

$20-50 \mathrm{~cm}$ Höhe
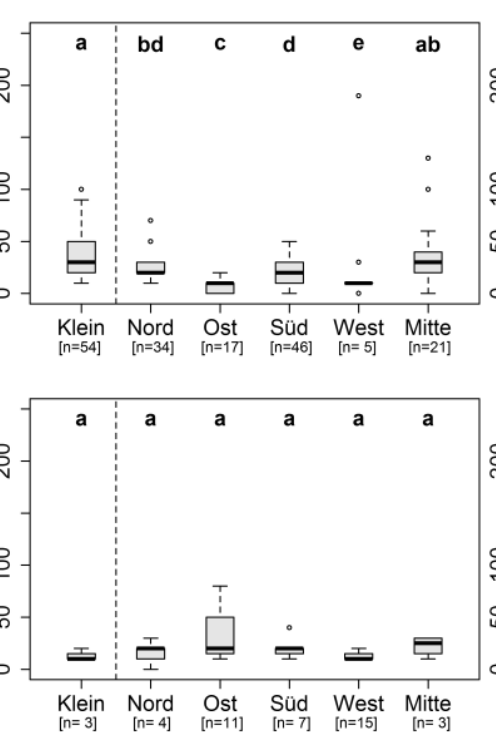

50 - 200 cm Höhe

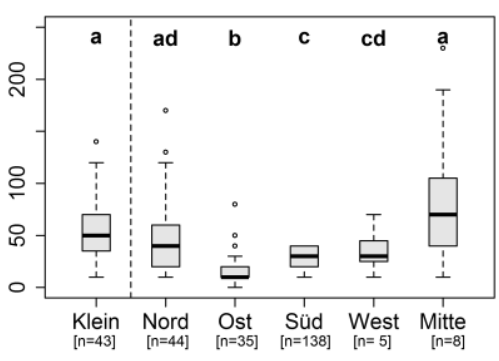

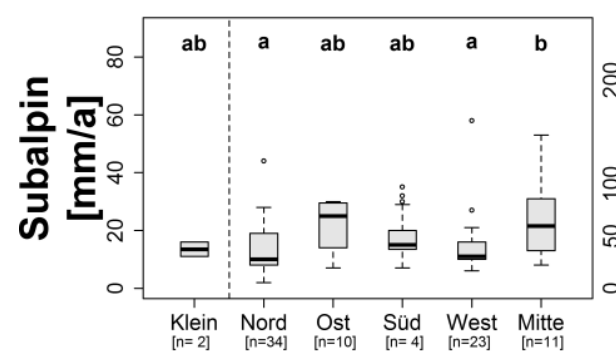

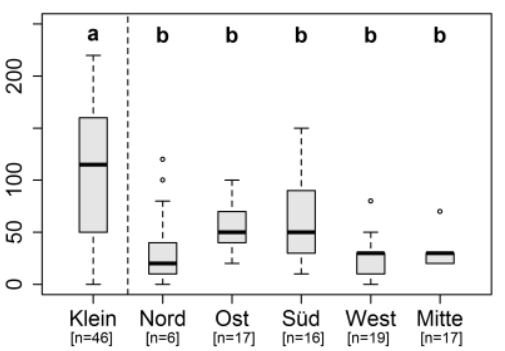

Abb. 5.5 Höhenzuwachs der Gemeinen Fichte im Jahr 2011 in den verschiedenen Positionen innerhalb kleiner und großer Befallsflächen. Unterschiedliche Kleinbuchstaben kennzeichnen signifikante Unterschiede zwischen den Positionen, [n=] beziffert die Anzahl der in die Auswertung integrierten unverbissenen Fichtenindividuen.

Fig. 5.5 Height increment of spruce in 2011 at different positions within small and large gaps. Different lowercase letters indicate significant differences among the positions. [n=] specifies the number of unbrowsed spruce individuals integrated in the analysis. 


\section{Einfluss von Flächenräumung und unterstützender Pflanzung auf Verjüngung und Artenvielfalt in der beginnenden Sukzession}

Die sechs im Rahmen dieser Studie untersuchten Borkenkäfer-Befallsflächen innerhalb des Maßnahmenbereichs Borkenkäferbekämpfung wurden im Jahr des Befalls vollständig geräumt. Es blieben keine entrindeten Stämme auf den Flächen zurück. Im darauffolgenden Frühjahr wurden durchschnittlich 2.500 Weißtannen (2/2 und 2/3; d.h. 2 Jahre im Saatbeet und 2 oder 3 Jahre im Verschulbeet, d.h. 4 bzw. 5-jährige Pflanzen) pro Hektar weitestgehend als Stockachselpflanzung auf den geräumten Flächen eingebracht. Auf den Flächen, auf denen keine Buchennaturverjüngung zu finden war, wurde die Pflanzzahl der Weißtanne pro Hektar reduziert und mit Europäischer Buche (1/0) auf 2.500 Bäume/ha vervollständigt.

\section{Standort}

Der Anteil an direkter Strahlung $1 \mathrm{~m}$ über Grund (DSF) war auf den geräumten Flächen im Mittel um $24 \%$ höher als auf den unbehandelten Flächen; signifikante Unterschiede waren aufgrund des geringen Stichprobenumfangs und der großen Varianz auf den geräumten Flächen jedoch nicht festzustellen (Abb. 5.6). Die Flächenausdehnung des Borkenkäferbefalls (Lückengröße) wies keinen signifikanten Unterschied zwischen den Mittelwerten ( \pm zweifacher Standardfehler) der unbehandelten $\left(5.386 \mathrm{~m}^{2} \pm 3.247\right)$ und geräumten $\left(2.580 \mathrm{~m}^{2} \pm 1.314\right)$ Flächen auf, war jedoch in der Tendenz auf den unbehandelten Flächen größer. Auch bei den Humusmächtigkeiten und dem Volumen des lebenden Bestandes waren keine signifikanten Unterschiede zwischen den beiden Behandlungsvarianten zu sehen, auch wenn in den ungeräumten Flächen tendenziell größere Mengen dünnerer unbefallener Fichten und damit ein höheres Bestandesvolumen vorzufinden waren. Durch die Räumung der Befallsflächen im Maßnahmenbereich Borkenkäferbekämpfung wurde jegliches befallene Fichtenstammholz entfernt. Dennoch befanden sich im Mittel immer noch $57 \mathrm{fm} / \mathrm{ha}$ in Form von Stubben auf den untersuchten Befallsflächen. Der Unterschied zu den unbehandelten Flächen war dennoch signifikant; dort waren im Mittel $546 \mathrm{fm} / \mathrm{ha}$ vorzufinden. Signifikant war auch der Unterschied des durchschnittlichen volumengewichteten Zersetzungsgrades des Totholzes zwischen den Flächen innerhalb $(2,5 \pm 0,2)$ und außerhalb des Maßnahmenbereichs Borkenkäferbekämpfung $(1,9 \pm 0,2)$. Luft- und Bodentemperatur (1 m über Grund) wurden nur auf jeweils zwei der sechs Probeflächen pro Behandlungsvariante erfasst. Tendenziell waren die geräumten Befallsflächen durch niedrigere Jahresmitteltemperaturen, aber von größeren täglichen Schwankungen zwischen Minimal- und Maximaltemperatur im Jahr 2013 geprägt (Abb. 5.6). Diese Unterschiede konnten statistisch aber nicht verifiziert werden. Prozentuale Deckung und mittlere Höhe der Bodenvegetation, als potentieller Konkurrenz des Jungwuchses, unterschieden sich nicht 
signifikant zwischen den beiden Behandlungsvarianten und lagen im Mittel bei $77 \% \pm 6 \%$ Bodendeckung, bzw. $19 \mathrm{~cm} \pm 2 \mathrm{~cm}$ Vegetationshöhe.

\section{Räumung und Pflanzung [Nein/Ja]}
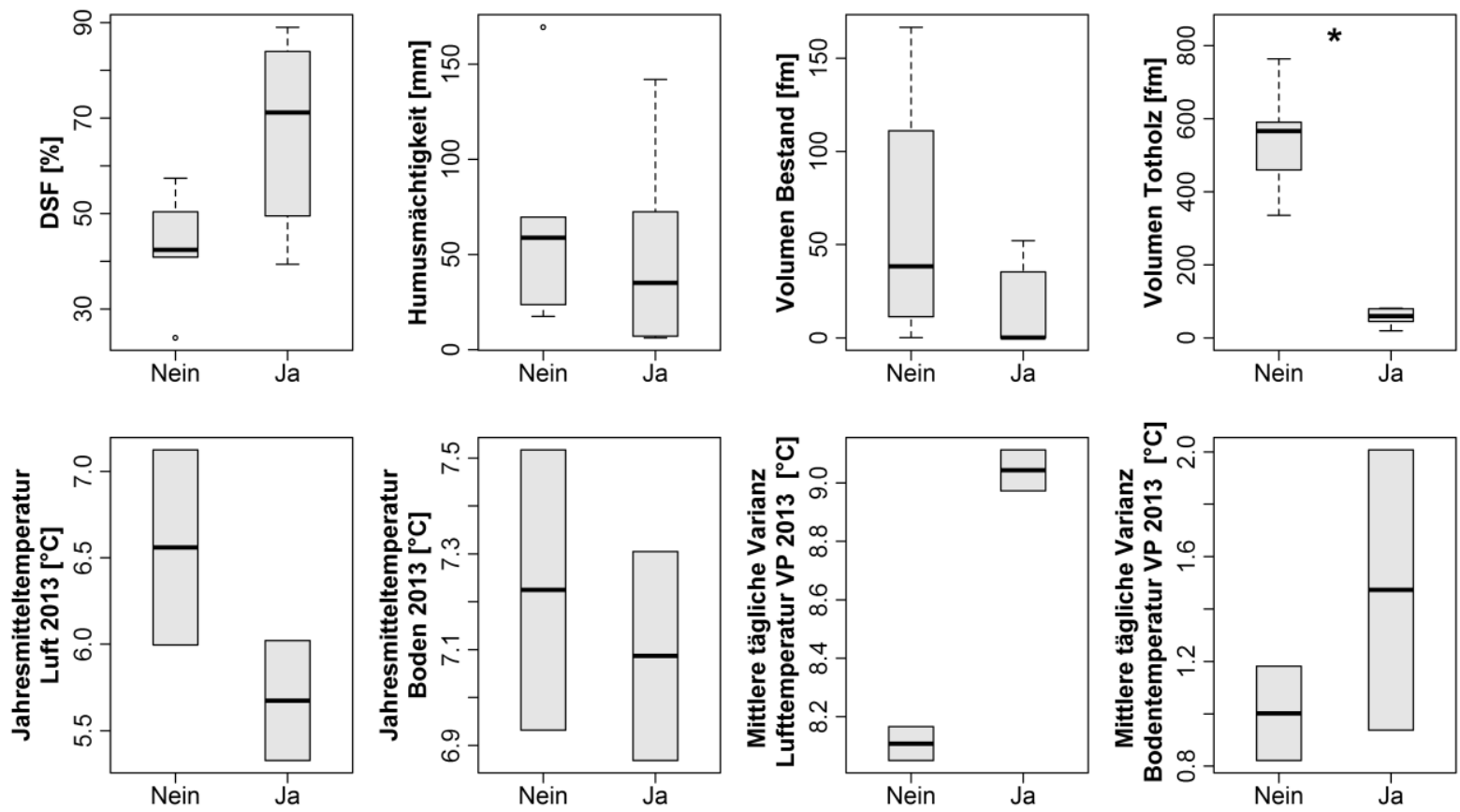

Abb. 5.6 Ausgewählte Standort- und Bestandescharakteristika von Befallsflächen ohne (Nein) und mit Räumung und Pflanzung (Ja). DSF: Anteil direkter Strahlung $1 \mathrm{~m}$ über Grund; VP: Vegetationsperiode (1. Mai bis 30. September). Sterne kennzeichnen signifikante Unterschiede zwischen den beiden Behandlungsmethoden.

Abb. 5.6 Selected site and stand characteristics of gaps outside (Nein) and inside the bark beetle management zone $(\mathrm{Ja})$. DSF: direct site factor, ratio of direct radiation $1 \mathrm{~m}$ above ground; VP: vegetation period (May - September). Stars indicate significant differences between the two management systems.

\section{Verjüngung}

\section{Jungwuchsdichte}

Es waren keine signifikanten Unterschiede in der Dichte des Jungwuchses zwischen den Flächen außerhalb und innerhalb des Maßnahmenbereichs Borkenkäferbekämpfung feststellbar, weder bei den erst nach dem Störungsereignis gekeimten Individuen, noch bei dem gesamten Jungwuchs (0-200 cm Höhe, Abb. 5.7). Beim kleinen Jungwuchs $(0-20 \mathrm{~cm})$ lagen die Verjüngungsdichten außerhalb der Managementzone signifikant über jenen innerhalb der Managementzone (Tabelle 5.2). Der Anteil an Jungwuchsindividuen mit Terminaltriebverbiss war auf den geräumten Flächen vergleichbar mit jenen außerhalb des Maßnahmenbereichs Borkenkäferbekämpfung und lag im Mittel von allen Probeflächen bei $47 \%$ ( $\pm 10 \%$ zweifacher Standardfehler). 
Räumung und Pflanzung [Nein/Ja]
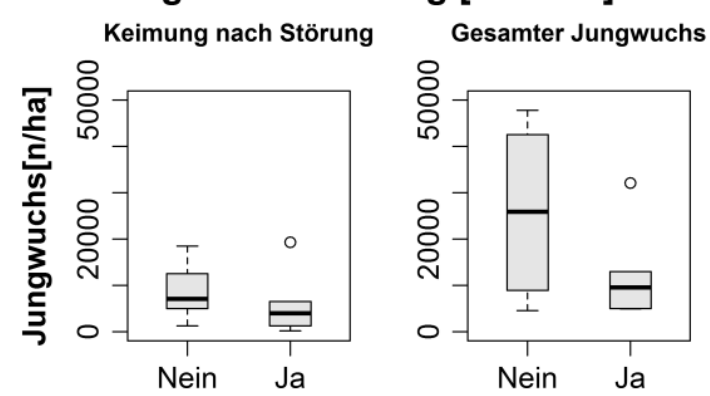

Abb. 5.7 Vergleich der Verjüngungsdichten zwischen Befallsflächen ohne (Nein) und mit Räumung und Pflanzung $(\mathrm{J} a$ ). Es bestehen keine signifikanten Unterschiede zwischen den beiden Behandlungsmethoden.

Fig. 5.7 Regeneration densities differentiated for those individuals that germinated after the disturbance event (left graph) and for all individuals (0 - $200 \mathrm{~cm}$ height, right graph) in gaps outside (Nein) and inside the bark beetle management zone $(J a)$. There are no significant differences between the two management systems.

\section{Baumartenanteile}

Beim Vergleich der Baumartenanteile der beiden Behandlungsmaßnahmen zeigten sich besonders beim mittleren Jungwuchs $(20-50 \mathrm{~cm})$ vergleichsweise hohe Anteile von Buche und Tanne in der Managementzone (Tabelle 5.2). Bei der Tanne waren diese Unterschiede in den Anteilen auch signifikant (Abb. 5.8).

Tabelle 5.3 Mittlere Jungwuchsdichten [n/ha] \pm zweifacher Standardfehler der einzelnen Baumarten und Jungwuchs-Höhenklassen auf Befallsflächen ohne (Nein) und mit Räumung und Pflanzung (Ja). Andere beinhaltet einzelne Individuen von Sorbus aria, Ulmus glabra und Salix sp.

Table 5.3 Mean regeneration densities $[\mathrm{n} / \mathrm{ha}] \pm$ twofold standard error of tree species within three height classes in gaps outside (Nein) and inside the bark beetle management zone $(J a)$. Andere includes single individuals of Sorbus aria, Ulmus glabra und Salix sp.

\begin{tabular}{|c|c|c|c|c|c|c|c|c|}
\hline & $\begin{array}{l}\text { Picea } \\
\text { abies }\end{array}$ & $\begin{array}{c}\text { Larix } \\
\text { decidua }\end{array}$ & $\begin{array}{c}\text { Abies } \\
\text { alba }\end{array}$ & $\begin{array}{c}\text { Acer } \\
\text { pseudopl. }\end{array}$ & $\begin{array}{l}\text { Sorbus } \\
\text { auc. }\end{array}$ & $\begin{array}{c}\text { Fagus } \\
\text { sylvatica }\end{array}$ & Andere & Gesamt \\
\hline \multicolumn{9}{|c|}{ kleiner Jungwuchs $(0-20 \mathrm{~cm})$} \\
\hline Nein & $5.625 \pm 3.010$ & $0 \pm 0$ & $0 \pm 0$ & $5.625 \pm 4.598$ & $4.375 \pm 5.618$ & $208 \pm 417$ & $1.042 \pm 1.635$ & $16.875 \pm 5.625$ \\
\hline Ja & $3.542 \pm 3.841$ & $0 \pm 0$ & $0 \pm 0$ & $1.875 \pm 2.016$ & $208 \pm 417$ & $0 \pm 0$ & $0 \pm 0$ & $5.625 \pm 5.429$ \\
\hline \multicolumn{9}{|c|}{ mittelgroßer Jungwuchs $(20-50 \mathrm{~cm})$} \\
\hline Nein & $1.667 \pm 2.608$ & $0 \pm 0$ & $63 \pm 80$ & $2.642 \pm 3.326$ & $1.384 \pm 1.893$ & $63 \pm 126$ & $157 \pm 180$ & $5.975 \pm 6.238$ \\
\hline Ja & $409 \pm 383$ & $31 \pm 63$ & $409 \pm 205$ & $346 \pm 343$ & $189 \pm 138$ & $943 \pm 1.452$ & $126 \pm 252$ & $2.453 \pm 1.329$ \\
\hline \multicolumn{9}{|c|}{ großer Jungwuchs $(50-200 \mathrm{~cm})$} \\
\hline Nein & $533 \pm 829$ & $11 \pm 22$ & $11 \pm 22$ & $511 \pm 434$ & $222 \pm 270$ & $144 \pm 213$ & $178 \pm 330$ & $1.611 \pm 1.384$ \\
\hline Ja & $78 \pm 87$ & $0 \pm 0$ & $89 \pm 107$ & $1.489 \pm 1.572$ & $1267 \pm 1386$ & $467 \pm 467$ & $256 \pm 335$ & $3.644 \pm 3.397$ \\
\hline
\end{tabular}


Räumung und Pflanzung [Nein/Ja]
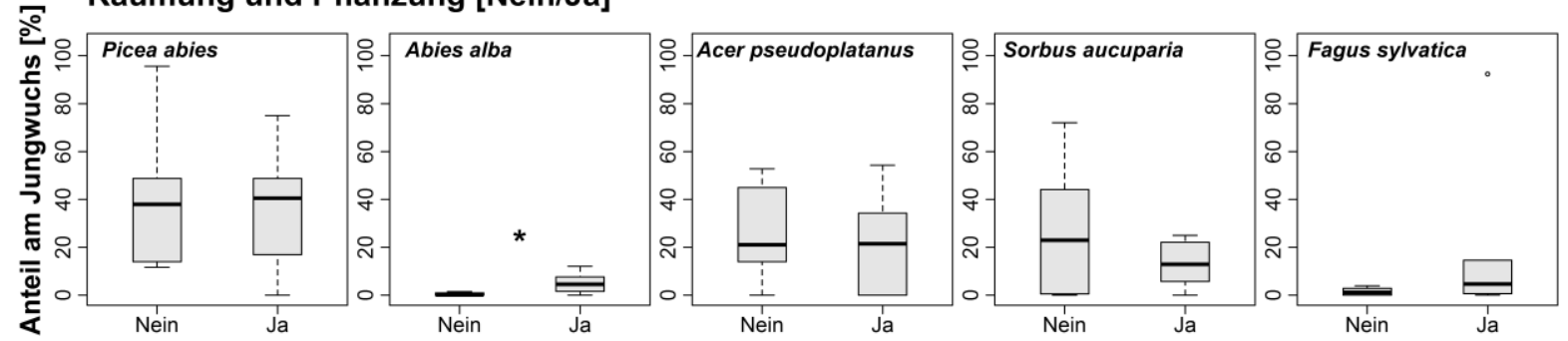

Abb. 5.8 Anteile der Hauptbaumarten auf den Probeflächen ohne (Nein) und mit Räumung und Pflanzung $(J a)$. Sterne kennzeichnen signifikante Unterschiede zwischen den beiden Behandlungsmethoden.

Fig. 5.8 Share of main tree species on plots outside (Nein) and inside the bark beetle management zone (Ja). Stars indicate significant differences between the two management systems.

\section{Artenvielfalt}

Die Untersuchung der Artenvielfalt basiert für die faunistischen Artengruppen und die totholzbesiedelnden Pilze nur auf drei der sechs Probeflächen pro Behandlungsmaßnahme und nur für die Gefäßpflanzen auf jeweils sechs Probeflächen. Die Aussagekraft der Ergebnisse ist daher eingeschränkt, auch wenn signifikante Unterschiede ersichtlich sind. Während Schnecken, Wanzen und bestäubende Käferarten mit signifikant höheren Artenzahlen auf den geräumten Flächen zu finden waren, wiesen totholzbesiedelnde Käferarten signifikant höhere Artenzahlen in den vom Management unbeeinflussten Beständen auf (Abb. 5.9). Für die meisten untersuchten faunistischen Artengruppen, für Gefäßpflanzen und totholzbesiedelnde Pilze waren keine signifikanten Unterschiede zwischen den beiden Managementformen festzustellen. Auch bei der Anzahl der in den Roten Liste Bayerns geführten gefährdeten Pflanzen-, Pilz- und Käferarten zeigten sich keine signifikanten Unterschiede zwischen den geräumten und ungeräumten Befallsflächen.

Auch bei gleichen Artenzahlen kann sich die Artenzusammensetzung auf den Probeflächen der beiden Managementformen unterscheiden. Den höchsten Arten-Turnover zwischen den beiden Managementformen wiesen hier die xylobionten Artengruppen der Käfer und Pilze, die epigäischen Käfer und Spinnentiere und die Bestäubergruppen der Käfer und Stechimmen auf (Abb. 5.10). 


\section{Räumung und Pflanzung [Nein/Ja]}

\section{Autotroph Xylobiont}

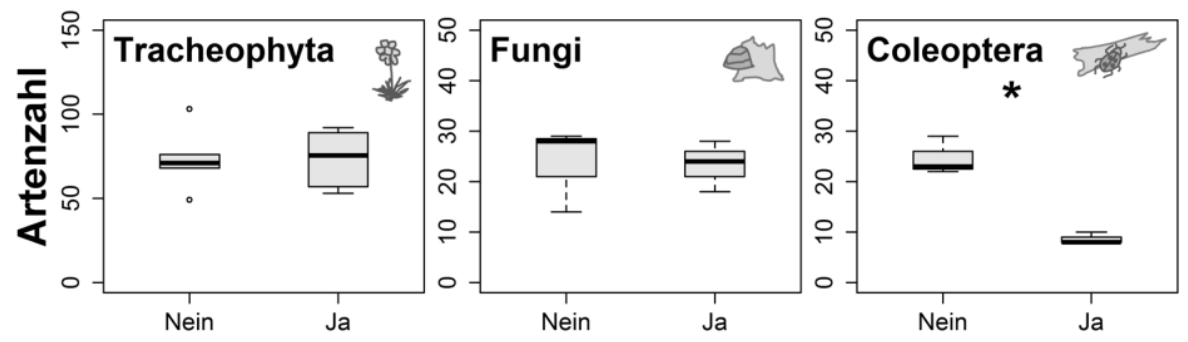

Epigäisch
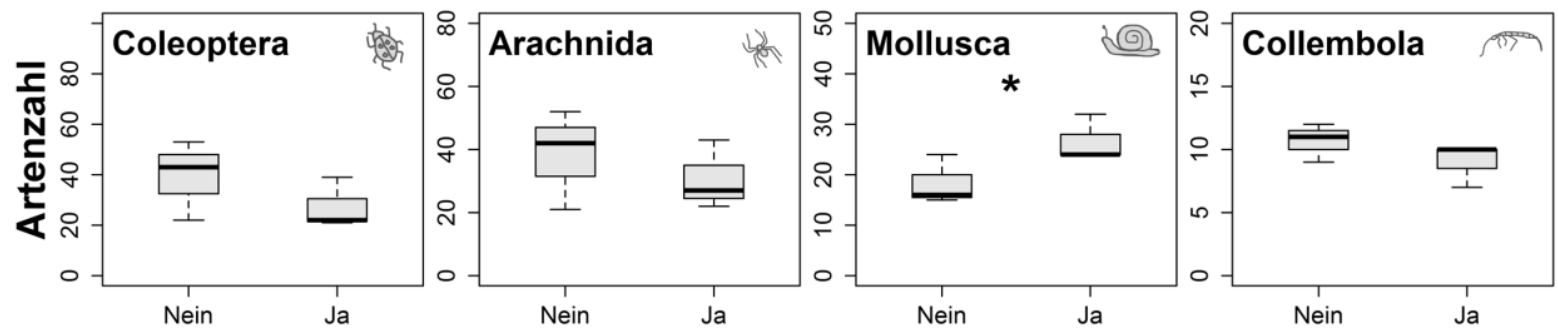

Phytophag

Bestäuber

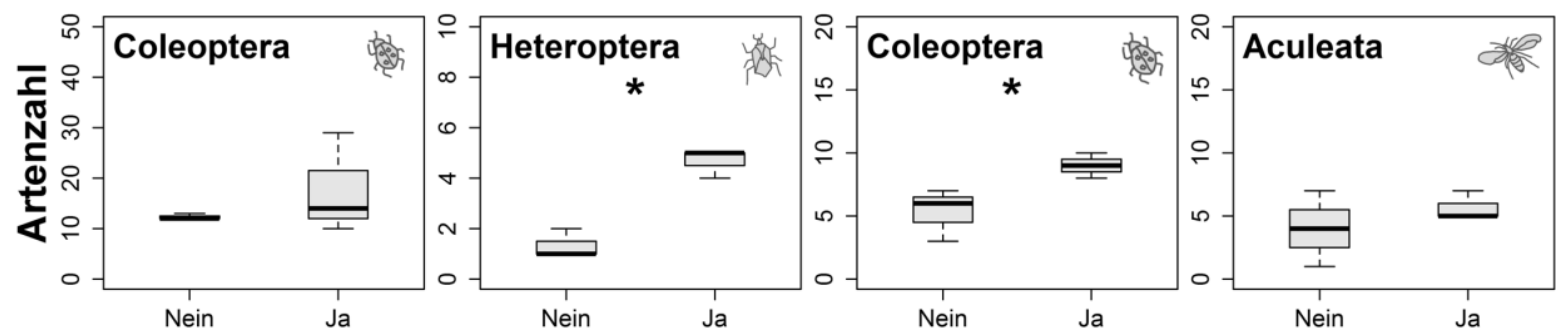

Abb. 5.9 Artenzahlen ausgewählter Artengruppen ausgewertet nach funktionellen Gruppen auf den Probeflächen ohne (Nein) und mit Räumung und Pflanzung (Ja). Sterne kennzeichnen signifikante Unterschiede zwischen den beiden Behandlungsmethoden. Tracheophyta: Gefäßpflanzen, Fungi: Pilze, Coleoptera: Käfer, Arachnida: Spinnentiere, Mollusca: Schnecken, Collembola: Springschwänze, Heteroptera: Wanzen, Aculeata: Stechimmen.

Fig. 5.9 Species densities of selected species groups analyzed as functional groups on plots outside (Nein) and inside the bark beetle management zone $(J a)$. Stars indicate significant differences between the two management systems. Tracheophyta: vascular plants, Coleoptera: beetles, Arachnida: spiders, Mollusca: snails, Collembola: springtails, Heteroptera: true bugs, Aculeata: aculeates. 


\section{Räumung und Pflanzung [Nein/Ja] \\ Autotroph Xylobiont}

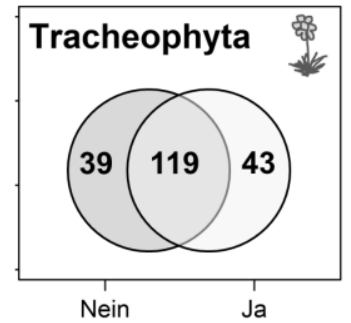

Epigäisch

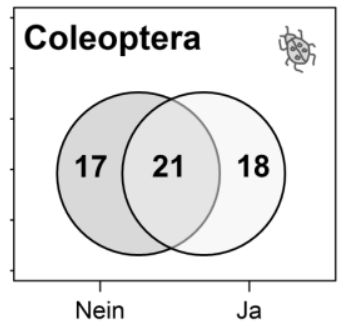

Phytophag

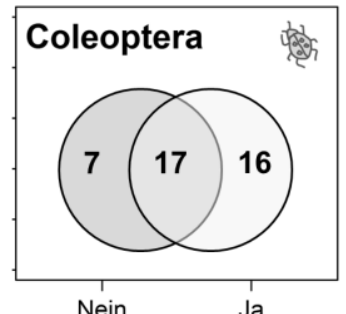

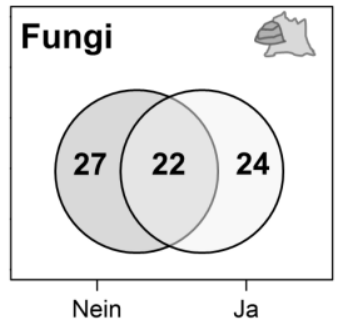
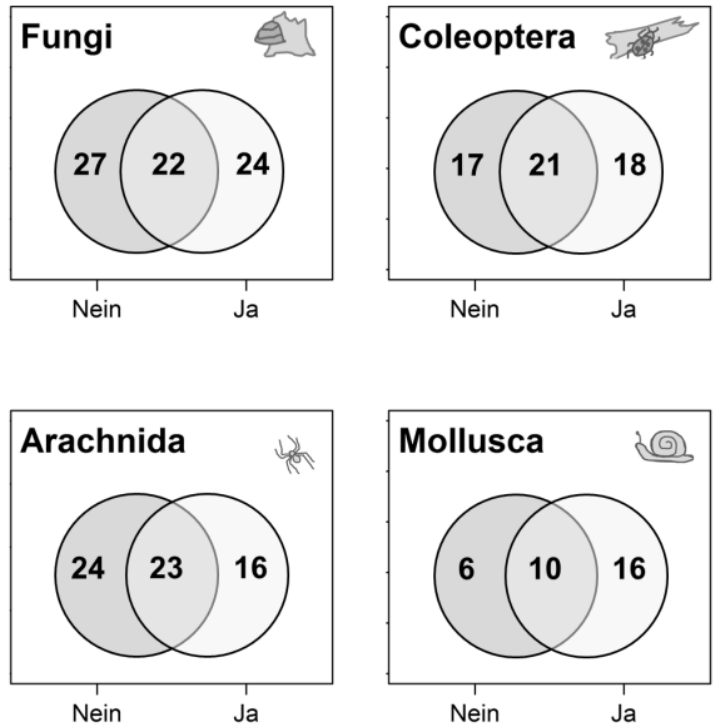

Bestäuber

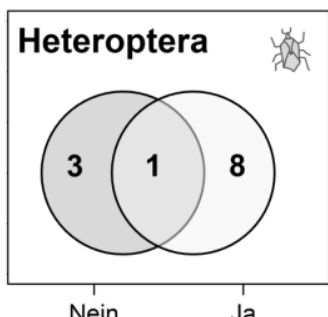

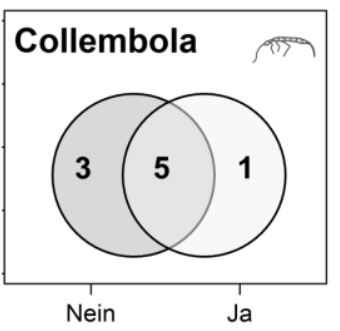

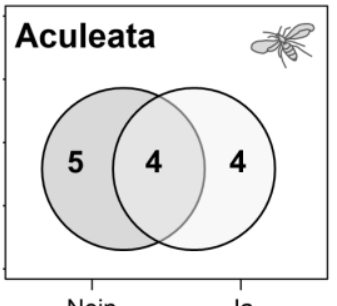

Abb. 5.10 Venn-Diagramm der untersuchten funktionellen Gruppen mit Anzahl der Arten die nur auf den Probeflächen ohne Räumung und Pflanzung (Nein, linker Kreis), jenen Arten die nur auf den Probeflächen mit Räumung und Pflanzung vorkamen ( $J a$, rechter Kreise) und jenen Arten die bei beiden Manaagmenetvarianten gefunden wurden (überlappender Kreisbereich).

Abb. 5.10 Venns diagramm of studied functional groups with number of species occurring solely on plots outside the bark beetle management zone (Nein, left circle), number of species occurring solely on plots inside the bark beetle management zone ( $\mathrm{J}$, right circle) and the number of species occurring on plots of both management systems (overlap of circles).

Die Daten der untersuchten Artengruppen dieser Teilstudie innerhalb und außerhalb des Maßnahmenbereichs Borkenkäferbekämpfung sind ebenfalls in eine globale Meta-Analyse zum Einfluss der Flächenräumung auf die Biodiversität eingeflossen (Thorn et al. submitted). 


\section{Kapitel 6}

\section{Diskussion}
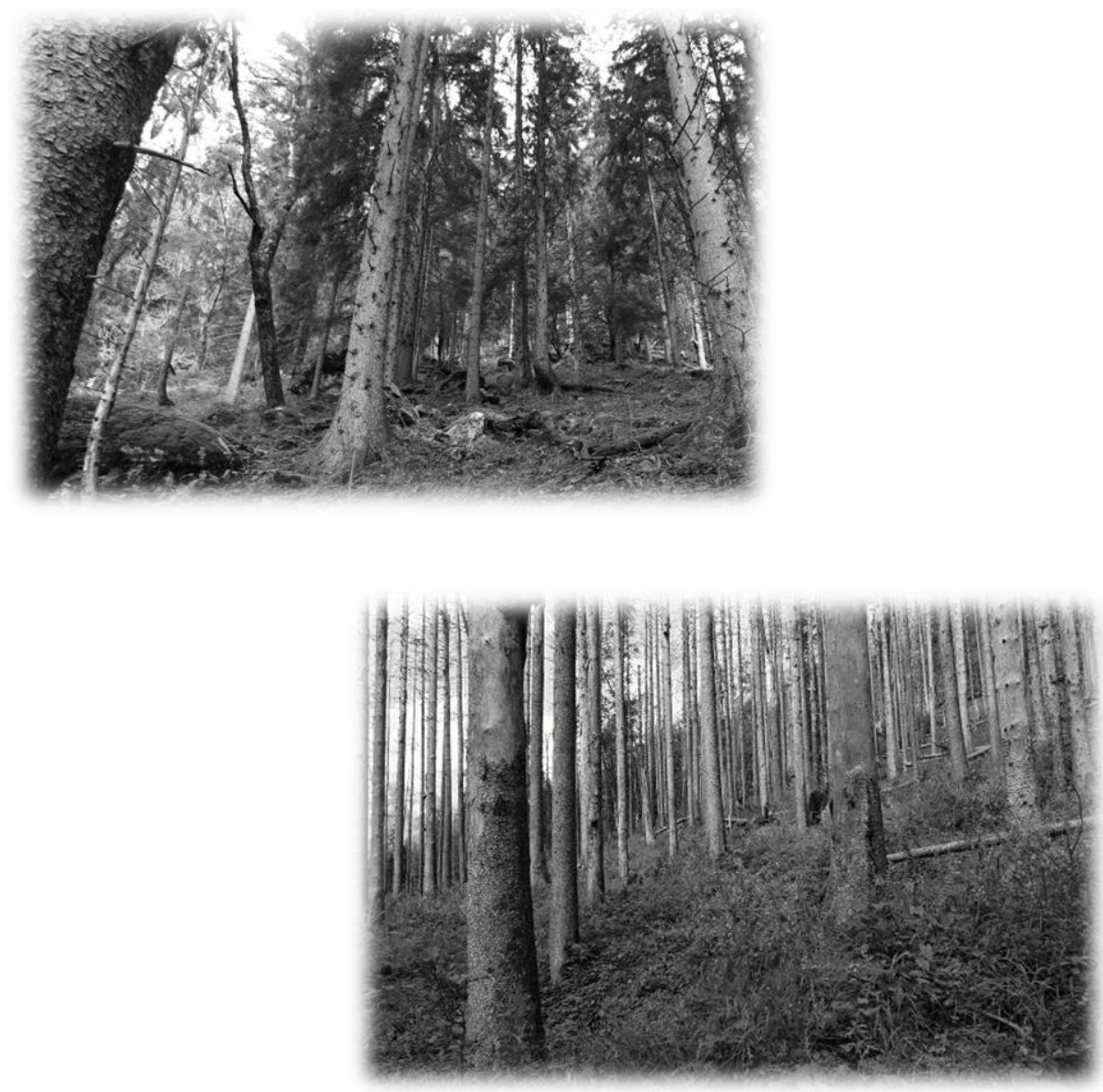

Unechte Zeitreihe mit Fichtenaltbestand, beginnendem und fortgeschrittenem

frühsukzessionalem Stadium in montaner sonnseitiger Lage in Fischunkel am Obersee (Fotos: M.B. Winter).

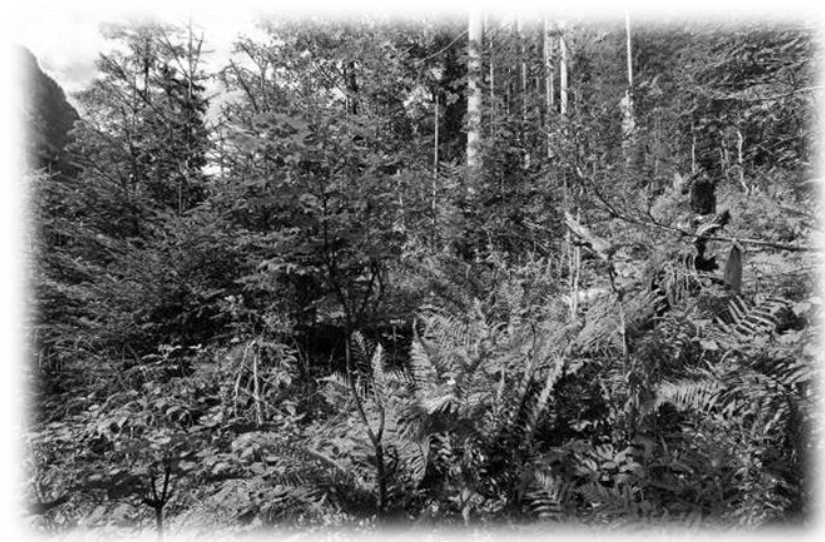




\section{Räumliche Verbreitung des Borkenkäferbefalls}

Das natürliche Störungsregime des Untersuchungsgebiets besteht neben lokalen Störungen durch Lawinenabgänge hauptsächlich aus einer Kombination aus Windwürfen und Borkenkäferbefall mittelgroßer Flächendimensionen (Konnert und Siegrist 2000). Die im Nationalpark Berchtesgaden durch Borkenkäferbefall verursachten Lücken waren mit ihrer mittleren Flächenausdehnung von 0,07 ha (Luftbild 1997) und 0,29 ha (Luftbild 2012) und einer Gesamt-Befallsfläche von etwa 30 ha (1997) und 260 ha (2012) außerhalb des Maßnahmenbereichs Borkenkäferbekämpfung deutlich kleiner und zerstreuter als in anderen unbewirtschafteten Waldgebieten Zentraleuropas (siehe Abb. 2.1. und 2.3, Meyer und Petersen 2003, Lausch et al. 2011) und Nordamerikas (Meddens et al. 2012, Meddens und Hicke 2014). In den Jahren zwischen 1990 und 2007 führte der Borkenkäferbefall allein im Nationalpark Bayerischer Wald zum großflächigen Absterben der Fichten auf 5.370 ha Waldfläche in den Hochlagen (Lausch et al. 2011). Nach großflächigen Sturmereignissen 1868 und 1870 und flächigen Wiederaufforstungen mit teils nicht autochtonem Pflanzgut, waren die Hochlagenbestände des Bayerischen Waldes zum Zeitpunkt des Borkenkäferbefalls sehr homogen in Bezug auf Altersverteilung und Bestandesstrukturen (Bauer 2002). Weitere Hintergründe für die Unterschiede in der Flächenausbreitung und Befallsdynamik sind jedoch noch weitgehend ungeklärt. Auch im Nationalpark Berchtesgaden konnten eine Ausweitung der Schwärmaktivität des Buchdruckers in frühere Perioden des Jahres und höhere Lagen des Gebiets (Kautz et al. 2011) und eine erhebliche Prädisposition der Fichte unter Trockenstress in den letzten Jahrzehnten nachgewiesen werden (Hartl-Meier et al. 2014). Mögliche Faktoren für die bislang kleinflächigere Ausbreitung im Nationalpark Berchtesgaden sind die Limitierung der Borkenkäfergradationen durch weniger Borkenkäfergenerationen pro Jahr aufgrund kälterer Klimabedingungen zumindest in den Hochlagen (Nierhaus-Wunderwald und Forster 2004) und die große topographische Heterogenität des Gebiets, verbunden mit größerer Heterogenität der Standort- und damit auch Bestandesbedingungen (Konnert und Siegrist 2000, Konnert 2004).

Eine Prognose für die künftige Stabilität der noch bestehenden Fichtenaltbestände gegenüber Borkenkäferbefall kann durch diese Luftbild-Auswertungen nicht gegeben werden. Aufgrund der geringen mittleren Befallsflächengrößen sind die standörtlichen Veränderungen (z.B. von Mikroklima, Humusabbau und Samenverfügbarkeit) durch den Befall moderat (siehe Tabelle 2.1) und ermöglichen eine zeitnahe Verjüngung der Flächen. Der auf den kleinräumig und zerstreut liegenden Störungsflächen heterogen aufwachsende Jungwuchs, mit zumindest lokal reduzierten Fichtenanteilen (siehe Tabelle 2.3), macht eine zukünftig erhöhte Bestandesstabilität gegenüber Störungen wahrscheinlich (Turner et al. 2013). 


\section{Veränderung der Standort- und Bestandesverhältnisse}

Die in dieser Studie genutzte Methodik der unechten Zeitreihe deckt, neben der Sukzession vom Fichtenaltbestand zum fortgeschrittenen frühsukzessionalen Stadium, mehrere zeitgleich stattfindende Entwicklungen bzw. Gradienten ab: zum einen einen Managementgradienten mit abnehmendem Einfluss der historischen Waldbewirtschaftung mit fortschreitender Zeit seit Einrichtung des Nationalparks 1978, und damit einhergehend eine Entwicklung von den sekundären, meist reinen Fichtenbeständen in Richtung heutiger potentieller natürlicher Vegetation, zum anderen mehrere lokale Management-Entscheidungen, aber auch global verursachte zeitliche Entwicklungen, wie die Zunahme der Jagdintensität im Gebiet, der Erhöhung von Stickstoffeinträgen über die Luft und die Wirkung klimatischer Veränderungen. Diese Einflussfaktoren lassen sich nicht vollständig vom Zielgradienten, d.h. der seit der Störung vergangenen Zeit, dieser Untersuchung trennen. Wo diese Faktoren in den Ergebnissen aufscheinen, wie z.B. die zunehmende Jagdintensität, werden sie im Folgenden diskutiert. Bei den überregional wirkenden Faktoren wird erwartet, dass sie in vergleichbaren Gebieten ähnlichen Einfluss ausüben und damit die Übertragbarkeit dieser Studie nicht grundsätzlich einschränken.

Das Absterben der Fichtenaltbestände durch den Borkenkäferbefall führte im Untersuchungsgebiet zu einer signifikanten Reduktion der Bestandesvolumina und der Kronenüberschirmung auf den Befallsflächen, bei gleichzeitig massiver Zunahme an stehendem Totholz (siehe Tabellen 2.1, 3.2 und 4.2). Erhebliche Anteile des stehenden Totholzes brachen bei fortschreitender Zersetzung im Verlauf der untersuchten etwa 20-jährigen Sukzession zusammen und veränderten damit ihre Wirkung als stabilisierende Objekte gegenüber Schneebewegungen und Steinschlag auf der Fläche (Kupferschmid Albisetti et al. 2003, Bebi et al. 2015), als Keimsubstrat für die Naturverjüngung (Abb. 4.2, Szewczyk und Szwagrzyk 1996, Zielonka 2006) und als Habitat für totholzbesiedelnde Artengemeinschaften (Saint-Germain et al. 2007, Bässler et al. 2012).

Die durch das Absterben des Kronendachs erhöhte Strahlung am Waldboden charakterisierte sowohl das Stadium der beginnenden als auch der fortschreitenden Sukzession (siehe Tabellen 2.1, 3.2 und 4.2). Die auf den Befallsflächen der beginnenden Sukzession mit mehr als einem Hektar Flächenausdehnung geschätzten Strahlungswerte unterschieden sich durch vereinzelte Laubbäume, Lärchen und überlebende Fichten weder von den Befallsflächen mit Flächenausdehnungen kleiner einem Hektar, noch zwischen einzelnen Positionen innerhalb der großen Befallsflächen (Abb. 5.2). Mit den durch die Störung erhöhten Strahlungswerten ging im Verlauf der Sukzession eine zunehmende Dominanz der Bodenvegetation in Bezug auf Bodendeckung und Vegetationshöhe einher (Tabelle 3.2). Die ausbleibende Streunachlieferung aufgrund der fehlenden Baumschicht und die zunehmende Deckung der Bodenvegetation reduzierten gleichzeitig den Anteil der 
Streubedeckung auf dem Waldboden (Abb 4.2). In der Literatur werden verschiedene bodenphysikalische Prozesse diskutiert, die mit dem Absterben des Kronendachs durch natürliche Störungen in Verbindung stehen: Veränderungen des Streueintrags, der Erosion, der Bioturbation, bodenchemischer Prozesse und der Auswaschung von organischem Material und von Nährelementen (Lüscher 2002, Spielvogel et al. 2007). Während in anderen Gebieten teilweise keine Veränderungen oder auch kurzfristige Anreicherungen an organischem Material im Oberboden durch großflächige Störungen beobachtet werden konnten (zusammengefasst in Spielvogel et al. 2007), weisen die Studien in kalkalpinen Bergwäldern einheitlich einen verstärkten Humusabbau im Nachgang von Störungsereignissen nach (Kohlpaintner und Göttlein 2009, Hollaus 2012). Selbst moderate Ernteverfahren (Femel- bis Schirmschlag) können auf den flachgründigen Kalkböden durch Nährstoffentzug und aktive Humusverwundung zu erheblichem Humusabbau in den Bergwäldern führen (Christophel et al. 2013). Durch den hohen Anteil der Tangelhumusböden (O/C-Böden) im Gebiet, bei denen durch nicht ausgebildete Mineralbodenhorizonte sämtliche Bodenfunktionen (z.B. Wurzelraum, Wasserspeicherung, Nährstoffversorgung) am Tangelhumuskörper hängen (Bochter 1984), wird ein Humusabbau als wesentlicher Einflussfaktor für die weitere Waldentwicklung angesehen (Baier 2006, Kohlpaintner und Göttlein 2009). Entgegen den bisherigen Erkenntnissen waren in dieser Untersuchung jedoch keine Zeichen des Humusabbaus durch das Störungsereignis und die nachfolgende Sukzession in den Bestandeslücken nachweisbar (siehe Tabelle 2.1). Dies mag zum einen an den bereits drastisch reduzierten Humusvorräten durch die jahrhundertelange intensive Holznutzung nach Aufkommen der Salinenindustrie im Berchtesgadener Land liegen (Prietzel und Christophel 2014) und zum anderen an den verhältnismäßig kleinen Lücken und dem zügigen Bewuchs der Störungsflächen durch die Bodenvegetation. Gleichzeitig stößt die in der vorliegenden Studie genutzte Methodik der unechten Zeitreihe bei dieser Fragstellung und der hohen kleinstandörtlichen Heterogenität im Gebiet an ihre Grenzen.

Nach bisherigen Studien über den Zusammenhang zwischen Bestandeslückengröße und Mesoklima waren durch den Borkenkäferbefall folgende Veränderungen in den Bestandeslücken zu erwarten: höhere mittlere Jahrestemperaturen und damit einhergehend eine Verlängerung der Vegetationsperiode, größere tägliche Schwankungen der Lufttemperatur (durch verstärkte Einstrahlung und Erwärmung am Tag, aber auch erhöhter Auskühlung durch Abstrahlung bei Nacht) und eine zeitliche Verlängerung der Schneebedeckung (aufgrund vermehrter Schneeablagerung durch Windverwirbelung in den Lücken und verzögerter Schneeschmelze durch fehlende Bäume, an deren dunkler Rinde im Frühjahr ein indirekter Strahlungs- und Schmelzeffekt zu erwarten wäre; z.B. Gray et al. 2002, Margreth 2004, Ritter et al. 2005, Zhongsheng et al. 2012). Die Ergebnisse der vorliegenden Untersuchung wiesen in der Tendenz auf entsprechende Verhältnisse hin, d.h. tendenziell längere Vegetationsperioden, größere tägliche Schwankungen der Lufttemperatur und 
längere Schneebedeckung in den Lücken; signifikante Unterschiede zwischen Fichtenaltbeständen und Störungsflächen waren jedoch für keinen der Parameter nachweisbar (Tabelle 2.1). Die in der Literatur genannten Lückengrößen lagen z.T. unter den im Untersuchungsgebiet vorgefundenen Lückengrößen und scheinen damit keine stichhaltige Erklärung für die fehlenden Unterschiede zu liefern. Eine mögliche Erklärung der nicht vorhandenen Signifikanz in dieser Studie sind Limitierungen der angewandten Methodik, wie der kurze Messzeitraum über zwei Jahre, die im Verhältnis zur Anzahl abgedeckter Standort- und Bestandesbedingungen (montan bis subalpin, sonnseitig und schattseitig, Fichtenaltbestand bis fortschreitende Sukzession) geringe Anzahl von 34 Temperaturloggern und die große mikrotopographische Heterogenität des Gebiets, bei dem eine unterschiedliche Positionierung des Temperaturloggers innerhalb einer Probefläche bereits zu erheblichen Unterschieden in der Messreihe führen kann. Dennoch kann angenommen werden, dass das nach Absterben des Fichtenaltbestandes verbleibende stehende Totholz und die zügig aufkommende Naturverjüngung, die von Kahlschlägen bekannten extremeren Lückenbedingungen teilweise abpuffern konnten.

Bei großflächigem vollständigem Absterben der Fichtenaltbestände durch den Borkenkäferbefall wäre von einer starken Limitierung der Samenverfügbarkeit der Fichte für zukünftige Naturverjüngungsprozesse auszugehen. In der Literatur wird häufig eine mittlere Verbreitungsdistanz der Fichtensamen von 30-50 m erwähnt (z.B. Kohlermann 1950, Kutter und Gratzer 2006, Cremer et al. 2012). Bei den Befallsflächen < 1 ha lag der nächste Fichtensamenbaum gemittelt über alle drei Höhenstufen zu 95 \% innerhalb einer Distanz von 50 m (Tabelle 2.2). Bei den Befallsflächen > 1 ha lag der Anteil an Probeflächen mit mindestens einem Fichtensamenbaum innerhalb einer Distanz von $50 \mathrm{~m}$ bei $87 \%$. Auf einzelnen Probeflächen, hauptsächlich auf den Mittelpositionen der großen Störungsflächen, waren die nächsten Fichtensamenbäume weiter als $50 \mathrm{~m}$ entfernt (Tabelle 5.1). Damit ist, zumindest temporär, mit einer reduzierten Samenzufuhr der Fichte durch die umliegenden Altbestände zu rechnen. Durch Sekundärtransport der Fichtensamen, etwa durch Verwehung auf festen Schneedecken, kann es allerdings zusätzlich zum Sameneintrag von weiter entfernt stehenden Altbeständen kommen. Dieser bewegt sich jedoch meist auf vernachlässigbar geringem Niveau (Greene und Johnson 1997).

Neben der Gemeinen Fichte befanden sich regelmäßig Samenbäume von Bergahorn und Vogelbeere auf, bzw. in der Nähe der Probeflächen; in den tieferen Lagen begleitet von der Gemeinen Esche, mit zunehmender Höhenlage auch vermehrt von der Europäischen Lärche. Weißtanne und Europäische Buche waren hingegen aufgrund der jahrhundertelangen Nutzungsgeschichte deutlich seltener zu finden als dies in den natürlichen Waldgesellschaften der Bergmischwälder zu erwarten wäre (Tabelle 2.1, Knott et al. 1988, Walentowski et al. 2006). 


\section{Verjüngungsdynamik}

Zwei Jahrzehnte nach dem Störungsereignis waren die durch den Borkenkäferbefall verursachten Bestandeslücken in montaner Lage mit einem Median von etwa 5.000 Pflanzen $>50 \mathrm{~cm}$ und weiteren etwa 5.000 Pflanzen $<50 \mathrm{~cm}$ pro Hektar bereits überwiegend dicht bestockt, während in hochmontaner Lage mit einem Median von etwa 1.000 Pflanzen $>50 \mathrm{~cm}$ und weiteren etwa 3.000 Pflanzen $<50 \mathrm{~cm}$ pro Hektar noch größere unbestockte Bereiche vorzufinden waren (siehe Abb. 2.5). Beide Jungwuchsdichten liegen im Bereich der Ergebnisse bisheriger mitteleuropäischer Untersuchungen nach Windwurf oder Borkenkäferbefall (Bauer 2002, Wohlgemuth et al. 2002, Meyer und Petersen 2003, Keidel et al. 2008, Jonášová und Prach 2004, Zeppenfeld et al. 2015). Die Ergebnisse bestätigen die Erwartung, dass die durch den Borkenkäferbefall verursachten Standortveränderungen den natürlichen Verjüngungsprozess nicht unterbinden werden. Die von Diaci und Ko-Autoren (2005) in subalpinen Fichtenbeständen beobachteten Unterschiede im Verjüngungserfolg je nach Position innerhalb einer Bestandeslücke, konnten in den großen Befallsflächen (Abb. 5.4 und 5.5) nicht bestätigt werden, was vermutlich auf einzelne beschattende und samenspendende Laubbäume, Lärchen und überlebende Fichten innerhalb der großen Befallsflächen zurückzuführen ist.

Durch die Störung und die nachfolgende Verjüngung kam es zu einer Erhöhung der strukturellen Diversität - auf Bestandes- als auch auf Landschaftsebene. Die Auswertung des Aggregationsindex $(R)$ von Clark und Evans (1954) bestätigte ein geklumptes Aufwachsen der neuen Bestandesgeneration im Gegensatz zu den zuvor stockenden Fichtenaltbeständen auf Bestandesebene (Tabelle 3.2). Die räumliche Heterogenität verschiedener Jungwuchsdichten und Kronenschlussgrade zeichnete ein ähnliches Bild auf Landschaftsebene (Tabelle 4.2). Ungleiche räumliche Verteilungen der Bestandesglieder sind ein typisches Merkmal seit langem ungenutzter, spätsukzessionaler alter Wälder (old-growth forests, Bauhus et al. 2009). Dieser Vergleich ist in diesem Fall jedoch nur eingeschränkt zulässig, da Fichtenaltbestände und frühsukzessionale Stadien unterschiedliche Bestandesalter abbilden und davon auszugehen ist, dass sich die räumlichen Bestandesstrukturen im Verlauf des Bestandeslebens stetig weiter verändern (Zenner 2000, Franklin et al. 2002). Dennoch lassen geklumpt aufwachsende Jungwuchsbestände und heterogene Jungwuchsdichten eine vielfältigere Bestandesentwicklung und damit einhergehend auch größere Habitatdiversität erwarten als gleichmäßig bestockte Jungwuchsbestände (Donato et al. 2012).

Entgegen der, auch in der Diskussion von Kapitel 3 formulierten Erwartung und bisheriger Erkenntnisse der Verjüngungsdynamik nach Störungsereignissen (Bauer 2002, Rammig et al. 2006, El Kateb et al. 2006, Wild et al. 2014), bestand der Großteil der 2012/13 aufgenommenen Jungwuchsindividuen nicht aus Vorausverjüngung, sondern war erst nach dem Störungsereignis 
gekeimt (siehe Abb. 2.7). Aufgrund der angewandten Methode der Triebinternodienzählung zur Altersbestimmung kann eine Abweichung zwischen ermitteltem und tatsächlichem Alter um bis zu fünf Jahre nicht ausgeschlossen werden (Batllori und Guitérrez 2008). Doch selbst ein Sicherheitszuschlag von fünf Jahren auf die ermittelten Baumalter stellt das Ergebnis, dass die Mehrheit des vorhandenen Jungwuchses erst nach dem Störungsereignis gekeimt ist, nicht in Frage. Ein Grund für die größere Bedeutung der Vorausverjüngung in anderen Untersuchungen, u.a. im Nationalpark Bayerischer Wald (Bauer 2002, Zeppenfeld et al. 2015), mag in der dortigen größeren Flächenausdehnung des Borkenkäferbefalls (Lausch et al. 2011) und den damit verbundenen extremeren Lückenbedingungen und einer mangelnden Samenverfügbarkeit liegen. Gleichzeitig spielt der Bergahorn mit effektiver Samenverbreitung und großen jährlichen Höhenzuwächsen, die ein zügiges Überwachsen der Bodenvegetation und verbissgefährdeter Höhen ermöglichen, in den kalkalpinen Bergwäldern des Nationalparks Berchtesgaden eine deutlich größere Rolle als in den silikatgeprägten Beständen des Bayerischen Waldes. Dort steht im Wesentlichen nur die Vogelbeere als vergleichbare Pionierbaumart zur verfügung (Jehl 2001). Langjährige Untersuchungen in zahlreichen durch Vivian/Wiebcke 1990 und Lothar 1999 verursachten Windwürfen in der Schweiz (Brang et al. 2015, Wohlgemuth und Kramer 2015) stützen die Ergebnisse dieser Studie über den geringen Anteil der Vorausverjüngung an der erfolgreichen natürlichen Verjüngung nach Störungen im Bergwald.

Tatsächlich wiesen die untersuchten Fichtenaltbestände vergleichbar hohe Jungwuchsdichten an kleinem (0-20 cm Höhe) und mittelgroßem Jungwuchs (20-50 cm Höhe) auf, wie die Bestände des fortgeschrittenen frühsukzessionalen Stadiums (Abb. 2.5). Wenn man davon ausgeht, dass dies weitgehend den Bedingungen entspricht, die vor dem Borkenkäferbefall vor 17-25 Jahren die Bestände des heutigen fortgeschrittenen frühsukzessionalen Stadiums kennzeichneten, stellt sich die Frage, was in den vergangen zwei Jahrzehnten zum Absterben dieses Jungwuchses geführt hat, so dass er 2012/13 kaum mehr nachzuweisen war. Im Verlauf der letzen zwei Jahrzehnte wurden die Abschusszahlen von Rot-, Reh- und Gamswild im Nationalpark Berchtesgaden deutlich erhöht (Roland Baier, NPV Berchtesgaden, mündliche Mitteilung April 2012). Vermutlich waren die Verjüngungsbedingungen vor 20 Jahren, was den Verbissdruck durch Schalenwild angeht daher auch deutlich widriger als zum Zeitpunkt der Aufnahmen. Durch die Methodik der unechten Zeitreihe dieser Studie lassen sich Verluste des Jungwuchses im Verlauf der Sukzession weder widerlegen noch nachweisen. Aufgrund der generell im Nationalpark zunehmenden Jungwuchsdichten zwischen der zweiten (1995-1997) und dritten Waldinventur des Nationalparks Berchtesgaden (2010-2012, Winter und Becker 2015) ist aber davon auszugehen, dass sich die Verjüngungsbedingungen in den letzten Jahrzehnten im Gebiet wesentlich verbessert haben. Es erscheint wahrscheinlich, dass diese auf die geänderte Jagdpolitik und die damit einhergehenden reduzierten Schalenwildbestände 
zurückzuführen sind. Die Ergebnisse der Verjüngungsdynamik nach Borkenkäferbefall bestätigen damit die bekannte Annahme, dass Waldökosysteme bei angepassten Wildbeständen eine große Resilienz nach Störungen aufweisen können (Pellerin et al. 2010, Heinze et al. 2011), und diese Einschätzung allem Anschein nach auch bei geringer Vorausverjüngung in den Ausgangsbeständen zutrifft.

Die Erwartung, dass die Keimung von Gehölzen nach dem Störungsereignis auf bestimmte, der Keimung förderliche Kleinstandorte beschränkt wäre (z.B. erhöhte und geschützte Positionen mit reduzierter Konkurrenz und ausgeglichenen Feuchtigkeitsverhältnissen), ließ sich durch die Ergebnisse nur eingeschränkt bestätigen. Die Bedeutung des Totholzes als Wuchssubstrat nahm besonders in den hochmontanen Beständen von den Fichtenaltbeständen zum fortgeschrittenen frühsukzessionalen Stadium zu (Abb. 2.4). Die Mehrheit des 20 Jahre nach dem Störungsereignis aufgekommenen Jungwuchses war jedoch nicht an besonderen, sicheren Wuchsorten, sondern in der Streu-, Moos- und auch Krautschicht zu finden. Dies steht in scheinbarem Widerspruch zu der mehrfach belegten zentralen Bedeutung des Totholzes für die Naturverjüngung der Fichte in (Mittel-) Gebirgslagen (z.B. Jehl 2001, Meyer und Petersen 2003, Jonášová und Prach 2004, Kupferschmid und Bugmann 2005, Baier et al. 2007, Keidel et al. 2008). Ein für die Keimung günstiger Zersetzungsgrad des Totholzes ergibt sich in höheren Lagen etwa 30 bis 60 Jahre nach Bestandeszusammenbruch (Zielonka 2006), mit mehrjähriger Verzögerung bei Stehendbefall und zeitversetztem Zusammenbruch des Totholzes (Storaunet und Rolstad 2002). Es wird daher erwartet, dass die Bedeutung des Totholzes als Keim- und Wuchssubstrat im Untersuchungsgebiet, besonders in den höheren Lagen, in den nächsten Jahrzehnten weiter zunehmen und damit auch die Jungwuchsdichten in diesen Lagen weiter erhöhen wird. Untersuchungen in BorkenkäferBefallsflächen und Windwürfen in der Schweiz über die Effektivität von stehendem und liegendem Totholz als Schutz gegen Naturgefahren, besonders Schneegleiten und das Anreißen von Lawinen, haben gezeigt, dass ein effektiver Schutz durch Totholzobjekte 20 bis 30 Jahre auf den Flächen gegeben sein kann (Kupferschmid Albisetti et al. 2003, Bebi et al. 2015). Bei erfolgreicher Naturverjüngung, die nach etwa 30 Jahren die Schutzwirkung übernehmen kann, kommt es damit zu einer weitgehend lückenlosen Lawinenschutzwirkung in den gestörten Beständen (Kupferschmid Albisetti et al. 2003, Bebi et al. 2015). Dem nach Störungen im Bestand verbleibenden Totholz ist damit im Bergwald zusätzlich zur Wirkung als Wuchssubstrat und für den Humuserhalt bzw. -aufbau (Baier 2006), ein weiter wesentlicher Einfluss auf eine erfolgreiche Naturverjüngung zuzuschreiben.

Die Höhe und Deckung der Bodenvegetation, die Höhenstufe und die Entfernung der Samenbäume wurden als wesentlichste Einflussfaktoren auf die Artenzusammensetzung des Jungwuchses in dieser Studie identifiziert (Abb. 2.6). Es ist kaum erforscht, inwieweit sich das großflächige Absterben eines 
Altbestandes nicht nur auf die Samenverfügbarkeit, sondern auch auf die Mykorrhizierung der nachfolgenden Baumgeneration auswirkt und wo die diesbezüglich kritischen Befallsflächengrößen liegen (Peter et al. 2013). Einzelne überlebende Altbäume und Naturverjüngungspflanzen scheinen die Wahrscheinlichkeit einer erfolgreichen Mykorrhizierung der aufkommenden Naturverjüngung jedoch zu erhöhen (Baier 2006, Peter et al. 2013). Die Samenverfügbarkeit für die Fichte war auf den kleinen Befallsflächen dieser Studie aufgrund des nahen Bestandesrandes und auch einzelnen überlebenden Altbäumen innerhalb der Befallsfläche kein limitierender Faktor für die Verjüngung (Tabelle 2.2). Die weiteren Hauptbaumarten des natürlichen Bergmischwaldes der nördlichen Kalkalpen - Europäische Buche und Weißtanne (Walentowski et al. 2006) - waren hingegen nur in wenigen Fällen als Samenbaum in der Nähe der Befallsflächen zu finden, was sich auch in den geringen Anteilen dieser beiden Baumarten im Jungwuchs widerspiegelte (Tabelle 2.2 und 2.3). Gleichzeitig konnten auch auf etwa 65 \% der Flächen auf denen entsprechende Samenbäume in unmittelbarer Nähe zu finden waren keine Naturverjüngung der Tanne und Buche beobachtet werden. Dies verstärkt die Annahme, dass verstärkter Verbiss durch Schalenwildarten die Beteiligung von Buche und Tanne in der nächsten Baumgeneration gegenüber der Gemeinen Fichte zusätzlich erschweren wird (Ammer 1996a, Motta 1996, Prietzel und Ammer 2008, Klopcic et al. 2010). Mit einer natürlichen Rückwanderung von Europäischer Buche und Weißtanne in die Bestände ist daher auch, bei für diese Baumarten tendenziell günstigeren Verjüngungsbedingungen unter Schirm (Otto 1994), eher im Laufe der nächsten Jahrhunderte als im Laufe der nächsten Jahrzehnte zu rechnen (Küßner 1997, Diaci 2002). Eventuell kann eine Rückkehr der großen Beutegreifer in die Bergwälder diese Entwicklung durch die Reduktion des Verbissdrucks in manchen Fällen beschleunigen. Die Anteile der Gemeinen Fichte waren in der Bestockung 20 Jahre nach dem Borkenkäferbefall im Vergleich zu den Fichtenaltbeständen bereits deutlich reduziert. Auch wenn davon auszugehen ist, dass die hohe Beteiligung der eher lichtbedürftigen Arten Bergahorn und Vogelbeere mit fortschreitender Sukzession wieder abnehmen wird (Hein et al. 2009, Höllerl und Mosandl 2009), ist dennoch ein erheblicher Einfluss des derzeitig hohen Laubbaumartenanteils auf Bestandesklima, Humusform und Habitatbedingungen und damit auch auf die Artenzusammensetzung verschiedener Artengruppen zu erwarten. 


\section{Veränderung der Biodiversität}

Borkenkäferbefall stellt gemeinsam mit Sturmereignissen das natürliche Störungsregime mitteleuropäischer Fichtenwaldökosysteme dar (Svoboda et al. 2012), und die Mehrzahl der heute in temperierten Fichtenwäldern vorzufindenden Arten scheint sich durch Anpassung an die natürlichen Störungsregime der Vergangenheit entwickelt zu haben (Sousa 1984, Bengtsson et al. 2000). In den hochmontanen Lagen des Untersuchungsgebiets mit natürlicherweise weitgehend reinen Fichtenwäldern ist davon auszugehen, dass die Störungen durch den Borkenkäferbefall dem natürlichen Störungsregime entsprechen und die Artengemeinschaften an abrupte Bestandesveränderungen angepasst sind. Ein Teil der Arten von Fichtenwaldökosystemen scheint auf die temporär lichten und totholzreichen Bedingungen nach Störungen geradezu angewiesen zu sein und von diesen zu profitieren (Müller et al. 2008, Svoboda et al. 2012). Durch die einzelbaum- bis truppweise Mischung von Europäischer Buche, Weißtanne und Gemeiner Fichte der natürlicherweise in den unteren und mittleren Lagen des Untersuchungsgebiets stockenden Bergmischwälder, ist ein natürlicher großflächiger Einfluss des Borkenkäferbefalls in diesen Wäldern eher unwahrscheinlich. Dennoch haben Untersuchungen in slowenischen Bergmischwäldern gezeigt, dass auch diese natürlicherweise periodisch durch mittelstarke Sturmereignisse beeinflusst wurden (Nagel et al. 2007, Firm et al. 2009), und deren Artengemeinschaften damit vermutlich an vergleichbare Störungsbedingungen mit temporären Öffnungen und starker Totholzanreicherung angepasst sind.

\section{Gefäßpflanzen}

Es ist bekannt, dass die Artenvielfalt der Bodenvegetation von Waldökosystemen durch zunehmenden Lichteinfall in der Regel ansteigt (Ammer 1996b) und dass die vermehrte Lichtverfügbarkeit in frühsukzessionalen Stadien lichtbedürftige Arten begünstigt (Holeska 2003, Lehnert et al. 2013). Erhöhte Mineralisationsraten in den ersten Jahren nach Borkenkäferbefall verstärken lokal die Nitrat-Verfügbarkeit $\left(\mathrm{NO}_{3}{ }^{-}\right.$, Huber 2005) und fördern stickstoffliebende Pflanzenarten (Sayer und Reif 1998, Ewald et al. 2011). Der Borkenkäferbefall im Nationalpark Berchtesgaden und die nachfolgende Sukzession erhöhten die Artenvielfalt der Gefäßpflanzen sowohl in der Kraut- als auch in der Strauchschicht und veränderten die Artenzusammensetzung zugunsten licht- und nährstoffliebender Pflanzenarten (siehe Abb. 3.3 und Tabelle 3.4). Auch zwanzig Jahre nach dem Störungsereignis war noch kein Rückgang dieser Entwicklung erkennbar. Die Begünstigung der licht- und nährstoffliebenden Pflanzenarten war hauptsächlich als Änderung der Dominanzverhältnisse nachweisbar. Die große Überlappung der Artengemeinschaften der drei Sukzessionsstadien in der NMDS-Ordination zeigte, dass es bei den Gefäßpflanzen durch die Störung zu einer Erweiterung der Artengemeinschaft auf Alpha-Diversitätsebene, nicht aber zu einer starken Änderung der Artenzusammensetzung kam (Abb. 4.3). Dies scheint insofern nachvollziehbar, als dass 
es durch den Stehendbefall des Borkenkäfers zu keiner direkten Veränderung der Waldbodenbedingungen kommt (Roberts 2004, Jonášová und Prach 2008). Die Veränderung der Strahlungsverhältnisse führt zu einer Begünstigung der licht- und nährstoffliebenden Pflanzenarten, die vereinzelt und in geringer Artmächtigkeit aber auch schon in lichteren Bereichen einzelner Fichtenaltbestände zu finden waren. Eine Störung der Bodenoberfläche durch Windwurf, Lawinenabgänge oder Räumung kann hingegen, zumindest temporär, zu einer deutlicheren Erweiterung der Artengemeinschaft der Gefäßpflanzen führen (Kupferschmid Albisetti 2003, Fischer und Fischer 2009, Bohner et al. 2010, Ewald et al. 2011, Fischer et al. 2012) und eine größere Dominanz der Pionierbaumarten Weide (Salix spp.) und Aspe (Populus tremula L.) in der nachfolgenden Sukzession auslösen (Jehl 2001, Fischer und Fischer 2009). Im Gegensatz zu der Dynamik auf einer durch Vivian/Wiebcke 1990 verursachten Windwurffläche im Untersuchungsgebiet (Klausbachtal) mit wesentlicher Beteiligung der genannten Pionierbaumarten an der Naturverjüngung (Konnert und Siegrist 2000), waren diese auf den Borkenkäfer-Befallsflächen nur selten als Einzelindividuen zu finden.

\section{Epigäische Tierartengruppen}

Entgegen der eingangs erwähnten Hypothese führte die Veränderung der Bodenbedeckung durch Borkenkäferbefall und nachfolgende Sukzession kaum zu einer Änderung der Artenvielfalt der bodenbesiedelnden (epigäischen) Arten der Käfer (Coleoptera), Spinnentiere (Arachnida), Mollusken (Mollusca) und Springschwänze (Collembola, siehe Abb. 3.3). Kenter et al. (1998.) wiesen durch erhöhte Strukturvielfalt auf Windwurfflächen eine Zunahme der Abundanzen und Artenzahlen epigäischer Käferfamilien (Carabidae und Staphilinidae) im Vergleich mit angrenzenden Fichtenaltbeständen nach. Mit zunehmender Deckung der Bodenvegetation gingen Artenzahlen und Abundanzen wieder zurück (Kenter et al. 1998) und erreichten bei den Laufkäfern (Carabidae) nach sechs Jahren wieder weitgehend das Niveau und die Artenzusammensetzung der ungestörten Artengemeinschaft (Fischer 1998).

Bisherige Studien haben ergeben, dass sich die Artenvielfalt von Spinnentieren sowohl durch eine Abnahme der Kronenüberschirmung (Vierling et al. 2011) als auch durch zunehmende Artenvielfalt der Bodenvegetation erhöhen kann (Mrzljak und Wiegleb 2000). Die Störungsflächen der vorliegenden Untersuchung waren durch beide Bedingungen - geringe Kronenüberschirmung und hohe Pflanzenvielfalt - geprägt und deuteten einen Anstieg der Artenvielfalt der Spinnentiere an. Dieser Anstieg war jedoch nicht statistisch signifikant.

Begünstigende Einflussgrößen der Artenvielfalt von waldbesiedelnden Mollusken sind Temperatur, Bestandesalter, Baumhöhe, stärker zersetztes Totholz, Gefäßpflanzenvielfalt und Diversität der 
Habitatbedingungen (Barker und Mayhill 1999, Aubry et al. 2005, Müller et al. 2005, Müller et al. 2009, Rieger et al. 2010). Während die untersuchten Fichtenaltbestände durch höhere Bestandesalter und Baumhöhen, aber geringere Totholzvolumina und Artenzahlen der Gefäßpflanzen gekennzeichnet waren, zeigten die störungsbeeinflussten frühsukzessionalen Bestände die gegenteiligen Charakteristika. Im Verlauf von Störung und Sukzession kam es zu einer Veränderung der Mollusken-Artengemeinschaft, die sich aber nicht in veränderten Artenzahlen niederschlug. In ähnlicher Weise konnten auch Spelda et al. (1998) in ihrer Untersuchung der Molluskenfauna auf Windwurfflächen im Muschelkalkgebiet Südwestdeutschlands keine Veränderung der Artenvielfalt im Vergleich mit angrenzenden Fichtenaltbeständen nachweisen.

Springschwänze scheinen sowohl von einer Anreicherung von Totholz und Nadelstreu (Ulyshen et al. 2011) als auch von einer artenreichen Krautschicht zu profitieren (Salamon et al. 2008). Die Artenvielfalt der Springschwänze wies in dieser Untersuchung ihr Maximum im beginnenden frühsukzessionalen Stadium auf, das durch das Absterben der Fichtenaltbestände durch hohe Totholzvolumina und Streumengen gekennzeichnet war. Die Artenvielfalt der Springschwänze war jedoch signifikant negativ mit der zunehmenden Höhe der Bodenvegetation korreliert (siehe Tabelle 3.3). Dies mag gemeinsam mit der ausbleibenden Nachlieferung an Nadelstreu deren Rückgang im fortgeschrittenen frühsukzessionalen Stadium erklären.

\section{Phytophage und bestäubende Insekten}

Die begünstigenden Bedingungen des fortgeschrittenen frühsukzessionalen Stadiums für die phytophagen (pflanzenfressenden) und bestäubenden Insekten zeigten sich zum einen an den hohen Artenzahlen und zum anderen an der großen Anzahl an Indikatorarten in diesem Stadium (Abb.3.3 und Tabelle 3.4). Von den untersuchten funktionellen Gruppen reagierten diese beiden Gruppen gemeinsam mit den Gefäßpflanzen am deutlichsten auf das Absterben des Fichtenaltbestandes auf Alpha-Diversitätsebene. Möglicherweise hängt dies mit dem Anstieg der spezifischen Blattfläche (specific leaf area, SLA) durch ein Nebeneinander an Nadel- und Laubgehölzen in den frühsukzessionalen Stadien zusammen, das zu einer Förderung der Konsumenten führen kann (Campbell und Donato 2014). Der Zusammenhang zwischen Primärproduktion und Konsumenten zeigt sich auch in dem gleichläufigen Anstieg von Blütenpflanzen und Bestäubern im Verlauf der durch den Borkenkäfer initiierten Sukzession. Die durch den Borkenkäfer verursachten Waldinnenränder mit erhöhter Strahlungsbilanz können neben Käfern, Wanzen, Stechimmen und Florfliegen (Müller et al. 2007) zahlreiche weitere lichtbedürftige Arten verschiedenster Taxa und Entwicklungsgeschichten zumindest temporär begünstigen (Lehnert et al. 2013). 


\section{Totholzbesiedelnde Arten}

Durch Borkenkäferbefall verursachte große Mengen an Fichtentotholz und Strahlung haben einen positiven Effekt auf die Abundanzen xylobionter (totholzbesiedelnder) Käferarten, besonders unter den Generalisten und den auf Nadelholz spezialisierten Gilden (Müller et al. 2008, 2010). Durch die abnehmende Nährstoffverfügbarkeit im Verlauf der Totholzzersetzung reduziert sich die Attraktivität des Totholzes (besonders des Nadelholzes; Saint-Germain et al. 2007) für xylobionte Käfer im Verlauf der Zersetzung (Kopf und Funke 1998). In Übereinstimmung mit den Ergebnissen war auch in dieser Studie im beginnenden frühsukzessionalen Stadium die höchste Artenvielfalt derjenigen xylobionten Käfer zu finden, die frühe Zersetzungsstadien des Holzes präferieren (Abb. 3.3). Im fortgeschrittenen frühsukzessionalen Stadium scheint das Totholz den günstigen Zersetzungszustand für diese Arten bereits überschritten zu haben, während es für die Arten der reifen Zersetzungsstadien noch nicht weit genug zersetzt war. Gleichzeitig unterschied sich die Artenzusammensetzung der xylobionten Käfer im fortgeschrittenen frühsukzessionalen Stadium deutlich von jener der beiden vorhergehenden Stadien und wies eine erheblich größere Beta-Diversität auf Landschaftsebene auf (Abb. 4.3 und Tabelle 4.2). Während die Pilze mit abnehmender Beta-Diversität die abnehmende Heterogenität der Totholzersetzungsgrade widerzuspiegeln scheinen (siehe nächster Abschnitt), wird die Diversität der xylobionten Käferarten vermutlich von nicht erfassten Struktur-, bzw. Totholzparametern beeinflusst. Möglicherweise spielten hier, wie in einer Gefährdungsanalyse der Käferfauna Deutschlands ermittelt (Seibold et al. 2014), unterschiedliche Besonnungsverhältnisse des Totholzes eine wesentliche Rolle.

Die Artenvielfalt totholzbesiedelnder Pilze hängt, nach den Ergebnissen etlicher Studien, an der Menge und Vielfalt des zur Besiedlung verfügbaren Totholzes (Sippola und Renvall 1999, Küffer und Senn-Irlet 2005, Lonsdale et al. 2008, Bässler et al. 2010, 2012, 2015). Auch wenn die Totholzmengen durch den Borkenkäferbefall im Nationalpark Berchtesgaden erheblich zugenommen haben, war dies für die Vielfalt der Totholzobjekte nicht nachzuweisen (Tabelle 4.2). Zum einen unterblieb auf den Störungsflächen die stetige Nachlieferung an Feinmaterial, wie Äste und Zweige (fine woody debris, FWD), die eine andere Artengemeinschaft tragen als dicke Totholzobjekte (coarse woody debris, CWD, Heilmann-Clausen und Christensen 2004, Bässler et al. 2012). Zum anderen führte der einheitliche Absterbezeitpunkt durch den Borkenkäferbefall zu relativ einheitlichen Zersetzungsgraden auf den Störungsflächen, während die einzelnen in den Fichtenaltbeständen aufgenommen Totholzobjekte durch individuelle Absterbezeitpunkte heterogenere Habitatbedingungen für die totholzbesiedelnden Pilze zur Folge hatten. Dies mag die gleichbleibenden Artenzahlen auf Alpha-Diversitätsebene und die abnehmende Beta-Diversität der Artenzusammensetzung im Verlauf der Sukzession erklären. Durch das räumliche Mosaik der 
verschiedenen Sukzessionsstadien auf Landschaftsebene erhöht sich die Gamma-Diversität des Gebiets, was die abweichende Artenzusammensetzung auf den Störungsflächen im Vergleich zu den Fichtenaltbeständen verdeutlicht (Abb. 4.3 und Tabelle 4.S11). Die große Differenz zwischen erfassten und extrapolierten Artenzahlen und die ungesättigten Artenakkumulationskurven weisen jedoch auch auf eine unzureichende Erfassungsintensität der totholzbesiedelnden Pilze in dem sehr artenreichen Untersuchungsgebiet der Berchtesgadener Alpen hin (Abb. 3.4, Falkner 1997, Gotelli und Colwell 2001, Magurran 2004). Dies mag zum einen auf die einmalige Aufnahmekampagne im Herbst 2013 zurückzuführen sein, und zum anderen an der alleinigen Erfassung der Fruchtkörper liegen. Durch Gewinnung von Holzproben und Untersuchung, auf deren zum Zeitpunkt der Aufnahmen nicht fruchtkörperbildenden Arten, wäre eine vollständigere Erfassung der totholzbesiedelnden Pilze zu erwarten (Honold und Oberwinkler 1998, 1999). Diese wurde jedoch aus organisatorischen Gründen nicht durchgeführt.

Durch die fortschreitende Zersetzung jedes Totholzobjektes und der damit verbundenen stetigen Veränderungen der Habitatbedingungen ist Totholz ein dynamisches Habitat, dessen Kontinuität z.B. für Insekten und Pilzarten von der kontinuierlichen Bereitstellung frischen Totholzes abhängt (Kraus et al. 2013). Dies ist durch Störungsereignisse mit zeitlich einheitlichem Absterben der Baumschicht, zumindest lokal, nicht gegeben, wie in dieser Studie durch den Mangel an Feinreisig (FWD) bei den Pilzartengemeinschaften bereits zu erkennen war. Die Bedeutung von Totholz als Einflussfaktor xylobionter Artengemeinschaften nimmt nach Kraus und Krumm (2013) mit zunehmendem räumlichem Maßstab zu. Ein Mosaik verschiedenster Sukzessionsstadien in unmittelbarer Nachbarschaft, wie sie durch den zerstreuten Borkenkäferbefall in dem untersuchten Prozessschutzgebiet verursacht wurden, ermöglicht daher eine gewisse Habitatkontinuität zumindest auf Landschaftsebene. Gleichzeitig führt das kleinbestandesweise Absterben der Fichtenbestände zu Totholzvolumina, die auch die Schwellenwerte von sehr anspruchsvollen Arten lokal überschreiten und den Erhalt von Populationen sehr seltener Arten fördern können (Müller und Bütler 2010). 


\section{Einfluss von Flächenräumung und unterstützender Pflanzung}

Aufgrund der überwiegend schattseitigen montanen Lage des Maßnahmenbereichs Borkenkäferbekämpfung im Nationalpark Berchtesgaden und dem Fehlen einer größeren Anzahl an Vergleichsflächen außerhalb des Maßnahmenbereichs Borkenkäferbekämpfung, basiert diese Auswertung auf dem Vergleich von nur sechs Borkenkäfer-Befallsflächen der beginnenden Sukzession mit Flächenräumung und Pflanzung innerhalb, mit sechs Borkenkäfer-Befallsflächen der beginnenden Sukzession ohne Maßnahmen außerhalb des Maßnahmenbereichs Borkenkäferbekämpfung. Für die Auswertung der Artdaten der faunistischen Artengruppen und der Pilze, die aufgrund organisatorischer Restriktionen generell nur auf der Hälfte der Probeflächen erhoben wurden, standen nur drei Vergleichspaare zur Verfügung. Die Ergebnisse und folgende Diskussion können daher nur einer ersten vorläufigen Einschätzung dienen, der weitere und intensivere Aufnahmen für diese Fragestellung folgen müssen.

Bei vergleichbarer Lückengröße wiesen die geräumten Flächen innerhalb des Maßnahmenbereichs Borkenkäferbekämpfung in der Tendenz höhere Anteile an direkter Strahlung auf (siehe Abb. 5.6). Dies korrespondiert mit den geringeren Volumina des lebenden und stehenden toten Bestandes auf diesen Flächen und schafft, bei gleichbleibender Konkurrenzsituation durch die Bodenvegetation, begünstigende Lichtverhältnisse für die natürliche Verjüngung dieser Störungsflächen (Ammer 1996b). Gleichzeitig scheint die Kahlflächensituation mit reduzierter Oberflächenrauigkeit und damit geringerer Reduzierung der Windgeschwindigkeiten tendenziell zu geringeren mittleren Jahrestemperaturen und durch verstärkte Erwärmung am Tag und gleichzeitig erhöhter Wärmeabstrahlung in der Nacht zu größeren Schwankungen zwischen Tages- und Nachtemperaturen zu führen (Abb. 5.6). Dies kann die Spätfrostgefahr erhöhen (Otto 1994), was durch die überwiegende Hanglage des Maßnahmenbereichs Borkenkäferbekämpfung und dem damit wahrscheinlichen Abfluss möglicher Kaltluftströme jedoch als unwahrscheinlich einzustufen ist. Gleichzeitig sind diese Unterschiede in den klimatischen Verhältnissen eine mögliche Erklärung für die unterschiedliche Artenzusammensetzung mancher Artengruppen innerhalb und außerhalb des Maßnahmenbereichs Borkenkäferbekämpfung.

Der Borkenkäferbefall lag zum Zeitpunkt der Aufnahmen auf den einzelnen Flächen 2-5 Jahre zurück. Bei den Jungwuchsdichten war kein signifikanter Unterschied zwischen den beiden Managementvarianten zu sehen, bei tendenziell höheren Individuenzahlen auf den ungeräumten, unbepflanzten Flächen (Abb. 5.7). Ein Teil des zum Zeitpunkt der Störung eventuell bereits im Maßnahmenbereich Borkenkäferbekämpfung vorhandenen Jungwuchses wurde möglicherweise auch durch die Räumung der Bestände geschädigt. Nach derzeitigem Kenntnisstand scheint das durchgeführte Management mit Räumung und Pflanzung daher nicht zu einem zügigeren 
Lückenschluss der Befallsflächen durch den Jungwuchs zu führen. Europäische Buche und Weißtanne, die natürlicherweise einen Großteil der montanen Bergmischwälder prägen würden (Walentowski et al. 2006), wurden in ihren Anteilen durch die Pflanzmaßnahmen allerdings deutlich erhöht (Abb. 5.8). Die im Anschluss an den Borkenkäferbefall in der Managementzone gepflanzten Jungpflanzen von Buche und Tanne befanden sich zum Zeitpunkt der Aufnahmen zum Großteil noch im mittelgroßen Jungwuchs, mit Höhen zwischen $20-50 \mathrm{~cm}$. Auch wenn derzeit im höheren Aufwuchs (50-200 cm) noch keine wesentlichen Unterschiede im mittleren Buchenanteil zwischen Beständen innerhalb und außerhalb des Maßnahmenbereichs Borkenkäferbekämpfung zu sehen waren, wird der Anteil der Buche wie auch der Tanne bei gleichbleibenden oder absinkenden Wilddichten im Maßnahmenbereich mittelfristig höher sein als außerhalb. Durch das Belassen des Totholzes auf den Flächen war kein schützender Effekt gegenüber Wildverbiss zu erkennen; beide Managementvarianten wiesen vergleichbare Anteile mit Terminaltriebverbiss von knapp $50 \%$ auf. Dies mag zum einen an dem im Stadium der beginnenden Sukzession noch überwiegend stehenden Totholzes liegen, und zum anderen an den hohen Schneehöhen im Gebiet, die die Erreichbarkeit der Triebspitzen trotz Totholzverhau bei verfestigter Schneedecke für das Wild dennoch ermöglichen (Odermatt und Wasem 2007). Darüber hinaus konnten durch Kupferschmid und Bugmann (2005) und Moser et al. (2008) auch beim Sommerverbiss und liegendem Totholz keine eindeutigen Unterschiede der Verbisssituation durch Gämse oder Rehwild zwischen geräumten und ungeräumten Beständen festgestellt werden.

Die untersuchten Artengruppen reagierten unterschiedlich auf die beiden Managementvarianten. Während Schnecken, Wanzen und die bestäubenden Käferarten mit signifikant höheren Artenzahlen auf den geräumten Flächen zu finden waren, wiesen totholzbesiedelnde Käferarten signifikant höhere Artenzahlen in den vom Management unbeeinflussten Beständen auf (Abb. 5.9). Die unterschiedlichen Artenzahlen der totholzbesiedelnden Käferarten bei signifikant unterschiedlichen Totholzmengen in den Beständen entspricht den Erwartungen aufgrund bisheriger Erkentnisse (u.a., Kopf und Funke 1998, Saint-Germain et al. 2007). Dennoch wiesen auch die geräumten Flächen mit einer mittleren Totholzmenge von knapp $60 \mathrm{fm} / \mathrm{ha}$ in Form der verbliebenen Stubben immer noch ein deutlich höheres Volumen auf als dies aus klassischen Wirtschaftswäldern bekannt ist (Müller und Bütler 2010, Priewasser et al. 2013). Aufgrund des bereits weiter fortgeschrittenen mittleren gewichteten Zersetzungsgrades der Stubben im Maßnahmenbereich Borkenkäferbekämpfung im Vergleich zu den stehenden und liegenen Stämmen außerhalb, scheint sich auch die Artenzusammensetzung der Totholzarten - der Käfer wie der Pilze - deutlich zu unterscheiden. Zu ähnlichen Ergebnissen kamen Duelli et al. (2002), die die faunitische Artengemeinschaften nach Windwürfen in geräumten und ungeräumten Beständen verglichen haben und zu einer Kombination beider Managementvarianten raten, um die Artenvielfalt durch ein Mosaik an Strukturen zu 
maximieren. Eine ähnliche Situation zeigte sich bei den epigäischen, also bodenbesiedelnden, Arten, die durch eine Kombination der beiden Managementvarianten unterschiedliche Feuchte- und Beschattungssituationen bei Vorhandensein bzw. Nicht-Vorhandensein von Totholz vorfanden (Abb. 5.10).

Eine globale Metaanalyse zum Einfluss von Flächenräumung nach natürlichen Störungen auf die Biodiversität solcher Flächen, in die auch die Ergebnisse dieser Teiluntersuchung eingeflossen sind, wies einen Anstieg der Artenzahlen totholzunabhängiger Artengruppen - Schnecken, Spinnen und Laufkäfern - nach (Thorn et al. eingereicht). Gleichzeitig war dort ein signifikanter Rückgang der Artenzahlen von totholzabhängigen Artengruppen - Moosen, Flechten, totholzbesiedelnden Pilzen, Vögeln, xylobionten Käfern und Springschwänzen - belegbar. Diese Veränderungen waren zum Großteil auf eine Reduktion der Totholzmengen zurückzuführen und wurden nur zu einem geringen Anteil durch eine geringere Heterogenität der Totholzbedingungen auf den geräumten Flächen erklärt (Thorn et al. eingereicht).

Durch das flächige Räumen der befallenen Fichten gehen, neben dem auf flachgründigen Humusstandorten kritisch zu bewertenden Kohlenstoff- und Nährstoffverlust (Harmon et al. 1986, Laiho und Prescott 2004, Baier 2006), wertvolle Kleinstandorte für die Verjüngung (Brang 1996, Bače et al. 2012) und Habitate für xylobionte Artengruppen verloren (Kopf und Funke 1998, Saint-Germain et al. 2007). Zusätzlich kommt dem Totholz eine wesentliche Schutzfunktion vor Schneebewegungen zu (Kupferschmid Albisetti et al. 2003, Bebi et al. 2015). Wissensdefizite bestehen noch beim Einfluss von großflächigen Störungsereignissen auf die Mykorrhizierung der Verjüngung. Für die Naturverjüngung kritische Flächenausdehnungen ergeben sich möglicherweise nicht nur durch eine Limitierung des Samenangebots, sondern auch durch fehlende Mykorrhizapartner nach großflächigem Absterben der Altbestände. Es hat sich aber gezeigt, dass sowohl einzelne überlebende Altbäume als auch bereits vorhandene Naturverjüngungspflanzen die Wahrscheinlichkeit einer erfolgreichen Mykorrhizierung der Naturverjüngung und damit auch die Überlebenswahrscheinlichkeit des Jungwuchses erhöhen können (Peter et al. 2013).

Im Gegensatz zu den Ergebnissen der vorliegenden Studie bescheinigten Pröll et al. (2015) den Bergwaldbeständen der österreichischen Kalkalpen auf südexponierten Windwurfflächen durch sehr geringe natürliche Jungwuchsdichten eine geringe Resilienz. Bei Flächen von Pröll et al. (2015) handelte es sich ausschließlich um geräumte Windwurfflächen. Priewasser et al. (2013) konnten hingegen in einer Untersuchung der Verjüngungsdynamik geräumter Windwurfflächen verschiedenster Expositionen in der Schweiz keinen wesentlichen Einfluss der Räumung auf die Naturverjüngung feststellen. 


\section{Resümee und Ausblick}

Auf Grundlage der wesentlichen Ergebnisse dieser Studie (siehe Tabelle 6.1 und Zusammenfassung), der vorhergehenden Diskussion und unter der Annahme vergleichbarer Rahmenbedingungen in den nächsten etwa 3 Jahrzehnten werden vorsichtig folgende weitere mittelfristige Entwicklungen der untersuchten Waldbestände im Nationalpark Berchtesgaden prognostiziert: Durch zunehmende Verjüngungsdichten wird es besonders auf der Mehrzahl der montanen Befallsflächen zu einer Verringerung des Strahlungseinfalls am Waldboden und damit voraussichtlich zu einer Reduktion der Artenvielfalt lichtliebender Arten in den Beständen kommen (Tabelle 6.1). In den hochmontanen und subalpinen Lagen wird mit zunehmender Zersetzung des Totholzes dessen Bedeutung als Keim- und Wuchssubstrat ansteigen und zu zunehmenden Verjüngungsdichten auch in diesen Lagen führen. Einhergehend mit dem Schließen der Lücken auf zahlreichen Befallsflächen ist mit einer abnehmenden horizontalen Bestandesheterogenität zu rechnen. Die bisherige Baumartenmischung aus Gemeiner Fichte, Bergahorn und Vogelbeere wird mit Rückgang der eher lichtbedürftigen Arten Bergahorn und Vogelbeere zu einer größeren Dominanz der Fichte führen. Dennoch wird auch mittelfristig eine, im Vergleich zu den Fichtenaltbeständen erhöhte strukturelle Vielfalt der FichtenLaubholzbestände prognostiziert. Auf Landschaftsebene wird durch zukünftige Störungsereignisse wie Windwurf, Borkenkäferbefall oder auch kleinräumige Seneszenz in den verbliebenden Fichtenaltbeständen in den nächsten Jahrzehnten eine weitgehende Habitatkontinuität frühsukzessionaler Stadien in den Bergwäldern des Prozessschutzgebietes erwartet (Tabelle 6.1).

Die Ergebnisse dieser Studie bestätigen die besondere Möglichkeit von Nationalparks als langfristige Lernorte der natürlichen (Wald)Dynamik für Wissenschaft, Umweltbildung und Öffentlichkeit. Die im Rahmen dieser Studie genutzten 140 Probeflächen der unechten Zeitreihe wurden als Dauerbeobachtungsflächen im Gelände angelegt, und ihre dauerhafte genaue Lokalisierung durch Erfassung der GPS-Koordinaten und durch Bodenmagnete sichergestellt. Die Temperaturlogger stehen weiterhin auf den Probeflächen und erweitern stetig die mesoklimatischen Zeitreihen. Ebenso wird die Entwicklung der Probeflächen im zweijährigen Turnus auch weiterhin standardisiert fotographisch erfasst und dokumentiert werden. Eine Wiederholungsaufnahme der Standort-, Bestandes- und Arterfassungen im Jahr 2022, zehn Jahre nach den Erstaufnahmen, würde detaillierte Aussagen einer echten zeitlichen, auch in den kommenden Jahrzehnten noch sehr dynamischen Entwicklung ermöglichen und einige der noch offenen Fragen dieser Studie beantworten können. Die Fortführung des Monitorings zur natürlichen Waldentwicklung nach Borkenkäferbefall im Nationalpark Berchtesgaden wird daher dringend empfohlen. 
Tabelle 6.1 Resümee der wesentlichen Ergebnisse dieser Studie (linke Spalte) und auf Grundlage vorhergehender Diskussion prognostizierte weitere mittelfristige Entwicklung von Standortparametern, Bestandesstrukturen, Verjüngung und Biodiversität im Verlauf der nächsten etwa drei Jahrzehnten (rechte Spalte).

Table 6.1 Summary of the main study results (left column) and predicted future medium-term development of site conditions, stand structures, regeneration and biodiversity in the next three decades (right column).

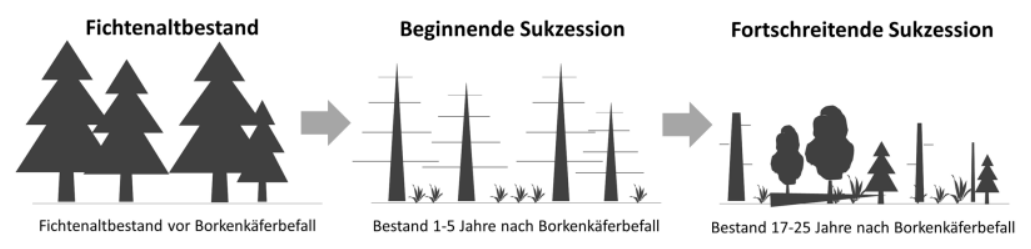

\section{Standort}

Durch den Borkenkäferbefall mit mittelgroßen Flächendimensionen und die nachfolgende Sukzession waren kein Humusabbau und keine signifikante Veränderungen des Mesoklimas nachzuweisen.

Die durch das Absterben des Kronendachs erhöhten Anteile an direkter Strahlung am Waldboden führten zu einer zunehmenden Deckung und Höhe der Bodenvegetation. Die erhöhten Strahlungswerte und die hohe Deckung der Bodenvegetation waren auch zwei Jahrzehnte nach dem Störungsereignis noch zu beobachten.

\section{Bestandesstruktur}

Durch das vom Borkenkäferbefall initiierte Absterben der Fichtenaltbestände reduzierten sich Bestandesvolumen und Kronenüberschirmung erheblich, bei gleichzeitig massiver Zunahme an stehendem Totholz. Große Anteile des stehenden Totholzes brachen bei fortschreitender Zersetzung im Verlauf der untersuchten etwa 20-jährigen Sukzession zusammen.

Der Borkenkäferbefall mit mittelgroßen Flächendimensionen und die nachfolgende Sukzession führten unter anderem durch das räumlich unregelmäßige Aufkommen des Jungwuchses zu einer erhöhten strukturellen Heterogenität auf Bestandes- und Landschaftsebene.

\section{Verjüngung}

Trotz der verstärkten Konkurrenzsituation mit der Bodenvegetation kam es zwei Jahrzehnte nach dem Borkenkäferbefall zu einer zügigen Verjüngung der Befallsflächen in montaner Lage. Hochmontan war diese Entwicklung verzögert zu beobachten.

Der Jungwuchs wurde von Gemeiner Fichte, Bergahorn und Vogelbeere dominiert. Die natürlichen Hauptbaumarten des Bergmischwaldes, Europäische Buche und Weißtanne, fehlten auf Grund der historischen Bewirtschaftung sowohl als Samenbäume als auch im Jungwuchs weitgehend.

Die überwiegende Mehrheit der Jungwuchsindividuen war nach dem Störungsereignis gekeimt und bestätigt damit eine große Resilienz der Bergwälder nach mittelgroßen Störungsereignissen unter der Voraussetzung angepasster Schalenwildbestände.

\section{Biodiversität}

Nach der Störung waren bei den untersuchten epigäischen Artengruppen keine Veränderungen (Käfer, Spinnentiere, Mollusken), bzw. ein Rückgang der Artenvielfalt (Springschwänze) aufgrund fehlender Streunachlieferung zu beobachten.

Die licht-, nährstoff- und totholzbedürftigen Arten profitierten von den temporären Lückenbedingungen und reagierten überwiegend mit einem Anstieg der Artenvielfalt im Verlauf der Sukzession. Dieser Anstieg war auch zwei Jahrzehnte nach dem Störungsereignis trotz zunehmender Verjüngungsdichten noch zu beobachten.

Die große Heterogenität der Bestandesstrukturen auf Landschaftsebene erhöhte die Gamma-Diversität des untersuchten Waldgebietes von totholzbesiedelnden Pilzen und Käfern.

\section{Prognostizierte weitere mittelfristige Entwicklung}

(etwa 3 Jahrzehnte)

\section{?}

Rückgang des Strahlungseinfalls am Waldboden mit Schließen der Lücken, besonders in montaner Lage. Damit einhergehend Reduktion der hohen Deckung der Bodenvegetation.
Abnahme der kleinräumigen Bestandesheterogenität mit Verringerung bestockungsfreier Flächen, besonders in montaner Lage.

Dennoch auch mittelfristig strukturreichere Fichten-Laubholzbestände als die Ausgangsbestände.

Weiterhin erhöhte strukturelle Heterogenität durch Mosaik an verschiedenen Sukzessionsstadien auf Landschaftsebene.

Weitere Zunahme der Verjüngungsdichten.

Zunehmende Bedeutung des Totholzes als Keim-/Wuchssubstrat in hochmontanen/ subalpinen Lagen mit fortschreitender Zersetzung.

Rückgang der Anteile von Bergahorn und Vogelbeere und zunehmende Dominanz der Gemeinen Fichte.

Rückgang der Vielfalt licht- und stickstoffliebender Arten mit Schließen der Lücken, besonders in montaner Lage auf Bestandesebene.

Veränderung der Artenzusammensetzung der totholzbesiedelnden Artengruppen mit fortschreitender Totholzzersetzung.

Habitatkontinuität auf Landschaftsebene durch Entstehen neuer Lücken durch erneuten Windwurf/Borkenkäferbefall oder Seneszenz der Fichtenaltbestände. 


\section{Schlussfolgerungen für die forstliche und naturschutzfachliche Praxis}

Aus den Ergebnissen lassen sich unter Berücksichtigung der vorhergehenden Diskussion folgende Schlussfolgerungen für die forstliche und naturschutzfachliche Praxis ableiten:

Bei entsprechender Störungsdynamik mit mittelgroßen Störungsflächen kann ein Prozessschutzgebiet nicht nur dem Erhalt von Arten dienen die Altholz- und Zerfallsstadien benötigen, sondern auch den Erhalt lichtbedürftiger Arten fördern. Um gleichzeitig die lokalen Populationen von jenen Artengruppen nicht zu gefährden, die mit einem Rückgang der Artenvielfalt auf die Störungen auf Bestandesebene reagieren, bedarf es ausreichend großer Schutzgebiete. Großflächige Prozessschutzgebiete scheinen durch natürliche Störungen, zumindest im kalkalpinen Bergwald, ein Mosaik verschiedenster Sukzessionsstadien und Bestandesstrukturen auf Landschaftsebene zu ermöglichen und können damit die GammaDiversität eines Waldgebietes erhöhen.

Die Entwicklung von strukturarmen sekundären Fichtenwäldern in Richtung strukturreicherer Bergmischwaldestände kann durch Störungen mit mittelgroßen Flächendimensionen beschleunigt werden. Unter der Voraussetzung angepasster Wildbestände weisen die im Gebiet stockenden Bergwälder bei mittelgroßen Störungsereignissen eine große Resilienz auf. Auch bei fehlender Vorausverjüngung in den Altbeständen lassen die Ergebnisse dieser Studie in den montanen Lagen ein zügiges Schließen der Bestandeslücken durch Naturverjüngung erwarten und bei ausreichenden Totholzvorräten erscheint auch in den hochmontanen Lagen eine erfolgreiche natürliche Verjüngung innerhalb weniger Jahrzehnte wahrscheinlich.

Bei mangelnden Samenbäumen von Europäischer Buche und Weißtanne in erreichbarer Nähe der Bestände kann auch nach Störungen nicht von einer wesentlichen natürlichen Beteiligung dieser Baumarten in den nächsten Baumgenerationen ausgegangen werden. Wo es im bewirtschafteten Bergwald das Ziel ist, die natürliche Baumartenzusammensetzung der Bergmischwälder kurzfristig wieder herzustellen, müssen Buche und Tanne künstlich eingebracht werden und die lokalen Schalenwildbestände im Hinblick auf das Überleben der Jungpflanzen angepasst werden.

Temporäre Bestandeslücken haben eine große Bedeutung für den Erhalt lichtbedürftiger Artengruppen in den Bergwaldökosystemen. Der Verzicht auf direkte Anpflanzungen, wo dies im Hinblick auf die Schutzwirkung gegenüber Naturgefahren vertretbar ist, ermöglicht durch das allmähliche Schließen der Bestandeslücken durch die Naturverjüngung Entwicklungsmöglichkeiten für lichtliebenden Artengruppen fortgeschrittener Sukzessionsstadien. 
Das Belassen von Totholz auf den Störungsflächen fördert vor allem langfristig, bei entsprechenden Zersetzungsgraden, als Keim- und Wuchssubstrat die natürliche Verjüngung in den hochmontanen und subalpinen Wäldern und erhält den Lebensraum xylobionter Arten. Zusätzlich erhält es die Schutzwirkung des Bergwaldes gegenüber Schneebewegung auf den Störungsflächen um bis zu 30 Jahre und ist besonders auf den flachgründigen Tangelhumusböden essentiell für den Erhalt der Humusvorräte in den Bergwäldern. Bei Konflikten mit Zielen des Waldschutzes besteht die Möglichkeit des Entrindens oder des Schlitzens der Rinde gefällter Bäume, wobei Letzteres sowohl aus Kostengründen als auch zum Erhalt wertvoller Habitatbedingungen als günstiger einzuschätzen ist (siehe auch Thorn et al. 2016).

Für die anstehende Waldentwicklungsplanung im Nationalpark Berchtesgaden wird der Nationalparkverwaltung empfohlen zur Förderung der Boden- und Objektschutzwirkung und der Biodiversität der Bergwaldbestände künftig keine aktive Holzentnahme im Rahmen des Waldumbaus außerhalb des Maßnahmenbereichs Borkenkäferbekämpfung zu planen. Stattdessen sollte das durch Durchforstungsmaßnahmen, ebenso wie durch natürliche Störungen, anfallende Holz in den Beständen verbleiben und Buche und Tanne durch Voranbau in geeignete Bestände und natürlich entstandene Lücken des Waldumbaubereichs eingebracht werden. 


\section{Verzeichnisse}

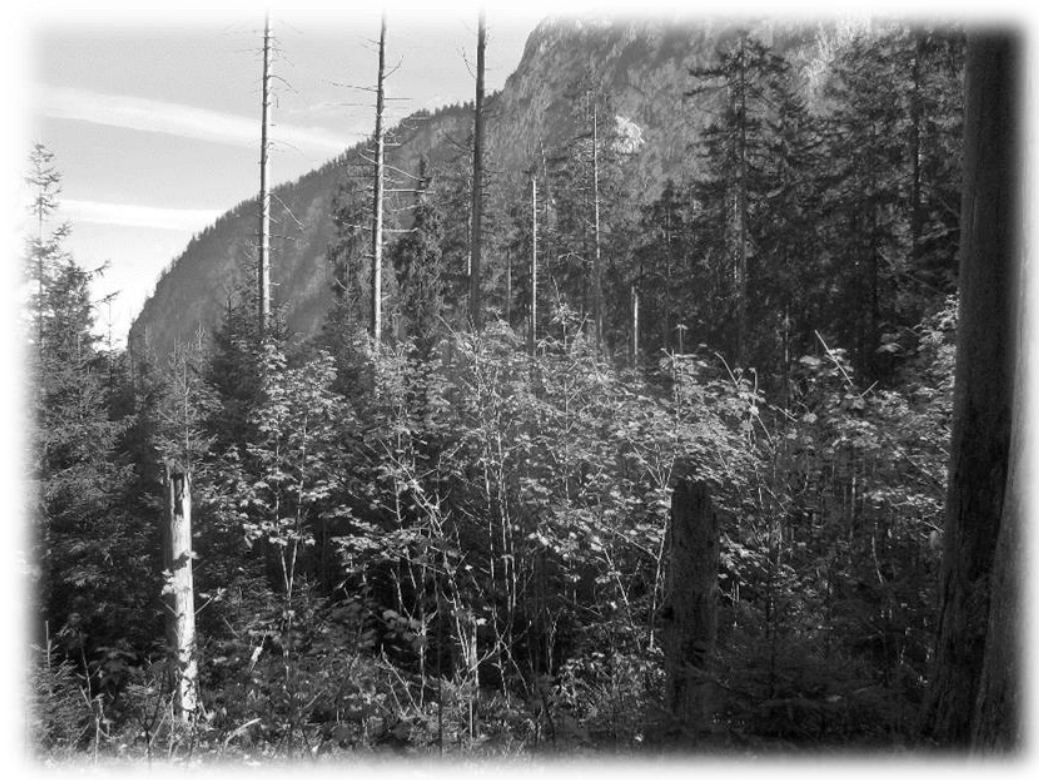

Stadium der fortschreitenden Sukzession mit Jungwuchs aus Gemeiner Fichte und Bergahorn im Wimbachtal, 20 Jahre nach Borkenkäferbefall (Foto: M.B. Winter). 


\section{Literaturverzeichnis der Kapitel 1, 5 und 6}

Ammer C. 1996a. Impact of ungulates on structure and dynamics of natural regeneration of mixed mountain forests in the Bavarian Alps. For. Ecol. Manage. 88 (1-2): 43-53.

Ammer C. 1996b. Konkurrenz um Licht. Zur Entwicklung der Naturverjüngung im Bergmischwald. Forstliche Forschungsberichte München 158: 1-198.

Ammer C. 1998. Die Fichte in der natürlichen Verjüngung des Bergmischwaldes. Nur eine unter vielen. AFZ-Der Wald 8: 396-399.

Ammer C., Balandier P., Bentsen N.S., Coll L., Löf M. 2011. Forest vegetation management under debate: an introduction. Eur. J. For. Res. 130: 1-5.

Attiwill P.M. 1994. The disturbance of forest ecosystems: the ecological basis for conservative management. For. Ecol. Manage. 63: 247-300.

Aubry S., Magnin F., Bonnet V., Preece R.C. 2005. Multi-scale altitudinal patterns in species richness of land snail communities in south-eastern France. J. Biogeography 32 (6): 985-998.

Bače R., Svoboda M., Pouska V., Janda P., Červenka J. 2012. Natural regeneration in Central-European subalpine spruce forests: Which logs are suitable for seedling recruitment? For. Ecol. Manage. 266: 254-262.

Baier R. 2006. Wurzelentwicklung, Ernährung, Mykorrhizierung und "positive Kleinstandorte" der Fichtenverjüngung (Picea abies [L.] Karst.) auf Schutzwaldstandorten der Bayerischen Kalkalpen. Technische Universität München. Dissertation.

Baier R., Meyer J., Göttlein A. 2007. Regeneration niches of Norway spruce (Picea abies [L.] Karst.) saplings in small canopy gaps in mixed mountain forests of the Bavarian Limestone Alps. Eur. J. For. Res. 126 (1): 11-22.

Barker G.M., Mayhill P.C. 1999. Patterns of diversity and habitat relationships in terrestrial mollusk communities of the Pukeamaru Ecological District, northeastern New Zealand. J. Biogeography 26: 215-238.

Bässler C., Müller J., Cadotte M.W., Heibl C., Bradtka J.H., Thorn S., Halbwachs H. (im Druck). Functional response of lignicolous fungal guilds to bark beetle deforestation. Ecological Indicators.

Bässler C., Müller J., Dziock F., Brandl R. 2010. Effects of resource availability and climate on the diversity of wood-decaying fungi. Journal of Ecology 98 (4): 822-832.

Bässler C., Müller J., Svoboda M., Lepšová A., Hahn C., Holzer H., Pouska V. 2012. Diversity of wood-decaying fungi under different disturbance regimes-a case study from spruce mountain forests. Biodivers. Conserv. 21 (1): 33-49.

Batllori E., Guitérrez E. 2008. Regional tree line dynamics in response to global change in the Pyrenees. Journal of Ecology 96: 1275-1288.

Bauer M.L. 2002. Walddynamik nach Borkenkäferbefall in den Hochlagen des Bayerischen Waldes. TU München. Dissertation.

Bauhus J., Puettmann K.J., Messier C. 2009. Silviculture for old-growth attributes. For. Ecol. Manage. 258: 525537. 
Bayerisches Staatsministerium für Landesentwicklung und Umweltfragen 1987. Verordnung über den Alpenund den Nationalpark Berchtesgaden in der Fassung der Bekanntmachung vom 16. Februar 1987. GVBI 5/1987.

Bebi P., Putallaz J.-M., Fankhauser M., Schmid U., Schwitter R., Gerber W. 2015. Die Schutzfunktion in Windwurfflächen. Swiss Forestry Journal 166 (3): 168-176.

Beer K., Wiepcke T. 2014. Vergleich der natürlichen Wiederbewaldung auf lückigen und flächigen Borkenkäferkalamitätsflächen im Bayerischen Gebirgswald. Hochschule Weihenstephan-Triesdorf. Bachelorarbeit.

Bengtsson J., Nilsson S.G., Franc A., Menozzi P. 2000. Biodiversity, disturbances, ecosystem function and management of European forests. For. Ecol. Manag. 132: 39-50.

Beniston M., Stephenson D.B., Christensen O.B., Ferro C.A., Frei C., Goyette S. et al. 2007. Future extreme events in European climate: an exploration of regional climate model projections. Climatic Change 81: 71-95.

Beudert B., Bässler C., Thorn S., Noss R., Schröder B., Dieffenbach-Fries H. et al. 2015. Bark Beetles Increase Biodiversity While Maintaining Drinking Water Quality. Conserv. Lett.: 8: 272-281.

Bochter R. 1984. Bodenbildung auf Kalk- und Gneisbergsturzblöcken unter subalpinem Fichtenwald. Z. Pflanzenernaehr. Bodenk. 147: 604-613.

Bochter R., Neuerburg W., Zech W. 1981. Humus und Humusschwund im Gebirge. Forschungsbericht 2.

Bohner A., Habeler H., Starlinger F., Svanjak M. 2010. Avalanches keep habitats open and species-rich in the montane and subalpine belt. Eco Mont - Journal on protected mountain areas research 2 (1): 53-57.

Bouget C., Duelli P. 2004. The effects of windthrow on forest insect communities: a literature review. Biolog. Conserv. 118 (3): 281-299.

Brang P. 2001. Resistance and elasticity: promising concepts for the management of protection forests in the European Alps. For. Ecol. Manage. 145: 107-119.

Brang P., Hilfiker S., Wasem U., Schwyzer A., Wohlgemuth T. 2015. Langzeitforschung auf Sturmflächen zeigt Potenzial und Grenzen der Naturverjüngung. Swiss Forestry Journal 166 (3): 147-158.

Brang P., Moran J., Puttonen P., Vyse A. 2003. Regeneration of Picea engelmannii and Abies lasiocarpa in highelevation forests of south-central British Columbia depends on nurse-logs. The Forestry Chronicle 79 (2): 273279.

Brang, Peter 1996. Experimentelle Untersuchungen zur Ansamungsökologie der Fichte im zwischenalpinen Gebirgswald. Beiheft zur Schweizerischen Zeitschrift für Forstwesen 77.

Braun-Blanquet J. 1964. Pflanzensoziologie. 3rd edn. Springer, Wien, New York.

Bruelheide H., Luginbühl U. 2009. Peeking at Ecosystem Stability: Making Use of a Natural Disturbance Experiment to Analyze Resistance and Resilience. Ecology 90 (5): 1314-1325.

Campbell J.L., Donato D.C. 2014. Trait-based approaches to linking vegetation and food webs in early-seral forests of the Pacific Northwest. For. Ecol. Manag. 324: 172-178. 
Christophel D., Spengler S., Schmidt B., Ewald J., Prietzel J. 2013. Customary selective harvesting has considerably decreased organic carbon and nitrogen stocks in forest soils of the Bavarian Limestone Alps. For. Ecol. Manage. 305: 167-176.

Clark P.J., Evans F.C. 1954. Distance to Nearest Neighbor as a Measure of Spatial Relationships in Populations. Ecology 35 (4): 445-453.

Cremer E., Ziegenhagen B., Schulerowitz K., Mengel C., Donges K., Bialozyt R. et al. 2012. Local seed dispersal in European silver fir (Abies alba Mill.): lessons learned from a seed trap experiment. Trees 26 (3): $987-996$.

Diaci J. 2002. Regeneration dynamics in a Norway spruce plantation on a silver fir-beech forest site in the Slovenian Alps. For. Ecol. Manage. 161: 27-38.

Diaci J., Pisek R., Boncina A. 2005. Regeneration in experimental gaps of subalpine Picea abies forest in the Slovenian Alps. Eur. J. For. Res. 124 (1): 29-36.

Donato D.C., Campbell J.L., Franklin J.F. 2012. Multiple successional pathways and precocity in forest development: can some forests be born complex? J. Veg. Sci. 23 (3): 576-584.

Donato D.C., Harvey B.J., Romme W.H., Simard M., Turner M.G. 2013. Bark beetle effects on fuel profiles across a range of stand structures in Douglas-fir forests of Greater Yellowstone. Ecolog. App. 23 (1): 3-20.

Dorren L.K., Berger F., Imeson A.C., Maier B., Rey F. 2004. Integrity, stability and management of protection forests in the European Alps. For. Ecol. Manage. 195 (1-2): 165-176.

Duelli P., Obrist M.K., Wermelinger B. 2002. Windthrow-induced changes in faunistic biodiversity in alpine spruce forests. For. Snow Landsc. Res. 77 (1/2): 117-131.

El Kateb H., Felbermeier B., Schmerbeck J., Ammer C., Mosandl R. 2006. Silviculture and Management of Mixed Mountain Forests in the Bavarian Alps. Silvicultural Experiments 3.

El Kateb H., Schölch M., Mosandl R. 2009. Waldbau-Verfahren für den Bergmischwald Empfehlungen für die Praxis auf wissenschaftlicher Grundlage. LWF aktuell 71: 9-11.

Ellenberg H., Leuschner C. 2010. Vegetation Mitteleuropas mit den Alpen. Ulmer, Stuttgart.

Ewald J. 2002. Multiple controls of understorey plant richness in mountain forests of the Bavarian Alps. phytocoenologia 32 (1): 85-100.

Ewald J., Jehl H., Braun L., Lohberger E. 2011. Die Vegetation des Nationalparks Bayerischer Wald als Ausdruck von Standort und Walddynamik. Tuexenia 31: 9-38.

Falkner G. 1997. Introduction to the malacological excursion to the Berchtesgaden National Park. Heldia 4 (5): 185-187.

Firm D., Nagel T.A., Diaci J. 2009. Disturbance history and dynamics of an old-growth mixed species mountain forest in the Slovenian Alps. For. Ecol. Manage. 257 (9): 1893-1901.

Fischer A., Fischer H.S. 2009. 25 Jahre Vegetationsentwicklung nach Sturmwurf - Eine Dauerbeobachtungsstudie im Bayerischen Wald. Forstarchiv 80: 163-172.

Fischer A., Fischer H.S., Lehnert U. 2012. Avalanches creating high structural and floristic diversity in mountain mixed forests in the Alps. Biodivers. Conserv. 21 (3): 643-654. 
Fischer, Anton (Ed.) 1998. Die Entwicklung von Wald-Biozönosen nach Sturmwurf, Landsberg. ecomed.

Franklin J.F., Spies T.A., van Pelt R., Carey A.B., Thornburgh D.A., Berg D.R. et al. 2002. Disturbances and structural development of natural forest ecosystems with silvicultural implications, using Douglas-fir forests as an example. For. Ecol. Manage. 155 (1-3): 399-423.

Frelich L.E. 2002. Forest dynamics and disturbance regimes Studies from temperate evergreen-decidous forests. Cambridge University Press, Cambridge.

Frich P., Alexander L.V., Della-Marta P., Gleason B., Haylock M., Klein Tank A., Peterson T. 2002. Observed coherent changes in climatic extremes during the second half of the twentieth century. Climate Research 19 : 193-212.

Gadow K.v. 2003. Waldstruktur und Waldwachstum Beiträge zur Vorlesung im Wintersemester 2003 / 2004. Universitätsverlag Göttingen, Göttingen.

Gotelli N.J., Colwell R.K. 2001. Quantifying biodiversity: procedures and pitfalls in the measurement and comparison of species richness. Ecol. Lett. (4): 379-391.

Gray A.N., Spies T.A., Easter M.J. 2002. Microclimatic and soil moisture responses to gap formation in coastal Douglas-fir forests. Can. J. For. Res. 32 (2): 332-343.

Greene D., Johnson E. 1997. Secondary dispersal of tree seeds by snow. J. Ecol. 85: 329-340.

Grimm V., Wissel C. 1997. Babel, or the ecological stability discussions: an inventory and analysis of terminology and a guide for avoiding confusion. Oecologia 109: 323-334.

Halpern C.B., Spies T.A. 1995. Plant species diversity in natural and managed forests of the Pacific Northwest. Ecolog. App. 5 (4): 913-934.

Harmon M., Franklin J.F., Swanson F., Sollins P., Gregory S., Lattin J. et al. 1986. Ecology of coarse woody debis in temperate ecosystems. Adv. Ecol. Res. 15: 133-302.

Hartl-Meier C., Dittmar C., Zang C., Rothe A. 2014. Mountain forest growth response to climate change in the Northern Limestone Alps. Trees 28 (3): 819-829.

Heilmann-Clausen J., Christensen M. 2004. Does size matter? On the importance of various dead wood fractions for fungal diversity in Danish beech forests. For. Ecol. Manage. 201 (1): 105-117.

Hein S., Collet C., Ammer C., Le Goff N., Skovsgaard J.P., Savill P. 2009. A review of growth and stands dynamics of Acer pseudoplatanus L. in Europe: implications for silviculture. Forestry 82 (4): 361-385.

Heinze E., Boch S., Fischer M., Hessenmöller D., Klenk B., Müller J. et al. 2011. Habitat use of large ungulates in northeastern Germany in relation to forest management. For. Ecol. Manage. 261: 288-296.

Holeska J. 2003. Relationship between field-layer vegetation and canopy openings in a Carpathian subalpine spruce forest. Plant Ecology 168: 57-67.

Hollaus A.R. 2012. Evaluation of methods estimating soil loss after coarse-scale disturbances on a montane mixed forest site in the Northern Limestone Alps. BOKU Vienna. Master Thesis. 
Höllerl S. 2009a. Auswirkungen von waldbaulichen Maßnahmen auf die Stabilität (Resistenz und Elastizität) von Fichtenreinbeständen in der Bergmischwaldstufe der Bayerischen Alpen Eine Analyse aus waldbaulichforstökonomischer Sicht. Technische Universität München. Dissertation.

Höllerl S. 2009b. Berücksichtigung finanzieller Aspekte bei waldbaulichen Entscheidungen - eine Fallstudie für reine Fichtenbestände in der Bergmischwaldzone. Forstarchiv 80: 4-14.

Höllerl S., Mosandl R. 2009. Der Bergahorn im Bergmischwald - unübertroffen in seinem Verjüngungspotential. LWF Wissen 62.

Honold A., Oberwinkler F. 1998. Pilze im Totholz. In Anton Fischer (Ed.): Die Entwicklung von Wald-Biozönosen nach Sturmwurf. Landsberg: ecomed: 214-226.

Honold A., Oberwinkler F. 1999. Sukzession saprophytischer und parasitischer Pilze im Fichtentotholz. S.B. Botanisches Institut. Projektbericht.

Huber C. 2005. Long Lasting Nitrate Leaching after Bark Beetle Attack in the Highlands of the Bavarian Forest National Park. J. Environ. Qual. 34 (5): 1772.

Jehl H. 2001. Die Waldentwicklung nach Windwurf in den Hochlagen des Nationalparks Bayerischer Wald In: Nationalparkverwaltung Bayerischer Wald: Waldentwicklung im Bergwald nach Windwurf und Borkenkäferbefall. Nationalparkverwaltung Bayerischer Wald. Wissenschaftliche Reihe 14.

Jonášová M., Prach K. 2004. Central-European mountain spruce (Picea abies (L.) Karst.) forests: regeneration of tree species after a bark beetle outbreak. Ecolog. Engin. 23 (1): 15-27.

Jonášová M., Prach K. 2008. The influence of bark beetles outbreak vs. salvage logging on ground layer vegetation in Central European mountain spruce forests. Biolog.Conserv. 141 (6): 1525-1535.

Jonášová M., Vávrová E., Cudlín P. 2010. Western Carpathian mountain spruce forest after a windthrow: Natural regeneration in cleared and uncleared areas. For. Ecol. Manage. 259 (6): 1127-1134.

Kärvemo S., Rogell B., Schroeder M. 2014. Dynamics of spruce bark beetle infestation spots: Importance of local population size and landscape characteristics after a storm disturbance. For. Ecol. Manage. 334: $232-240$.

Kautz M., Lehmberg K., Schopf R., Lindauer M., Schmid H.P., Wolpert B. et al. 2011. Borkenkäferbefall auf Windwurfflächen: Prozessanalyse für Handlungsoptionen Tätigkeitsbericht 2011. TU München.

Keidel S., Meyer P., Bartsch N. 2008. Regeneration eines naturnahen Fichtenwaldökosystems im Harz nach großflächiger Störung. Forstarchiv 79: 187-196.

Kenter B., Bellmann H., Spelda J., Funke W. 1998. Makrofauna - Zoophage der Streu und der Bodenoberfläche. In Anton Fischer (Ed.): Die Entwicklung von Wald-Biozönosen nach Sturmwurf. Landsberg: ecomed: 259-279.

Klopcic M., Klemen J., Boncina A. 2010. Long-term changes of structure and tree species composition in Dinaric uneven-aged forests: are red deer an important factor? Eur. J. For. Res. 129: 277-288.

Knott H., Bernhart A., Feulner M. 1988. Geschichte der Salinenwälder von Berchtesgaden. Nationalpark Berchtesgaden. Forschungsbericht 12.

Kohlermann L. 1950. Untersuchungen über die Windverbreitung der Früchte und Samen mitteleuropäischer Waldbäume. Forstw. Cbl. 69 (10): 606-624. 
Kohlpaintner M., Göttlein A. 2009. Mit dem Wald verschwindet auch der Humus. Großflächige Störungen in Hochgebirgswäldern führen zu Nährstoffverlusten und beeinträchtigen langfristig die Waldentwicklung. LWF aktuell 71: 22-24.

Kolb E. 2013. Geoökologische Karte Nationalpark Berchtesgaden. Verlag Anton Plenk, Berchtesgaden.

Konnert V. 2004. Standortkarte Nationalpark Berchtesgaden. Nationalpark Berchtesgaden. Forschungsbericht 49.

Konnert V., Siegrist J. 2000. Waldentwicklung im Nationalpark Berchtesgaden von 1983 bis 1997. Nationalpark Berchtesgaden. Forschungsbericht 43.

Kopf A., Funke W. 1998. Xylobionte Arthropoden. In Anton Fischer (Ed.): Die Entwicklung von Wald-Biozönosen nach Sturmwurf. Landsberg: ecomed: 282-291.

Köstler J., Mayer H. 1974. Gutachten über die künftige Behandlung des Waldes im Alpenpark Berchtesgadener Land.

Kraller G., Warscher M., Kunstmann H., Vogl S., Marke T., Strasser U. 2012. Water balance estimation in high Alpine terrain by combining distributed modeling and a neural network approach (Berchtesgaden Alps, Germany). Hydrol. Earth Syst. Sci. 16: 1969-1990.

Kral F., Rall H. 1990. Wälder - Geschichte, Zustand, Planung. Nationalpark Berchtesgaden. Forschungsbericht 20.

Kräuchi N., Brang P., Schönenberger W. 2000. Forests of mountainous regions: gaps in knowledge and research needs. For. Ecol. Manage. 132: 73-82.

Kraus, Daniel; Krumm, Frank (Eds.) 2013. Integrative approaches as an opportunity for the conservation of forest biodiversity. European Forest Institute, Joensuu.

Krehan H., Steyrer 2006. Klimaänderung - Schadorganismen bedrohen unsere Wälder. BFW-Praxisinformation (10): 15-17.

Küffer N., Senn-Irlet B. 2005. Influence of Forest Management on the Species Richness and Composition of Wood-inhabiting Basidiomycetes in Swiss Forests. Biodivers. Conserv. 14 (10): 2419-2435.

Kupferschmid A.D. 2003. Zerfall und Verjüngung eines Schutzwaldes nach dem Absterben der Fichten durch Buchdruckerbefall. GAIA 12 (4): 271-274.

Kupferschmid A.D., Bugmann H. 2005. Effect of microsites, logs and ungulate browsing on Picea abies regeneration in a mountain forest. For. Ecol. Manage. 205 (1-3): 251-265.

Kupferschmid Albisetti A.D. 2003. Succession in a protection forest after Picea abies die-back. Swiss Federal Institute of Technology Zürich. Dissertation.

Kupferschmid Albisetti A.D., Brang P., Schönenberger W., Bugmann H. 2003. Decay of Picea abies snag stands on steep mountain slopes. The Forestry Chronicle 79 (2): 257.

Küßner R. 1997. Sukzessionale Prozesse in Fichtenbeständen (Picea abies) des Osterzgebirges - Möglichkeiten ihrer waldbaulichen Beeinflussung und ihre Bedeutung für einen ökologisch begründeten Waldumbau. Forstw. Cbl. 116: 359-369. 
Kutter M., Gratzer G. 2006. Neue Methoden zur Abschätzung der Samenverbreitungsdistanzen von Waldbäumen am Beispiel der Verbreitung von Picea abies, Abies alba und Fagus sylvatica. Austrian Journal of Forest Science 123 (3): 103-120.

Laiho R., Prescott C.E. 2004. Decay and nutrient dynamics of coarse woody debris in northern coniferous forests: a synthesis. Can. J. For. Res. 34 (4): 763-777.

Lausch A., Fahse L., Heurich M. 2011. Factors affecting the spatio-temporal dispersion of Ips typographus (L.) in Bavarian Forest National Park: A long-term quantitative landscape-level analysis. For. Ecol. Manage. 261 (2): $233-245$.

Lehnert L.W., Bässler C., Brandl R., Burton P.J., Müller J. 2013. Conservation value of forests attacked by bark beetles: Highest number of indicator species is found in early successional stages. J. Nat. Conserv. 21 (2): $97-$ 104.

Leyer I., Wesche K. 2007. Multivariate Statistik in der Ökologie: Eine Einführung. Springer, Heidelberg.

Lonsdale D., Pautasso M., Holdenrieder O. 2008. Wood-decaying fungi in the forest: conservation needs and management options. Eur. J. Forest Res. 127 (1): 1-22.

Lüscher P. 2002. Humus dynamics and changes in rooting patterns in windthrow areas. For. Snow Landsc. Res. 77 (1/2): 49-59.

Magurran A.E. 2004. Measuring Biological Diversity. Blackwell Publishing, Oxford.

Margreth S. 2004. Die Wirkung des Waldes bei Lawinen. Forum für Wissen 2004: 21-28.

McElhinny C., Gibbons P., Brack C., Bauhus J. 2005. Forest and woodland stand structural complexity: Its definition and measurement. For. Ecol. Manage. 218 (1-3): 1-24.

Meddens A.J., Hicke J.A. 2014. Spatial and temporal patterns of Landsat-based detection of tree mortality caused by a mountain pine beetle outbreak in Colorado, USA. For. Ecol. Manage. 322: 78-88.

Meddens A.J., Hicke J.A., Ferguson C.A. 2012. Spatiotemporal patterns of observed bark beetle-caused tree mortality in British Columbia and the western United States. Ecolog. App. 22 (7): 1876-1891.

Meister G. 1969. Überlegungen zur künftigen Betriebsgestaltung im oberbayerischen Hochgebirge. Forstw. Cbl. 88: 202-230.

Meyer P. 2013. Wie schnell werden Wirtschaftswälder zu Urwäldern? AFZ-Der Wald 24: 11-13.

Meyer P., Petersen R. 2003. Regeneration naturnaher Fichtenwälder nach großflächigen Störungen Beispiele aus dem Harz. Forst und Holz 58 (13/14): 401-406.

Moser B., Schütz M., Hindenlang K.E. 2008. Resource selection by roe deer: Are windthrow gaps attractive feeding places? For. Ecol. Manage. 255 (3-4): 1179-1185.

Motta R. 1996. Impact of wild ungulates on forest regeneration and tree composition of mountain forests in the Western Italian Alps. For. Ecol. Manage. 88 (1-2): 93-98.

Mrzljak J., Wiegleb G. 2000. Spider colonization of former brown coal mining areas - time or structure dependent? Landsc.Urban Plan. 51 (2-4): 131-146. 
Müller J., Bässler C., Strätz C., Klöcking B., Brandl R. 2009. Molluscs and Climate Warming in a Low Mountain Range National Park. Malacologia 51 (1): 89-109.

Müller J., Bußler H., Goßner M., Gruppe A., Jarzabek-Müller A., Preis M., Rettelbach T. 2007. Forest edges in the mixed-montane zone of the Bavarian Forest National Park - hot spots of biodiversity. Silva Gabreta 13 (2): 121148.

Müller J., Bußler H., Goßner M., Rettelbach T., Duelli P. 2008. The European spruce bark beetle Ips typographus in a national park: from pest to keystone species. Biodivers. Conserv. 17 (12): 2979-3001.

Müller J., Bütler R. 2010. A review of habitat thresholds for dead wood: a baseline for management recommendations in European forests. Eur. J. For. Res. 129 (6): 981-992.

Müller J., Noss R.F., Bussler H., Brandl R. 2010. Learning from a "benign neglect strategy" in a national park: Response of saproxylic beetles to dead wood accumulation. Biolog.l Conserv. 143 (11): 2559-2569.

Müller J., Strätz C., Hothorn T. 2005. Habitat factors for land snails in European beech forests with a special focus on coarse woody debris. Eur. J. For. Res. 124 (3): 233-242.

Nagel T.A., Levanic T., Diaci J. 2007. A dendroecological reconstruction of disturbance in an old-growth FagusAbies forest in Slovenia. Ann. For. Sci. 64 (8): 891-897.

Nationalpark Berchtesgaden 2001. Nationalparkplan. Nationalpark Berchtesgaden.

Nationalparkverwaltung Berchtesgaden 2003. Die Pflanzenwelt des Nationalparks Berchtesgaden. Berchtesgadener Anzeiger, Berchtesgaden.

Nierhaus-Wunderwald D., Forster B. 2004. Zur Biologie der Buchdruckerarten. WSL - Merkblatt für die Praxis (18).

Odermatt O., Wasem U. 2007. Schutzwirkung von liegen gelassenem Sturmholz. Wald und Holz 88 (7): 32-34.

Otto H.-J. 1994. Waldökologie. Ulmer, Stuttgart.

Overbeck M., Schmidt M. 2012. Modelling infestation risk of Norway spruce by Ips typographus (L.) in the Lower Saxon Harz Mountains (Germany). For. Ecol. Manage. 266: 115-125.

Papaik M.J., Canham C.D. 2006. Species resistance and community response to wind disturbance regimes in northern temperate forests. J. Ecol. 94: 1011-1026.

Pechmann H. von 1932. Beiträge zur Geschichte der Forstwirtschaft im oberbayerischen Hochgebirge. Forstw. Cbl. 54: 605-622, 645-661, 693-709, 721-734.

Pellerin M., Saïd S., Richard E., Hamann J.-L., Dubois-Coli C., Hum P. 2010. Impact of deer on temperate forest vegetation and woody debris as protection of forest regeneration against browsing. For. Ecol. Manage. 260: 429-437.

Peter M., Buée M., Egli S. 2013. Biodiversity of mycorrhizal fungi as a crucial player in forest ecosystem functioning. In: Daniel Kraus, Frank Krumm (Eds.): Integrative approaches as an opportunity for the conservation of forest biodiversity. European Forest Institute, Jonsuu. 
Prietzel J., Ammer C. 2008. Montane Bergmischwälder der Bayerischen Kalkalpen: Reduktion der Schalenwilddichte steigert nicht nur den Verjüngungserfolg, sondern auch die Bondefruchtbarkeit. Allg. Forstu. J.-Ztg. 179 (5/6): 104-112.

Prietzel J., Christophel D. 2014. Organic carbon stocks in forest soils of the German Alps. Geoderma 221-222: 28-39.

Priewasser K. 2013. Factors influencing tree regeneration after windthrwo in Swiss forests. ETH Zürich. Dissertation.

Priewasser K., Brang P., Bachofen H., Bugmann H., Wohlgemuth T. 2013. Impacts of salvage-logging on the status of deadwood after windthrow in Swiss forests. Eur. J. For. Res. 132 (2): 231-240.

Pröll G., Darabant A., Gratzer G., Katzensteiner K. 2015. Unfavourable microsites, competing vegetation and browsing restrict post-disturbance tree regeneration on extreme sites in the Northern Calcareous Alps. Eur. J. For. Res. 134: 293-308.

Puettmann K.J., Ammer C. 2007. Trends in North American and European regeneration research under the ecosystem management paradigm. Eur. J. For. Res. 126 (1): 1-9.

R Core Team 2013. R: A language and environment for statistical computing. R Foundation for Statistical Computing, Vienna, Austria. Online: http://www.R-project.org/.

Rammig A., Fahse L., Bugmann H., Bebi P. 2006. Forest regeneration after disturbance: A modelling study for the Swiss Alps. For. Ecol. Manage. 222 (1-3): 123-136.

Remmert H. 1991. Das Mosaik-Zyklus-Konzept und seine Bedeutung für den Naturschutz - eine Übersicht. Laufener Seminarbeiträge 5: 5-15.

Ricotta C. 2005. Through the jungle of biological diversity. Acta Biotheoretica 53: 29-38.

Rieger A., Schmidberger G., Stelz V., Müller J., Strätz C. 2010. Ökologische Analyse der Molluskenfauna im Nationalpark Bayerischer Wald. Waldökologie, Landschaftsforschung und Naturschutz 9: 65-78.

Ritter E., Dalsgaard L., Einhorn K.S. 2005. Light, temperature and soil moisture regimes following gap formation in a semi-natural beech-dominated forest in Denmark. For. Ecol. Manage. 206 (1-3): 15-33.

Roberts M.R. 2004. Response of the herbaceous layer to natural disturbance in North American forests. Can. J. Bot. 82 (9): 1273-1283.

Saint-Germain M., Drapeau P., M. Buddle C. 2007. Host-use patterns of saproxylic phloeophagous and xylophagous Coleoptera adults and larvae along the decay gradient in standing dead black spruce and aspen. Ecography 30 (6): 737-748.

Salamon J.-A., Scheu S., Schaefer M. 2008. The Collembola community of pure and mixed stands of beech (Fagus sylvatica) and spruce (Picea abies) of different age. Pedobiologia 51 (5-6): 385-396.

Sayer U., Reif A. 1998. Entwicklung der Vegetation im überregionalen Vergleich. In: Anton Fischer (Ed.): Die Entwicklung von Wald-Biozönosen nach Sturmwurf. Landsberg: ecomed: 146-168.

Schelhaas M.-J., Nabuurs G.-J., Schuck A. 2003. Natural disturbances in the European forests in the $19^{\text {th }}$ and $20^{\text {th }}$ centuries. Glob. Change Biol. 9: 1620-1633. 
Seibold S., Brandl R., Buse J., Hothorn T., Schmidl J., Thorn S., Müller J. 2014. Association of extinction risk of saproxylic beetles with ecological degradation of forests in Europe. Conserv. Biol. 29 (2): 382-390.

Seidl R., Schelhaas M.-J., Lexer M.J. 2011. Unraveling the drivers of intensifying forest disturbance regimes in Europe. Glob. Change Biol. 17 (9): 2842-2852.

Seidl R., Schelhaas M.-J., Lindner M., Lexer M.J. 2009. Modeling bark beetle disturbances in a large scale forest scenario model to assess climate change impacts and evaluate adaptive management strategies. Reg. Environ. Change 9: 101-119.

Seidl R., Schelhaas M.-J., Rammer W., Verkerk P.J. 2014. Increasing forest disturbances in Europe and their impact on carbon storage. Nature Climate Change 4: 806-810.

Sippola A.-L., Renvall P. 1999. Wood-decomposing fungi and seed-tree cutting: A 40-year perspective. For. Ecol. Manage. 115 (2-3): 183-201.

Sousa W.P. 1984. The Role of Disturbance in Natural Communities. Annu. Rev. Ecol. Syst. 15: 353-391.

Spandau L. 1988. Angewandte Ökosystemforschung im Nationalpark Berchtesgaden. Nationalpark Berchtesgaden. Forschungsbericht 20.

Spelda J., Müller K., Funke W. 1998. Makrofauna - Saprophage der Streu und der Bodenoberfläche. In: Anton Fischer (Ed.): Die Entwicklung von Wald-Biozönosen nach Sturmwurf. Landsberg: ecomed: 249-258.

Spielvogel S., Prietzel J., Kögel-Knabner I. 2007. Changes of lignin phenols and neutral sugars in different soil types of a high-elevation forest ecosystem 25 years after forest dieback. Soil Biol. Biochem. 39 (2): 655-668.

Stein A., Gerstner K., Kreft H. 2014. Environmental heterogeneity as a universal driver of species richness across taxa, biomes and spatial scales. Ecol. Lett. 17 (7): 866-880.

Storaunet K.O., Rolstad J. 2002. Time since death and fall of Norway spruce logs in old-growth and selectively cut boreal forest. Can. J. For. Res. 32 (10): 1801-1812.

Svoboda M., Janda P., Nagel T.A., Fraver S., Rejzek J., Bače R., Cherubini P. 2012. Disturbance history of an oldgrowth sub-alpine Picea abies stand in the Bohemian Forest, Czech Republic. J. Veg. Sci. 23 (1): 86-97.

Svoboda M., Pouska V. 2008. Structure of a Central-European mountain spruce old-growth forest with respect to historical development. For. Ecol. Manage. 255 (7): 2177-2188.

Swanson M.E., Franklin J.F., Beschta R.L., Crisafulli C.M., DellaSalla D.A., Hutto R.L. et al. 2011. The forgotten stage of forest succession: early successional ecosystems on forest sites. Front. Ecol. Environ. 9: 117-125.

Swanson M.E., Studevant N.M., Campbell J.L., Donato D.C. 2014. Biological associates of early-seral pre-forest in the Pacific Northwest. For. Ecol. Manage. 324: 160-171.

Szewczyk J., Szwagrzyk J. 1996. Tree regeneration on rotten wood and on soil in old-growth stand. Vegetatio 122: $37-46$.

Tews J., Brose U., Grimm V., Tielbörger K., Wichmann M.C., Schwager M., Jeltsch F. 2004. Animal species diversity driven by habitat heterogeneity/diversity: the importance of keystone structures. J. Biogeogr. 31: 7992. 
Thorn S., Bässler C., Brandl R., Burton P.J., Cahall R., et al. (eingereicht). Impacts of salvage logging on biodiversity - a global meta-analysis. Nature communications.

Thorn S., Bässler C., Bußler H., Lindenmayer D.B., Schmidt S., Seibold S. et al. 2016. Bark-scratching of stormfelled trees preserves biodiversity at lower economic costs compared to debarking. For. Ecol. Manage 364: 1016.

Turner M.G. 2010. Disturbance and landscape dynamics in a changing world. Ecology 91 (10): 2833-2849.

Turner M.G., Collins S.L., Lugo A.L., Magnuson J.J., Rupp T.S., Swanson F. 2003. Disturbance Dynamics and Ecological Response: The Contribution of Long-Term Ecological Research. BioScience 53 (1): 46-56.

Turner M.G., Donato D.C., Romme W.H. 2013. Consequences of spatial heterogeneity for ecosystem services in changing forest landscapes: priorities for future research. Landscape Ecol. 28 (6): 1081-1097.

Ulyshen M.D., Klooster W.S., Barrington W.T., Herms D.A. 2011. Impacts of emerald ash borer-induced tree mortality on leaf litter arthropods and exotic earthworms. Pedobiologia 54 (5-6): 261-265.

United Nations 1992. Convention on Biological Diversity. Rio de Janeiro (7/5/1992).

Vierling K., Bässler C., Brandl R., Vierling L., Weiß I., Müller J. 2011. Spinning a laser web: predicting spider distributions using LiDAR. Ecolog. App. 21 (2): 577-588.

Wagner S. 1998. Calibration of grey values of hemispherical photographs for image analysis. Agric. For. Meteorol. 90 (2): 103-117.

Wagner S. 2001. Relative radiance measurements and zenith angle dependent segmentation in hemispherical photography. Agric. For. Meteorol. 107: 103-115.

Wäldchen J., Schulze E.-D., Mund M., Winkler B. 2011. Der Einfluss politischer, rechtlicher und wirtschaftlicher Rahmenbedingungen des 19. Jahrhunderts auf die Bewirtschaftung der Wälder im Hainich-Dün-Gebiet (Nordthüringen). Forstarchiv 82 (2): 35-47.

Walentowski H., Ewald J., Fischer A., Kölling C., Türk W. 2006. Handbuch der natürlichen Waldgesellschaften Bayerns Ein auf geobotanischer Grundlage entwickelter Leitfaden für die Praxis in Forstwirtschaft und Naturschutz. 2nd edition. Geobotanica Verlag, Freising.

Westfall P., Young S. 1993. Resampling-based Multiple Testing. John Wiley \& Sons, New York.

White P.S., Pickett S. 1985. Natural disturbance and patch dynamics: An introduction. In: Pickett S., White P.S., (Eds.). The Ecology of Natural Disturbance and Patch Dynamics. Academic Press, New York.

Whittaker R. 1972. Evolution and measurement of species diversity. Taxon 21 (2/3): 213-251.

Whittaker R., Willis K., Field R. 2001. Scale and species richness: towards a general, hierarchical theory of species diversity. J. Biogeogr. 28 (4): 453-470.

Wild J., Kopecký M., Svoboda M., Zenáhlíková J., Edwards-Jonášová M., Herben T., Vandvik V. 2014. Spatial patterns with memory: tree regeneration after stand-replacing disturbance in Picea abies mountain forests. J. Veg. Sci.: 25 (6): 1327-1340.

Winter M.-B., Becker B. 2015. Walddynamik im Nationalpark Berchtesgaden. Schriften des Nationalparks Gesäuse 12: 106-111. 
Wohlgemuth T., Kramer K. 2015. Waldverjüngung und Totholz in Sturmflächen 10 Jahre nach Lothar und 20 Jahre nach Vivian. Swiss Forestry Journal 166 (3): 135-146.

Wohlgemuth T., Kull P., Wüthrich H. 2002. Disturbance of microsites and early tree regeneration after windthrow in Swiss mountain forests due to the winter storm Vivian 1990. For. Snow Landsc. Res. 77 (1/2): 1747.

Zenner E.K. 2000. Do residual trees increase structural complexity in Pacific Northwest coniferous forests? Ecolog. App. 10 (3): 800-810.

Zeppenfeld T., Svoboda M., DeRose R.J., Heurich M., Müller J., Čížková P. et al. 2015. Response of mountain Picea abies forests to stand-replacing bark beetle outbreaks: neighbourhood effects lead to self-replacement. J. Appl. Ecol. 52 (5): 1402-1411.

Zhongsheng H., Jinfu L., Caiting W., Shiqun Z., Wei H., Songjin S., Chengzhen W. 2012. Effects of forest gaps on some microclimate variables in Castanopsis kawakamii natural forest. J. Mt. Sci. 9 (5): 706-714.

Zielonka T. 2006. When does dead wood turn into a substrate for spruce replacement? J. Veg. Sci. 17: 739-746. 


\section{Tabellenverzeichnis}

Tabelle 1.1 Kategorien der Diversität in Abhängigkeit des Erhebungsmaßstabs

Tabelle 1.2 Wesentliche Attribute der Probeflächen der Fichtenaltbestände

Tabelle 1.3 Wesentliche Attribute der Probeflächen der beginnenden Sukzession

Tabelle 1.4 Wesentliche Attribute der Probeflächen der fortschreitenden Sukzession

Tabelle 1.5 Wesentliche Attribute der Probeflächen auf Störungsflächen > 1 ha

Tabelle 2.1 Mittelwert der Strukturattribute der drei Sukzessionsstadien

Tabelle 2.2 Entfernung der nächsten Samenbäume der sieben Hauptbaumarten

Tabelle 2.3 Mittlere Jungwuchsdichten und Baumartenanteile des Aufwuchses

Tabelle 3.1 Untersuchte Artengruppen innerhalb der funktionellen Gruppen

Tabelle 3.2 Median der strukturellen Attribute der drei Entwicklungsstadien

Tabelle 3.3 Rang-Korrelationsmatrix der Struktur-, Pflanzen-, Tier-, und Pilzattribute

Tabelle 3.4 Affinität einzelner Arten zu den Entwicklungsstadien (Indikatorarten-Analyse)

Tabelle 4.1 Erfasste Umweltparameter und deren Korrelation mit der Artenzusammensetzung

Tabelle 4.2 Alpha- und Beta-Diversität der Strukturen, Pflanzen, Pilze und Käfer in den Sukzessionsstadien

Tabelle 4.S4. Mittelwerte und Beta-Diversität funktioneller Merkmale von Pflanzen, Pilzen und Käfern

Tabelle 4.S5. Artenliste der Gefäßpflanzen und deren Stetigkeit

Tabelle 4.S6. Artenliste der totholzbesiedelnden Pilze und deren Stetigkeit

Tabelle 4.S7. Artenliste der totholzbesiedelnden Käfer und deren Stetigkeit

Tabelle 4.S11. Beobachtete und geschätzte Artenzahlen von Pflanzen, Pilzen und Käfern

Tabelle 5.1 Samenbäumen der Fichte in verschiedenen Entfernungsklassen

Tabelle 5.2 Mittlere Jungwuchsdichten und Baumartenanteile an verschiedenen Lückenpositionen

Tabelle 5.3 Mittlere Jungwuchsdichten und Baumartenanteile auf Flächen ohne/mit Räumung \& Pflanzung 


\section{Abbildungsverzeichnis}

Abb. 8.1 Modelkonzept des Störungseinflusses auf Waldökosysteme 9

Abb. 1.9 Einflussparameter natürlicher Störungen auf die Artenzusammensetzung von Wäldern 10

Abb. 1.10 Lage des Nationalparks Berchtesgaden 13

Abb. 1.11 Zonierung des Nationalparks Berchtesgaden 16

Abb. 1.12 Konzept der unechten Zeitreihe und des Untersuchungsdesigns 20

Abb. 1.13 Lage der Probeflächen im Nationalpark 21

Abb. 1.14 Probeflächendesign 22

Abb. 2.1 Karte des Nationalparks Berchtesgaden mit Verbreitung des Borkenkäferbefalls 40

Abb. 2.2 Unechte Zeitreihe der Waldentwicklung vor und nach Absterben des Fichtenbestandes 41

Abb. 2.3 Häufigkeitsverteilung der Flächenausdehnung des Borkenkäferbefalls 46

Abb. 2.4 Verfügbarkeit bestimmter Mikrostandorte und deren Nutzung als Keimstandort 49

Abb. 2.5 Jungwuchsdichten und mittlerer Anteil mit Terminaltriebverbiss 51

Abb. 2.6 NMDS Ordination des Jungwuchses und relevanter Umweltparameter 54

Abb. 2.7 Mittlere Verjüngungsraten 55

Abb. 3.1 Schlüsselstrukturen und Auswirkungen auf verschiedene funktionelle Gruppen 75

Abb. 3.2 Untersuchungsgebiet mit Waldfläche und Lage der Probeflächen 77

Abb. 3.3 Artenzahlen der funktionellen Artengruppen in den drei Entwicklungsstadien 83

Abb. 3.4 Arten-Akkumulationskurven von Tieren, Pilzen und Pflanzen 84

Abb. 4.1 Erwartete Veränderungen der Beta-Diversität von Strukturen, Pflanzen, Pilzen und Käfern 108

Abb. 4.2 Topographische Karte des Nationalparks Berchtesgaden mit der Lage der Probeflächen 110

Abb. 4.3 NMDS-Ordination der Pflanzen, Pilze und Käfer 119

Abb. 4.S8. Phylogenie der Artengemeinschaft der Gefäßpflanzen. 146

Abb. 4.S9. Phylogenie der Artengemeinschaft der totholzbesiedelnden Pilze 147

Abb. 4.S10. Phylogenie der Artengemeinschaft der totholzbesiedelnden Käfer 148

Abb. 5.1 Mittlere Humusmächtigkeiten an verschiedenen Lückenpositionen 153

Abb. 5.2 Digitalisierte Borkenkäfer-Befallsflächen > 1 ha über dem CIR-Luftbild von 2012154

Abb. 5.3 Mittlere Anteile an direkter Strahlung an verschiedenen Lückenpositionen 155

Abb. 5.4 Jungwuchsdichten an verschiedenen Lückenpositionen 156

Abb. 5.5 Höhenzuwachs der Gemeinen Fichte im Jahr 2011 an verschiedenen Lückenpositionen 158

Abb. 5.6 Standort-/Bestandescharakteristika von Befallsflächen ohne und mit Räumung und Pflanzung 160

Abb. 5.7 Vergleich der Verjüngungsdichten zwischen Befallsflächen ohne und mit Räumung und Pflanzung 161

Abb. 5.8 Anteile der Hauptbaumarten auf den Probeflächen ohne und mit Räumung und Pflanzung 162

Abb. 5.9 Artenzahlen auf den Probeflächen ohne und mit Räumung und Pflanzung 163

Abb. 5.10 Venn-Diagramm der untersuchten funktionellen Gruppen 164 


\section{Danksagung}

Die vorliegende Arbeit wäre ohne die Unterstützung zahlreicher Personen nicht möglich gewesen.

Dr. Roland Baier hat das Projekt aufgrund aktuellen Anlasses im Nationalpark initiiert. Seine Begeisterung für die natürlichen Prozesse im Bergwald, sein unkomplizierter Pragmatismus bei Entscheidungen und seine wohlwollende Unterstützung haben diese Arbeit nicht nur ermöglicht, sondern die Zeit in der Nationalparkverwaltung in Berchtesgaden auch zu einer sehr wertvollen Zeit gemacht.

Prof. Dr. Christian Ammer übernahm erfreulicherweise die universitäre Betreuung des Projekts. Für seine immer zeitnahe, konstruktive und fachlich fundierte Unterstützung und sein großes Vertrauen in diese Arbeit, auch über die räumliche Distanz zwischen Göttingen und Berchtesgaden, bin ich ihm sehr dankbar.

Darüber hinaus danke ich Prof. Dr. Jörg Müller für wertvolle Unterstützung bei der Organisation und Auswertung des Biodiversitätsaspektes der Waldentwicklung, bei statistischen Fragen und als sehr forderndes, aber meist motivierendes Beispiel für effektives wissenschaftliches Arbeiten.

Auch von unbeteiligten Wissenschaftlern wurde ich fachlich unterstützt: Prof. Dr. Jörg Ewald und Prof. Dr. Manfred Schölch (Hochschule Weihenstephan-Triesdorf), Prof. Dr. Wolfgang Schmidt (Georg-August-Universität Göttingen), Prof. Dr. Hanno Schaefer (Technische Universität München), Dr. Markus Bernhardt-Römermann (Friedrich-Schiller Universität Jena), Dr. Hans-Gerd Michiels (Forstliche Versuchs- und Forschungsanstalt Baden-Württemberg), Dr. Daniel Donato (Washington State Departments of Natural Resources) und Prof. Dr. Eric Zenner (Pennsylvania State University).

Ohne die tatkräftige Mithilfe vieler geländegängiger Studenten wären die umfangreichen Aufnahmen für dieses Projekt aber nicht zu bewältigen gewesen. Daher sei hier an dieser Stelle Roman Juríček, Lisa Schubert, Mona Reiss, Saskia Kolb ( + ), Tobias Wiepcke, Xaver Boigs, Stephan Steinbauer, Dani Findlay, Raluca Herascu und Karin Beer für ihre motivierte Mitarbeit und Ausdauer bei Regen, im Steilhang, und bei unzählbar scheinenden Naturverjüngungsbeständen oder Aaskäfermengen in Bodenfallen herzlich gedankt! Thomas Hackinger, Anton Specht, Xaver Boigs, Karin Beer, Tobias Wiepcke und Petra Demmel haben darüber hinaus ihre Bachelorarbeiten im Rahmen des Projekts geschrieben und durch ihre Auswertungen viele wertvolle Denkanstöße für diese Arbeit gegeben.

Fritz Eder hat wesentlich zur Vegetationskartierung im Gelände beigetragen. Dafür, und für seine Begeisterung für die belebten und unbelebten Elemente der Berchtesgadener Alpen danke ich ihm herzlich. Dr. Wolfang Lippert von der Botanischen Staatssammlung München übernahm die 
Bestimmung kritischer Herbarbelege. Darüber hinaus danke ich Hans Maltan, der alle Probeflächen professionell fotografisch erfasst hat und das Fotomonitoring und die Betreuung der Temperaturlogger auch in den kommenden Jahren weiterführen wird. Bernd Becker war mit seiner Erfahrung von der Waldinventur nicht nur eine unschätzbare Hilfe bei Organisations-, Material- und Logistikproblemen im Nationalpark, sondern hat auch als Büro- und Fachkollege vor Ort wertvolle Unterstützung bei Darstellungs- und Formulierungsfragen geleistet. Doris Huber hat hilfreiche Hinweise bei der Auswertung der Vegetationsdaten eingebracht. Anita Bacher und Brigitte Renoth bin ich für die herzliche Aufnahme in der Abteilung Parkmanagement der Nationalparkverwaltung sehr dankbar. Silke Hartman hat an der Georg-August-Universität Göttingen geduldig die bürokratische Organisation des Projekts begleitet.

Die zahlreichen faunistischen Proben der Barber- und Fensterfallen 2012 wurden von Theo Blick (Arachnida: Araneae), Martin Goßner (Heteroptera), Christoph Muster (Arachnida: Opiliones \& Pseudoscorpiones), Jörg Salamon (Collembola), Christian Strätz (Mollusca), Alexander Szallies (Coleoptera) und Johannes Voith (Aculeata) auf Artniveau bestimmt. Die bislang noch nicht abschließend ausgewerteten Nachtfalterproben (Lepitoptera) aus Lichtfallenfängen wurden von Alfred Haslberger bestimmt. Peter Karasch und Andreas Gminder haben 2013 die Kartierung der Totholzpilze im Gelände übernommen.

Für Solidarität bei R-Problemen, Unterstützung bei der Auswertung und vielen wertvollen fachlichen Diskussionen danke ich Sebastian Seibold, Simon Thorn und Alois Simon.

Schließlich danke ich neben den Revierleitern Werner Vogel, Hans Neubauer und Matthias Hofbeck, den vielen weiteren, hier nicht namentlich erwähnten Kollegen der Nationalparkverwaltung Berchtesgaden, die das Projekt mit Fahrten über den Königssee und Obersee, mit Material, Orts- und EDV-Kenntnis unkompliziert und herzlich unterstützt haben.

Meine Familie, Freunde und Mitbewohner haben das Entstehen dieser Arbeit in den letzten Jahren interessiert begleitet und auch immer wieder durch kritische Gegenfragen unterstützt. Besonders Kommasetzung und deutsche und englische Grammatik wurden in den letzten Wochen durch meine Mutter Hildegund Winter und durch meinen Partner Steffen Endreß wesentlich verbessert. Für die Begleitung und Unterstützung bin ich ihnen allen, ebenso wie für gemeinsame Berg- und Skitouren auch oberhalb der Waldgrenze der Berchtesgadener Alpen, herzlich dankbar.

Das Forschungsprojekt Natürliche Waldentwicklung nach Borkenkäferbefall im Nationalpark Berchtesgaden (Laufzeit 01.01.2012 bis 28.02.2015), in dessen Rahmen diese Arbeit entstanden ist, wäre ohne die Finanzierung durch das Bayerische Staatsministerium für Umwelt und Verbraucherschutz (StMUV) nicht möglich gewesen. 


\section{Publikationsliste}

\section{Artikel in Zeitschriften mit Gutachtersystem}

Winter M.-B., Bässler C., Bernhardt-Römermann M., Krah F.-S., Schaefer H., Seibold S., Müller J. (eingereicht). High spatial heterogeneity of early-seral forest ecosystems affects diversity of producers, consumers and decomposers differently. J. Veg. Science.

Thorn S., Bässler C., Brandl R., Burton P.J., (...), Winter M.-B., Zmihorski M., Müller J. (eingereicht). Impacts of salvage logging on biodiversity - a global meta-analysis. Nat. Commun.

Winter M.-B., Baier R., Ammer C. 2015. Regeneration dynamics and resilience of unmanaged mountain forests in the Northern Limestone Alps following bark beetle-induced spruce dieback. Eur. J. For. Res. 134: 949-968.

Winter M.-B., Ammer C., Baier R., Donato D.C., Seibold S., Müller J. 2015. Multi-taxon alpha diversity following severe bark beetle disturbance: Evaluating multi-decade persistence of a diverse early-seral phase. For. Ecol. Manage. 338: 32-45.

Winter M.-B., Wolff B., Gottschling H., Cherubini P. 2009. The impact of climate on radial growth and nut production of Persian Walnut (Juglans regia L.) in Southern Kyrgyzstan. Eur. J. For. Res. 128 (6): 531-542.

Sonstige wissenschaftliche Artikel

Winter M.-B., Becker B. 2015. Walddynamik im Nationalpark Berchtesgaden. Schriften des Nationalparks Gesäuse 12: 106-111.

Winter M.-B., Eder F. 2014. Bemerkenswerter Wiederfund von Botrychium virginianum (L.) Sw. subsp. europaeum (Ångst.) Jáv. im Nationalpark Berchtesgaden. Berichte der Bayerischen Botanischen Gesellschaft 84: 135-137.

Thorn S., Winter M.-B., Bussler H., Seibold S. 2014. Forstdiensthütten sind wichtige Quartiere [für Fledermäuse] im Bergwald. AFZ-Der Wald 09/2014: 31-32.

Winter M.-B., Schindler H. 2012. Waldquellenmonitoring im Naturpark Pfälzerwald. Wissenschaftliches Jahrbuch des grenzüberschreitenden Biosphärenreservates Pfälzerwald /Nordvogesen 16: 182-212.

Winter M.-B., Wolff B. 2008. Zum Wachstum der Walnuss-Frucht-Wälder in Süd-Kirgistan unter Berücksichtigung verschiedener Standortsfaktoren und Bewirtschaftungsformen. Beiträge zur Jahrestagung 2008, Deutscher Verband Forstlicher Forschungsanstalten, Sektion Ertragskunde. 


\section{Curriculum Vitae - Maria-Barbara Winter}

Geboren am 18. April 1984 in Heilbronn am Neckar

\section{Arbeitserfahrung}

seit $04 / 2015$

$01 / 2012-02 / 2015$

$12 / 2010-12 / 2011$

$11 / 2009-11 / 2010$

$02 / 2009-07 / 2009$

$08 / 2006-02 / 2007$

$09 / 2003-08 / 2004$
Forstliche Versuchs- und Forschungsanstalt Baden-Württemberg (FVA), Freiburg

Abteilung Waldnaturschutz, Arbeitsbereich Waldpflanzenökologie

Wissenschaftliche Mitarbeiterin, Konzeption Artenschutz im Staatswald,

Vegetationsmonitoring in Waldschutzgebieten.

\section{Georg-August-Universität Göttingen,}

Abteilung Waldbau und Waldökologie der gemäßigten Zonen

Wissenschaftliche Mitarbeiterin, Projektbearbeitung „Natürliche Waldentwicklung nach Borkenkäferbefall im Nationalpark Berchtesgaden“

\section{Landesforsten Rheinland-Pfalz, FAWF Trippstadt}

Sachbearbeitung \& Forschungskoordination am Reinland-Pfalz Kompetenzzentrum für Klimawandelfolgen an der Forschungsanstalt für Waldökologie und Forstwirtschaft (FAWF)

Landesforsten Rheinland-Pfalz, Forstamt Wasgau, Dahn

Vorbereitungsdienst für den gehobenen Forstdienst \& Gebietsförsterin

Universität für Bodenkultur Wien, Österreich

Institut für Waldbau: Assistenz bei Exkursionen \& Übungen.

Institut für Holzforschung: Jahrringanalyse für Provinienzversuche

\section{Fachhochschule Eberswalde, Fachbereich Forstwirtschaft}

Assistenz bei Vorlesungen und Übungen im Fach Waldmesslehre und Forstinventur; Inventarisierung, Verwaltung und Wartung der Geräte

\section{Ökologische Schutzstation Steinhuder Meer, Wunstorf}

Freiwilliges Ökologisches Jahr; Ornithologische und botanische Kartierungen, Renaturierung von Hochmoor und Feuchtgebietsflächen, Umweltbildung, Öffentlichkeitsarbeit

\section{Ausbildung}

seit 04/2012

$08 / 2007-07 / 2009$

$09 / 2004-08 / 2007$

$09 / 2000-07 / 2003$
Promotion „Forstwissenschaften und Waldökologie“ Georg-August-Universität Göttingen

Master of Science „European Forestry” Double degree Erasmus Mundus Studium an der Universität Joensuu (FIN) und der Universität für Bodenkultur Wien (A)

Bachelor of Science „International Forest Ecosystem Management” Fachhochschule Eberswalde, Fachbereich Forstwirtschaft

Allgemeiner Hochschulabschluss

Agrarwissenschaftliches Gymnasium, Öhringen 